UNIVERSIDADE DE SÃO PAULO

PROGRAMA DE INTEGRAÇÃO DA AMÉRICA LATINA

LUÍS ALEXANDRE CARTA WINTER

O MERCOSUL E O SISTEMA PRESIDENCIALISTA 
LUÍS ALEXANDRE CARTA WINTER

\section{O MERCOSUL E O SISTEMA PRESIDENCIALISTA}

Tese apresentada ao Programa de Integração da América Latina para obtenção do título de Doutor em Integração.

Área de Concentração: Integração da América Latina

Orientadora: Profa. Dra. Araminta Mercadante 
AUTORIZO A REPRODUÇÃO E DIVULGAÇÃO TOTAL OU PARCIAL DESTE TRABALHO, POR QUALQUER MEIO CONVENCIONAL OU ELETRÔNICO, PARA FINS DE ESTUDO E PESQUISA, DESDE QUE CITADA A FONTE.

Catalogação na Publicação

Serviço de Documentação do PROLAM

Programa de Integração da América Latina da Universidade de São Paulo

WINTER, Luís Alexandre Carta.

O MERCOSUL e o Sistema Presidencialista; orientadora Araminta de Azevedo Mercadante. - São Paulo, 2008.

$155 \mathrm{f}$. Latina.

Tese (Doutorado - Programa de Pós-Graduação em Integração da América Área de Concentração: Integração da América Latina - Programa de Integração da América Latina - PROLAM.

1. MERCOSUL. 2. Blocos Econômicos. 3. Presidencialismo. 4. Integração Econômica Internacional. I. Título. 
FOLHA DE APROVAÇÃO

\author{
Luís Alexandre Carta Winter \\ O MERCOSUL E O SISTEMA PRESIDENCIALISTA
}

Tese apresentada ao Programa de Pós-Graduação em Integração da América Latina - PROLAM, da Universidade de São Paulo, para obtenção do título de Doutor.

Área de Concentração: Integração da América Latina

Aprovado em:

BANCA EXAMINADORA

Prof. Dr. Umberto Celli Júnior

Instituição: Universidade de São Paulo - FD/PROLAM

Assinatura:

Prof $^{a}$. Dra ${ }^{a}$. Maria Cristina Caciamalli

Instituição: Universidade de São Paulo - FEA/PROLAM

Assinatura:

Prof. Dr. José Carlos de Magalhães

Instituição: Universidade de São Paulo - Faculdde de Direito

Assinatura:

Prof. Dr. Ricardo Seitenfuss

Instituição: Universidade Federal de Santa Maria (UFSM) e FADISMA

Assinatura:

Prof. Dr. Luiz Fernando Coelho

Instituição: Universidade Federal do Paraná (UFPR, Universidade Estadual de Umuarama

Assinatura: 
À Célia, nome da minha rosa. 


\section{AGRADECIMENTOS}

Aos meus filhos e meus pais, fontes de inspiração, ajuda, correção e traduções.

À minha orientadora Dra. Araminta de Azevedo Mercadante, que se arriscou aceitando esta empreitada. Meu eterno agradecimento.

Ao Prof. Dr. José Carlos de Magalhães, que vez valer cada segundo de suas iluminadas aulas.

Ao PROLAM e sua extraordinária proposta: a integração da América Latina. 


\section{RESUMO}

Nesta tese trabalha-se a origem e o histórico dos Blocos Econômicos em geral e do MERCOSUL em particular e, dentro do MERCOSUL, são esmiuçados o Tratado de Assunção, o Protocolo de Ouro Preto e a atual estrutura institucional do MERCOSUL, bem como o processo de internalização das normas ali existentes. Também são traçadas, dentro do sistema presidencialista, as condições históricas e sociais que o favoreceram, a história do presidencialismo dentro dos Estados-Partes originários do MERCOSUL, além de se fazer uma análise da atuação do Poder Executivo, nesses Estados. A seguir, reunindo MERCOSUL e presidencialismo, é investigada a integração como política de governo, onde se verifica a interferência do sistema presidencialista nas decisões do MERCOSUL, tanto no aspecto de união aduaneira, como voltadas para a criação de um mercado comum, com uma análise das dificuldades e implantação desse mercado. Na conclusão, com a criação do mercado comum, analisa-se a relação que se estabelece entre esse mercado e o sistema presidencialista.

Palavras-chave: MERCOSUL; blocos econômicos; presidencialismo; integração econômica internacional. 


\begin{abstract}
In this thesis work is the origin and history of economic blocks in general and of MERCOSUL in particular and within MERCOSUL, are detailed the Treaty of Asuncion, the Ouro Preto Protocol, and the current institutional structure of MERCOSUL, as well as the process of internalizing standards there. They are also outlined, in the presidential system, the historical and social conditions that favored the history of presidential within the States Parties from the MERCOSUL, in addition to doing an analysis of the performance of the executive power, in those States. Then, joining MERCOSUL and presidentialism, it investigated how the integration policy of government, where there is the interference of the presidential system in the decisions of MERCOSUL, both in the aspect of the customs union, as directed to the creation of a common market, with an analysis of the difficulties in deployment of this market. In conclusion, with the creation of the common market, analyses are the relationship that is established between this market and the presidential system.
\end{abstract}

Keywords: MERCOSUL; economical blocks; presidentialism; international economical integration. 


\section{RESUMEN}

En esta tesis se trabaja el origen y el histórico de los Bloques Económicos en general y del MERCOSUR en particular $y$, dentro del MERCOSUR, son desmenuzados el Tratado de Asunción, el Protocolo de Ouro Preto y la actual estructura institucional del MERCOSUR, bien como el proceso de internalización de las normas allí existentes. También son trazadas, dentro del sistema presidencialista, las condiciones históricas y sociales que lo favorecieron, la historia del presidencialismo dentro de los Estados-Partes originarios del MERCOSUR, además de hacerse un análisis de la actuación del poder ejecutivo, en esos Estados. A continuación, reuniendo MERCOSUR y presidencialismo, es investigada la integración como política de gobierno, donde se verifica la interferencia del sistema presidencialista en las decisiones del MERCOSUR, tanto en el aspecto de unión aduanera, como dirigidas para la creación de un mercado común, con un análisis de las dificultades e implantación de ese mercado. En la conclusión, con la creación del mercado común, se analiza la relación que se establece entre ese mercado y el sistema presidencialista.

Palabras-clave: MERCOSUR; bloques económicos; presidencialism; integración económica internacional. 


\section{SUMÁRIO}

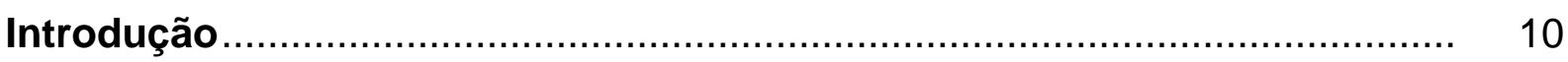

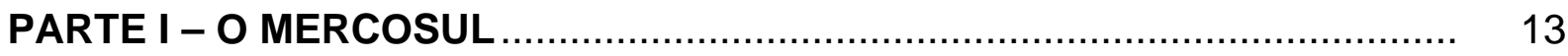

CAPÍTULO - Os Blocos Econômicos........................................................ 22

a) zona de preferências alfandegárias .................................................... 23

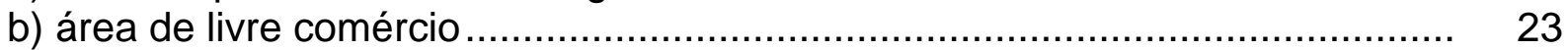

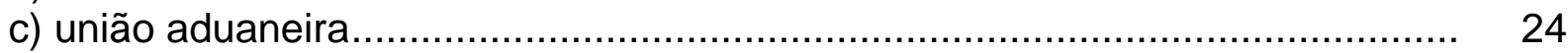

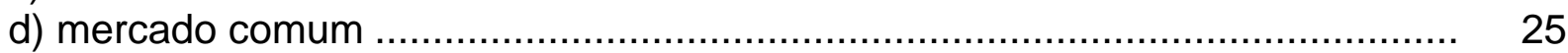

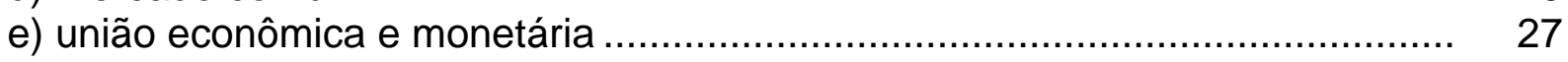

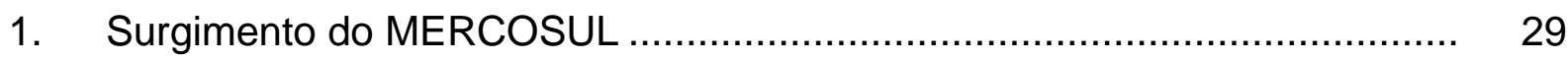

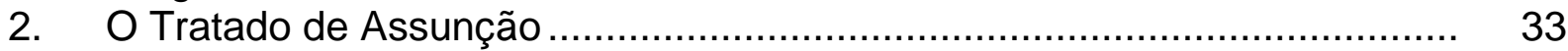

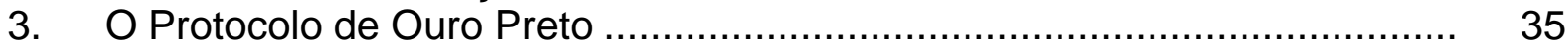

4. A atual estrutura institucional do MERCOSUL ................................... 37

CAPÍTULO II - O processo de internalização das normas ............................ 43

PARTE II - O SISTEMA PRESIDENCIALISTA ........................................ 49

CAPÍTULO III - Condições históricas e sociais para o surgimento do sistema.... 51

CAPÍTULO IV - O presidencialismo nos países do MERCOSUL .................... 66

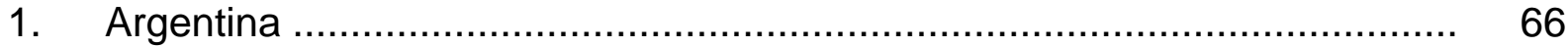

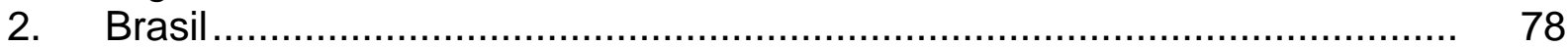

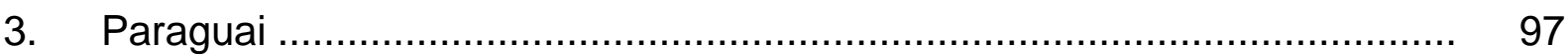

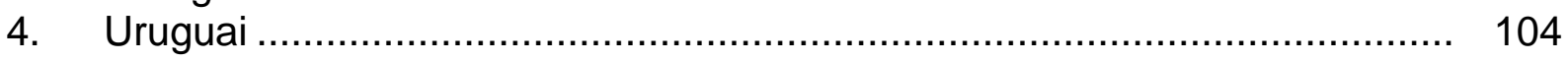

5. O Poder Executivo, o sistema presidencialista e a Constituição................ 111

PARTE III - A INTEGRAÇÃO COMO POLÍTICA DE GOVERNO .................. 115

CAPÍTULO V - A interferência do sistema Presidencialista nas decisões de um mercado comum para o MERCOSUL ............................ 118

CAPÍTULO VI - O Mercado Comum e o Presidencialismo ........................... 126

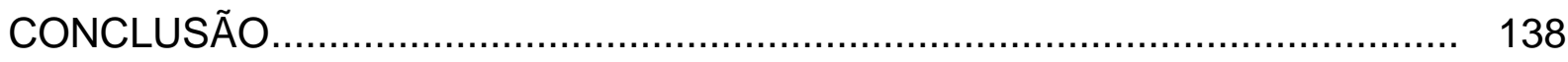

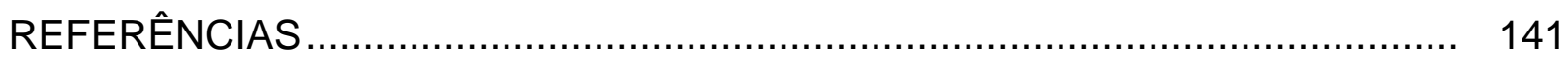




\section{INTRODUÇÃO}

Pode o MERCOSUL vir a se tornar um mercado comum, dentro de um sistema presidencialista? E, implantado o mercado comum, como este pode existir, dentro de um bloco que adota, unicamente, o sistema presidencialista? Questões semelhantes que encerram mecanismos diferentes. A primeira, fiel ao objetivo-fim do MERCOSUL, que é se tornar um mercado comum. A segunda, criado o mercado comum, como ficarão as relações de poder e como isto se refletirá em um bloco que adota, unicamente, o sistema presidencialista.

A busca pela resposta a estas questões é o fio condutor. A primeira questão foi, nominalmente, objeto da problematização da dissertação de mestrado, e, à época, com o MERCOSUL sendo um pouco mais do que perspectiva, a análise acabou por limitar-se a apenas à integração, fração menor, portanto, da primeira questão; assim, muitos aspectos que mereciam uma melhor investigação foram deixados de lado. No entanto, o que foi desenvolvido serviu como precioso substrato para o presente trabalho.

Estas lacunas foram agora exploradas, na expectativa de responder a ambas as questões, reconhecendo-se que a segunda, e objeto desta tese, encerre em si mesma uma hipótese ainda não verificável, já que o MERCOSUL ainda não é um mercado comum, e, portanto, não há como se saber, in concreto, como se portarão os Estados-Partes do Bloco, todos presidencialistas, dentro do mercado comum. Mas a concreção, como bem lembra Luis Fernando Coelho, não consiste na 
referência constante a situações reais ${ }^{1}$, pois a regra continuará como um esquema lógico-formal.

Para responder às questões, utilizando-se de um método de abordagem descritivo-dedutivo, o trabalho foi dividido em três partes e em seis capítulos.

A primeira parte, dentro de uma contextualização, analisa-se o surgimento dos blocos econômicos e, dentro deles, o MERCOSUL, título da primeira parte. No primeiro capítulo, estudam-se os blocos econômicos e suas fases, subdividido em quatro seções. Na primeira, estuda-se o surgimento do MERCOSUL; na segunda analisa-se o Tratado de Assunção; na terceira, o Protocolo de Ouro Preto, e, na quarta, a atual estrutura institucional do MERCOSUL. No segundo capítulo, o objeto é o processo de internalização das normas.

Na segunda parte, é abordado o sistema presidencialista, com um capítulo que trabalha suas condições históricas e sociais para o surgimento do sistema e outro capítulo que estuda o presidencialismo nos países do MERCOSUL, englobando cada um dos Estados-Partes fundadores, além de um estudo integrando o Poder Executivo, o sistema presidencialista e a Constituição. Optou-se aqui por delimitar o período entre a criação do Bloco até o mês de janeiro de 2008, razão pela qual o estudo não abarcou a Venezuela, mas, independentemente disso, este

1 Luís Fernando Coelho discorre que "abstração significa exclusão de todo conteúdo material e de toda referência a situações vividas, o que se opõe à juridicidade; [...] A concreção não consiste na referência constante a situações reais, pois a regra continuará sendo neste caso mero esquema lógico-formal, integralizador de casos por uma técnica de subsunção; ela deve ser concebida como estrutura, onde a relação de condutas se confunde com o comando expressado, em contínua atualização em virtude de sua própria natureza e como exigência da relação vital que lhe é imanente; todos os fatores que entram na consideração do direito, tudo o que pode revestir a forma da juridicidade, estão contidos na própria regra, a qual, ao absorve-los, ao mesmo tempo que os transforma em algo jurídico, os faz desaparecer como coisas não jurídicas, isto é, configuram a norma jurídica e são por ela configurados. A atuação da regra, em função da própria vida humano-social, configura o movimento do objeto norma jurídica". (COELHO, Luís Fernando. Lógica Jurídica e Interpretação das Leis. 2. ed. Rio de Janeiro: Forense, 1981. p. 25) 
fato em nada afetaria o estudo em si, já que também ela, a Venezuela, adota o sistema presidencialista.

Na terceira parte objetivou-se traçar o liame entre os propósitos-fim do bloco, com o sistema adotado pelos Estados-Partes, sob o título "A integração como Política de Governo". Também aqui, dividiu-se em dois capítulos: o capítulo cinco, que trabalha com a interferência do sistema presidencialista nas decisões do MERCOSUL, e o seguinte, versando sobre o mercado comum e o presidencialismo, respondendo à primeira questão.

A resposta à segunda questão encontra-se na conclusão, onde se demonstra a possibilidade de, implantado o mercado comum, este conviver com o sistema presidencialista. 
PRIMEIRA PARTE

\section{O MERCOSUL}

\section{CONTEXTUALIZAÇÃO}

Ao término da Segunda Guerra Mundial, tornou-se evidente a necessidade de os países vencedores criarem mecanismos para evitar a repetição de um conflito que ceifou mais de cinqüenta milhões de pessoas²; surgem, em conseqüência, a ONU, o FMI, o Banco Mundial, o GATT, como também o próprio Plano Marshall, este, para a reconstrução da Europa. Esses fatores fizeram com que as economias nacionais passassem a interagir, aliados à expansão industrial dos países desenvolvidos, principalmente dos Estados Unidos ${ }^{3}$.

Ainda como resultado da Segunda Guerra Mundial, há dois pólos de poder: o ocidental, liderado pelos Estados Unidos, onde vigorava a economia de mercado, e o bloco soviético, onde a economia era planificada. O bloco soviético desaparece em meados de $1991^{4}$.

2 Disponível em: <http://educaterra.terra.com.br/voltaire/mundo/segunda_guerra.htm>. Acesso em: 26 jan. 2008. E também: KENNEDY, Paul. Ascensão e Queda das Grandes Potências. 3. ed. Rio de Janeiro: Campus, 1988.

3 MAGALHÃES, José Carlos de. Direito Internacional Econômico. Curitiba: Juruá, 2005. p. 185186.

4 Mikhail Gorbatchov ao assumir o poder na URSS, em 1985, substituindo Konstantin Tchernenko deu início a reformas que redundaram no fim da URSS ao aplicar dois conceitos em uma sociedade fechada: a glasnost (transparência), diminuindo a censura e a perestroika (reestruturação) que eram reformas da economia. Os setores mais conservadores tentam um golpe, que fracassa em virtude da oposição de Boris leltsin, Presidente do Soviete Supremo da Federação Russa. Gorbatchov renuncia e a URSS deixa de existir. Mas, no plano exterior, desde 1988 havia um grande diálogo com os EUA, encerrando a chamada "guerra fria". 
A consolidação do sistema capitalista exteriorizada com a queda do bloco soviético e a subseqüente criação da OMC trouxeram, por óbvio, conseqüências para o mundo inteiro. Novos mercados foram abertos e mantidos pelas economias 5 dos países detentores da tecnologia e do capital, no mais puro espírito weberiano ${ }^{6}$. Globalização ${ }^{7}$, mercado financeiro, commodities, hedge etc., passam a ser palavras, hoje, incorporadas ao vocabulário coloquial da maior parte dos países do mundo. Para os Estados da América Latina, estes "novos fatores" acabam por gerar novas dificuldades $^{8}$, por tratar-se de região, historicamente, menos avançada ${ }^{9 / 10}$.

5 Adam Watson reforça isso ao salientar que "as inovações mais impressionantes na organização da sociedade internacional desde a Segunda Guerra Mundial ocorreram no campo econômico. A integração econômica crescente do sistema torna necessárias novas práticas e instituições. A ordem econômica é agora mais integrada e mais administrada por uma diretoria institucionalizada de grandes potências econômicas do que qualquer coisa tentada anteriormente por uma sociedade de Estados politicamente independentes. A novidade e a dimensão dessa empreitada ainda não foram completamente percebidas". (WATSON, Adam. A evolução da sociedade internacional. Brasília: UnB, 2004. p. 435-436)

6 WEBER, Max. A Ética Protestante e o "Espírito" do Capitalismo. São Paulo: Cia. das Letras, 2004. p. 42-43. "Lembra-te que tempo é dinheiro... Lembra-te que crédito é dinheiro... Lembra-te que o dinheiro é procriador por natureza e fértil. O dinheiro pode gerar dinheiro... Lembra-te que um bom pagador é senhor da bolsa alheia."

7 René Dreifuss sustenta que "....a globalização é um termo que se refere a fenômenos do âmbito da produção e da comercialização de produtos. É um processo que compreende mudanças significativas no sistema produtivo a partir da utilização crescente de métodos, meios, recursos de produção que ultrapassam fronteiras nacionais. E, mais adiante complementa que $\mathrm{A}$ globalização deriva, por um lado, de um redesenho do sistema financeiro. Ele tem um processo de diferenciação interna que enfatiza um tripé bancário, dos fundos de pensão e fundos mútuos e das seguradoras. Dentro desse sistema financeiro, um processo intenso de absorção, de incorporação, de concentração de capitais, e de diferenciação interna no próprio sistema financeiro, com o nascimento, a consolidação ou a expansão dos fundos, do mundo dos seguros, dos investimentos produtivos, modificam radicalmente as possibilidades de vinculação do sistema financeiro ao industrial, e a alavanca fundamental da globalização é o complexo que inclui a informática, as telecomunicações, a microeletrônica e a robótica, e que, junto às modificações do sistema financeiro, induz transformações no sistema de produção e obriga as grandes corporações a pensar numa matriz de conhecimento, e não mais de produto. A competência crucial passa a ser a de desenvolver uma matriz científica e um coração tecnológico, que permitem modificar radicalmente o panorama da produção, das possibilidades de consumo, do mundo do trabalho, da gestão e da própria pesquisa, possibilitando a introdução de novos produtos. Além dessas duas questões, pode-se mencionar os capitais existentes, a reformulação das corporações, o redesenho que, lentamente, vai sendo imposto no campo da política, entre outros". (DREIFUSS, René. Os códigos do admirável mundo novo. Lições de Mestres. Rio de Janeiro: Campus, 1998. p. 231)

8 Sobre o assunto ver: WINTER, Luís Alexandre Carta; RAMOS, Heidy Rodriguez (Orgs.). IberoAmérica: os desafios da integração da América Latina e sua inserção no sistema internacional. Curitiba: Juruá, 2006.

9 Como analisado nos Capítulos III e IV. Celso Furtado faz uma contundente análise das fases do desenvolvimento industrial e econômico e chama a atenção que "a íntima interdependência 
Neste século XXI, parece ser claro que o modelo de Hobbes em seu Leviatã

(e também em Os Elementos da Lei Natural e Política), e absorvido pela Paz de

Vestfália em 1648, criando as bases para a estrutura do Estado ${ }^{11}$-nação ${ }^{12}$ clássico $^{13}$,

existente entre a evolução da tecnologia nos países industrializados e as condições históricas do seu desenvolvimento econômico. Essa tecnologia, na forma em que se apresenta hoje, incorporada aos equipamentos industriais, resulta, portanto, de um lento processo de decantação" e lembra que, decorrente das linhas de desenvolvimento da economia industrial, "o efeito do impacto da expansão capitalista sobre as estruturas arcaicas variou de região para região, ao sabor de circunstâncias locais, do tipo de penetração capitalista e da intensidade desta. Contudo, a resultante foi quase sempre à criação de estruturas híbridas, uma parte das quais tendia a comportar-se como um sistema capitalista, a outra, a manter-se dentro da estrutura preexistente. Esse tipo de economia dualista constitui, especificamente, o fenômeno do subdesenvolvimento contemporâneo. O subdesenvolvimento é, portanto, um processo histórico autônomo, e não uma etapa pela qual tenham, necessariamente, passado as economias que já alcançaram grau superior de desenvolvimento e arremata que a etapa superior do subdesenvolvimento é alcançada quando se diversifica o núcleo industrial e este fica capacitado a produzir parte dos equipamentos requeridos pela expansão de sua capacidade produtiva. $O$ fato de se alcançar essa etapa não implica que o elemento dinâmico principal passe, automaticamente, a ser o núcleo industrial ligado ao mercado interno. O processo normal de desenvolvimento do núcleo industrial é ainda o da substituição de importações; destarte, o elemento dinâmico reside ainda na procura preexistente formada, principalmente, por indução externa - e não nas inovações introduzidas nos processos produtivos, como ocorre nas economias industriais totalmente desenvolvidas. No entanto, como o sistema é capaz de produzir parte dos bens de capital de que necessita para expandir sua capacidade produtiva, o processo de crescimento pode continuar por muito mais tempo, mesmo que haja estancamento da capacidade de importação. O desenvolvimento se opera, em tais condições, entretanto, com forte pressão inflacionária". (FURTADO, Celso. Desenvolvimento e subdesenvolvimento. In: BIELSCHOWSKY, Ricardo (Org.). Cinqüenta anos de pensamento na CEPAL. Rio de Janeiro: Record, 2000. p. 251-260)

10 Sobre o tema ver: WINTER, Luís Alexandre Carta; WACHOWICZ, Marcos. A construção de uma identidade. Anais do COMPEDI, Belo Horizonte, 14-16.11.2007.

11 Celso de Albuquerque Mello discorre que a palavra "'Estado' se origina do latim status ('estar de pé', 'a idéia de uma certa estabilidade de situação'). Na Antiguidade e Idade Média a palavra status era a 'boa ordem' (status reipublicae). No século XIII significa 'estrutura jurídica'. Na Idade Média, o Estado urbano é denominado Civitas e a monarquia territorial é chamada de regnum. $A$ palavra respublica era usada para a reunião de fiéis e foi Maquiavel, em sua obra 0 Príncipe, 1513, quem utilizou a palavra, pela primeira vez, no seu sentido moderno, 'de uma entidade política geral situada acima dos regimes particulares'". (MELLO, Celso de Albuquerque. Curso de Direito Internacional Público. 13. ed. Rio de Janeiro: Renovar, 2001. v. I, p. 373)

12 Raymond Aron sustenta que "uma nação é sempre o resultado da história, uma obra dos séculos; nasce por meio de provas, a partir de sentimentos experimentados pelos homens, mas com a influência da força, a força de uma unidade política que destrói as unidades preexistentes, ou a força do Estado que ordena as regiões e as províncias. [...] a nação passava, no fim do século XIX, pela obra-prima da história, a realização com êxito de um esforço secular. Os homens criavam juntos uma cultura e, por um plebiscito cada dia renovado, decidiam viver em conjunto. [...] A vontade afirmada pelas nações tornou-se uma expressão de orgulho coletivo, uma pretensão de superioridade. Como as nações soberanas estão engajadas numa competição de potência, as conquistas tiveram sua intensidade aumentada, em vez de ser atenuada. As guerras entre os monarcas transformaram-se em guerras entre os povos. Os homens passaram a acreditar que o destino das culturas era jogado nos campos de batalha, juntamente com a sorte das províncias". (ARON, Raymond. Paz e Guerra Entre as Nações. Clássicos IPRI. Brasília: UnB, 2002. p. 385-386). Adalto Novaes corrobora essa idéia e vai além ao afirmar que, "historicamente explicáveis, Estado e Nação parecem ter um destino comum: criar a ideologia dos tempos modernos, que é o conceito de soberania (nacional ou popular). É esse conceito que dá conteúdo concreto à idéia de Estado, que supõe a existência de uma vontade comum dos indivíduos e, 
é insuficiente frente aos novos atores, sejam transnacionais ${ }^{14}$, sejam até mesmo

ONGs, que têm objetivos-fins menos comerciais. Com o advento da sociedade de

informação ${ }^{15}$, rediscutir o Estado e a própria relação de poder parece ser o papel dos

juristas, filósofos ${ }^{16}$ e sociólogos deste século ${ }^{17}$.

portanto, unidade ideal; e isso que atribui coerência e legitimidade ao poder do Estado: a soberania 'racional e necessária' que emana da vontade o povo - 'realização histórica do Espírito' - e da nação. O Estado é, na expressão de Hegel, a organização concreta do Espírito de um povo, do qual é a revelação. O Estado é, portanto, a forma visível da soberania, e que, por isso mesmo, atribui-se o poder de resolver à base da violência, quando a ideologia falha, qualquer conflito surgido na sociedade, uma vez que povo e Estado representam a mesma realidade, isto é, 'vontade comum' e 'unidade racional'. Negação da multiplicidade do múltiplo, o Estado é expressão lógica do Um, que se separa do corpo da sociedade, tornando-se instância exterior e superior". (NOVAES, Adalto. A invenção e a crise do Estado-Nação. In:

do Estado-Nação. Rio de Janeiro: Civilização Brasileira, 2003. p. 17-18)

(Org.). A crise

13 Sobre a formação do Estado Moderno, ver BLIN, Arnaud. La Paix de Westphalie ou la naissance de l'Europe politique moderne. Paris: Complexe, 2006.

14 Multinacionais ou transnacionais? Celso Albuquerque Mello descreve que "A ONU consagrou a expressão transnacional, isto é, de empresas que atuam além e através das fronteiras estatais. É mais correto, porque o qualificativo 'multinacional' podia conduzir a equívoco se fosse interpretado ao pé da letra, vez que estas empresas não tem muitas nacionalidades. Assim a matriz é norteamericana, a subsidiária no Brasil é brasileira, a subsidiária na Argentina é argentina etc.". (MELLO, Celso Albuquerque. Direito Internacional Econômico. Rio de Janeiro: Renovar, 1993. p. 105)

15 Marcos Wachowicz ressalta os "paradoxos existentes na sociedade informacional e os limites do Direito em regulá-los" (p. 259). E à p. 248, lembra que "todos os dados armazenados em computadores, a qualquer momento, mediante a violação de códigos de softwares criptográficos, podem ser acionados e totalmente devassados". (WACHOWICZ, Marcos. Propriedade Intelectual do Software \& Revolução da Tecnologia da Informação. Curitiba: Juruá, 2004). É interessante lembrar que, historicamente, por legado das Escolas Estatutárias, foi fixada a competência territorial, em matéria de direito penal. Com os crimes do ciberespaço torna-se necessário uma maior cooperação entre os Estados.

16 Charles Morazé, em uma preciosa análise argumenta que "desde as grandes descobertas, a história do planeta é a de sua unidade. Os primórdios são agitados; conquistadores, ladrões, senhores do tráfico de negros, negociantes sem escrúpulos não foram impedidos antes de muito tempo pelos missionários filantropos de trazer para si uma enorme quantidade de riquezas indevidas. Quando a concorrência que faziam entre si e um certo despertar da opinião e dos interesses melhor compreendidos forçaram a maior honestidade, continuou-se a ter como uma justa compensação às vantagens tiradas das colônias, os valores imaginários e os usos que efetivamente bem serviram à Europa, mas que eram apenas ilusórios ou inadequados nos países tão diferentes para onde eram exportados. E, entretanto, por efeito dessa perigosa injustiça cuja história inconsciente faz uma necessidade, a acumulação de bens assim realizada em proveito de uma pequena região privilegiada do mundo, tornada centro de tudo antes de padecer por sua vez de seus próprios excessos, põe em andamento um processo natural de desenvolvimento chamado a ter conseqüências universais". (MORAZÉ, Charles. A lógica da história. São Paulo: Difusão Européia do Livro, 1970, p. 203)

17 Discutir as instituições é um dos grandes legados do ocidente. No discurso de Péricles, no séc. IV a.C., isto já se verificava. "[...] A nossa constituição política não segue as leis de outras cidades, antes lhes serve de exemplo. O nosso governo chama-se democracia, porque a administração serve aos interesses da maioria e não de uma minoria. De acordo com as nossas leis, somos todos iguais no que se refere aos negócios privados. Quanto à participação na sua vida pública, porém, cada qual obtém a consideração de acordo com os seus méritos e mais importante é o valor pessoal que a classe a que pertence; isto quer dizer que ninguém sente o obstáculo de sua pobreza ou da condição social inferior, quando o seu valor o capacite a prestar serviços à cidade. 
Antes mesmo da moderna rede de informação, alguns fatos prepararam o terreno para certa padronização dos costumes e mesmo das normas. Questões como a criação do programa "ISO-9000", em que são criadas condições de uma otimização do produto, não importando onde ele seja fabricado, aliado ao fato, aqui relevante, de serem as empresas norte-americanas, em razão da peculiar competição que acirra seu mercado, vez que a poupança norte-americana está calcada em ações que devem dar lucros, fez com que as mesmas, de um lado, mantendo a qualidade, buscassem diminuir os custos.

Ora, alguns dos componentes dos custos são impostos, e outros, os encargos sociais. Como a renda per capita norte-americana é alta, pode-se imaginar deslocar-se a produção para um outro país, onde a renda seja substancialmente menor, com vantagens que esse país possa dar, em termos de suspensão ou mesmo de isenção de impostos; desse modo, mantendo a qualidade do produto, consegue-se melhorar o preço e, com isso, vender-se mais, obtendo-se maiores dividendos. Tal questão força o competidor a agir dessa mesma forma. O resultado disso é que, de um lado, as empresas, agora transnacionais, vão ocupando espaços a exemplo de Gargântua e Pantagruel, da obra de Rabelais, forçando os Estados a tomarem medidas para padronizar uma legislação frente a um avanço desenfreado dessas empresas e, de outro, ao mesmo tempo, procurar com que elas continuem atuando junto a estes Estados, em face de existir o efetivo interesse de estas empresas continuarem lá, gerando empregos e negócios ${ }^{18}$. Este fator faz com que o

No que corresponde à República, pois, governamos livremente e, ainda, nas relações que mantemos diariamente com os nossos aliados e vizinhos, não nos irritamos porque ajam à sua maneira, nem consideremos como uma humilhação os seus prazeres e alegrias que, apesar de não nos produzir danos materiais, nos causam pesar e tristeza, ainda que sempre tratemos de dissimulá-los...". (MOREIRA, Adriano et al. Legado Político do Ocidente (O Homem e o Estado). Lisboa: Almedina, 1988)

18 José Carlos de Magalhães ressalta que a empresa transnacional, sob o enfoque de organização juridicamente estabelecida, "verifica-se que é dotada de poder similar ao de qualquer governo. Os 
próprio sistema capitalista se amolde, plasticamente, às novas realidades ${ }^{19}$ que ele

mesmo ajuda a alimentar ${ }^{20}$.

A essa padronização, o Prof. José Carlos de Magalhães chama de

mundialização do direito ${ }^{21}$.

seus dirigentes, possuindo prerrogativas estatutárias, agem como que autoridades governamentais, estabelecendo normas que se projetam para fora do âmbito interno da empresa. O poder de negar emprego, de selecionar empregados, de influir nos salários dos concorrentes, pela adoção de política salarial própria, o poder de decidir sobre a localização de uma nova subsidiária, de distribuir lucros ou decidir sobre a sua reinversão, o de decidir que mercado deve ser suprido e qual a mercadoria a ser produzida, a que direção deve encaminhar pesquisas e em que extensão utilizá-las, tudo isso fica dentro do campo exclusivamente privado da empresa, sem que as autoridades governamentais possam com ele eficazmente interferir. [...] O poder de influir no mercado e afetar toda uma comunidade acaba por criar na empresa uma estrutura quase que governamental similar à do Estado. Realmente, a grande empresa transforma-se em centro de decisões que afetam consumidores, fornecedores, revendedores e toda uma comunidade de pessoas e entidades que giram em torno dela. Na área internacional o poder da empresa fica evidenciado nos setores que afetam a segurança do Estado ou o seu desenvolvimento econômico. Petróleo, computadores e energia são exemplos. As multinacionais que exploram esses setores desempenham funções verdadeiramente públicas e suas negociações com governos são feitas em pé de igualdade, freqüentemente por meio de acordos. É verdade que ao Estado cabe o poder de terminar contratos e de expropriar, mas é verdade também que a empresa possuía a arma do controle econômico do mercado internacional, do qual aquele depende". (MAGALHÃES, José Carlos de. Direito Internacional Econômico. Curitiba: Juruá, 2005. p. 210-211)

19 Um exemplo disso é que, com a queda do sistema soviético, o próprio sistema capitalista adaptase e começa a discutir "cláusulas sociais", antes uma questão pouco considerada. CACCIAMALI, Maria Cristina em artigo intitulado "Liberalización Económica y Derechos Fundamentales en el Trabajo en América Latina", p. 91, na obra que organizou intitulada Los Desafíos de la Política Social en América Latina, Caracas: Garcia \& Hijo, 2002, sustenta que "La inclusión de derechos laborales en las relaciones comerciales internacionales se ha transformado en una propuesta política que diferencia los intereses de los gobiernos de las naciones industrializadas, con el apoyo del sector empresarial y de los sindicatos, lideran demandas para elevar las normas mínimas laborales, enfrentándose a la resistencia de los gobiernos y empresarios de los países en vías de desarrollo".

20 Lauro Campos sustenta "que o fantástico desenvolvimento capitalista produziu as crises recorrentes que, desde a crise de 1810 vem tornando-se cada vez mais completas e complexas. $\mathrm{O}$ capitalismo desenvolveu espantosamente não só as forças produtivas, mas as forças improdutivas e destrutivas, desviando para setores bélicos parte substancial de seus recursos". (CAMPOS, Lauro. A crise completa - A Economia Política do Não. São Paulo: Bomtempo, 2001, p. 281)

${ }^{21}$ Magalhães define a mundialização como "fenômeno constatado pelas leis-modelo aprovadas por convenções internacionais e pelos contratos-tipo adotados em negócios privados internacionais, a indicar uniformidade" (MAGALHÃES, José Carlos de. Aula Magna proferida no Curso de Direito da Facinter, Curitiba, em 22 de agosto de 2007). Luiz Otávio Pimentel, citando Giddens e Vidal Villa, diz que "a mundialização se refere principalmente a esse processo de alargamento no concernente aos métodos de conexão entre diferentes contextos sociais ou regiões que se convertem em uma rede ao longo de toda a superfície da terra [...] pode definir-se como a intensificação das relações sociais em todo o mundo pelas quais se enlaçam lugares distantes, de tal maneira que os acontecimentos locais estão determinados por acontecimentos que ocorrem a muitos quilômetros de distância e vice versa e que o termo globalização é mais comum nos países anglo-saxônicos e que os países europeus continentais utilizam o vocábulo mundialização, com mais amplo sentido que a globalização". (GIDDENS e VIDAL VILLA apud PIMENTEL, Luiz Otávio. MERCOSUL no Cenário Internacional, Direito e Sociedade. Curitiba: Juruá, 1998. v. II, p. 366367). René Dreifuss sustenta que "a mundialização lida com mentalidades, hábito, estilos de 
Por outro lado, em razão do dinamismo da sociedade moderna, ficam sem

sentido falar de perda da soberania ${ }^{22}$ do Estado frente aos novos atores desta

sociedade, e, no entender de Magalhães, em vez de falar sobre perda de

soberania ${ }^{23}$, há que se falar da jurisdição do Estado ${ }^{24}$.

comportamento, com usos e costumes e a criação de denominadores comuns. É um fenômeno cujas bases já estão sendo consolidadas, na medida em que estamos lidando com uma população que passou a se conhecer. As atividades ligadas ao turismo respondem, hoje, por uma parcela poderosa do produto interno bruto planetário. Passamos a viajar, a nos visitar como turistas ou a serviço de empresas (...). Vivemos uma homogeneização de produtos, acelerada a partir da década de 70 , por intermédio da exportação de certos produtos nacionalmente desenvolvidos mas que são aceitos por vontade ou condicionamento em diversos outros espaços do planeta: serviços, sabores, vestuário" (DREIFUSS, René. Ob. cit., p. 238-239). Eric Hobsbawn constata "que talvez a característica mais impressionante do fim do século XX seja a tensão entre esse processo de globalização cada vez mais acelerado e a incapacidade conjunta das instituições públicas e do comportamento coletivo dos seres humanos de se acomodarem a ele. É curioso observar que o comportamento humano privado teve menos dificuldade para adaptar-se ao mundo da televisão por satélite, ao correio eletrônico, às férias nas Seychelles e ao emprego transoceânico". (HOBSBAWN, Eric. Era dos Extremos. O breve século XX, 1914-1991. São Paulo: Companhia das Letras, 1997. p. 24)

22 Construíram-se conceitos, mesclando a idéia de Estado, Nação e Soberania como condições indissociáveis para o Estado-Nação. A bem da verdade que, a idéia de soberania surgiu de um Decreto Papal - a Pastoralis Cura (1313) mas, faticamente, a primeira exposição sistemática de soberania é atribuída a Jean Bodin, no século XVI, na obra "Os Seis Livros da República". A expressão original da soberania era rex superiorem non recognoscens in regno suo est imperator (o rei, que não reconhece nenhum outro poder acima de si, tem, no âmbito do próprio reino, os mesmos poderes que tem o imperador sobre todo o Império), que passou, mais tarde a Suprema potestas superiorem non recognoscens (poder supremo que não reconhece outro acima de si). Sobre esse assunto ver: WINTER, Luís Alexandre Carta. A construção histórica do conceito de Soberania, publicado nos Anais do V Congresso de Direito Internacional, v. X, p. 531-544. Michel Foucault argumenta que "a soberania é a teoria que vai do sujeito para o sujeito, que estabelece a relação política do sujeito com o sujeito ela se confere, no início, de uma multiplicidade de poderes que não são poderes no sentido político do termo, mas são capacidades, possibilidades, potências, e que ela só pode constituí-los como poderes, no sentido político do termo, como a condição de ter, entrementes, estabelecido, entre as possibilidades e os poderes, um momento de unidade fundamental e fundadora, que é a unidade do poder. Que essa unidade do poder assuma a fisionomia do monarca ou a forma do Estado pouco importa; é dessa unidade do poder que vão derivar as diferentes formas, os aspectos, mecanismos e instituições de poder. A multiplicidade dos poderes, entendidos como poderes políticos, só pode ser estabelecida e só pode funcionar a partir dessa unidade do poder. Finalmente, a teoria da soberania mostra como um poder pode constituir-se não exatamente segundo a lei, mas segundo uma certa legitimidade fundamental, mais fundamental do que todas as leis, que é um tipo de lei geral de todas as leis e pode permitir às diferentes leis funcionarem como leis". (FOUCAULT, Michel. Em Defesa da Sociedade. São Paulo: Martins Fontes, 2002. p. 49-50). O mesmo raciocínio pode ser perpetrado para a criação dos blocos econômicos.

${ }^{23}$ Pensando-se em um quadro sinótico, dentro de um contexto organicista, o direito dos Estados compreenderia, como direito fundamental, o direito à existência, este, desdobrado em direito à liberdade e direito de defesa e conservação. $O$ direito a liberdade, à semelhança do ser humano, atua em duas áreas: internamente, que no homem seria chamado de "liberdade de pensamento" e, na inter-relação com o outro, em sua exteriorização, como a verbalização do pensamento e a liberdade de locomoção. Para o Estado, essa "liberdade" ganha a alcunha de "soberania", e, embora una, atua em duas áreas: no âmbito interno, onde é chamada de autonomia, que compreende o direito de organização política, o direito de legislação, o direito de jurisdição e o 
A real necessidade do Estado ${ }^{25}$ pauta-se em sua importante função social ${ }^{26}$.

\author{
Associar-se e enfrentar os desafios do capitalismo moderno parece ser o caminho ${ }^{27}$.
}

direito de domínio; e no âmbito externo, onde é chamado de independência, compreendendo o direito de legação ou representação política, o direito de celebrar acordos e/ou convenções, o direito de fazer a guerra e celebrar a paz, o direito à igualdade e o direito de respeito mútuo. 0 direito de defesa e conservação compreenderia o direito de impedir o ingresso de indesejáveis, o direito de retirar, compulsoriamente, estrangeiros nocivos à ordem e/ou a segurança pública e o direito de celebrar alianças defensivas.

24 Magalhães discorre que "se, de um lado, o conceito de soberania prevalece em sua plenitude e carregado do componente político-jurídico que lhe é ínsito, a necessidade de adaptação à realidade econômica de divisão do mundo e da interdependência fez evoluir a noção de soberania para a de competência territorial [...]". (MAGALHÃES, José Carlos de. Direito Internacional Econômico. Curitiba: Juruá, 2005. p. 262)

25 Marcos T. Kaplan argumenta que o "Estado não é expressão de uma racionalidade transcendente ou imanente à sociedade, mas seu produto, seu modo de expressão e organização, sua síntese oficial e simbólica. Historicamente, parece ir emergindo e se impondo a partir do momento em que uma sociedade alcança certo grau significativo de desenvolvimento. Supõem a preexistência de condições em que a divisão de trabalho e funções, a gama de conflitos entre classes e grupos, a luta pelo controle e exercício exclusivo do poder levam à cisão da sociedade em unidades separadas, em interesses particulares e interesse geral, o público e o privado, a comunidade e o indivíduo, com a emergência e agravamento de antagonismos irreconciliáveis e violentos e de ameaças externas que atentam contra a coesão e a própria existência da sociedade. A partir destas condições e baseado nelas, o Estado parece surgir e se desenvolver quando a sociedade de alguma forma perde sua iniciativa e poderes, abandona a gestão de seus interesses comuns, transmite-os - por debilidade espontânea ou imposição coativa - à instituição governamental. O Estado assume - em parte como pretensão e em parte como realidade - a consciência, a racionalidade, o poder organizador e coesivo, a representatividade do interesse geral, perdidos ou de que carecem a sociedade e os grupos particulares que a integram, pretende organizar, sistematizar, totalizar a sociedade. Expressa, institui e conserva os conflitos que lhe dão ordem e sentido, atenuando-os e mantendo-os em compatibilidade com a ordem social básica. Apropria-se do poder da sociedade e monopoliza a força coletiva. Transforma os interesses comuns da sociedade nos chamados interesses gerais, que define, qualifica e administra a seu modo, subordinando os interesses particulares dos grupos e indivíduos aos das entidades governamentais (burocracia, classes e frações dominantes) e dos grupos humanos que as personificam e controlam". (KAPLAN, Marcos T. Formação do Estado Nacional. Rio de Janeiro: Eldorado, 1974. p. 19)

26 Martin van Creveld sustenta que o "Estado, desde meados do século XVII é a mais importante das instituições modernas, está em declínio. Da Europa ocidental à África, voluntária ou involuntariamente, muitos Estados estão se fundindo em comunidades maiores ou se desmoronando. Quer se desmoronem, quer se fundam, muitas de suas funções estão passando às mãos de uma série de instituições que, seja qual for sua natureza exata, não são Estados. Globalmente falando, o sistema internacional está se afastando da configuração de Estados distintos, territoriais, soberanos, legalmente iguais, rumo a estruturas diferentes, mais hierárquicas e, em muitos aspectos, mais complicadas". (CREVELD, Martin van. Ascensão e declínio do Estado. São Paulo: Martins Fontes, 2004. Prefácio ). Por outro lado, o Estado continua a exercer influência decisiva no mundo contemporâneo, e, na ótica de Martin Carnoy, "o problema básico das sociedades capitalistas avançadas, após dois séculos de crescimento econômico, não é mais a adequação dos recursos ou sua alocação eficiente para produção máxima. O modo como isso se dá a definição do que seja produção, o que se produz e quem decide a política de desenvolvimento são, hoje, problemas econômicos significativos. E esses problemas estão situados tanto na arena política como na produção. Há outro motivo para a importância da política: na medida em que as economias se desenvolveram em todo o mundo, o setor público, aqui chamado de Estado, cresceu em importância em todas as sociedades, da industrial avançada à exportadora de bens primários do Terceiro Mundo, e em todos os aspectos da sociedade, não apenas político, como econômico (produção, finanças, distribuição), ideológico (educação escolar, os meios de comunicação) e quanto a força legal (polícia, forças armadas). Por que isso ocorre e 
É neste contexto que surgem os Blocos Econômicos e, dentre eles, o

MERCOSUL.

como se configura o crescente papel do Estado têm se tornado uma preocupação crucial para os cientistas sociais de nossos dias". E conclui o autor: "O Estado parece deter a chave para o desenvolvimento econômico, para a segurança social, para a liberdade individual e, através da sofisticação crescente das armas, para a própria vida e a morte. Compreender o que seja política no sistema econômico mundial hoje é, pois, compreender o Estado nacional e compreender o Estado nacional no contexto desse sistema é compreender a dinâmica fundamental de uma sociedade". (CARNOY, Martin. Estado e a Teoria Política. 7. ed. Campinas: Papirus, 2001. p. 9)

27 Peter Drucker discorre que, "desde o fim da Segunda Guerra Mundial, o Estado-Nação soberano vem perdendo sua posição como órgão único de poder. Internamente os países desenvolvidos estão rapidamente se transformando em sociedades pluralistas de organizações. Externamente, algumas funções governamentais estão se tornando transnacionais, outras regionais, como por exemplo a Comunidade Européia; e outras estão sendo tribalizadas. O Estado-Nação não irá desaparecer. Ele poderá permanecer como órgão político mais poderoso ainda por muito tempo, mas não será indispensável. Ele irá dividir cada vez mais seu poder com outros órgãos, outras instituições, outras entidades criadoras de políticas". (DRUCKER, Peter. Sociedade póscapitalista. São Paulo: Pioneira, 1999. p. XIX). François Châtelet e Évelyne Pisier-Kouchner argúem que "o Estado-Nação nascido na idade clássica continua a ser a realidade política essencial e se considerarmos os Estados-nações como soberanias voltadas para o exterior e comprometidas com a realidade internacional, constataremos que os mais fortes e os mais avançados dentre tais Estados desenvolveram suas políticas coloniais até transformá-las em expansionismo imperial e que ainda hoje, após a época da descolonização, a partilha do mundo em dois ou três blocos mal oculta a efetividade de impérios de novo tipo. $O$ imperialismo não é apenas o estágio supremo do capitalismo, ele é inerente a toda formação estatal e a suas modalidades técnicas de dominação e, ao mesmo tempo, os princípios e idéias de que ele se vale são função das diferentes estruturas econômico-políticas que o produzem, de suas coerências e de suas contradições". (CHÂTELET, François; PISIER-KOUCHNER, Évelyne. As Concepções Políticas do Século XX, História do Pensamento Político. Rio de Janeiro: Zahar, 1983. p. 293294) 


\section{CAPÍTULO I}

\section{OS BLOCOS ECONÔMICOS ${ }^{28}$}

Fenômeno conhecido, de certa forma, ao longo da história ${ }^{29}$, a possibilidade moderna do surgimento dos Blocos Econômicos ganha uma melhor dimensão com o GATT-47 (Acordo Geral sobre Tarifas Aduaneiras e Comércio) ${ }^{30 / 31}$.

O modelo comunitário está calcado em bases verticais, ou seja, os Estados têm limitada sua soberania. Esse compartilhamento é que assegura o chamado poder de integração, poder comunitário ou supranacional, dando margem ao surgimento do direito comunitário, a partir desse modelo, um direito que tem prevalência sobre o nacional e, por essa razão, unifica não só os Estados-membros, mas também as pessoas físicas ou jurídicas no âmbito interno de cada um deles, diretamente.

Para atingir este modelo comunitário, atualmente só alcançado pela União Européia, os Estados-Partes devem assegurar-se de princípios para que essa

${ }^{28}$ Sobre o tema ver: WINTER, Luís Alexandre Carta. A crise do modelo presidencialista no âmbito do MERCOSUL. Curitiba: Juruá, 2002. p. 103-109.

29 Como, por exemplo, a União Aduaneira dos Estados Alemães (Zollverein) fundada em 1834 sob os auspícios da Prússia. Agrupava quase todos os Estados alemães a exceção do Império Austríaco, Hannover, Braunschweig, Oldenburg e Schaumburg-Lippe. Estes quatro últimos, tendo criado também em 1834, uma união aduaneira (Steuerverein), a dissolveram em 1854 e seus participantes entraram para o Zollverein (União Aduaneira) o que, estabelecendo uma fronteira alfandegária comum, facilitou a futura unificação política da Alemanha. Sobre o tema ver: ANDERSON, Perry. Linhagens do Estado Absolutista. São Paulo: Brasiliense, 1985.

30 Em inglês: General Agreement on Tariffs and Trade. O art. XXIV do GATT-47 deu a possibilidade de criação tanto das Áreas de Livre Comércio, quanto da União Aduaneira.

31 Mas sua sistematização doutrinária deve-se a partir da obra de Bela Balassa (BALASSA, Bela. Teoria da Integração Econômica. Lisboa, 1972), e em À Procura de uma Integração Econômica, publicada in: WIONCZEK, S. Miguel (Org.). A Integração Econômica da América Latina. Rio de Janeiro: Cruzeiro, 1966. p. 40. Aqui Balassa concebeu a integração "como um processo e um estado de coisas. Vista como um processo, a integração encerra várias medidas destinadas a abolir discriminações existentes entre unidades econômicas pertencentes a diversos estados nacionais. Contemplada como um estado de coisas, pode ser representada pela ausência de várias formas de discriminação entre economias nacionais". 
construção esteja solidificada em bases firmes e aceitar o compartilhamento de sua soberania. Do modelo de cooperação, ao modelo comunitário, temos várias fases de integração, nas quais os Estados que pretendem formar um grupo regional escolhem a fase pretendida, partindo de seus interesses. Destaque-se que cada nível de integração corresponde a uma limitação crescente de competências inerentes à soberania nacional. A seguir são descritos, sinteticamente, cada nível.

\section{a) Zona de Preferências Alfandegárias}

Os países que integram a zona de preferências negociam entre si vantagens alfandegárias, ou seja, a redução de alíquotas de importação, não cogitando, porém, uma relação macroeconômica e sem o objetivo de formar um verdadeiro bloco econômico. Um exemplo típico é o PAR (Preferência Alfandegária Regional) que ocorre na esfera da ALADI.

\section{b) Zona de Livre Comércio}

A zona de livre comércio está conceituada no artigo XXIV, 8, "b", do GATT que a autoriza, dizendo: se entenderá por zona de livre comércio, um grupo de dois ou mais territórios aduaneiros entre os quais se eliminam os direitos de aduana e as demais regulamentações comerciais restritivas com respeito ao essencial dos intercâmbios comerciais dos produtos originários dos territórios constitutivos da dita zona de livre comércio ${ }^{32}$.

\footnotetext{
32 Luiz Olavo Batista define-a como "consiste na livre circulação das mercadorias no seu interior, sem restrições quantitativas e sem imposição alfandegária. Entretanto, cada um dos participantes da ZLC pode negociar com terceiros países da forma que melhor servir aos seus interesses comerciais". (BATISTA, Luiz Olavo. O MERCOSUL, suas instituições e ordenamento jurídico. São Paulo: LTr., 1998, p. 47)
} 
Esta liberdade no negociar com terceiros países impõe a criação de regras de origem que permitem distinguir entre os produtos de dentro e de fora da zona, através de certificados, sujeitos a impostos e eventualmente a restrições. Exceto se, por outros tratados, tais restrições tenham sido proibidas.

No processo de criação de uma zona de livre comércio, há que se superarem certos obstáculos. O primeiro é o do estabelecimento de regras de origem, que servem para a determinação da real proveniência dos produtos.

A qualificação acima citada deve obedecer a certos critérios que são estipulados nas regras de origem, os quais fixam os percentuais de matéria-prima, mão-de-obra, fase de elaboração, dentre outros e permitem dizer se a fabricação foi local ou se o produto é originário da Zona de Livre Comércio.

Objetivam evitar que produtos vindos de fora da zona recebam tratamento privilegiado; após, há a seleção dos produtos que vão integrar a Zona de Livre Comércio ${ }^{33}$.

Dentre os modelos de Zona de Livre Comércio temos o NAFTA, o ASEAN, a ALCA, dentre outros.

\section{c) União Aduaneira}

O artigo XXIV, 8, “a”, i e ii, do GATT, autoriza a união aduaneira. Esta pode ser definida da seguinte maneira: se entenderá por território aduaneiro todo território

${ }^{33}$ Como bem lembrado por Wagner Rocha D'angelis, "no foro do GATT (hoje OMC), um acordo comercial só pode ser considerado uma Zona de Livre Comércio se envolver pelo menos $80 \%$ dos bens comercializados entre os países-membros. O universo desses bens comercializáveis é classificado através de um sistema denominado de Nomenclatura, utilizado por todos os países. Todo produto se encaixa em algum item da Nomenclatura". (D'ANGELIS, Wagner Rocha. MERCOSUL - Da Intergovernabilidade à Supranacionalidade? Curitiba: Juruá, 2001. p. 71) 
que aplique uma tarifa distinta ou outras regulamentações comerciais distintas a uma parte substancial de seu comércio com os demais territórios.

A união aduaneira, além de características da Zona de Livre Comércio, como a livre circulação de mercadorias, comporta uma tarifa aduaneira comum, eliminando os complexos problemas da definição das regras de origem. Tem seu início com a implantação da Tarifa Externa Comum (TEC) que, uma vez paga, permite a circulação dos produtos nos países do Bloco, sem novo pagamento do imposto de importação. A alíquota será comum para todos os Estados partícipes do bloco.

São os requisitos de uma zona aduaneira: eliminação das restrições comerciais tarifárias e extra-tarifárias, adoção de regras comuns para importação e exportação de produtos, ou em outras palavras, um tratamento comum em face de terceiros. Na União Aduaneira, o bloco econômico adquire personalidade jurídica de Direito Internacional Público, podendo, portanto, celebrar tratados com outros Estados ou Blocos Econômicos ${ }^{34}$.

\section{d) Mercado Comum}

O Mercado Comum representa uma versão mais ambiciosa da integração, pois à livre circulação de mercadorias acrescentam-se os demais fatores de produção - capital e trabalho - permitindo o livre estabelecimento e a livre prestação de serviços pelos profissionais, exigindo a adoção de políticas comuns, para evitar as diferenças no interior da zona que viessem a provocar desigualdades indesejáveis. Esta etapa de integração pressupõe a uniformização da legislação dos membros e uma coordenação de políticas macroeconômicas. Aqui há a

${ }^{34}$ Sobre o tema ver: GOMES, Eduardo Biacchi. Blocos Econômicos - Solução de Controvérsias, 2. ed. Curitiba: Juruá, 2005. 
supranacionalidade; funciona a regra da maioria, ou seja, ao se observar que uma legislação nacional não está conforme com as regras estabelecidas, o Estado terá que modificar a legislação em prol das regras comuns.

O conceito de Mercado Comum visa alcançar as cinco liberdades pelos Estados, caracterizadoras da integração econômica nacional e que conformam o respectivo Mercado. São elas: a primeira é a livre circulação de bens ${ }^{35}$, ou seja, o caminho para a conformação dessa liberdade passa pelo estabelecimento da união aduaneira, a partir de uma tarifa externa e uma política comercial comuns.

A segunda liberdade é a de estabelecimento e livre prestação de serviços ${ }^{36}$, assegurando a livre circulação de pessoas e, além disso, sua opção por se estabelecer ou prestar serviços em qualquer um dos Estados-membros, nas mesmas condições que os nacionais, sem qualquer discriminação referente à nacionalidade.

A terceira liberdade é a livre circulação de pessoas. Qualquer cidadão que pertença a um dos Estados-membros pode circular nos demais com total liberdade, sem ser submetido a controle nas fronteiras internas.

A quarta liberdade é a livre circulação de capitais, ou seja, deve ocorrer a possibilidade de o investidor colocar o capital onde o interesse dos produtos do empresário o dirija ${ }^{37}$.

35 Elisabeth Pinto de Almeida Accioly sustenta que esta "implica a abertura de fronteiras externas e o desmantelamento das barreiras alfandegárias para que os produtos passem a circular livremente entre os Estados que fazem parte do processo integrativo". (ACCIOLY, Elisabeth Pinto de Almeida. MERCOSUL \& União Européia - Estrutura Jurídico Institucional. Curitiba: Juruá, 1999. p. 60-61)

36 Elisabeth Accioly sustenta que "[...] os trabalhadores assalariados ou independentes de qualquer Estado-membro podem se deslocar livremente e procurar, onde melhor thes aprouver, um trabalho em condições idênticas àquelas que beneficiam os trabalhadores nacionais, traduzido na liberdade de estabelecimento, ou podem oferecer e prestar serviços a clientes de quaisquer Estadosmembros, nas mesmas condições que os nacionais do Estado de acolhimento, traduzido na livre prestação de serviços". (ACCIOLY, Elisabeth P. de. Ob. cit., p. 60)

37 Elisabeth Accioly argúi que "[...] qualquer operação relativa a importação - exportação, qualquer 
A quinta liberdade é a liberdade da concorrência, que submete todos os produtores desse país ou zona às mesmas regras de natureza econômica, administrativa, fiscal, política e social, isto é, todos se subordinam a uma disciplina jurídica e a encargos econômicas idênticos que vão incidir, da mesma maneira, nos produtos de sua empresa.

Em termos gerais, a concorrência ${ }^{38}$ é um mecanismo de base da economia de mercado, que garante refletirem os preços a relação real entre a procura e a oferta, necessárias para que a economia possa redistribuir os recursos de modo mais eficaz.

A União Européia passou por este patamar e está agregando novos fatores que a configurarão, no futuro, como uma união econômica monetária ${ }^{39}$.

\section{e) União Econômica e Monetária}

A união econômica representaria a união dos diferentes mercados nacionais em um único, o que implicaria, além das características de um Mercado Comum, a igualdade de tratamento das condições econômicas; com a união monetária, há a demanda à adoção de uma moeda única, ou em câmbios fixos e na convertibilidade obrigatória das moedas dos Países-membros, junto com as liberdades de mercado.

investimento destinado a permitir o estabelecimento de uma empresa na indústria, no comércio, nos serviços, qualquer prestação de serviços implicam, necessariamente, a disponibilidade de meio de pagamento que se impõe deixar circular livremente de país para país ao serviço das operações que o exercício dessas liberdades comporta". (ACCIOLY, Elisabeth P. de. Ob. cit., p. 61)

38 Elisabeth Accioly discorre que a concorrência significa "mais escolha para os consumidores, bem como preços mais baixos. A melhor garantia para os consumidores conseguirem obter bens e serviços de qualidade aos melhores preços é o fato de existirem vários fornecedores a competir. A concorrência livre e aberta constitui a pedra angular no sistema econômico do mercado". (ACCIOLY, Elisabeth P. de. Ob. cit., p. 61-62)

39 A chamada zona do euro inclui 14 Estados, dos 27 partícipes do Bloco. 
Ou seja, criar um mercado ampliado, mas que seja regido como se fosse o mercado de um só país, onde há um Banco Central Único ${ }^{40}$.

A criação de uma União Econômica e Monetária é um processo de aprofundamento econômico que, na essência, se caracteriza pela transferência da política monetária e cambial para o nível comunitário, com conseqüente perda de soberania por parte dos Estados-membros nesse domínio. Nela, há a efetiva integração das políticas macroeconômicas e a harmonização e aplicação definitiva da legislação comunitária pelos Países-membros ${ }^{41}$.

O MERCOSUL, embora mantendo ainda suas listas de exceções, princípio anterior, portanto, à área de livre comércio, é citado, usualmente, como exemplo, mesmo que incompleto, de União Aduaneira ${ }^{42}$, possuindo personalidade jurídica e já

40 Haroldo Malheiros Duclerc Verçosa discorre que, "examinando-se o Tratado de Maastricht e o Protocolo para o Estatuto do Sistema Europeu de Bancos Centrais, neles se verifica que o objetivo primário de um Banco Central seria aquele correspondente à estabilidade da moeda, do qual derivariam quatro tarefas básicas: a) definir e implementar a política monetária; b) realizar as operações internacionais de câmbio; c) custodiar e administrar as reservas em moeda estrangeira; e d) promover as operações do sistema de pagamentos". (VERÇOSA, Haroldo Malheiros Duclerc. Os regimes políticos e jurídicos dos Bancos Centrais. In: SZTAJN, Raquel (Coord.). Direito da Integração. São Paulo: Universidade Cidade de São Paulo, 2001. p. 152)

41 Em discurso proferido em 28 de maio de 2001, o ex-primeiro ministro francês Lionel Jospin, rejeitou a idéia de federação européia. Márcio Senne de Morais defende que o discurso teve o mérito de levantar questões cruciais sobre o futuro da União Européia: Qual é seu objetivo principal? Que tipo de União Européia política desejam os europeus? Os alemães defendem uma federação, os ingleses uma "Europa de nações livres, independentes e soberanas" e os franceses uma federação de Estados-nações, que permita que os países possam continuar a ser "atores na cena internacional". O Tratado de Lisboa, substituto da mal fadada Constituição Européia, silenciase sobre este aspecto. (SENNE DE MORAIS, Márcio. Jospin tem razões internas e externas. Folha de S. Paulo, 29 maio de 2001)

42 A este respeito, Umberto Celli Júnior sustenta que "não sem razão, o MERCoSUL costuma ser classificado como uma União Aduaneira imperfeita. Encontra-se estagnado, já que não se obteve sucesso na harmonização de políticas nacionais, há um déficit de incorporação de suas normas (resoluções e decisões) ao ordenamento jurídico de seus Estados-membros, principalmente por parte do Brasil e, sobretudo, existe uma quantidade inaceitável de listas de exceção à tarifa exterior comum. Não existe coordenação em matéria monetária, nem tampouco em matéria fiscal. A ausência de recursos também tem impossibilitado a integração física (construção de estradas, ferrovias, desenvolvimento de transportes em geral), que é fundamental para o escoamento das exportações". (CELLI JÚNIOR, Umberto. Teoria Geral da Integração: Em Busca de um Modelo Alternativo. In: MERCADANTE, Araminta (Org.) et al. Blocos Econômicos e Integração na América Latina, África e Ásia. Curitiba: Juruá, 2006. p. 32). Embora esteja previsto para 2008 o Código Aduaneiro Comum, que pode dar um plus no processo de harmonização das normas. 
tendo celebrado vários tratados com outros Estados e blocos econômicos ${ }^{43}$.

\section{O SURGIMENTO DO MERCOSUL ${ }^{44}$}

Para o MERCOSUL existir foi necessária a dissolução do Império Soviético. Apesar de tentativas anteriores do $A B C^{45}$, à época de Perón e Getúlio Vargas ${ }^{46}$, de Frondizi ${ }^{47}$ e Jânio Quadros, da ALALC (Associação Latino Americana de Livre Comércio) e da ALADI (Associação Latino Americana de Integração) ${ }^{48}$ estes dois últimos dentro do contexto do GATT-1947, mas, somente com a dissolução do império soviético é que se abriu real oportunidade para um realinhamento ${ }^{49}$, diminuindo a rivalidade regional.

A associação de fatores que vão desde a política de direitos humanos do governo Jimmy Carter, ao realinhamento econômico, sob a égide de uma só

${ }^{43}$ Com países o MERCOSUL tem Acordos-quadro com a Índia (Acordo de Comércio Preferencial MERCOSUL - Índia assinado em 25.01.2004 e 19.03.2005), com o Egito (assinado em 02.06.2004), com o Marrocos (assinado em 26.11.2004), com Israel (assinado em 08.12.2005). Com outros blocos econômicos o MERCOSUL tem acordos com a Comunidade Andina, a União Européia, a União Aduaneira da África Austral (SACU), o Acordo Quadro entre o MERCOSUL e o Conselho de Cooperação do Golfo (CCG), e a Associação Européia de Livre Comércio (AELC). Disponível em: <http://www.mre.gov.br/index>. Acesso em: 27 jan. 2008.

44 Adaptação, com modificações, do texto WINTER, Luís Alexandre Carta. A crise do modelo presidencialista no âmbito do MERCOSUL. Curitiba: Juruá, 2002. p. 81-87.

45 Argentina, Brasil e Chile, assinado, mas não ratificado, em 1915.

46 Com um "acordo secreto" entre Perón, Vargas e Ibaáñez, entre 1951 a 1954; sobre o tema ver ALMEIDA, Paulo Renan de. Pacto ABC - Raízes do MERCOSUL. Porto Alegre: EDIPUCRS, 1998.

47 Félix Luna sustenta que "Frondizi obteve uma formulação política cheia de audácia, ao acordar com o Presidente Jânio Quadros, em Uruguaiana, abril de 1961, uma série de medidas destinadas a unificar interesses econômicos, apresentar posições comuns na ordem interamericana e mundial e criar organismos de interesse comum". (LUNA, Félix. Argentina: de Perón a Lanusse (19431973). Rio de Janeiro: Civilização Brasileira, 1974. p. 127)

48 Criada em 12.08.1980, em seu artigo 24, possibilita a criação dentro dela mesma, de "sub-blocos".

49 Após a Revolução de 64 no Brasil, este, juntamente com a Argentina, reformulou o conceito de soberania, que não mais se fundaria nos limites e fronteiras geográficas dos Estados e sim no caráter político e ideológico dos regimes, de modo que as repúblicas americanas pudessem intervir, coletivamente, em qualquer outra, quando algum governo aceito como democrático estivesse ameaçado por movimento supostamente comunista ou de natureza semelhante. São as fronteiras ideológicas. Abandonada como doutrina no Governo de Costa e Silva, mas não significando que o Brasil toleraria um governo de esquerda revolucionária nos países vizinhos. Ver MONIZ BANDEIRA, Luiz Alberto. Estado Nacional e Política Internacional na América Latina. 2. ed. São Paulo: Ensaio, 1995. 
concepção dominante - que possibilita a realidade de um mundo globalizado, permitiu um retorno a governos democráticos.

No Brasil, José Sarney é eleito indiretamente pelo Congresso Nacional, na missão de completar a transição democrática. Encontrando-se na regência de uma conturbada política econômica, representada pelo não-cumprimento das metas e subseqüente suspensão do empréstimo do FMI, acrescido dos fracassos nos planos econômicos do ministro Dílson Funaro, termina por declarar moratória. A opção foi a aproximação com a Argentina de Raul Alfonsín.

Traumatizada pelo fracasso dos governos militares no campo econômico e social - este último, com a 'guerra suja' - e com a aventura militar ${ }^{50}$, uma Argentina, à época endividada e sem mercados para exportar dado o bloqueio da Comunidade Européia, solidária à Inglaterra, e pelo fato de os EUA terem produção agropastoril similar à sua, volta-se para o Brasil, em razão da ativa solidariedade existente entre ingleses e norte-americanos.

Sarney e Alfonsín assinam, em 1985, os 12 protocolos da Ata para Integração Brasileiro-Argentina, além de acordos sobre aviação militar e energia nuclear $^{51}$. Estes acordos aprofundaram entendimentos anteriores, ainda sob a égide do regime militar que acometia ambos os Estados ${ }^{52}$.

50 Na Guerra das Malvinas, quando o então Presidente da Junta Militar, Leopoldo Galtieri, tendo estreitado os laços com os EUA, "exportava assessores militares" para combater as guerrilhas na América Central supôs que os Estados Unidos o apoiassem tendo-se em vista os compromissos deste com o TIAR (Tratado Interamericano de Assistência Recíproca), o que acabou não acontecendo, por outro lado, supunha que ao abraçar uma causa nacional, "retomar" as ilhas Malvinas do domínio Inglês, estes não iriam defendê-la militarmente e, ao mesmo tempo, diminuiria a pressão que seu governo sofria por reformas. Errou em tudo. Morreram 800 argentinos e houve 1.300 feridos.

51 Segundo Odete Maria de.Oliveira, criou-se com este Tratado, um Grupo de Trabalho Conjunto, sob a responsabilidade das chancelarias brasileira e argentina, integrado por representantes da Comissão Nuclear de Energia Atômica (CNEA), argentina, e a Comissão Nacional de Energia Nuclear (CNEN), brasileira, e empresas nucleares visando ao fornecimento das relações entre os dois países nessa área, a promissão de seu desenvolvimento tecnológico nuclear e a criação de mecanismos que assegurem os superiores interesses da paz, da segurança e do desenvolvimento 
Em nova reunião em 17 de julho de 1987, Brasil e Argentina firmam o

Programa de Integração e Cooperação Econômica (PICE). Prevendo uma série de

anexos a vários Protocolos, na intenção de torná-los operativos, o relatório da

Comissão de Execução, de tão ousado, previu até mesmo a criação de uma moeda

comum, o "gaúcho", que embora não implantado, serve como referencial para o alto

grau de afinidade existente entre os dois presidentes.

O Tratado de Integração, Cooperação e Desenvolvimento entre o Brasil e a

Argentina $^{53}$ foi firmado em 7 de abril de 1988 e, já em 1990, temos a "Ata de Buenos

Aires", assinada em 6 de julho, segundo a qual Brasil e Argentina decidem

conformar um mercado comum. Porém, somente com o Acordo de Cooperação

Econômica n. 14, firmado em dezembro de 1990, em vigor em 01.01.1991, cujo teor

da região, sem prejuízo dos aspectos técnicos de cooperação nuclear que continuarão sendo regidos pelos instrumentos vigentes, que são os acordos de 1980 na mesma área. (OLIVEIRA, Odete Maria de. Os descaminhos do Brasil nuclear. Ijuí: Unijuí, 1999. p. 382)

52 "Os entendimentos entre Sarney e Alfonsín desdobraram, em certos aspectos, as negociações iniciadas por Figueiredo e Videla, e assentaram entre os dois países os alicerces da integração, não apenas econômica, mas também política e geopolítica, bastante mais profunda, em face tanto dos Estados Unidos e da Comunidade Econômica Européia quanto dos países da América do Sul, à medida que se propuseram a constituir novo pólo de gravitação, concorrendo para descongelar o sistema internacional de poder. Doravante, os dois países coordenariam suas políticas externas e agiriam solidariamente no âmbito internacional, como já o faziam no Grupo de apoio a Contadora, com o objetivo de conseguir uma solução pacífica e latino-americana para o problema da América Central, e na criação do consenso de Cartagena, que procurou unificar a posição do Continente vis-à-vis da questão da dívida externa. Outrossim, dentro desse contexto, empenharse-iam para oferecer à África, no outro lado do Atlântico Sul, uma alternativa econômica e política, a fornecer-Ihe manufaturas e, particularmente, gêneros alimentícios da Argentina, cujo acordo sobre o tricô com o Brasil já tendia a reduzir, sensivelmente, a dependência em que ela ficara da União Soviética, ao fecharem-se-Ihe os mercados da Comunidade Econômica Européia. A Argentina, que sob a ditadura advogava a aliança com a África do Sul, de pacto militar semelhante ao do Atlântico Norte (OTAN), sob a qual os Estados Unidos instalariam bases nas Malvinas, após a reconquista, e na Antártica, alinhou-se então com o Brasil e apoiou sua proposta, apresentada, em 1986, à Assembléia Geral da ONU, no sentido de desmilitarizar aquela região e a converter em uma zona de paz. E a pronta adesão do Uruguai, que, como país nodal, não tinha outra opção, completou o eixo Brasil-Argentina sobre a costa latino-americana do Atlântico Sul". (MONIZ BANDEIRA, Luiz Alberto. As relações regionais no Cone Sul: iniciativas de integração - História do Cone Sul. In: CERVO, Amado Luiz; RAPOPORT, Mário (Orgs.). Brasília: UnB, 1998. p. 330)

53 Segundo Haroldo Pabst, este "Tratado tinha como objetivo consolidar o processo de integração bilateral e instituir, numa primeira etapa, um espaço econômico comum no prazo máximo de 10 anos e a harmonização das políticas aduaneira, comercial, agrícola, industrial e de transporte e comunicações, assim como a coordenação de políticas monetárias, fiscal e cambiária; numa segunda etapa, proceder-se-ia à harmonização gradual das demais políticas necessárias à formação do mercado comum". (PABST, Haroldo. MERCOSUL - Direito da Integração. Rio Janeiro: Forense, 1997. p. 13) 
é em parte reproduzido pelo Tratado de Assunção ${ }^{54}$, tem-se as diretrizes para sua formação.

Entre 1986 e 1990, fatos importantes aconteceram para os futuros países signatários do Tratado de Assunção. A Argentina realiza suas eleições em oito de julho de 1989, novamente passa por severa crise política e econômica em um clima de extrema instabilidade, enfrentando rebeliões de caserna ${ }^{55}$ e com uma hiperinflação, elege um representante da oposição, o peronista Carlos Saúl Menem (1989-1995 e 1995-1999).

No Brasil, tem-se a Constituição de 1988 e eleições diretas para presidente em 1989; tal como na Argentina anteriormente, o clima é de crise econômica e hiperinflação. Elege-se Fernando Collor de Mello do inexpressivo Partido da Reconstrução Nacional (PRN), aparentemente alheio aos desgastados partidos tradicionais.

No Paraguai, em 1989, um golpe palaciano derruba o ditador Alfredo Stroessner, substituído pelo comandante da primeira divisão de cavalaria, General Andrés Rodrigues Pedotti, também pertencente ao partido Colorado, mas comprometido com a restauração democrática do País. E, finalmente, no Uruguai, a restauração democrática ocorrera um pouco antes, com o primeiro governo do Colorado Julio Maria Sanguinetti (1985-1990) sucedido pelo Blanco Luis A. Lacalle (1990-1995).

\footnotetext{
54 Sobre o tema ver BAPTISTA, Luiz Olavo. O MERCOSUL suas Instituições e Ordenamento Jurídico. São Paulo: LTr, 1998. p. 37; e BAPTISTA, Luiz Olavo; MERCADANTE, Araminta de Azevedo. MERCoSUL - Das Negociações a Implantação. São Paulo: LTr, 1994.

55 Só não há um efetivo clima para um golpe porque as forças armadas estavam desmoralizadas e o cenário mundial não era mais propício. Havia uma nova détente entre EUA e URSS.
} 
No plano continental, ressalta-se a "Iniciativa para as Américas", lançada em junho de 1990, pelo então Presidente George Bush ${ }^{56}$.

Assinado em 26 de março de 1991, pelos Presidentes Carlos Menem, pela Argentina, Fernando Collor de Mello, pelo Brasil, Andrés Rodrigues Pedotti, pelo Paraguai e Júlio Maria Sanguinetti, pelo Uruguai, o Tratado de Assunção começou a vigorar internacionalmente em 29 de novembro de 1991, com o depósito das ratificações. Pode-se afirmar que, estruturalmente, o Tratado de Assunção é um acordo programático.

\section{O TRATADO DE ASSUNÇÃO}

O Tratado de Assunção, estruturado dentro do modelo clássico do direito dos tratados, contendo preâmbulo, parte dispositiva, e anexos, foi assinado em Assunção, em 26 de março de 1991, pela Argentina, Brasil, Paraguai e Uruguai. Sua parte dispositiva é constituída por vinte e quatro artigos, divididos em seis capítulos. Possui cinco anexos, a saber: Anexo I trata do Programa de Liberalização Comercial, um cronograma para eliminar os gravames e demais restrições ao comércio recíproco. Anexo II trata do Regime Geral de Origem, visando estabelecer critérios de qualificação de origem dos produtos. Anexo III trata de um sistema de Solução de Controvérsias ${ }^{57}$. Anexo IV trata da Cláusula de Salvaguarda e, finalmente,

56 De acordo com PABST, Haroldo, ob. cit., p. 13, esta iniciativa destinava-se a acompanhar as transformações políticas e econômicas em curso na América Latina e oferecer uma nova modalidade de relacionamento dos EUA com a região, centrada no comércio, nos investimentos e na solução do problema da dívida, com vistas a chegar a uma zona de livre-comércio hemisférica, do Alasca à Terra do Fogo. Ver também GARCIA JÚNIOR, Armando Alvares em sua obra ALCA A Área de Livre Comércio das Américas. São Paulo: Aduaneiras, 1999. p. 19.

57 Modificado pelo Protocolo de Brasília e, mas tarde, pela criação de um Tribunal Permanente de Revisão (Protocolo de Olivos), com sede em Assunção. 
o Anexo V criou Subgrupos de Trabalho (reestruturados mais tarde pelo Protocolo de Ouro Preto).

Em seu preâmbulo, ressalta, com um linguajar próprio, as evoluções dos acontecimentos internacionais, como a consolidação dos espaços econômicos e que a integração é a resposta adequada a tais acontecimentos.

No artigo $1^{\circ}$, estabelece a constituição do mercado comum, até 31 de dezembro de 1994, denominado MERCOSUL, determinando, ainda, o que este Mercado Comum implicaria. O artigo $5^{\circ}$ determinou, durante o período de transição, mecanismos que viabilizariam o Mercado Comum.

Organicamente, o MERCOSUL se constituía dos seguintes órgãos: Conselho do Mercado Comum e Grupo do Mercado Comum. O primeiro, órgão superior e responsável pela condução política e tomada de decisões, é integrado pelos ministros de relações exteriores e ministros da economia, sendo que, uma vez por ano, reunir-se-á com a participação dos Presidentes dos Estados-Partes. O segundo é o órgão executivo do Mercado Comum, responsável, dentre outras coisas, pelo cumprimento das decisões do Conselho, e é coordenado pelos Ministérios das Relações Exteriores. O Grupo Mercado Comum poderá constituir subgrupos de trabalho (como de fato o foram, já que estavam, inclusive, previstos no Anexo V) e contará com uma Secretaria Administrativa, responsável pela guarda de documentos e comunicação das atividades.

O artigo 16 estabeleceu expressamente que durante o período de transição, tanto as decisões do Conselho quanto as do Grupo serão tomadas por consenso e com a presença de todos os Estados, ou seja, há a intergovernabilidade ${ }^{58}$. O artigo

58 Para Deisy Ventura, o fato de, "sendo o Conselho e o Grupo instituições intergovernamentais, não há transferência de competência da parte dos Estados em relação aos órgãos do MERCOSUL. A 
18 deu o prazo até 31 de dezembro de 1994 para constituir a estrutura institucional definitiva do bloco. A vigência do Tratado é indefinida, e aberto, após cinco anos, à adesão aos demais países da ALADI. O artigo 24 cria a Comissão Parlamentar Conjunta do MERCOSUL.

É interessante ressaltar que até estrutura institucional definitiva, dada, a princípio, pelo Protocolo de Ouro Preto, (com a ressalva do art. 47), o MERCOSUL tinha criado uma importante coletânea de decisões ${ }^{59}$.

\section{O PROTOCOLO DE OURO PRETO 60}

O Protocolo de Ouro Preto, em consonância com o que estabelecia o artigo 18 do Tratado de Assunção, deu uma nova estrutura institucional ao MERCOSUL. Contém preâmbulo, parte dispositiva, constituídos por 53 artigos, divididos em 12 capítulos e anexo, este relativo ao procedimento geral para reclamações perante a Comissão de Comércio do MERCOSUL.

Em seu preâmbulo, ele reafirma os objetivos do Tratado de Assunção e se propõe a adaptar a estrutura institucional do MERCOSUL. Em seu artigo $1^{\circ}$, apresenta a nova estrutura institucional do MERCOSUL, mantendo o Conselho do Mercado Comum (CMC) e o Grupo do Mercado Comum (GMC) ambos com atribuições ampliadas, e incluindo a Comissão de Comércio do MERCOSUL (CCM)

margem de manobra disponível aos parceiros é imensa, pois cabe a cada um deles a gestão dos compromissos assumidos em Assunção. Essa estrutura tão maleável já reflete uma abordagem nitidamente pragmática da integração, que repousa na esperança de que a evolução do processo determine o futuro da estrutura institucional definitiva do bloco". (VENTURA, Deisy, Assimetrias entre o MERCOSUL e a União Européia, São Paulo: Manole, 2003, p. 50)

60 Aprovado em Ouro Preto, em 17.12.1994, e entrou em vigor em 15.12.1995 (embora no Brasil, para efeitos internos, tenha entrado em vigor em 10.05.1996). Nos termos do direito dos tratados, protocolo é aquele tratado acessório, superveniente, mas às vezes simultâneo, no qual se pretende ou modificar, ou prorrogar, ou interpretar ou complementar outro tratado qualificável como principal. 
(com a função de assistir o GMC e responsável pela política comercial comum), a Comissão Parlamentar Conjunta (CPC) (com a finalidade de acelerar os procedimentos internos nos Estados-Partes) ${ }^{61}$, o Foro Consultivo Econômico-Social (FCES) $^{62}$ (órgão integrado pelos setores econômicos e sociais), agora como órgão ligado ao MERCOSUL, e não apenas ao Grupo Mercado Comum, uma Secretaria Administrativa (SAM), a cargo de um diretor, com mandato de dois anos eleito pelo GMC e designado pelo CMC.

Os órgãos, com capacidade decisória de natureza intergovernamental, continuam a ser o CMC que emitirá decisões, exercendo a titularidade da personalidade jurídica do MERCOSUL, e o GMC, que emitirá resoluções, acrescido da Comissão de Comércio do MERCOSUL, que emitirá diretrizes, depreendendo-se, portanto, que os demais órgãos sejam auxiliares e/ou consultivos. Os subgrupos de trabalho (SGT) continuam a existir, ainda vinculados ao GMC (por força do art. 14, V $)^{63}$ e são criados Comitês Técnicos (CT, subordinados à Comissão de Comércio, por força do art. $19, \mathrm{IX})^{64}$.

O Protocolo de Ouro Preto deu ao MERCOSUL personalidade jurídica, podendo o mesmo contratar, adquirir e vender bens, comparecer em juízo,

61 Substituído pelo Parlamento do MERCOSUL com competência ampliada em relação à Comissão Parlamentar Conjunta, em consonância com a Decisão 49/04 do CMC e efetivado em dezembro de 2006.

62 Também é um órgão consultivo, mas ligado ao GMC, criado pela Decisão 41/04, o Foro Consultivo de Municípios, Estados Federados, Províncias e Departamentos do MERCOSUL (FCCR).

63 São em número de 14, a saber: SGT 01 Comunicações, SGT 02 Aspectos institucionais, SGT 03 Regulamentos Técnicos e Avaliação de Conformidade, SGT 04 Assuntos Financeiros, SGT 05 Transportes e Infra-Estrutura, STG 06 Meio Ambiente, SGT 07 Indústria, SGT 08 Agricultura, SGT 09 Energia, SGT 10 Assuntos Trabalhistas, Emprego e Seguridade Social, SGT 11 Saúde, SGT 12 Investimentos, SGT 13 Comércio Eletrônico, SGT 15 Mineração.

64 São em número de 8, a saber: CT 1 Tarifas, Nomenclatura e Classificação de Mercadorias, CT 2 Assuntos Aduaneiros, CT 3 Normas e Disciplinas Comerciais, CT 4 Políticas Públicas que Distorcem a Competitividade, CT 5 Defesa da Concorrência, CT 6 Comitê de Estatísticas e Comércio Exterior do MERCOSUL, CT 7 Defesa do Consumidor e, o Comitê de Defesa Comercial e Salvaguardas (CDCS). 
conservar fundos e fazer transferências (arts. 34 e 35). As decisões ainda serão tomadas por consenso, com a presença de todos os Estados-Partes (art. 37) ${ }^{65}$.

Duas inovações importantes do Protocolo foram seus Capítulos IV, aplicação interna das normas emanadas dos órgãos do MERCOSUL e $\mathrm{V}$, fontes jurídicas do MERCOSUL. O primeiro, respeitando o processo legislativo interno de cada EstadoParte voltado para incorporação ao ordenamento jurídico nacional das normas do MERCOSUL, cria os mecanismos para que as mesmas entrem em vigor simultaneamente nos Estados-Partes. O segundo classifica as fontes jurídicas do MERCOSUL. Manteve-se o sistema de solução de controvérsias do Protocolo de Brasília (substituído pelo Protocolo de Olivos). Estabeleceu-se um orçamento para a Secretaria Administrativa. O artigo 47 previu a possibilidade de alteração da estrutura institucional e revogou as disposições do Tratado de Assunção que conflitassem com o Protocolo (art. 53). Calcado no artigo 47, do POP, durante os anos que se seguiram o MERCOSUL passou por uma série de modificações estruturais.

\section{A ATUAL ESTRUTURA INSTITUCIONAL DO MERCOSUL}

A estrutura apresentada hoje pelo MERCOSUL ${ }^{66}$ contém razoáveis modificações criadas após o Protocolo de Ouro Preto, no sentido de melhor atender o projeto a que se propõe.

65 Deisy Ventura relata que "somente a Argentina admitiu a possibilidade de adoção de voto por maioria qualificada ou maioria simples. Os demais parceiros propuseram simplesmente a manutenção do consenso, silenciando o Brasil sobre a necessidade da presença de todos os Estados Partes". (VENTURA, Deisy. Ob. cit., p. 79)

${ }^{66}$ Disponível em: <www.mercosur.int/msweb/portal>. Acesso em: 24 jan. 2008. 
Atualmente, o MERCOSUL, estruturalmente, é composto do Conselho do Mercado Comum, Grupo Mercado Comum, Comissão de Comércio do MERCOSUL, Foro Consultivo Econômico-Social, Secretaria do MERCOSUL, Tribunal Permanente de Revisão do MERCOSUL, Tribunal Administrativo-Laboral do MERCOSUL, o Centro MERCOSUL de Promoção do Estado de Direito e o Parlamento do MERCOSUL.

O Conselho Mercado Comum passou a contar com considerável aparato especializado, fruto do aprofundamento do processo de integração, buscando uma harmonização nas legislações dos Estados-Membros. Atualmente, estão ligados ao Conselho do Mercado Comum, as Reuniões Ministeriais ${ }^{67}$ com suas comissões, comitês, grupos de trabalho e grupos gestores, o Foro de Consulta e Concertação Política (FCCP) ${ }^{68}$, a Comissão de Representantes Permanentes do MERCOSUL (CRPM), a Reunião de Altas Autoridades na área de Direitos Humanos (RADDHH) ${ }^{69}$, o Foro Consultivo de Municípios, Estados Federados, Províncias e Departamentos do MERCOSUL (FCCR), e os seguintes Grupos: Grupo de Alto Nível de Estratégia do MERCOSUL de Crescimento de Emprego (GANEMPLE), Grupo Alto Nível para Examinar a Consistência e Dispersão da Tarifa Externa Comum (GANAEC), Grupo

67 Agricultura, Cultura, Economia e Presidentes dos Bancos Centrais, Educação, Indústria, Interior, Saúde, Trabalho, Turismo. O da Cultura, Educação e Interior, são coordenadas pelo Foro de Consulta e Concertação Política (FCCP)

68 Que abarca o Grupo de Trabalho sobre Armas de Fogo e Munições, o Grupo de Trabalho sobre Assuntos Jurídicos e Consulares, e o Grupo Ad Hoc sobre Registro Comum de Veículos Automotores e Motoristas.

69 Coordenada pelo FCCP e engloba o Grupo de Trabalho Permanente para a Coordenação e Implementação das Ações relativas a Iniciativa para a Promoção e Proteção dos Direitos da Infância e Adolescência (GTP-Niñ@Sur), Grupo de Trabalho ad hoc sobre Direitos Econômicos, Sociais e Culturais (GT-DESC), Grupo de Trabalho sobre Promoção da Igualdade Racial (GTPIR), Grupo de Trabalho sobre Educação e Cultura em Direitos Humanos (GT- ECDH) e o Grupo de Trabalho encarregado do Desenvolvimento e Implementação do Instituto de Políticas Públicas de Direitos Humanos (GT-INSTPPDH). 
Ad Hoc de Alto Nível para a Reforma Institucional (GANRI), Grupo de Alto nível para a elaboração de um Plano Estratégico para a Superação das Assimetrias no MERCOSUL (GANASIM), Grupo de Trabalho para a negociação do processo de adesão da República Bolivariana da Venezuela (GTVENE), e o Grupo de Trabalho Ad Hoc para a incorporação da República da Bolívia como Estado-Parte do MERCOSUL (GTBO).

Com relação ao Grupo Mercado Comum, ao lado dos sub-grupos de trabalho, com suas várias comissões, subcomissões grupos ad hoc e grupos, estão ligados a ele o Instituto MERCOSUL de Formação (IMEF) ${ }^{70}$, o Grupo Ad-Hoc de Especialistas do "Fundo para Convergência Estrutural do MERCOSUL" (GAHEFOCEM) ${ }^{71}$, o Grupo de Contratações Públicas do MERCOSUL (GCPM), Grupo de Serviços (GS), Comissão Sócio-Laboral do MERCOSUL (CSLM), Comitê Automotor (CA), Comitê de Cooperação Técnica do MERCOSUL (CCT), o Foro Consultivo de Municípios, Estados Federados, Províncias e Departamentos do MERCOSUL $(\text { FCCR })^{72}$, Grupo de Assuntos de Competência da SAM (GAP), os Grupos Ad Hoc, do Código Aduaneiro do MERCOSUL (GAHCAM), de Consulta e Coordenação para as Negociações OMC e SGPC (GAH OMS-SGPC), Relacionamento Exterior (GAHRE), Sanitário e Fitossanitário (GAHSF), Açucareiro (GAHAZ), Biotecnologia Agropecuária (GAHABA), Comércio de Cigarros no MERCOSUL (GAHACC), Integração Fronteiriça (GAHIF), Integração Produtiva no MERCOSUL (GAHIP), Biocombustíveis (GAHB), Domínio MERCOSUL (GAHDM), o Grupo de Trabalho sobre Fundo MERCOSUL de Apoio a Pequenas e Médias Empresas (GTFAPME),

70 Coordenado pela CRPM, ligado ao CMC.

${ }^{71}$ Idem.

72 Abarcando o Comitê dos Estados Federados, Províncias e Departamentos (CEFPD) e o Comitê dos Municípios (CM). 
além das Reuniões Especializadas ${ }^{73}$ (estas, também, com suas comissões técnicas e grupos).

A Comissão de Comércio do MERCOSUL continuou com seus Comitês Técnicos.

O Fundo Consultivo Econômico-Social, na busca de trazer o setor produtivo à proposta do Tratado de Assunção e seus Protocolos atua nas seguintes áreas temáticas: Aspectos Sociais da Integração (CASI), Consolidação da União Aduaneira (CCUA), Aprofundamento do Processo de Integração (CPPI), Relações Externas do MERCOSUL (CREM) e o Comitê Misto CES-FCES (CES-FCES).

A Secretaria do MERCOSUL, mantendo as funções previstas no Protocolo de Ouro Preto, teve sua estrutura modificada e modernizada pela Dec. 07/07, da CMC, passando a contar com uma estrutura organizacional permanente, com normas para seleção e contratação de pessoal, e, finalmente, uma estrutura salarial. A chefia da Secretaria passa a estar nas mãos de um Diretor, assistido por um Coordenador e terá um quadro funcional de, no máximo, 40 funcionários, respeitado o princípio do equilíbrio na representação das nacionalidades dos Estados Partes. A Secretaria é integrada por quatro setores: Administração, Apoio, Assessoria Técnica e, Normativa, Documentação e Divulgação. É também de responsabilidade da Direção da Secretaria a Unidade Técnica do Focem (Fundo para Convergência Estrutural do MERCOSUL).

O Tribunal Permanente de Revisão do MERCOSUL (TPR), criado pelo Protocolo de Olivos em 18.02.2002 e instalado em Assunção em 13.08.2004, tem por competência servir como instância superior das decisões dos laudos do Tribunal

73 Em siglas, são elas: REAF (com cinco grupos temáticos), RECAM, RED (coordenada pela FCCP, com quatro comissões técnicas), RECYT (com duas comissões técnicas), RECS, RECM, REDPO, 
Arbitral Ad Hoc e é integrado por cinco árbitros. Cada Estado-Parte do MERCOSUL designará um árbitro e um suplente por um período de dois anos, renovável por dois períodos subseqüentes. O quinto árbitro é designado por um período de três anos, não renováveis. A Resolução 66/05 GMC, criou uma Secretaria para o Tribunal Permanente de Revisão. O Secretário terá um mandato de dois anos, prorrogável por uma única vez e será exercido de forma rotativa.

O Tribunal Administrativo-Laboral do MERCOSUL, criado em 2002 tem a função específica de resolver conflitos de natureza trabalhista do pessoal ligado à Secretaria do MERCOSUL e a outros órgãos dentro da estrutura institucional do MERCOSUL. É integrado por quatro membros titulares de cada um dos Estados Parte, designados pelo Grupo Mercado Comum, por um período de dois anos, renováveis por uma vez. Sua sede é em Montevidéu.

O Centro MERCOSUL de Promoção do Estado de Direito (CMPED), criado pela Decisão 24/04 CMC, engloba o Observatório da Democracia no MERCOSUL $(\mathrm{ODM})^{74}$, conforme Decisão 05/07 CMC. O Centro tem por finalidade principal, nos termos de seu artigo $1^{\circ}$, analisar e reforçar o desenvolvimento do Estado, a governabilidade democrática e todos os aspectos vinculados aos processos de integração regional. Para cumprir esse objetivo, promoverá conferências, seminários, foros, publicações, reuniões de acadêmicos, representantes governamentais e da sociedade civil, promoverá cursos de capacitação, programas de intercâmbio, oferta de bolsas de estudos e biblioteca. Sua sede é em Assunção, junto ao Tribunal Permanente de Revisão.

REII, REJ, REM, REMPM, REOGCI, REPCCM, RET, REEG (coordenado pela FCCP) e RTIN.

74 O Observatório coordenado conjuntamente pelo CEMPED e pela Comissão de Representantes Permanentes do MERCOSUL (CRPM) tem a função de contribuir para o fortalecimento dos objetivos do Protocolo de Ushuaia sobre Compromisso Democrático no MERCOSUL, Bolívia e 
O Parlamento do MERCOSUL, que substituiu a Comissão Parlamentar Conjunta, tem sua origem remota na Decisão 26/03 do CMC, que aprovou 0 "Programa de Trabalho do MERCOSUL 2004-2006"75, e que tinha como um dos objetivos a constituição de um Parlamento do MERCOSUL. A Decisão 49/04 do CMC dá continuidade à criação do Parlamento do MERCOSUL, investindo a Comissão Parlamentar Conjunta na qualidade de comissão preparatória. Finalmente, a Decisão 23/05 do CMC cria o Parlamento do MERCOSUL. Sua sede é em Montevidéu, sendo um órgão unicameral, devendo reunir-se, pelo menos uma vez por mês e, passado o período de transição, será composto por representantes eleitos por sufrágio universal, direto e secreto, eleitos em um mesmo dia, com mandato de quatro anos, podendo ser reeleitos. Sua competência vai desde fazer cumprir as normas do MERCOSUL e a preservação do regime democrático, o quê, para tanto, elaborará anualmente relatórios sobre a situação dos direitos humanos nos Estados Partes, até emitir pareceres, fazer projeto e anteprojeto de normas, fazer declarações, recomendações, relatórios.

Mesmo antes da modificação da estrutura original do MERCOSUL, havia uma preocupação em relação ao processo de integração e sua internalização ${ }^{76}$, tendo, como próximo passo, criar mecanismos de internalização das normas oriundas dos órgãos nos Estados-Partes.

Chile, acompanhar os processos eleitorais nos Estados Partes do MERCOSUL, e realizar atividades e estudos vinculados à consolidação da democracia na região.

75 Previsto em seu Anexo, item 3.1.

76 Deisy Ventura salienta que "um estudo do Ministério das Relações Exteriores do Brasil mostra que o isolamento dos Parlamentos Nacionais em relação ao processo de integração não é uma diletante tese acadêmica. Nesse documento o Brasil relata a incorporação de 78 Decisões do Conselho e de 345 Resoluções do Grupo, tomadas até dezembro de 1995. Entre as Decisões, $14.1 \%$ foram submetidas à aprovação do Poder Legislativo; 30,7\% originaram atos administrativos; e 44,8\% não engendraram nenhuma medida nacional de aplicação Entre as Resoluções, nenhuma foi enviada ao Parlamento; $42,3 \%$ foram incorporadas via administrativa e $33.62 \%$ não foram transpostas". (VENTURA, Deisy. Ob. cit., p. 153) 


\section{CAPÍTULO II}

\section{O PROCESSO DE INTERNALIZAÇÃO DAS NORMAS}

As normas do MERCOSUL, salvo aquelas de estrita competência de seus órgãos, em que, na própria Decisão, há um artigo que dispensa a necessidade da internalização da norma nos Estados-Partes (como a que criou a Secretaria do Tribunal de Revisão), determinam que estes "internalizem" as normas dentro de seu ordenamento jurídico, segundo a sistemática adotada por suas leis nacionais. Como o critério adotado pelo Protocolo de Ouro Preto (POP) é o consenso (art. 37), uma norma aprovada pelos órgãos do MERCOSUL só terá vigência quando aprovada pelos parlamentos de todos os Estados-Membros (inteligência do art. 40, do POP).

O que significa dizer que o MERCOSUL é uma organização internacional regional dentro das regras do direito internacional público. Suas normas são de integração e necessitam da aprovação dos Parlamentos nacionais para terem vigência e eficácia dentro do território dos Estados-Partes, embora, reconheça-se que, em razão de acordos que envolveram órgãos técnicos dos Estados-Partes, tenham sido adotados padrões comuns ${ }^{77}$, mas, ainda assim, o foi por consenso. $\mathrm{O}$ artigo 42 do POP deixava isso bem claro ao dispor que "as normas (decisões, resoluções e diretivas) terão caráter obrigatório e quando for necessário, deverão ser incorporadas aos ordenamentos jurídicos nacionais mediante os procedimentos previstos pela legislação de cada país".

77 Como, por exemplo, as questões de freqüências do serviço móvel celular (Res. 19/01 GMC), emissões filatélicas com temática comum MERCOSUL (Res. 48/00 GMC) ou ainda marco regulatório para serviço de radiodifusão em freqüência modulada FM (Res. 31/01 GMC). Sobre o tema ver CANÇADO TRINDADE, Otávio Augusto Drummond. O MERCOSUL no Direito Brasileiro. Belo Horizonte: Del Rey, 2006. p. 100-101. 
Ao largo da discussão dualista, e monista, com suas vertentes, cada um dos

Estados-Partes do MERCOSUL tem seus procedimentos.

As normas do MERCOSUL, como normas de direito internacional público, seguem, por conseguinte, a tradicional divisão do direito dos tratados no que concerne sua elaboração, qual seja, há a negociação, assinatura, ratificação, promulgação, publicação e o registro ${ }^{78}$.

A competência pela negociação e assinatura (por plenipotenciário), em todos os Estados-Partes do MERCOSUL, será do Executivo.

No processo de ratificação, há a divisão de competência entre o poder executivo e o poder legislativo; aqui, há a própria aplicação do processo de internalização da lei(junto com a promulgação e a publicação), não adotando, os Estados-Partes originais, no que concerne a isso, sistemas muito diferentes ${ }^{79}$.

A Constituição argentina, por exemplo, em seu artigo 75, deu competência ao Congresso para aprovar tratados que terão hierarquia superior às leis, mas, para

78 Este, por força do art. 102 da Carta da ONU.

79 Mirtô Fraga fez uma interessante análise entre tratado e lei. "São, ambas, lei, no sentido amplo de fonte de direito. As fontes internas recebem várias denominações (Constituição, lei constitucional, lei federal ordinária, decreto etc.), do mesmo modo que a externa (tratado, convenção, ajusto, acordo, pacto). Para as diversas espécies de fonte interna, bem como para a fonte externa, a Constituição estabeleceu processos de formação distintos, embora haja pontos comuns entre eles. Os órgãos encarregados de elaborar a lei (sentido estrito), por exemplo, devem, sempre, ser ouvidos na formação do tratado, manifestando sua aprovação que, em síntese, é a autorização ao Executivo, para concluí-lo, com a ratificação, e é, também, aquiescência à matéria nele contida. $\mathrm{A}$ aprovação do tratado pelo Congresso Nacional segue a mesma tramitação da discussão e aprovação da lei (sentido estrito) e do decreto legislativo. E, após sua conclusão, como toda fonte de direito positivo (constituição, tratado, lei etc.) deve ser promulgado. A diferença é que se, em um determinado caso, não interessa ao Governo respeitar o compromisso, se o Tribunal entende ser a aplicação da norma convencional contrária aos interesses nacionais, pode-se, nesse caso, aplicar a lei, afastando-se o tratado. Aí, entretanto, a decisão é política e não jurídica e não exime o Brasil (ou qualquer outro País) de responsabilidade por danos oriundos de tal procedimento. Para evitá-la, deve denunciar o tratado". (FRAGA, Mirtô. O Conflito entre Tratado Internacional e Norma de Direito Interno. Rio de Janeiro: Forense, 1998. p. 94-97) 
isso, necessitarão de um quorum especial ${ }^{80}$; fora dessa situação, o processo

legislativo argentino está disposto no artigos 77 a 84. Em relação ao Executivo, compete ao Presidente da Nação Argentina, na forma do artigo 99, 11, concluir e firmar tratados ${ }^{81}$.

No Brasil, relativamente aos tratados, participam o Poder Executivo, por força

do artigo 84, VIII ${ }^{82}$, e o Poder Legislativo, nos termos do artigo 49, ${ }^{83}$, da Constituição

80 "Art. 75. Corresponde al Congreso: [...] 22 - Aprobar o desechar tratados concluidos con las demás naciones y con las organizaciones internacionales y los concordatos con la Santa Sede. Los tratados y concordatos tienen jerarquía superior a las leyes. La Declaración Americana de los Derechos y Deberes del Hombre; la Declaración Universal de Derechos Humanos; la Convención Americana sobre Derechos Humanos; el Pacto Internacional de Derechos Económicos, Sociales y Culturales; el Pacto Internacional de Derechos Civiles y Políticos y su Protocolo Facultativo; la Convención sobre la Prevención y la Sanción del Delito de Genocidio; la Convención Internacional sobre la Eliminación de todas las Formas de Discriminación Racial; la Convención sobre la Eliminación de todas las Formas de Discriminación contra la Mujer; la Convención contra la Tortura y otros Tratos o Penas Crueles, Inhumanos o Degradantes; la Convención sobre los Derechos del Niño; en las condiciones de su vigencia, tienen jerarquía constitucional, no derogan artículo alguno de la primera parte de esta Constitución y deben entenderse complementarios de los derechos y garantías por ella reconocidos. Sólo podrán ser denunciados, en su caso, por el Poder Ejecutivo nacional, previa aprobación de las dos terceras partes de la totalidad de los miembros de cada Cámara. Los demás tratados y convenciones sobre derechos humanos, luego de ser aprobados por el Congreso, requerirán del voto de las dos terceras partes de la totalidad de los miembros de cada Cámara para gozar de la jerarquía constitucional. [...]

[...] 24 - Aprobar tratados de integración que deleguen competencias y jurisdicción a organizaciones supraestatales en condiciones de reciprocidad e igualdad, y que respeten el orden democrático y los derechos humanos. Las normas dictadas en su consecuencia tienen jerarquía superior a las leyes. La aprobación de estos tratados con Estados de Latinoamérica requerirá la mayoría absoluta de la totalidad de los miembros de cada Cámara. En el caso de tratados con otros Estados, el Congreso de la Nación, con la mayoría absoluta de los miembros presentes de cada Cámara, declarará la conveniencia de la aprobación del tratado y sólo podrá ser aprobado con el voto de la mayoría absoluta de la totalidad de los miembros de cada Cámara, después de ciento veinte días del acto declarativo. (grifo nosso)

La denuncia de los tratados referidos a este inciso, exigirá la previa aprobación de la mayoría absoluta de la totalidad de los miembros de cada Cámara (...)". Disponível em: <http://www.diputa dos.gov.ar/>. Acesso em: 25 jan. 2008.

81 "Art. 99. 11.- Concluye y firma tratados, concordatos y otras negociaciones requeridas para el mantenimiento de buenas relaciones con las organizaciones internacionales y las naciones extranjeras, recibe sus ministros y admite sus cónsules".

82 "Art. 84. Compete privativamente ao Presidente da República:

VIII - celebrar tratados, convenções e atos internacionais, sujeitos a referendo do Congresso Nacional;"

83 "Art. 49. É da competência exclusiva do Congresso Nacional:

I - resolver definitivamente sobre tratados, acordos ou atos internacionais que acarretem encargos ou compromissos gravosos ao patrimônio nacional;" 
de $1988^{84}$. O processo legislativo está previsto no artigo 59 ao artigo 69. Há, uma hierarquização das normas, prevista no artigo 59, e não havia, até a Ementa Constitucional $45 / 04^{85}$, uma previsão de valoração dos tratados internacionais, o que conduziu, por uma construção pretoriana ${ }^{86}$, que estes tivessem a equivalência de uma norma ordinária. Atualmente, os tratados internacionais que versarem sobre direitos humanos são erigidos a condição equivalente a uma Emenda Constitucional, ainda, portanto, infra-constitucional. Esta questão já se constata no próprio no parágrafo único do art. $4^{\circ}$, da Constituição de 88 , ao fazer-se remissão a uma comunidade latino-americana de nações, mas, em termos de integração, ou seja, dentro da órbita do direito internacional público ${ }^{87}$.

No Paraguai, sua Constituição de 1992, analisando-se os artigos 137, primeira parte ${ }^{88}, 141^{89}$ e $145^{90}$, constata-se que, a exemplo da Constituição argentina, admite a existência de uma ordem jurídica supranacional, desde que o país faça

${ }^{84}$ Considerando que potencialmente todos os tratados possam gerar gravames, mesmo que ínfimos, não há que se falar de acordos executivos (tratados que excluem a participação do Poder Legislativo).

85 De 08.12.2004. Em seu art. 50, § $3^{\circ}$ - "Os tratados e convenções internacionais sobre direitos humanos que forem aprovados, em cada Casa do Congresso Nacional, em dois turnos, por três quintos dos votos dos respectivos membros, serão equivalentes às emendas constitucionais".

${ }^{86} \mathrm{O}$ art. 102, III, "b", da CF, atribui ao STF competência para declarar a inconstitucionalidade de tratado ou lei federal.

87 "Art. $4^{\circ}$. Parágrafo único. A República Federativa do Brasil buscará a integração econômica, política, social e cultural dos povos da América Latina, visando à formação de uma comunidade latino-americana de nações".

88 "Artículo 137. DE LA SUPREMACIA DE LA CONSTITUCION La ley suprema de la República es la Constitución. Esta, los tratados, convenios y acuerdos internacionales aprobados y ratificados, las leyes dictadas por el Congreso y otras disposiciones jurídicas de inferior jerarquía, sancionadas en consecuencia, integran el derecho positivo nacional en el orden de prelación enunciado". Disponível em: <http://pdba.georgetown.edu/Constitutions/Paraguay/para1992.html>. Acesso em: 25 jan. 2008.

89 "Artículo 141. DE LOS TRATADOS INTERNACIONALES Los tratados internacionales validamente celebrados, aprobados por ley del Congreso, y cuyos instrumentos de ratificación fueran canjeados o depositados, forman parte del ordenamiento legal interno con la jerarquía que determina el Artículo 137".

90 "Artículo 145. DEL ORDEN JURIDICO SUPRANACIONAL La República del Paraguay, en condiciones de igualdad con otros Estados, admite un orden jurídico supranacional que garantice la vigencia de los derechos humanos, de la paz, de la justicia, de la cooperación y del desarrollo, en lo político, económico, social y cultural.

Dichas decisiones sólo podrán adoptarse por mayoría absoluta de cada Cámara del Congreso". 
parte dessa estrutura política e que isso tenha sido aprovado pela maioria absoluta de cada uma das Câmaras de seu Congresso. Cabe ao Senado a aprovação de tratados internacionais ${ }^{91}$ e ao Presidente negociar e firmar tratados internacionais ${ }^{92}$. O processo legislativo paraguaio está previsto nos artigos 203 ao 215.

No Uruguai, sua Constituição de 1997, em seu artigo 6ª a exemplo do art. $4^{\circ}$, parágrafo único da Constituição Brasileira, faz remissão ao processo de integração ${ }^{93}$, dentro, portanto, da esfera do direito internacional público, não prevendo qualquer dispositivo supranacional e seu processo legislativo está previsto entre os artigos 133 ao artigo 146. Compete ao Poder Executivo celebrar tratados necessitando, contudo a aprovação do Poder Legislativo ${ }^{94}$.

Com o intuito de dar ao MERCOSUL um status diferente de outros tratados internacionais assinados pelos Estados-Partes, bem como tentando suprir uma lacuna existente no Tratado de Assunção e no Protocolo de Ouro Preto, o Protocolo Constitutivo do Parlamento do MERCOSUL, em seu artigo 4, 12, estabeleceu um processo legislativo determinando que os projetos deverão ser encaminhados ao Parlamento pelo órgão decisório do MERCOSUL, antes de sua aprovação. Se

91 "Artículo 224. DE LAS ATRIBUCIONES EXCLUSIVAS DE LA CAMARA DE SENADORES Son atribuciones exclusivas de la Cámara de Senadores: 1. iniciar la consideración de los proyectos de ley relativos a la aprobación de tratados y de acuerdos internacionales".

92 "Artículo 238. DE LOS DEBERES Y DE LAS ATRIBUCIONES DEL PRESIDENTE DE LA REPUBLICA Son deberes y atribuciones de quien ejerce la presidencia de la República: 7 . el manejo de las relaciones exteriores de la República. En caso de agresión externa, y previa autorización del Congreso, declarar el Estado de Defensa Nacional o concertar la paz; negociar y firmar tratados internacionales; recibir a los jefes de misiones diplomáticas de los países extranjeros y admitir a sus cónsules y designar embajadores, con acuerdo del Senado;"

93 "Artículo $6^{\circ}$. En los tratados internacionales que celebre la República propondrá la cláusula de que todas las diferencias que surjan entre las partes contratantes, serán decididas por el arbitraje u otros medios pacíficos. La República procurará la integración social y económica de los Estados Latinoamericanos, especialmente en lo que se refiere a la defensa común de sus productos y materias primas. Asimismo, propenderá a la efectiva complementación de sus servicios públicos". Disponível em: <http://www.rau.edu.uy/uruguay/const97-7.11.htm>. Acesso em: 25 jan. 2008.

94 "Artículo168. Al Presidente de la República, actuando con el Ministro o Ministros respectivos, o con el Consejo de Ministros, corresponde: 20) Concluir y suscribir tratados, necesitando para ratificarlos la aprobación del Poder Legislativo". Disponível em: <http://www.rau.edu.uy/uruguay/ const97-7.11.htm>. 
aprovado pelo órgão decisório, de acordo com os termos do parecer do Parlamento, a norma deverá ser enviada pelo Poder Executivo nacional ao seu respectivo Parlamento, dentro do prazo de quarenta e cinco dias, contados de sua aprovação. Nos casos em que a norma aprovada não estiver de acordo como o parecer do Parlamento ou este não tiver se manifestado, a norma seguirá o trâmite ordinário de incorporação. O Protocolo prevê que os Parlamentos nacionais deverão adotar medidas necessárias para a celeridade de normas do MERCOSUL que tenham sido adotadas com parecer favorável do Parlamento do MERCOSUL, que, adotadas, possibilitarão a vigência da norma no prazo de até 180 dias, contados do ingresso da mesma no respectivo Parlamento nacional. Visando dar celeridade ao processo de internalização das normas dentro dos Estados-Partes, o Parlamento elaborará pareceres sobre todos os projetos de normas do MERCOSUL que requeiram aprovação legislativa em um ou vários Estados Partes no prazo de noventa dias a contar da consulta ${ }^{95}$.

Apesar dessa nova possibilidade que se vislumbra, o fato é que, em todos os Estados-Partes do Tratado de Assunção, há a consagração do Poder Executivo como principal fonte de iniciativa normativa, ou seja, nada acontecerá se não houver a vontade política do Chefe de Estado e de Governo, vez que o sistema adotado é o presidencialista.

95 Otávio Cançado Trindade lembra que anteriormente ao Protocolo, no Brasil "o Grupo Interministerial criado para estudar formas de aperfeiçoamento da sistemática de internalização das normas do MERCOSUL chegou a elaborar projeto de lei nesse sentido. Pretendia-se incorporar as normas MERCOSUL ao direito brasileiro mediante a simples publicação do ato internacional no Diário Oficial, sem necessidade de qualquer ato normativo interno para tanto. $\mathrm{O}$ procedimento se assemelharia à aplicabilidade direta. Contudo, a idéia não prosperou. Em primeiro lugar, porque o projeto de decreto não definia claramente a hierarquia que as normas MERCOSUL gozariam no direito brasileiro. Em segundo lugar, porque persistiam dúvidas quanto à constitucionalidade da Ementa 32, fundamento legal para o referido decreto". (CANÇADO TRINDADE, Otávio. Ob. cit., p. 144-146) 
SEGUNDA PARTE

\section{O SISTEMA PRESIDENCIALISTA}

\section{CONTEXTUALIZAÇÃO ${ }^{96}$}

Em vinte e seis de março de 2008, o Mercado Comum do Sul, mais conhecido como MERCOSUL, completou dezessete anos. O projeto inicial era ambicioso e, pela vontade de seus governantes, determinava datas rígidas para seu avanço a começar da zona de livre comércio, caminhando para uma união aduaneira e culminando com o mercado comum. Contudo, desde o início, o MERCOSUL esteve rigidamente subordinado aos humores dos governantes dos quatro países seus formadores.

Discutir integração econômica é também discutir o significado e a proteção que a formação de blocos econômicos, eventualmente, possam dar aos Estados, em um mundo globalizado.

Pensar o modelo de bloco econômico implantado no âmbito do MERCOSUL é ressaltar a peculiaridade de ser o único bloco formado unicamente por países de sistema presidencialista ${ }^{97}$, aspecto este nodal na relação entre os membros do bloco.

Criar um bloco econômico entre países que adotam como sistema de governo, o presidencialismo, constitui uma experiência única e sem paralelo com os

96 Adaptação, com modificações, do texto WINTER, Luís Alexandre Carta. A crise do modelo presidencialista no âmbito do MERCOSUL. Curitiba: Juruá, 2002. p. 1-3.

97 No presidencialismo a chefia de Estado e de Governo serão exercidas pela mesma pessoa, o Presidente. Em todos os outros blocos econômicos, há, ou uma participação presidencialista e parlamentarista (chefe de Estado é uma pessoa e chefe de Governo é outra), como no NAFTA, acordo de livre comércio entre o Canadá (parlamentarista), EUA e México (presidencialistas), ou com uma feição majoritariamente parlamentarista, como na União Européia e o ASEAN. 
demais blocos econômicos existentes. Nos países formadores da União Européia, tem-se a enorme experiência parlamentarista, com a constante alternância no poder, voto de desconfiança e a possibilidade de eleições antecipadas que refletirão na estrutura do bloco. Nos países pertencentes ao MERCOSUL, isso não existe, o que poderia apresentar uma maior estabilidade ao sistema por um lado, e, por outro, uma menor participação popular.

Saber a resposta à questão formulada como título, isto é, se o presidencialismo é ou não um fator de integração no âmbito do MERCOSUL é discutir a própria feição desta integração.

Torna-se, portanto, necessário fazer-se uma análise do sistema presidencialista e do modelo adotado pelos Estados-Partes do MERCOSUL, posto ser indubitável o fato de que ações isoladas mudaram e mudam o alcance e a direção da integração repetidas vezes. 


\section{CAPÍTULO III}

\section{CONDIÇÕES HISTÓRICAS E SOCIAIS PARA O SURGIMENTO DO SISTEMA ${ }^{98}$}

O sistema representativo presidencialista foi idealizado ${ }^{99}$ pelos norteamericanos na Convenção de Filadélfia ${ }^{100}$ e consubstanciado na Constituição Federal de 17 de setembro de $1787^{101}$.

É, o presidencialismo ${ }^{102}$, uma versão republicana da monarquia limitada ou constitucional, existente na Inglaterra desde 1688, quando da chamada Revolução

Gloriosa que, dentre outras coisas, instaurou a separação de poderes ${ }^{103}$, abrindo o

98 Adaptação, com modificações, do texto WINTER, Luís Alexandre Carta. A crise do modelo presidencialista no âmbito do MERCOSUL. Curitiba: Juruá, 2002. p. 5-34.

99 Jorge Miranda aborda que "o presidencialismo surgiu com a Constituição dos Estados Unidos e só aí tem sido verdadeiramente aplicado e tem funcionado eficaz e pacificamente. Para lá da influência dos doutrinários, alguns fatores históricos explicam bem a sua instauração: a experiência colonial, com governadores nomeados pela Coroa britânica e assembléias eletivas; a tendência natural para conceber o Presidente à imagem do Rei da Inglaterra (no século XVIII ainda exercendo a 'prerrogativa'); a vontade dos pais da Constituição de evitarem tanto o despotismo de um homem só como os vícios das assembléias soberanas". (MIRANDA, Jorge. Manual de Direito Constitucional Preliminares o Estado e os Sistemas Constitucionais. 6. ed. Coimbra: Coimbra, 1997. p. 152, t. I)

100 Sobre a Convenção de Filadélfia ver: PADOVER, Saul K. A Constituição viva dos Estados Unidos. São Paulo: IBRASA, 1987 e COOLEY, Thomas M. Princípios Gerais de Direito Constitucional nos Estados Unidos da América. Campinas: Russell, 2002.

${ }^{101}$ Richard B. Morris discorre que a "Convenção Constitucional, convocada em Filadélfia, em 25 de maio de 1787, concluiu sua obra em menos de quatro meses. Na convenção foi examinado o plano 1, de Virgínia, proposto por Edmound Randolph, que foi além dos trabalhos da revisão dos Artigos da confederação e advogou um novo governo nacional com uma legislatura de duas câmaras representando proporcionalmente os estados". (MORRIS, Richard B. Documentos Básicos da História dos Estados Unidos. Rio de Janeiro: Fundo de Cultura, 1964. p. 65)

${ }^{102}$ Canotilho sustenta ter sido Walter Bagehot, em seu livro The English Constitution, de 1867, quem se referiu, pela primeira vez, à forma de governo dos Estados Unidos como "governo presidencial" (Presidential government) para contrapor à forma de governo inglesa por ele designado de "governo de gabinete". (CANOTILHO, J. J. Gomes. Direito Constitucional e Teoria da Constituição. 4. ed. Coimbra: Almedina, 2000. p. 569)

${ }^{103}$ Norberto Bobbio argúi que desde a obra Política, de Aristóteles, já se distinguia três tipos de poder. Na Política o era com base no critério de esfera em que é exercido, quais sejam, o poder do pai sobre os filhos, do senhor sobre os escravos, do governante sobre os governados. Boobio discorre que para Aristóteles os três tipos de poder também podem ser diferenciados com base no específico sujeito que se beneficia com o exercício do poder, ou seja, o poder paterno é exercido no interesse dos filhos, o senhoral ou despótico no interesse do senhor, o político no interesse de quem governa e de quem é governado. (BOBBIO, Norberto. Estado Governo Sociedade - para uma teoria geral da política. 4. ed. São Paulo: Paz e Terra, 1995. p. 78-79) 
caminho para as doutrinas de Locke L $^{104}$ e Montesquieu ${ }^{105 / 106}$.

Declarada a independência das treze antigas colônias inglesas, forma-se, em 1781, a "Confederação dos Estados Unidos da América do Norte"107, composta de países livres ${ }^{108}$.

Tal estrutura permaneceria até a Convenção de Filadélfia, na qual, por necessidades comuns no plano militar, econômico e social, dentre outros, fundir-se-ia, formando um só Estado, não obstante a grande autonomia dada para os agora treze Estados.

104 John Locke, filósofo inglês, nascido em Bristol, em 1632 e falecido na Holanda em 1704, em sua obra, Segundo Tratado sobre o Governo (publicada em 1690), partindo da análise do que seria o "estado da natureza", discute a origem, a organização e os fins da sociedade política e do governo, mostrando a interligação entre os poderes legislativo, executivo e federativo, tratando, ainda, da usurpação do poder, da tirania e da dissolução do governo. (LOCKE, John. Segundo Tratado sobre o Governo. 2. ed. São Paulo: Abril, 1983. Coleção Os Pensadores). Bobbio sustenta que a distinção do poder, para Aristóteles, era fundada sobre o interesse e, para Locke, é fundada sobre o princípio da legitimidade. (BOBBIO, N. Ob. cit., p. 79)

${ }^{105}$ Charles Louis de Secondat, Barão de Montesquieu, filósofo francês, nascido em 1689 e falecido em 1755; publicou Do Espírito das Leis (1748). No transcurso dessa obra, Montesquieu constrói a teoria da separação dos poderes. (MONTESQUIEU. Do Espírito das Leis. 3. ed. São Paulo: Abril, 1985. Coleção Os Pensadores). Bobbio sustenta que "a natureza de um governo deriva de sua estrutura, isto é, da constituição que regula de certo modo - diferente em cada forma - quem governa, e como. Mas as formas de governo podem ser caracterizadas também, de acordo com Montesquieu, pela paixão fundamental que induz os súditos a agir de conformidade com as leis estabelecidas, permitindo assim a durabilidade de todo ordenamento político". (BOOBIO, Norberto. A Teoria das Formas de Governo. 8. ed. Brasília: UnB, 1995, p. 132-33)

${ }^{106}$ Canotilho discorre que Jonh Locke, no que se refere à organização do poder político, segundo o princípio da separação dos poderes, aponta quatro poderes, quais sejam, o legislativo, o executivo, o federativo e o prerrogativo, que subsistiriam em um nível funcional. No nível institucional se teria o Parlamento, com a Câmara Baixa e Câmara dos Lords, e o Rei no parlamento e a Coroa, abarcando o Governo, a Administração e os Tribunais. Finalmente, no nível social, tem-se o povo, os nobres e a casa real. Já, para Montesquieu, a divisão funcional abrange o legislativo, executivo e o judiciário, diferenciando-se de Locke ao dar autonomia ao poder judiciário e ao incluir os poderes federativo e prerrogativo no âmbito do executivo. (CANOTILHO, J. J. Gomes. Ob. cit., p. 564-565)

${ }^{107}$ Assinado em 09.07.1777 e ratificado em 01.03.1781. Era composta por treze artigos.

$108 \mathrm{O}$ art. $2^{\circ}$ dispunha que "cada estado reterá sua soberania, liberdade e independência, e cada poder, jurisdição, e direitos, que não sejam delegados expressamente por esta confederação para os Estados Unidos, reunidos em Congresso". 
Estava criado o princípio da federação ${ }^{109} \mathrm{e}$, com a nova estruturação que se fez, o presidencialismo ${ }^{110}$.

sistema criado era, na realidade, uma adaptação da monarquia à forma republicana $^{111}$, com modificações, em razão de que os princípios monárquicos da vitaliciedade e hereditariedade foram substituídos pelos da temporariedade e eletividade ${ }^{112}$.

O que impactava aos americanos à época era a posição do rei da Inglaterra, Jorge III $^{113}$. Isto posto, natural se faz a observação de Ellis Stevens no sentido de que, por ser o soberano inglês autoritário e poderoso, "deixou uma profunda impressão na América, que acabou por fixar traços permanentes nas disposições constitucionais relativas ao executivo ${ }^{114}$ americano"115 $^{115}$ uma delas foi, inclusive, a

${ }^{109}$ Contribuiu decisivamente para o funcionamento do sistema Federalista, o trabalho de Alexander Hamilton, James Madison e John Jay, reunidos em forma de livro na primavera de 1788 , sob o título O federalista. (O Federalista. Campinas: Russell, 2003).

${ }^{110}$ O resultado final foi o contido no art. II, $\S 1^{\circ}$, primeira parte, da Constituição do EUA, que reza: "O Poder executivo será revestido pelo Presidente dos Estados Unidos da América. Ele conservará seu Cargo durante o período de quatro anos e, junto com o Vice-Presidente, escolhido para o mesmo período, será eleito, como segue."

${ }^{111}$ Dalmo de Abreu Dallari, em sua obra Elementos de Teoria Geral do Estado, sustenta que "os fundadores do Estado norte-americano tinham plena consciência de estarem criando uma nova forma de governo. Na medida das possibilidades aplicaram as idéias contidas na obra de Montesquieu, relativas à liberdade, à igualdade e à soberania popular. Além disso, atentaram para as necessidades práticas, procurando conciliar os conflitos de interesses e de tendências registrados entre os constituintes, criando um sistema de governo suficientemente forte e eficiente para cumprir suas tarefas e convenientemente contido para não degenerar num absolutismo". (DALLARI, Dalmo de Abreu. Elementos de Teoria Geral do Estado. 19. ed. São Paulo: Saraiva, 1995. p. 203)

${ }^{112}$ No dizer de Summer Maine, "embora temporário e eletivo, no exercício do mandato, o Presidente da República passou a refletir a majestade e onipotência de Jorge III, rei autoritário que exercia o absoluto e total controle sobre seus Ministros de Estado, chegando a dominar, inclusive, o próprio Parlamento". (Apud MALUF, Sahid. Teoria Geral do Estado. 11. ed. São Paulo: Sugestões Literárias, 1980. p. 253). As obras de Sir Henry Summer Maine estão disponíveis em: <http://www. dominiopublico.mec.gov.br/pesquisa>. Acesso em: 24 jan. 2008.

${ }^{113}$ Machado Paupério (Presidencialismo, Parlamentarismo e Governo Colegial. Rio de Janeiro: Revista Forense, 1956. p. 12) e Sahid Maluf (Teoria Geral do Estado. 11. ed. São Paulo: Sugestões Literárias, 1980. p. 254) discorrem que "o Presidente da República, modelado na Constituição de 1787, por seu excessivo poder, assemelhava-se a um rei eletivo e temporário, pois, com a soma imensa de poderes que ele enfeixa em suas mãos, a ele só faltam a hereditariedade e perpetuidade, a corte e os européis".

${ }^{114} \mathrm{O}$ art. $2^{\circ}$, § 2, da Constituição Norte Americana, dispõe, dentre outras coisas, que o Presidente é o Comandante em Chefe das forças armadas, tendo poder para conceder moratórias, perdão, 
forma de escolha do Chefe do Executivo ${ }^{116}$.

Por existirem vários sistemas presidencialistas ${ }^{117}$, tais como o norteamericano, o brasileiro, argentino, uruguaio, peruano, mexicano, dentre outros, cada um com suas peculiaridades, os autores de maneira geral tergiversam ao definir presidencialismo, optando por abordar diretamente as características do sistema presidencialista.

O dicionário Aurélio define o presidencialismo de modo simplista, como sendo "o regime político em que a chefia do governo cabe ao presidente da República, mantendo-se a independência e a harmonia dos três poderes"118.

O Vocabulário Jurídico de Plácido e Silva define-o de maneira incompleta, como "em oposição ao regime parlamentar, exprime a forma de governo em que, embora harmônicos, há independência de poderes, agindo cada um na esfera de suas atribuições. No regime presidencial, o chefe do governo é quem escolhe e

promover tratados (com o consentimento do senado), poderá ainda preencher todas as vagas ocorridas durante o recesso do Senado, poderá convocar ambas as casas, protelar resoluções até o tempo que julgar apropriado, receber Embaixadores, cuidar que as Leis sejam executadas fielmente, e comissionar todos os funcionários federais. MORRIS, Richard, ob. cit., p. 75-76.

115 MALUF, Sahid. Ob. cit., p. 253-254 e também STEVENS, Ellis C. Sources de la Constitution des Etats-Unis. Tradução de Louis Vossion. Paris: Guillaumin, 1897.

${ }^{116}$ Bruce Ackerman salienta que "Os Fundadores tinham plena consciência de que os norteamericanos desconfiavam do Poder Executivo após sua experiência com George III. Seu conhecimento em história antiga ressaltou o perigo que um presidente demagógico poderia causar, desestabilizando a República na tentativa de se tornar rei. Em vez de interpretar a luta pela Presidência como uma ocasião para mobilizar o apoio das massas para ideais programáticos, os Fundadores projetaram o sistema de escolha por diversas razões. [...]. Para seus criadores, o Colégio Eleitoral foi um hábil recurso para desatrelar a Presidência das vias populares. Ele visava a encorajar a escolha do homem que contasse com o passado mais distinto de prestações de serviço à República. A virtude republicana e não a demagogia populista, deveria ser a sua principal qualidade". (ACKERMAN, Bruce. Nós, o Povo Soberano - Fundamentos do Direito Constitucional. Belo Horizonte: Del Rey, 2006. p. 92-93)

117 Octavio Amorim Neto discorrendo sobre o continente americano, diz que "os regimes presidencialistas do continente, todavia, em muito se diferem. Observa-se uma grande variação na estrutura institucional adotada pelas nações, [...] e que - em interação com a inclinação ideológica do presidente, o sistema partidário e as condições econômicas - se reflete em uma diversidade de padrões de governança, que, por sua vez, podem ser associados ao desempenho político e econômico dos países das Américas". (AMORIM NETO, Octavio. Presidencialismo e Governabilidade nas Américas. Rio de Janeiro: FGV, 2006. p. 17-18)

118 BUARQUE DE HOLANDA. Aurélio Ferreira. Novo dicionário da Língua Portuguesa. 13 impressão. Rio de Janeiro: Nova Fronteira, p. 1.134. 
nomeia seus ministros, sem qualquer intervenção do legislativo"119.

Deixando-se ao largo o conceito, optando-se por uma caracterização, pode-

se afirmar que o Presidencialismo se apresenta ${ }^{120}$, basicamente, pelo fato de uma mesma pessoa, por um período transitório, por eleição direta ou não, ser chefe de

Estado e de Governo, e, basicamente, nesta condição, o Presidente é chefe de toda

a administração pública, é responsável pela condução da política externa (nesta

${ }^{119}$ SILVA, De Plácido e. Vocabulário Jurídico. São Paulo: Forense, 1963. p. 1.324. v. IV.

${ }^{120}$ Inúmeros são os autores que traçam as características do presidencialismo. J. J. Gomes Canotilho (ob. cit. p. 569-571), por exemplo, escolhendo como arquétipo da forma de governo presidencial o dos Estados Unidos, sustenta que seus traços fundamentais podem sintetizar-se da seguinte forma: a) Separação de poderes - os poderes legislativo, executivo e judiciário são constitucionalmente consagrados como três poderes independentes... O poder executivo é atribuído a "um Presidente dos Estados Unidos" eleito por um colégio de eleitores designados pelas legislaturas dos Estados (e não pelo Congresso Federal) para um mandato de quatro anos. b) Legitimação - o Chefe do Estado - Presidente da República - é dotado de legitimidade democrática "quase direta", pois ele é eleito por um colégio formado por grandes eleitores em número igual ao de senadores e representantes. Embora haja, em geral, coincidência entre os votos populares (daí o afirmar-se que o Presidente tem legitimidade democrática direta) e os votos dos "grandes eleitores", existe a possibilidade de ser eleito presidente um candidato que tem a maioria de "mandatos eleitorais" mas sem maioria de "votos populares". c) Governo - o Presidente da República é, simultaneamente, "chefe do estado e chefe do governo", e daí a ausência de um gabinete ministerial no verdadeiro sentido e a existência de simples secretários de Estado, subordinados ao Presidente. É o monopolismo do executivo. d) Poder Judiciário - assume grande relevância através da Suprema Corte e da fiscalização da constitucionalidade das leis. É um importante contrapeso para limitar a força do executivo e do legislativo. e) Controles - não existem controles primários entre o Presidente da República e o Congresso: o Presidente não tem poderes de dissolução das câmaras e nenhuma destas ou ambas tem a possibilidade de aprovar moções de censura contra o Presidente. O governo é "irresponsável" e o parlamento "indissolúvel". Daí o afirmar-se que os poderes são "poderes separados". [...] argúi que, apesar de não existirem controles primários, há alguns elementos de contrapeso, posto o Presidente poder ser destituído através do processo de impeachment e o Senado ter que dar seu assentimento à nomeação dos secretários de Estado e altos funcionários do executivo, por sua vez, pode o Presidente usar do direito de veto aos atos do legislativo, que só poderão ser derrubados por $2 / 3$ dos votos de cada uma das câmaras. Luis Agesta Sanches também retrata as características do presidencialismo norte-americano de modo similar (SANCHES, Luis Agesta. Curso de Derecho Constitucional Comparado. 7. ed. Madrid: Universidad Complutense de Madrid, 1980. p. 198-202). Já, outros. como Manoel Gonçalves Ferreira Filho, tentam retratar o sistema presidencialista como um todo, afirmando que as características fundamentais do presidencialismo em seu sentido amplo, no plano jurídico, serem "as seguintes: a) É um regime de separação de poderes, atribuídas a órgãos independentes que as exercem com exclusividade relativa. b) A chefia do Estado e do Governo são conferidas a um órgão unipessoal: a Presidência da República. c) A independência recíproca do Executivo e do Legislativo é rigorosamente assegurada. Em outras palavras, a reunião do Legislativo não pressupõe, necessariamente, a convocação do chefe de Estado que, por sua vez, não pode por fim ao mandato dos parlamentares, dissolvendo a Câmara e convocando novas eleições, tampouco pode a Câmara destituir o Presidente - mesmo quando não contar com sua confiança -, o que somente ocorrerá no evento de um crime, como sanção". (GONÇALVES FERREIRA FILHO, Manoel. Curso de Direito Constitucional. 9. ed. São Paulo: Saraiva, 1980. p. 120)Semelhante é a posição de AZAMBUJA, Darcy. Teoria Geral do Estado. Porto Alegre: Globo, 1977. p. 296-297. 
condição encarna a irresponsabilidade política, ele representa a nação no exterior),

é chefe das Forças Armadas, é responsável pela condução da política de governo,

tem autonomia na escolha de seus ministros, e, em relação ao Poder Legislativo, tem direito à iniciativa na elaboração das leis (ou seja, está investido de importantes funções legislativas ${ }^{121}$ ), além do direito de veto ${ }^{122}$ (que pode, eventualmente, ser derrubado). Em relação ao Poder Judiciário, escolhe os juízes das Cortes Superiores (mesmo que a escolha tenha que ser aprovada pelo Poder Legislativo), embora exista, conceitualmente, uma separação de poderes, estes seriam independentes e autônomos ${ }^{123}$. Esta independência era inicialmente absoluta, no sentido de que não havia formalmente contatos entre os poderes. Mais tarde, nos

${ }^{121}$ Que compreenderiam, segundo MALUF, Sahid, p. 258, em: a) O direito de iniciativa de qualquer projeto de lei. b) O direito exclusivo de iniciativa de determinados projetos de lei, de ordens administrativas, econômico financeira, militar etc. c) Competência para praticar os conclusivos e integrativos da lei, promulgação, sanção e publicação. d) O direito de veto. Quanto a este, o chefe do poder executivo, em regra, pode vetar vários artigos ou apenas um artigo, um parágrafo ou uma só palavra e, a este veto só poderá ser rejeitado por dois terços das duas câmaras congressuais reunidas, o que não será nada fácil vez que, a se considerar o fato de que as maiorias parlamentares "situacionistas" são freqüentemente submissas e controladas por um "líder do governo", segue-se que geralmente as funções legislativas exercidas pelo chefe do poder executivo superam a própria competência específica do Congresso. Note-se, ainda, que o Presidente da República pode sobrepor-se ao poder judiciário, tornando insubsistentes os seus julgados, pela iniciativa da lei de anistia e pela prerrogativa de conceder a graça ou indulto, bem como a comutação da pena. (MALUF, Sahid. Ob. cit., p. 258). Especificamente em relação ao Brasil, José Afonso da Silva salienta que dentre as exceções ao princípio da divisão de poderes tem-se, hoje, a possibilidade de adoção, pelo Presidente da República, de medidas provisórias, com força de lei (art. 62), e na autorização de delegação de atribuições legislativas ao Presidente da República (art. 68) (SILVA, José Afonso da, ob. cit., p. 115-116). Clèmerson Merlin Cléve coloca uma questão interessante. Separação de poderes ou separação de funções? Ele salienta que "na sociedade de massas não há como manter a distinção entre legislação (função legislativa) e administração (função executiva). O governo compreende ações legislativas e administrativas. A legislação e a execução das leis "não são funções separadas ou separáveis, mas sim diferentes técnicas do political leadership. A liderança política, a atividade de governo conforma a vontade popular, impondo a sua política por meio da aprovação parlamentar das leis ou de sua execução. Não há separação de poderes evidente entre o Executivo e o Legislativo, uma vez que o governo lidera politicamente os dois poderes". (CLÉVE, Clèmerson Merlin. Atividade Legislativa do Poder Executivo. 2. ed. São Paulo: RT, 2000. p. 29 e 33)

122 Segundo Dalmo de Abreu Dallari (ob. cit. p. 204-206), "para evitar-se a possibilidade de uma ditadura do legislativo". O que, ressalte-se já ocorreu, como, por exemplo, no século XIX, houve um confronto, no Chile entre o executivo e o legislativo. O Presidente Balmaceda foi derrotado e implantou-se uma ditadura do legislativo.

${ }^{123}$ Jorge Miranda (ob. cit., p. 153) ressalta ainda concernente à separação dos poderes e ao sistema presidencial, argüindo "que a organização política da União (tal como a dos Estados) dir-se-ia diretamente inspirada em Montesquieu: três poderes - legislativo, executivo, judicial - e cada poder não só produzindo os atos inerentes à sua função mas também interferindo em atos doutros 
EUA e posteriormente em outros países que adotaram o sistema presidencialista, atenuaram essa separação, com a criação das Comissões do Congresso ${ }^{124}$.

Nos EUA, em particular, o sistema presidencialista evoluiu ${ }^{125}$ de modo substancialmente diferente do de outros países que adotaram o sistema, a ponto de defender-se ${ }^{126}$ que, nos Estados Unidos, o presidencialismo tenha adquirido a feição de um sistema de "supremacia congressual", dada a influência do sistema de freios e contrapesos que nele se verifica.

Nos EUA, o Senado, dos dois ramos do Congresso, passou a ser o mais poderoso elemento político daquele país, pois, tal como observava o próprio Presidente Woodrow Wilson ${ }^{127}$, sem as autorizações expressas do Senado, o poder do Presidente da República reduz-se a muito pouco ${ }^{128}$.

órgãos, contribuindo para a produção dos seus efeitos ou impedindo que eles se dêem. É aquilo a que se tem chamado um mecanismo de checks and balances, de freios e contrapesos".

${ }^{124}$ Samuel E. FINER ressalta o poder das Comissões do Congresso, que podem cortar e modificar verbas e atuar diretamente no andamento dos projetos de lei. O executivo não pode intimidar as Comissões do Congresso e nem sobrepor-se a elas. O que pode é usar o poder de veto e vetar os projetos de lei de interesse de grupos de parlamentares, já que a maioria de dois terços necessários para derrubar o veto não é fácil de obter. Trata-se de uma situação de barganha. (FINER, Samuel E. Governo Comparado. Brasília: UnB, 1981. p. 235-236)

${ }^{125}$ Relativamente às variantes do sistema presidencial em sua evolução, Sahid Maluf (ob. cit., p. 265266) destaca quatro variantes do sistema presidencial: "a) Presidencialismo puro, com a divisão radical dos poderes. Os ministros não podem comparecer ao Congresso, sequer para obter ou prestar informações, enquanto que os membros do congresso não podem aceitar funções ministeriais, sem a perda do mandato. Ex.: a Constituição Republicana de 1891. b) Presidencialismo atenuado, que permite o compadecimento dos Ministros perante as câmaras legislativas. Os ministros assistem às sessões do congresso, onde funcionam como verdadeiras antenas do poder executivo, captado o pensamento das maiorias em relação aos problemas de maior relevo, ao mesmo tempo em que levam o pensamento do executivo e solicitam providências. Ex.: a Constituição brasileira de 1946. c) Presidencialismo temperado, que admite a fiscalização efetiva do poder legislativo sobre o executivo, inclusive o voto de censura, embora sem a conseqüência de uma demissão forçada. Ex.: Venezuela, até 1999 (antes da reforma proposta por Hugo Chaves). d) Presidencialismo eclético, com Ministros livremente nomeados pelo Presidente da República, mas dependentes da confiança do congresso. Ex.: EUA".

${ }^{126}$ PAUPÉRIO, Machado. Ob. cit., p. 20.

${ }^{127}$ Apud PAUPÉRIO, Machado. Ob. cit., p. 20.

${ }^{128}$ Jeffrey Tulis salienta que "Wilson, em seus escritos, atacou conscientemente o The Federalist (uma série de publicações, escritas em sua maior parte pelo Presidente Madison); na presidência ele tentou agir de acordo com os princípios de sua reinterpretação do sistema político norteamericano. A partir daí, os presidentes continuaram seguindo seu exemplo e os estudiosos da presidência tendem a repetir seus argumentos. Assim como The Federalist representa a mais profunda e coerente articulação dos conhecimentos acerca da presidência comumente conservados do século XIX, Wilson fornece a mais abrangente teoria em defesa das motivações e 
O Senado norte-americano exerce forte influência nos negócios estrangeiros, notadamente em matéria de tratados internacionais, que restam invalidados se não contarem com sua ratificação ${ }^{129}$.

O Senado participa, ainda, da nomeação dos altos funcionários do Governo, inclusive dos ministros da Suprema Corte, fiscaliza a ação dos vários departamentos administrativos, influencia e controla a legislação em geral e a despesa pública em particular; além disso, as nomeações dos secretários de Estado também dependem de sua anuência. Por todas estas razões, é uma grande vitória para o Executivo norte-americano contar com a maioria, no Senado.

A Câmara prepondera, tal como o Senado, mas através das chamadas Comissões Permanentes ${ }^{130}$.

A força dessas Comissões está nos projetos de lei, que somente logram aprovação se apresentados por seus membros ou se a eles interessarem. A Suprema Corte também não escapa ao controle do Congresso, vez que o Legislativo pode aumentar o número de magistrados valendo-se de critérios próprios ou, até

dos procedimentos contemporâneos". (TULIS, Jeffrey. As duas Presidências Constitucionais. In: MICHEL, Nelson (Org.). A Presidência e o Sistema Político - Política Norte-Americana Hoje. São Paulo: Alfa-ômega, 1985. p. 80-81)

${ }^{129}$ Apesar disto, ou exatamente em razão deste fato, surge nos EUA os chamados acordos executivos ou acordos em forma simplificada. MELLO, Celso de Albuquerque, Curso de Direito Internacional Público. 13. ed. Rio de Janeiro: Renovar, 2001. v. I, p. 222-223, discorre que "a intervenção do Poder Legislativo se desenvolveu justamente com a democracia. Todavia, nos últimos decênios se têm propagado práticas no sentido de se fugir ao seu controle. O Congresso normalmente é lento, não se adaptando assim à vida internacional, extremamente rápida. A principal prática neste sentido são os denominados acordos em forma simplificada, que se desenvolveram, acima de tudo, nos EUA, com o desejo de fugir ao controle do Senado. Eles somente se distinguem dos tratados em seu aspecto formal, isto é, não estão sujeitos à aprovação pelo Legislativo, daí a sua denominação de 'acordos em forma simplificada'". No mesmo sentido, Hildebrando Accioly argúi "poder-se admitir razoavelmente que, quando o compromisso verse sobre matéria executiva, não há razão para que ele seja submetido ao poder legislativo, e isto tem sido reconhecido, desde muito, nos EUA, onde a prática dos acordos executivos já recebeu consagração da própria Suprema Corte, apesar do que dispõe a Constituição americana em relação a tratados". (ACCIOLY, Hildebrando. Manual de Direito Internacional Público. 12. ed. São Paulo: Saraiva, 1996. p. 26)

${ }^{130}$ Estas Comissões são correspondentes às Comissões Parlamentares de Inquérito, uma instituição originária do sistema parlamentarista. 
mesmo, alterar-Ihe a competência.

No sistema presidencialista, por haver a independência dos poderes, nem o

Presidente da República é politicamente responsável diante do Poder Legislativo,

nem este é suscetível de dissolução pelo Presidente. Este fator pode gerar, poten-

cialmente, grandes tensões, já que ambos possuem legitimidade popular.

A questão fica mais complexa se, no país que adote o sistema

presidencialista, adotar, igualmente, o pluripartidarismo. Este fator pode

eventualmente proporcionar que o Presidente, seja eleito por um partido, e este

partido seja amplamente minoritário no Parlamento ${ }^{131}$. Em outras palavras, o

Presidente foi eleito com base, também, em um programa de governo, mas, para

${ }^{131}$ Quem analisa muito bem essas questões é TAVARES, José Antônio Giusti O sistema político Brasileiro. In: TAVARES, José Antônio Giusti; ROJO, Raúl Enrique (Orgs.). Instituições Políticas Comparadas dos Países do MERCosUL. Rio de Janeiro: Fundação Getúlio Vargas, 1998. p. 251. Tavares sustenta que: "relativamente ao sistema presidencial que: dualista, supõe o sistema presidencial de governo, no qual dois dentre os três poderes constitucionais, o Legislativo e o Executivo, são escolhidos por processos eleitorais senão diferentes pelo menos independentes entre si, com mandatos para exercerem as suas funções por prazo fixo, e no qual, de um lado, o detentor do poder executivo, o presidente, não é politicamente responsável diante do Poder Legislativo e, de outro, este último, bicameral, e neste caso designado Congresso, ou unicameral, não é suscetível de dissolução pelo presidente. Do dualismo genético decorre o dualismo estrutural e funcional que essencialmente caracteriza o presidencialismo, a irresponsabilidade e a intransitividade recíprocas entre aqueles dois poderes constitucionais, bem como as tensões e os dilemas constitucionais inerentes à convivência, nele, entre duas pretensões concorrentes e conflitivas de legitimidade". E, às p. 256-257 complementa: "existem dois tipos de presidencialismo: o majoritário com bipartidarismo congressual e o presidencialismo proporcionalista com pluripartidarismo congressual". No sistema de presidencialismo majoritário com bipartidarismo congressual, Giusti Tavares sustenta que "quando a Presidência e a maioria congressual pertencem a partidos diferentes, a existência de um único partido parlamentar de oposição, coeso, disciplinado, sólido e centralizado, isto é, de uma única e homogênea maioria parlamentar de oposição, reforça a separação constitucional de poderes e limita significativamente o poder presidencial. [...] O bipartidarismo sólido e disciplinado consensualiza, legitima e fortalece, mas ao mesmo tempo delimita a autoridade do presidente, associando-o, ainda que como líder, a um dos dois partidos". No sistema de presidencialismo proporcionalista com pluralidade congressual, Giusti Tavares argumenta que neste sistema, "o presidente é eleito por alguma variedade da regra de pluralidade ou de maioria, empregando-se alguma regra proporcional para distribuir, entre os partidos, e segundo o volume relativo de votos de cada um, as cadeiras legislativas. [...] No presidencialismo, o multipartidarismo congressual tende a conduzir à fragmentação e à instabilidade das coalizões no Congresso, nele instalando a paralisia de decisão e de poder, inviabilizando a constituição de uma maioria parlamentar estável de sustentação do governo e aprofundando o dualismo, inerente ao sistema presidencial, entre o Poder Legislativo e o presidente". 
implementar esse programa, necessita de uma maioria no Parlamento ${ }^{132}$. A maioria deste pode lhe ser contrária, criando um impasse, uma paralisia geradora de enormes tensões ${ }^{133}$.

Nos EUA, essa questão não ocorre, já que materialmente no Parlamento há a supremacia de dois partidos: o do Presidente e o da oposição. As negociações ficam dessa forma mais facilitadas, já que haverá um número partidariamente menor de interlocutores (o partido da situação e o partido da oposição).

Nas demais regiões do Globo onde o sistema presidencialista foi implantado, este conserva pouca semelhança com o sistema norte-americano.

Nos países africanos ${ }^{134}$ que o adotaram, carregam, em cada um deles, algumas peculiaridades regionais. À exceção do Egito moderno, que nasce como uma monarquia, derrubada por um golpe militar liderado pelo Coronel Gamal Abdel Nasser, em 1952, todos eles foram de colônias para ditaduras ${ }^{135}$ inicialmente hostis, em regra geral, ao Ocidente ${ }^{136}$.

${ }^{132}$ Para melhor ilustrar a questão, quando em Fernando Collor de Mello, foi empossado, em 1990, eleito diretamente, seu partido tinha apenas 5\% das cadeiras da Câmara dos Deputados. Em 1995, quando Fernando Henrique Cardoso assumiu, seu partido detinha $12 \%$ das cadeiras da Câmara. Ver AMORIM NETO, Octávio. Ob. cit., p. 18.

${ }^{133}$ Diferente do sistema parlamentarista. Manoel Gonçalves Ferreira Filho (ob. cit. p. 127) expõem que, juridicamente, o parlamentarismo se caracteriza pelos seguintes traços: "a) É um regime de divisão de poderes, na medida em que adota a distinção clássica das funções do Estado e sua atribuição a órgãos diversos. b) Os poderes legislativo e executivo são interdependentes pois o governo, de fato, para manter-se no poder, depende do apoio da maioria parlamentar, que pode a qualquer instante, seja votando moção de desconfiança, seja rejeitando questão de confiança, apeá-lo do mesmo. Por outro lado, o legislativo, ou pelo menos a sua câmara baixa pode ser dissolvido pelo governo, convocando-se nova eleição. c) $O$ executivo parlamentarista possui estrutura dualista. O rei ou o Presidente da República, é o chefe de Estado, com funções de representação, de cerimonial e de conselho, enquanto o governo é exercido por um órgão coletivo, o conselho de ministros ou gabinete, presididos por um primeiro ministro, como chefe de governo".

${ }^{134}$ Angola, Quênia, Tanzânia, Egito, Togo (embora ditadura militar), Costa do Marfim (embora ditadura militar), dentre outros.

${ }^{135}$ Celso D. de Albuquerque Mello (ob. cit., p. 1.535) salienta que "na África, em julho de 1963, havia dois países governados por militares; em julho de 1968, havia 10; em julho de 1973, havia 18 e em julho de 1978, havia 22".

${ }^{136}$ Arnold Toynbee discorre que "entre 1881 e 1904, todos os países africanos, à exceção de dois (Libéria e Abissínia) ainda imunes ao domínio europeu ocidental em 1871, foram trazidos para o 
Com o desaparecimento da União Soviética, os países africanos

abrandaram, de modo geral, seus regimes passando a adotar, um incipiente e instável $^{137}$ regime presidencialista, melhor adaptável a países sem tradição democrática.

Já nos Países da América Latina, historicamente, via de regra, o presidencialismo é um sistema de incondicionada supremacia do presidente. Os povos latino-americanos herdaram da Península Ibérica a propensão a governos fortes, com poder centralizado ${ }^{138}$ gerando conseqüências na política, já que não havia uma real participação popular na escolha dos governantes, existindo sim, verdadeiros currais eleitorais. Outra questão que os governos altamente centralizados da América Latina provocaram, foi um evidente cerceamento da liberdade econômica ${ }^{139}$, principalmente nos meados do século $\mathrm{XIX}^{140}$ aos meados do

controle direto ou indireto da Inglaterra, França, Alemanha, Bélgica ou Portugal". (TOYNBEE, Arnold. A Humanidade e a Mãe-Terra, Uma história narrativa do Mundo. 2. ed. Rio de Janeiro: Guanabara, 1987. p. 703)

137 Jorge Miranda (ob. cit., p. 219) salienta que "as notas mais salientes dos regimes nacionalistas revolucionários não marxistas-leninistas na África eram: a) a adoção como ideologia oficial de um socialismo de índole não marxista (socialismo árabe ou africano); b) o partido único, agora no sentido de movimento de libertação (ou de movimento de unificação social e política), e não no sentido de partido ideológico de classe que conquista o poder; c) a criação de uma administração fortemente centralizada; d) o empenho prioritário no desenvolvimento econômico, com sistema planificado".

${ }^{138}$ E essa tradição de um governo forte, com poder centralizado, só vai mudar na Espanha, verdadeiramente, a partir da queda do Franquismo e o ingresso desta na CEE (hoje UE). Quanto a Portugal, foi necessária a Revolução dos Cravos, e, igualmente, o ingresso deste na CEE para modernizar o Estado.

${ }^{139}$ Celso Furtado chama a atenção dos desequilíbrios e pressões inflacionárias básicas no âmbito da América Latina são: "a) inelasticidade da oferta de produtos agrícolas, isto em razão, basicamente 'em face do rápido crescimento da população empregada nas zonas urbanas, somente uma agricultura de produtividade crescente poderia fazer face à expansão da demanda'; b) inadequação da infra-estrutura, vez que 'tanto no que respeitam à agricultura, cuja expansão cobre novas áreas como no que concerne à indústria, que se abastece parcialmente de matériasprimas procedentes do interior, e necessita fazer com que seus produtos alcancem as distintas áreas do país, colocam-se sérios problemas de inadequação da infra-estrutura existente'; c) inadequação do fator humano disponível em curto prazo, já que existe 'abundante oferta de mão de obra, inexiste força de trabalho adequada às atividades industriais... há inexistência de tradição empresarial'; d) inadequação das estruturas fiscais, 'as receitas fiscais dependiam essencialmente do comércio exterior, particularmente das importações. Ao reduzir-se esta fonte fiscal, tentou-se uma conversão para o imposto de consumo, de elevado custo de arrecadação'; e) aumento dos encargos financeiros já que 'com os investimentos se realizando em condições de pressão sobre a balança de pagamentos, ou mesmo de declínio na capacidade para importar, os preços dos 
século $X X$, além da histórica alegação do não atingimento jurídico-constitucional que

os povos mais evoluídos política e economicamente ${ }^{141}$ possuem.

equipamentos tenderam a elevar-se em termos relativos'”. (FURTADO, Celso. A Economia Latino Americana. 2. ed. São Paulo: Nacional, 1978. p. 138-141)

140 LUXEMBURG, Rosa. A acumulação do capital. 2. ed. São Paulo: Nova Cultural, faz uma interessante análise do capitalismo financeiro que acometia as nações européias ocidentais, particularmente a Inglaterra do século XIX e início do século XX e que cabe, perfeitamente, como uma interessante e surpreendentemente atual análise da questão. Às fls. 288, argumenta que "no período imperialista, os empréstimos externos desempenham papel extraordinário como meio de emancipação dos novos Estados capitalistas. O que existe de contraditório na fase imperialista se revela claramente nas oposições características do moderno sistema de empréstimos externos. Eles são imprescindíveis para a emancipação das nações capitalistas recém-formadas e, ao mesmo tempo, constituem para as velhas nações capitalistas o meio mais seguro de tutelar os novos Estados, de exercer controle sobre suas finanças e pressão sobre sua política externa, alfandegária e comercial. Os empréstimos são um meio extraordinário para abrir novas áreas de investimento para o capital acumulado dos países antigos e para criar-lhes, ao mesmo tempo, novos concorrentes; são o meio de ampliar, no geral, o raio de ação do capital e de reduzi-lo concomitantemente". E, às p. 292 lembra "que o objeto da produção capitalista não é, no entanto, o consumo dos produtos, mas a mais-valia, a acumulação". Salientando, "o capital ocioso não tivera nenhuma possibilidade de acumulação no país de origem, já que lá não havia nenhuma necessidade de produtos excedentes. No exterior, contudo, onde ainda não havia produção capitalista desenvolvida, surge uma nova demanda em capadas não-capitalistas ou ela se cria de forma violenta. E é exatamente isso, ou seja, a transferência do 'usufruto' dos produtos para outros, que é decisivo para o capital. Isso porque o consumo das classes diretamente interessadas (capitalistas e operários) é totalmente estranho aos objetivos da acumulação. $O$ 'usufruto' dos produtos, contudo, precisa ser realizado e pago pelos novos consumidores. Para isso esses consumidores necessitam de meios monetários. Esses meios são fornecidos, em parte, pela troca mercantil que então se estabelece. ... O mais importante é que o capital acumulado do país mais velho encontre novamente outras possibilidades de produzir e realizar sua mais-valia, ou seja, que possa continuar com sua acumulação. Os países novos compreendem grandes territórios sujeitos à economia natural, que se transforma em economia mercantil; se já existe uma economia mercantil esta acaba substituída pelo capital". E, conclui, p. 308-309, que "a acumulação de capital como um todo, como processo histórico concreto apresenta, pois, dois aspectos distintos. Um deles desenvolve-se nos centros produtores da mais-valia - nas fábricas, nas minas, nas propriedades agrícolas - e no mercado. Vista sob esse ângulo, a acumulação é um processo puramente econômico - cuja fase mais importante se realiza entre os capitalistas e os trabalhadores assalariados e cujas duas fases (no espaço fabril e no mercado) desenvolvem-se exclusivamente dentro dos limites estabelecidos pela troca de mercadorias e pela troca de equivalentes... outro aspecto da acumulação de capital é o que se verifica entre o capital e as formas de produção não-capitalistas. Seu palco é o cenário mundial. Como método da política colonial reinam o sistema de empréstimos internacionais, a política das esferas de influência e as guerras". (LUXEMBURG, Rosa. A acumulação do capital. 2. ed. São Paulo: Nova Cultural, 1985)

${ }^{141}$ Maria da Conceição Tavares, em artigo intitulado "Auge e declínio do processo de substituição de importações no Brasil" publicado na obra Cinqüenta anos de pensamento na CEPAL, organizada por Ricardo Bielschowsky, às fls. 220, ao fazer a avaliação do significado do papel do setor externo nas economias periféricas sustenta que "na América Latina não só as exportações eram praticamente a única componente autônoma do crescimento da renda, como também o setor exportador representava o centro dinâmico de toda a economia" e, mais adiante, "o grau de difusão da atividade exportadora sobre o espaço econômico de cada país dependia da natureza do processo produtivo desses bens primários e do seu maior ou menor efeito multiplicador e distribuidor de renda [...]". E, prosseguindo, "de modo geral, o desenvolvimento do setor exportador deu lugar a um processo de urbanização mais ou menos intenso ao longo do qual se iam estabelecendo as chamadas indústrias de bens de consumo interno, tais como as de tecido, calçado, vestuário, móveis etc. Estas, como se sabe, são indústrias tradicionais, de baixo nível de produtividade, presentes em quase toda a América Latina, que surgiram no bojo do próprio modelo exportador". O que interessa, segundo Maria da Conceição Tavares, p. 221, "é o fato de que essa 
Falta à América Latina, na visão do Prof. Machado Paupério ${ }^{142}$, "a estabilidade jurídica dos povos amadurecidos e o esclarecimento da opinião pública". Não foi sem razão que Bolívar, em seu testamento, concluiu ser a América do Sul ingovernável ${ }^{143}$.

O presidencialismo possibilitou fatos que instituíram um clima favorável ao aparecimento de um poder caudilhesco ${ }^{144}$, na América Latina. No presidente se encarna, como afirmou Rui Barbosa ${ }^{145}$, "o poder dos poderes, o grande eleitor, o grande nomeador, o grande contratador, o poder da bolsa, o poder dos negócios, o poder da força"146.

reduzida atividade industrial, juntamente com o setor agrícola de subsistência, era insuficiente para dar à atividade interna um dinamismo próprio. Assim, o crescimento econômico ficava basicamente atrelado ao comportamento da demanda externa por produtos primários, dado o caráter eminentemente dependente e reflexo de nossas economias". (TAVARES, Maria da Conceição. Auge e declínio do processo de substituição de importações no Brasil In: BIELSCHOWSKY, Ricardo (Org.). Cinqüenta anos de pensamento na CEPAL. Rio de Janeiro: Record, 2000. p. 220-221)

142 PAUPÉRIO, Machado. Ob. cit., p. 35.

${ }^{143}$ Amado Luiz Cervo (ob. cit., p. 111) ressalta, contudo, a admiração de Bolívar pelas instituições e ordem existentes no Império do Brasil.

144 Octávio lanni discorre que "na forma latino-americana, a oligarquia combina constituições de inspiração liberal (divisões dos três poderes, eleições etc.) com as práticas e valores de tipo patrimonial polarizados em torno do cacique, patrón, gamonal, coronel ou caudilho. O poder é exercido por um sistema de 'caciquismo' no qual o ápice da pirâmide é ocupado pelo 'grande cacique' nacional. Nessa estrutura de poder, os funcionários, a burocracia pública federal, estadual e municipal, são recrutados entre os membros do 'partido' do governo, isto é, entre aqueles que são solidários política ou economicamente com os governantes". Os caudilhos eram grandes proprietários de terras que possuíam liderança política regional, exerciam o governo das províncias e contavam com apoio popular. (IANNI, Octávio. A Formação do Estado Populista na América Latina. 2. ed. São Paulo: Ática, 1989. p. 48). Alain Rouquié ressalta que "o caudilhismo nasce da decomposição do Estado após a queda das autoridades coloniais nas nações oriundas do antigo Império espanhol. São 'senhores da guerra', que nas condições confusas da independência, talham para si mesmos, à ponta de espada, um feudo. O caudilho é menos um homem carismático do que alguém que sebe criar redes de lealdade". (ROUQUIÉ, Alain. O Extremo-Ocidente. Uma Introdução à América Latina. São Paulo: Edusp, 1991. p. 218)

${ }^{145}$ Apud PAUPÉRIO, Machado. Ob. cit., p. 34.

${ }^{146}$ Alain Rouquié ressalta que "com exceção de Cuba, todos os países da América Latina adotaram instituições representativas e invocam a democracia pluralista. Ora, as descontinuidades políticas ou, ao contrário, o continuísmo ditatorial e diversas formas de autoritarismo, especialmente militar, parecem ter encontrado nesse continente uma terra de predileção". (ROUQUIÉ, Alain. O ExtremoOcidente. Uma Introdução à América Latina. São Paulo: Edusp, 1991. p. 96) 
Lolme $^{147}$ afirmava tudo poderem os presidentes latino americanos, menos transformar o homem em mulher.

Plaza $^{148}$, ex-presidente do Equador, proclamava que em relação ao modelo presidencialista adotado na América Latina "o sistema leva o presidente a ser ditador; seria preciso ter a alma de um Catão ${ }^{149}$ para resistir".

Via de regra, passaram, os presidentes ${ }^{150}$ dos Estados latino-americanos, a gozar da prerrogativa especial de decretar o estado de sítio e de suspender, conseqüentemente, as garantias constitucionais ${ }^{151}$.

MacDonald 152 afirmou que "a América Latina está em estado de permanente revolução, o povo aplaude qualquer aventureiro que assuma o poder. Os homens no poder são os menos qualificados e o povo, corrompido e incurável. O Governo será, assim, apanágio dos piores e o político é o mais desclassificado dos cidadãos...".

Howard Wiarda ${ }^{153}$ considera que, em raras exceções, a América Latina é "irrevolucionária" e que "a esperada revolução social de proporções hemisféricas

147 PAUPÉRIO, Machado. Ob. cit., p. 34.

${ }^{148}$ Idem, p. 34.

${ }^{149}$ Político da República romana, conhecido pela austeridade de seus princípios. Foi um dos maiores censores que Roma já teve.

${ }^{150}$ Celso Albuquerque Mello (ob. cit., p. 1.535) discorre que entre 1930 a 1965 houve na América Latina, 101 golpes militares de Estado com êxito. "Em Honduras houve 115 mudanças no Executivo em 125 anos. De 1945 a 1964 houve 54 quedas de governo na América Latina. Nos três anos seguintes à crise de 1929, isto é, em 1930,1931 e 1932, dezessete governos foram derrubados pela força em 12 países latino-americanos. Entre 1930 e 1957 o cargo de presidente na América Latina foi ocupado por 56 militares por pelo menos um ano".

${ }^{151}$ Bertrand Russell, sobre a domesticação do Poder, conta que "ao passar próximo ao Monte Tai, Confúcio encontrou uma mulher que chorava amargamente junto a um túmulo. O Mestre apressou o passo em direção a ela, e mandou Tzeu-lu falar com ela. O teu pranto, disse ele, é de quem sofreu amargura após amargura. Ela respondeu: É verdade. Certa vez o pai de meu marido foi morto aqui por um tigre. Depois meu marido, e agora foi meu filho que morreu do mesmo modo. $\mathrm{O}$ Mestre então perguntou-lhe: Por que não abandonas este lugar? E ela respondeu: é que não há governo opressor aqui. Disse então o Mestre: Lembrem-se disso, meus filhos: um governo opressor é mais terrível que tigres". (RUSSELL, Bertrand. O Poder. Rio de Janeiro: Zahar, 1979. p. 170)

${ }^{152}$ Apud PAUPÉRIO, Machado. Ob. cit., p. 38.

${ }^{153}$ Apud MELLO, Celso Albuquerque. Ob. cit., p. 1.535. 
não ocorreu e provavelmente não sobrevirá".

Apesar da triste história que a América Latina possui quanto a seus aspectos sócio-econômico e político, é inegável, em regra, o registro de um considerável avanço democrático ${ }^{154}$, nos últimos anos, salvo exceções tais como os acontecimentos que levaram ao chamado "autogolpe" perpetrado por Alberto Fugimori no Peru, até sua renúncia e restauração democrática.

Práticas até então anteriormente exclusivas do sistema parlamentar, tido como o mais evoluído politicamente, vão se incorporando ao modus vivendi do presidencialismo latino-americano, tais como as Comissões Parlamentares de Inquérito ou a possibilidade de o Congresso censurar atos do Ministério. Sob este aspecto, importante tem sido a cláusula democrática existente no tratado de Assunção, inviabilizando, há alguns anos, um golpe no Paraguai.

Quanto ao MERCOSUL, este deve sua existência, como já analisado no Capítulo I,1, pela vontade dos então governantes de seus Estados-Partes e, sob a vontade de seus governantes, tem ora aumentado o ritmo de integração, ora estagnado este ritmo, tornando-se, pois, importante uma análise do sistema presidencialista, dentro de seus Estados-Membros.

\footnotetext{
${ }^{154}$ Wagner Menezes salienta que "a América Latina é um manancial de princípios, teses e teorias, de práticas e institutos, de organismos, e que, por essa razão gerou um princípio fundamental para a concepção das relações internacionais contemporâneas que influencia toda a sociedade internacional: o princípio da Solidariedade". (MENEZES, Wagner, Direito Internacional na América Latina, Curitiba: Juruá, 2007. p. 24)
} 


\section{CAPÍTULO IV}

\section{O PRESIDENCIALISMO NOS PAÍSES DO MERCOSUL ${ }^{155}$}

Nos Estados-Partes do MERCOSUL, o presidencialismo, sob várias formas, esteve presente na maior parte de suas histórias como Estados independentes e em praticamente todo o século $X X^{156}$, sendo o sistema adotado, quando da criação do MERCOSUL, em 1991. Independentemente de ser o regime presidencialista um fator de integração no âmbito do MERCOSUL, ele exerceu e exerce um papel preponderante nas relações internas e internacionais no chamado "Cone Sul". Boa parte do que estes países são hoje, está profundamente calcada na construção deste sistema jurídico, daí a importância de conhecer a história destes países, pelo viés presidencialista e, também, as relações formais de poder tanto em âmbito local, como a partir do Tratado de Assunção.

\section{ARGENTINA}

$\mathrm{Na}$ Argentina, o sistema com feição presidencialista inicia-se com o governo de Bernardino Rivadavia, de 1826 a 1827, mas interrompe-se, logo em seguida, com sua renúncia ${ }^{157}$.

${ }^{155}$ A parte histórica, adaptada, com modificações, do texto: WINTER, Luís Alexandre Carta. A crise do modelo presidencialista no âmbito do MERCOSUL, ob. cit., p. 43-85.

${ }^{156}$ No Brasil, exceto entre 1961-1963, onde vigorou o sistema parlamentarista e, no Uruguai entre 1951-1966, onde vigorou um sistema colegiado.

${ }^{157}$ Atualmente, pela Constituição de 1994, para dar um continumm em termos de história, o art. 35 assim se posiciona: "Las denominaciones adoptadas sucesivamente desde 1810 hasta el presente, a saber: Provincias Unidas del Río de la Plata; República Argentina, Confederación Argentina, serán en adelante nombres oficiales indistintamente para la designación del Gobierno y territorio de las provincias, empleándose las palabras 'Nación Argentina' en la formación y sanción de las leyes". 
O processo de independência Argentina, largamente influenciado pelas guerras napoleônicas, inicia-se verdadeiramente com a deposição do Vice-Rei Espanhol Baltazar Hidalgo de Cisneros, em 1810, substituído por uma Junta de governo ${ }^{158}$.

Formalmente, a independência foi declarada no Congresso de Tucumán, a 9 de julho de 1816 e em 1819 o Congresso determinou a "Constituição das Províncias Unidas da América do Sul", sancionada a 22 de abril, que introduzia o bicameralismo, organizava o Judiciário, estabelecia a religião católica como oficial, criava o sistema censitário e a eleição do Diretor (chefe do poder Executivo) pelas duas câmaras.

Um poder central, instalado em Buenos Aires, em 1816, comandado por um diretor supremo, teve dificuldades para impor sua hegemonia sobre o resto do país. Liderada por José Gervásio Artigas, apoiado pelas massas rurais e defensor de um programa de reforma agrária, a corrente federalista do litoral manteve uma árdua luta contra Buenos Aires. Artigas, em 1815, deteve o controle não só das províncias litorâneas, mas também de Córdoba e Missões, controlando as rotas que ligavam Buenos Aires ao interior ${ }^{159}$.

${ }^{158}$ Amado Luiz Cervo sustenta que "Fernando VII, ao recuperar o trono em 1814, repeliu quaisquer princípios democráticos que haviam aflorado na Espanha e na América Espanhola. Por isso instalou-se em Buenos Aires, a 31 de janeiro de 1813, a Assembléia Geral Constituinte, que legitimou um triunvirato (Várias lideranças, por Buenos Aires, Artigas, pelo Uruguai e Francia, pelo Paraguai). O dilema platino entre centralismo e federalismo não se resolvia: este último era exigência inegociável de José Gervasio Artigas, o líder da revolução no Uruguai, ao passo que Francia, no Paraguai sequer o aceitava e desejava o isolamento de todos". (CERVO, Amado Luiz. A dimensão regional e internacional da independência. In: CERVO, Amado Luiz (Org.). História do Cone Sul. Brasília: UNB, 1998. p. 85)

159 José Luis Bendicho Beired sustenta que "a independência não se traduziu em estabilidade político institucional. O novo Congresso dividiu-se em função de um debate sobre a melhor forma de governo: república ou monarquia. Houve diversas tentativas frustradas para a implantação de uma monarquia. A princesa espanhola Carlota Joaquina, mulher de D. João VI, recebeu um convite para assumir o trono argentino, mas não aceitou por pressões da Inglaterra e da corte portuguesa. [...] A Constituição redigida em 1819, não conseguiu resolver o impasse entre republicanos e monarquistas. Estabeleceu um poder executivo unipessoal, que com uma pequena reforma da 
Com a renúncia de Bernardino Rivadavia, e em razão das intrigas entre federalistas e unitários, o governo se torna inoperante. Juan Manuel Rosas é nomeado governador de Buenos Aires, em 1829, em substituição a Manuel Dorrego e dá início a uma fase de autoritarismo e de conflitos generalizados com o interior, os europeus e o Brasil, até ser afastado, em 1852. As províncias do interior e Buenos Aires estão rompidas. É a guerra civil.

Em 1828, foi assinada a paz com o Brasil, constituindo-se um novo Estado independente a República Oriental do Uruguai, na outrora província Cisplatina, que na época ninguém acreditava viesse a sobreviver.

Após a renúncia de Rivadávia, foi reconstituída a província de Buenos Aires, governada pelo líder dos Unitaristas, então chamado Partido da Ordem, depois derrubado e executado pelo exército que regressara da Banda Oriental; o regime militar instaurado, por sua vez é derrotado ${ }^{160}$ pelos caudilhos. Entre eles, a figura dominante é Rosas.

Carta poderia transformar-se em poder monárquico hereditário. De caráter oligárquico e unitário, essa Constituição mal teve tempo de funcionar. As investidas dos caudilhos federais litorâneos puseram fim ao poder central em 1820. O país fragmentou-se e ficou dividido em nove províncias autônomas. Tentativas de criar um novo governo nacional desembocaram na criação do cargo de presidente da República em 1826, ocupado por Bernardino Rivadávia, e na aprovação pelo Congresso Nacional, que se reunia desde 1824, de uma Constituição de princípios liberalunitários. A província de Buenos Aires e sua capital foram postas sob controle das autoridades nacionais, as rendas da aduana de Buenos Aires foram nacionalizadas, beneficiando as outras províncias, foram criados exército e tesouro e definido o território sob jurisdição do governo, republicano e representativo". (BEIRED, José Luis Bendicho. Breve História da Argentina. São Paulo: Ática, 1996. p. 32-33)

${ }^{160}$ Halperin Donghi discorre que "à execução de Dorrego, seguiu-se um governo militar que fez sentir com dureza o seu peso sobre as regiões rurais cansadas da guerra, fato que provocou uma revolta rural que reconheceu como seu chefe Juan Manuel de Rosas, rico proprietário do sul, organizador de uma eficiente milícia regional em sua localidade fronteiriça. Após seis meses, o regime militar de Buenos Aires caiu e abriu-se para Rosas o caminho do poder. Nesse meio tempo, o movimento hostil aos federalistas obtinha maiores êxitos no interior, onde o General Paz, um veterano da guerra contra o Brasil e oriundo de Córdoba, se assenhorava de sua província e derrotava Facundo Quiroga, de La Rioja, obrigando-o a refugiar-se em Buenos Aires. Nove províncias caíram sob seu domínio, enquanto as quatro províncias litorâneas alinhavam-se contra ele. Capturado em uma ação de surpresa, o General Paz, em 1831, os federalistas reconquistam o interior e a Argentina volta a ser um conjunto de províncias dominadas por Rosas, López (governador de Santa Fé) e Quiroga". (DONGHI, Halperin. História da América Latina. Rio de Janeiro: Paz e Terra, 1975. p. 119) 
Rosas governou a província até 1852, com um breve intervalo, entre 1832 e 1835. Transformou-se no mais poderoso dos caudilhos de sua época, exerceu seu governo de forma autoritária e perseguiu de forma implacável seus opositores.

Rosas desenvolveu uma política guiada pelo objetivo de apaziguar a ininterrupta guerra civil entre os poderosos caudilhos do litoral e do interior. Por meio de alianças militares, derrotou as forças políticas contrárias ao federalismo e construiu um sistema de poder estável, baseado em pactos com caudilhos regionais. Essa estrutura de poder, denominada Confederação Argentina, também conhecida como Confederação Rosita, pois apesar de seu discurso federalista, Rosas impôs, na prática, o domínio dos interesses de Buenos Aires sobre o interior e o litoral, o que acabou por gerar novas tensões e guerras interprovinciais.

Juan Manuel de Rosas, em 1831, organizou a Confederação Argentina. Após duas décadas de sangrentas lutas, capital e o interior chegavam a um modus vivendi, com Rosas tornando-se, na prática, governante do País, embora tivesse recebido das demais províncias apenas a delegação formal para representá-las externamente. A Lei de aduanas, de 1835, por ser protecionista, favoreceu a burguesia mercantil portenha pela concentração do comércio exterior argentino no porto de Buenos Aires, cujas rendas não foram nacionalizadas ${ }^{161}$.

As pretensões hegemônicas de Buenos Aires ${ }^{162}$ com relação à Confederação geraram a reação que terminou por derrubar Rosas do poder. Ao

${ }^{161}$ Francisco Fernando Monteoliva Doratioto argúi que "Rosas não era contra a centralização política, mas não aceitava o liberalismo e seus defensores, os unitários, portadores dos valores laicos do humanismo e do progresso. Rosas 'nunca fue un verdadero federalista' e, sob a aparência de uma Confederação, estabeleceu um poder centralizado, favorecendo o domínio de Buenos Aires sobre as demais províncias argentinas". (DORATIOTO, Francisco Fernando Monteoliva. Formação dos Estados Nacionais e expansão do capitalismo no século XIX, artigo publicado na História do Cone Sul, Brasília: UnB, 1998. p. 177)

162 Há, historicamente, uma grande rivalidade entre Buenos Aires e o interior. Sobre esse assunto ver VEIGA GARCIA, Emanuel da. As Duas Argentinas. São Paulo: Ática, 1990. 
longo da década de 1840, formou-se uma aliança antiportenha no litoral, liderada pelo general Justo J. de Urquiza, governador de Entre Rios. Em 1852, Rosas foi derrotado na Batalha de Monte Caseros, por uma aliança internacional composta por Corrientes, Entre Rios, Brasil e Uruguai.

Em 1853 era aprovada uma nova Constituição, sem a participação de Buenos Aires ${ }^{163}$. De conteúdo liberal, estabeleceu a forma representativa, republicana e federativa de governo, a divisão dos poderes em legislativo, executivo e judiciário, a eleição indireta para presidente, direitos individuais, liberdade de culto paralelamente à adoção do catolicismo como religião oficial do Estado.

No mesmo ano, o general Justo José de Urquiza foi eleito presidente da República para um mandato de seis anos. Liberal e federalista, realizou uma política que atendeu aos interesses do interior. Buenos Aires insurge-se com a nova disposição e rompe com a Confederação em 1852, e, entre 1859 e 1862, trava batalhas com a Confederação que termina com a vitória das forças portenhas, comandadas por Bartolomé Mitre.

Mitre assumiu a presidência e deu início à estruturação de um Estado efetivamente nacional. Criou um Congresso Nacional, uma Justiça Federal, um Exército Nacional ${ }^{164}$ e implementou um programa liberal unitário com forte poder

\footnotetext{
${ }^{163}$ Juan Bautista Alberdi lembra que "depois da queda de rosas, Buenos Aires, para surpresa de toda América que a observava, continuou resistindo à criação de um governo nacional, que naturalmente relevava porque tinha de relevar seu governador local da qualidade de chefe supremo de catorze províncias, as quais não o elegeram nem tinham o direito de deixá-lo como responsável. Buenos Aires resistiu à criação de um Congresso Nacional, porque esse Congresso iria relevar sua legislatura de província dos poderes supremos de fazer a paz e a guerra, de regular o comércio e a navegação, de impor tarifas alfandegárias: poderes que essa província estava exercendo por sua legislatura local devido à ausência de um Congresso comum". (ALBERDI, Juan Bautista. Fundamentos da Organização Política da Argentina. Campinas: Unicamp, 1994. p. 151)

${ }^{164}$ Alain Rouquié salienta que "la presidencia de Mitre (1862-1868) abrió el camino a la modernización acelerada del país. Su obra militar puso los cimientos de una organización centralizada de la defensa nacional. El ejército estaba formado por la Guardia Nacional, milicias
} 
centralizador e derrota os caudilhos que se opunham a ele.

Mitre é sucedido por Domingos Faustino Sarmiento, que por sua vez é

sucedido por Nicolás Avellaneda e, em seu mandato, o Congresso aprovou a

federalização da cidade de Buenos Aires, separando-a da província e

transformando-a na capital do País. Houve um levante por parte de Buenos Aires,

mas foram derrotados e, desde então, Buenos Aires é a capital federal do País e La

Plata a sede do governo de província. Nicolás Avellaneda é sucedido pelo General

Júlio Argentino Roca, em 1880, o mais jovem presidente do País, com 37 anos ${ }^{165}$.

Roca, mediante a criação de uma aliança política denominada Liga dos

Governadores, cria-se um sistema político oligárquico ${ }^{166}$ em que as eleições não cumpriam outra função senão a de ratificar os candidatos oficiais ${ }^{167}$.

burguesas, y por 'la línea'. El proyecto de Mitre, interrumpido y atrasado por la guerra del Paraguay y por numerosos levantamientos en el interior del país, que lo obligaron a movilizar a los guardias nacionales, consintió en transformar a éstos en reserva de los cuerpos de línea que formarían el ejército activo propiamente dicho". (ROUQUIÉ, Alain. Poder Militar Y Sociedad Política en la Argentina. Buenos Aires: Emecé, 1978. v. I, p. 76)

165 Alain Rouquié ressalta que Roca, "quando ainda era apenas um colegial, ele se engaja nas tropas nacionais contra a secessão da província de Buenos Aires, e ganha sua patente de tenente em Cepeda (1859), dois anos mais tarde participa da batalha de Pavón, duas grandes datas da história das guerras civis argentinas. Com vinte e nove anos ele se torna coronel, por sua ação contra a rebelião de um caudilho provinciano, e finalmente torna-se general em conseqüência de uma vitória contra uma rebelião dirigida pelo general Mitre, antigo presidente". (ROUQUIÉ, Alain. O Estado Militar na América Latina. São Paulo: Alga-Ômega, 1984. p. 86)

${ }^{166}$ Boris Fausto e Fernando Devoto discorrem que "tratava-se de um sistema político que, na prática, foi se fechando em negociações de cúpula e no qual o papel do eleitorado, em parte indiferente, em parte estrangeiro (portanto, sem direito a voto), em parte manipulado por caudilhos locais e pressionado por todo tipo de fraudes e violências, era muito restrito. Além disso, esse reduzido eleitorado escolhia os representantes do Colégio Eleitoral que, por sua vez, deviam eleger o presidente, sem que se comprometessem a votar neste ou naquele candidato, embora o voto no Colégio Eleitoral costumasse se unânime no âmbito de cada distrito. Essa brecha dava lugar a todo tipo de arranjos, que se realizavam fora do Colégio Eleitoral, mas depois se projetavam nele. Uma instância, aliás, na qual a cidade e a província de Buenos Aires continuavam em notário minoria (em 1886 detinham juntas, apenas 58 das 232 cadeiras). Para que se tenha noção da crescente hegemonia do grupo dominante, basta lembrar que, em 1879, Roca obteve $69 \%$ do total de cadeiras do Colégio; em 1886, Juárez Celman obteve 79\% e, em 1892, Luis Sáenz Pena (um candidato fraco, indicado por Roca), 95\%". (FAUSTO, Boris; DEVOTO, Fernando. Brasil e Argentina - Um ensaio de história comparada (1950-2002). São Paulo: Ed. 34, 2004. p. 141)

167 José Luis Bendicho Beired (ob. cit., p. 46) sustenta que "a aliança feita por Roca deu origem a uma classe dominante nacional cuja fração mais poderosa era a burguesia terratenente pampeana, em particular a da Província de Buenos Aires. Nessa pedida, pode-se dizer que a federalização de Buenos Aires, em vez de representar a derrota da burguesia portenha e buenairense, significou a universalização dos seus interesses, valores e objetivos, por exemplo, a 
A nova elite dirigente ${ }^{168}$ consolidou o sistema agroexportador, promovendo uma profunda remodelação física do País ${ }^{169}$, em particular com as grandes cidades.

Se o regime conservador apostou na passividade política da população, cujo

lema político era "paz e administração", com o surgimento de reivindicações das

classes média e operária por participação política, os conservadores reformaram o

regime em 1912, estabelecendo o sufrágio universal masculino, secreto e obrigatório

para maiores de 18 anos e, ao contrário do que os conservadores esperavam, essa

lei os desalojou do poder ${ }^{170}$, elegendo-se Hipólito Yrigoyen, em $1916^{171}$. Este foi

defesa da grande propriedade e da criação de gado, o culto do progresso indefinido e a estreita vinculação econômica e cultural com a Europa".

168 "essa elite também era obcecada pela ordem pública e por sua perpetuação no poder. Os futuros presidentes, governadores e prefeitos tinham seus nomes definidos previamente no círculo dos donos do poder". (BEIRED, José Luis Bendicho. Ob. cit., p. 46)

169 Boris Fausto e Fernando Devoto (ob. cit., p. 139-140) ressaltam que a Argentina entrou nos anos 1880 numa fase de notável expansão. "Muitas causas contribuíram para isso: a alta dos preços internacionais de seus produtos agropecuários; o surgimento de uma nova tecnologia para a exportação de carne; o retorno ao mercado internacional de capitais; a chamada conquista do deserto, na qual foram anexadas grandes extensões de terras em poder dos índios no Centro-Sul e no Nordeste do país; a solução da questão da capital e o fim das guerras internas. Basta assinalar que a expansão da fronteira agropecuária permitiu a incorporação de milhões de hectares à produção (por exemplo, a área plantada com trigo e milho passou de 200 mil hectares, em 1872, para 1,6 milhões em 1888)".

170 Luiz Moniz Bandeira discorre que "ao culminar, nos anos que se seguiram à Guerra da Tríplice Aliança (1864-1870), o processo de formação e consolidação do Estado nacional, com a centralização do poder e a unificação do seu espaço econômico, a Argentina entrou em uma era de prolongada estabilidade política, apesar dos levantes que ocorreram em algumas províncias e mesmo em Buenos Aires, provocando a intervenção do governo federal. De qualquer forma, de 1880, ano em que o Presidente Nicolas Avellaneda, com o apoio do General Julio A. Roca derrotou a rebelião autonomista de Buenos Aires e promoveu a sua federalização, isto é, a apropriação da cidade, como capital do País, e do porto pelo Governo da República, até 1930, o poder civil sufocou os levantes político-militares de 1890 (Buenos Aires), 1893 (San Luís, Rosário, Santa Fé, Mendoza e Córdoba) e sempre prevaleceu, a sustentar a ordem legal e o funcionamento das instituições. Os governos se sucederam, dentro do arcabouço democráticorepresentativo da Constituição, e o Presidente Roque Saenz Peña (1910-1916) realizou a reforma que implantou o sufrágio secreto e universal, possibilitando a eleição de Hipólito Yrigoyen, em 1916, e a ascensão ao poder do Partido Radical, formado em meio da crise de 1889-90 e que desde aquela época representou a oposição. [...] Em 6 de setembro de 1930, depois de meio século de estabilidade institucional e predomínio do poder civil, o General José F. Uriburu desfechou vitoriosamente um golpe de Estado na Argentina e derrubou o Governo do Presidente Hipólito Yrigoyen, eleito, em 1928, para um segundo mandato pelo Partido Radical. [...] Uriburu convocou eleições, em 1931, e passou o poder ao General Agustín P. Justo, sufragado por uma coligação, 'Concordância', que os conservadores dominaram e com a qual dirigiram a Argentina, sem prejuízo dos aspectos formais da mecânica democrático-representativa, até o putsch de 1943". (MONIZ BANDEIRA, Luiz. Estado Nacional e Política Internacional na América Latina. 2. ed. São Paulo: Ensaio, 1995. p. 21-22) 
sucedido por Marcelo T. de Alvear, em 1922. Yrigoyen volta ao poder em $1928^{172}$, derrubado pelos militares em $1930^{173}$.

O regime civil é restaurado em 1932, com Agustín P. Justo, continuando com o predomínio de políticos conservadores. Em 1943, um novo golpe militar, derrubando-se o Presidente Ramón S. Castillo, abre caminho para o coronel Juan Domingo Perón, secretário do Trabalho ${ }^{174}$, que se fortalece favorecendo a

${ }^{171}$ Luis Alberto Romero ressalta que "em 12 de outubro de 1916, Hipólito Yrigoyen assumiu a Presidência da Argentina. Foi um dia excepcional: uma multidão tomou a Plaza del Congreso e as ruas próximas para aclamar o primeiro homem eleito pelo voto universal, secreto e obrigatório, de acordo com a nova lei eleitoral, sancionada em 1912, por iniciativa do presidente Sáenz Pena. [...] A decisão de Yrigoyen de modificar a atitude repressora tradicional do Estado, utilizando seu poder para mediar entre os diferentes atores sociais e, assim, equilibrar a balança, parecia aparar a última aresta de conflito". (ROMERO, Luis Alberto. História Contemporânea da Argentina. Rio de Janeiro: Zahar, 2006, p. 13)

${ }^{172}$ Félix Luna ressalta que nesta eleição "ocurrió una suerte de empate. Los ochocientos mil votos que había obtenido el radicalismo en 1928 bajaron a seiscientos mil, y la oposición, que había tenido unos cuatrocientos mil votos, subió a la misma cifra. Pero el hecho sin precedentes desde el punto de vista electoral fue que, en la Capital Federal, el radicalismo perdió ante un partido que era la minoría ante un partido que era la minoría de otro partido minoritario. Perdió, en efecto, frente al Partido Socialista Independiente, una disidencia del viejo Partido socialista tradicional, mucho más antiyrigoyenista que éste y que en su momento se aliaría a los conservadores para formar lo que después se llamó la Concordancia. La derrota del radicalismo en la Capital Federal a manos de un partido tan improvisado fue un toque de atención. A partir de ese momento empezó a plantearse la conspiración militar de la que se había hablado un par de años antes, cuando la victoria de Irigoyen despertó algunas inquietudes. Entonces se había tanteado al general Justo, ministro de Guerra del presidente Alvear, pero el militar opinaba, frente al reciente triunfo plebiscitario de Yrigoyen, que toda forma de revolución habría sido repudiada. Sin embargo, en 1930 las cosas ya habían cambiado, y la conspiración militar se puso en marcha, encabezada por el general José Félix Uriburu, de origen salteño, quien había sido diputado conservador en 1913". (LUNA, Félix. Breve Historia de los Argentinos. Buenos Aires: Planeta, 1998. p. 166-167)

${ }^{173}$ Boris Fausto e Fernando Devoto (ob. cit., p. 241) relatam que "o golpe de Estado de 6 de setembro de 1930, na Argentina, dependeu de um acordo entre os dois maiores chefes militares, os generais Justo e Uriburu. Justo era uma figura mais próxima dos dirigentes políticos liberalconservadores, e dele se poderia esperar uma 'retificação de curso', imposta pelos males produzidos por Yrigoyen, e não uma 'revolução'. Já Uriburu, apoiado calorosamente pelos nacionalistas, tinha confusas aspirações e acenava para a instituição de um regime nacionalcorporativo, nos moldes dos que estavam em vigor na Europa, embora predominasse sua incerteza quanto aos rumos a tomar na implantação do sistema político".

${ }^{174}$ Mas que também acumulava a Vice-Presidência e o Ministério da Guerra. Segundo Ana Maria dos Santos lembra, "em outubro de 1943, o coronel Juan Domingo Perón se colocou à frente do Departamento de Trabalho e Previdência, e dali procurou organizar o movimento dos trabalhadores em benefício do projeto político do seu grupo. Ofereceu postos governamentais a líderes sindicais, promulgou 29 leis trabalhistas novas, tomou parte em 311 disputas, arbitrando 174 , concedeu aumentos salariais e o $13^{\circ}$ salário. Ao mesmo tempo, promoveu a formação de sindicatos paralelos e a intervenção na CGT, prendeu 48 líderes sindicais e perseguiu sindicatos que se recusavam a colaborar". (SANTOS, Ana Maria dos. América Latina: dependência, ditaduras e guerrilhas. In: REIS, Daniel Aarão Filho (Org.). O século XX O Tempo das Dúvidas Do declínio das utopias às globalizações. Rio de Janeiro: Civilização Brasileira, 2000. v. III, p. 72) 
sindicalização e promovendo reformas trabalhistas.

A influência de Perón ${ }^{175}$ entre os trabalhadores leva os militares a afastá-lo do ministério em 1945, mas manifestações populares forçam o Exército a chamá-lo de volta ${ }^{176}$.

Eleito presidente em $1946^{177}$, Perón casa-se com Eva Duarte (Evita), figura central da propaganda de seu governo populista. O Partido Peronista é fundado em 1948 e Perón, reeleito em 1951.

Com a morte de Evita, em $1952^{178}$, enfraquece o governo, que entra em atrito com vários setores da sociedade. Deposto em setembro de 1955, por um golpe militar, Perón exila-se na Espanha, enquanto o governo provisório, chefiado pelo general Pedro Aramburú, desencadeia repressão aos peronistas.

Mesmo na ilegalidade, o peronismo ajuda Arturo Frondizi ${ }^{179}$ da ala esquerda

${ }^{175}$ Alain Rouquié ressalta que "El coronel Perón cuidaba su imagen desde que había sido nombrado en el Departamento del Trabajo. Caluroso, directo y familiar, quien sería bautizado más adelante como 'el hombre con una sonrisa siempre en los labios' sabía emplear sus cualidades personales. Acogedor con los sindicalistas, protector y atento con los humildes, el paternalismo que empleaba con ellos era militar: parecía el padre del regimiento a nivel de toda la nación". (ROUQUIÉ, Alain. Poder Militar y Sociedad..., v. II, p. 49)

${ }^{176}$ Octavio lanni (ob. cit., p. 80-81) discorre que "na Argentina, o peronismo começa com base no sistema sindical preexistente, mas o amplia e redefine, fazendo-o diferenciar-se cada vez mais das organizações políticas e sindicais controladas ou influenciadas pela esquerda. O 'partido peronista' foi decisivamente dominado pelas figuras de Juan Domingo Perón e Eva Perón, quando se desenvolveu bastante a liderança carismática. Aliás, como Eva Perón, ou Evita, a liderança carismática típica do populismo latino-americano atingiu uma das suas manifestações mais avançadas. No peronismo também estiveram presentes setores militares e empresariais, além de alguns segmentos da classe média. Em sua primeira fase, o populismo argentino, amplamente apoiado por esses setores militares, do qual saíra o próprio Cel. Perón, esteve comprometido com a idéia da 'pátria grande'. A grande Argentina liderando uma parte da América do Sul era o sonho de alguns militares peronistas".

177 Apesar da oposição americana.

${ }^{178}$ Para se transformar na santa dos descamisados.

${ }^{179}$ Félix Luna alerta que "uma das pesadas desvantagens com que Frondozi devia arcar era a exagerada expectativa que suscitara e as esperanças desmedidas que despertava. Em maio de 1958 todos aguardavam soluções rápidas para suas próprias dificuldades. O novo presidente compreendia que tais expectativas logo sofreriam o confronto com uma realidade angustiante e por isso decidiu assegurar-se uma margem de tranqüilidade social antes de iniciar as grandes batalhas pelo desenvolvimento. Determina um aumento maciço de $60 \%$ sobre os acordos coletivos vigentes. Foi apontado como comunista". (LUNA, Félix. Argentina: de Perón a Lanusse 
da UCR a se eleger presidente em 1958 e, quatro anos depois, Frondizi é deposto pelos militares. Arturo Illia (UCR), eleito presidente em 1963, é deposto em $1966^{180}$, em um golpe liderado pelo general Juan Carlos Onganía.

Violentas manifestações populares e o surgimento de grupos guerrilheiros levam os militares a afastar Onganía, em $1970^{181}$. Seu sucessor, Roberto Levingston, é substituído em 1971, pelo general Alejandro Lanusse, que inicia negociações para a volta de Perón.

O peronista Héctor Cámpora, eleito presidente em março de 1973 e empossado em maio, renuncia dois meses depois para permitir a candidatura de Perón.

O Partido Justicialista (Peronista), mesmo elegendo Perón em setembro, divide-se, em meio a crise, entre montoneros (esquerda) e anticomunistas. Perón morre em julho de 1974, Isabelita, sua mulher e vice-presidente, assume o governo, apoiada pelo seu secretário, López Rega, que favorece setores direitistas, enquanto as atividades terroristas se intensificam.

Isabelita é deposta por um golpe, em março de $1976^{182}$. Uma junta militar

(1943-1973). Rio de Janeiro: Civilização Brasileira, 1974. p. 117)

180 Emílio Dellasoppa lembra que "a queda do governo Illía foi das mais intensamente 'negociadas' entre os setores corporativos fundamentais da sociedade argentina: Forças Armadas, empresários e sindicatos. [...] Nesse contexto deve ser analisado o excepcionalmente alto número de greves sob o governo radical, como as ocupações de fábricas com seqüestro de proprietários e funcionários hierarquizados". (DELLASOPPA, Emílio. Ao inimigo, nem Justiça - violência política na Argentina 1943-1973. São Paulo: Hucitec, 1998. p. 270)

181 Alain Rouquié (O Estado Militar na América Latina, p. 323) salienta que na Argentina "a nãocoincidência entre a orientação dominante do Exército e a do governo civil leva a uma instabilidade permanente". Segundo Félix Luna (ob. cit., p. 185 e 193), a queda de Onganía, deuse mais do que os movimentos extremistas, pela explosões da impaciência popular, principalmente da classe média, com o plano Krieger Vasena, ministro da economia, que, em nome da estabilidade monetária, redução da inflação e nivelamento orçamentário, após dois anos de sucesso, causa a descapitalização dos setores produtivos nacionais, a falta de defesa da indústria nacional, a ausência de investimentos em setores básicos e a liquidação de fontes de trabalho.

182 Alain Rouquié (O Estado Militar na América Latina, p. 321) salienta que "de 1930 a 1973 , 
chefiada pelo general Jorge Rafael Videla assume o poder, dissolve o Congresso e os partidos e dá início à guerra suja, repressão sistemática aos oposicionistas, que faz mais de 10 mil desaparecidos.

A política econômica ultraliberal do ministro da Fazenda, Martinez de Hoz, desmantela o parque industrial argentino. O General Roberto Viola substitui Videla na Presidência, em 1981, prometendo dialogar com a oposição, mas é deposto por um golpe liderado pelo comandante do Exército, general Leopoldo Galtieri.

Na iminência de perder o controle do País, os militares tentam recuperar o apoio popular ordenando, em março de 1982, a invasão das Malvinas, território britânico, reivindicado pela Argentina.

apoio inicialmente obtido, transforma-se em indignação diante da derrota para os britânicos, que reocupam o arquipélago em junho. Galtieri renuncia em julho $^{183}$. Seu substituto ${ }^{184}$, general Reynaldo Bignone, negocia o retorno dos civis ao

nenhum presidente eleito no quadro de uma sucessão normal conseguiu cumprir seu mandato constitucional. A propensão dos militares para se instalarem na Casa Rosada, sede do Executivo, merece ser assinalada: entre quinze presidentes que a Argentina teve nesse período, onze eram militares. Ainda mais singular do que isso, é o fato de que apenas dois dos presidentes eleitos conservaram o poder até o término de seus mandatos legais: e ambos eram generais".

183 José Luis Bendicho Beired (ob. cit., p. 78) lembra que, "desde 1833, havia um litígio entre a GrãBretanha e Argentina pela soberania das ilhas Malvinas (Falkland, para os ingleses), localizadas no extremo sul do país. Durante o período colonial, ingleses e espanhóis alternaram-se na ocupação das ilhas, colonizadas primeiramente pela Grã-Bretanha a partir de 1765. Quando ocorreu a independência das colônias espanholas, as ilhas passaram para o domínio argentino, pois na época estavam ocupadas pelos espanhóis. Porém, em 1833, os ingleses retomaram o controle das ilhas, que desde então são reivindicadas pela Argentina".

${ }^{184}$ Luis Alberto Romero lembra que "a derrota agravou a crise do regime militar, anunciada desde o caos financeiro de 1981, e fez com que viessem a público conflitos que, até então, eram dissimulados. A questão da responsabilidade da derrota [...] o relatório de uma comissão investigadora presidida por um general de muito prestígio responsabilizou a própria Junta Militar e a levou a um julgamento que, posteriormente, condenou os comandantes. Naquele instante, as três forças não entraram em acordo sobre o sucessor de Galtieri, e, apesar de o Exército ter conseguido impor seu candidato, o general Reinaldo Bignone, a Marinha e a Aeronáutica se retiraram da Junta Militar, criando uma situação institucional insólita: um presidente designado pelo comandante-chefe do Exército. Talvez tivesse sido o momento para que um vigoroso movimento civil depusesse as Forças Armadas, mas tal movimento estava longe de existir, e o presidente nomeado conseguiu se firmar graças a um consenso mínimo de forças políticas em torno de um programa de reinstitucionalização sem prazos definidos. Passado o momento mais grave da crise, houve uma recomposição interna, os comandantes da Marinha e da Aeronáutica 
poder $^{185}$.

Raul Alfonsín, da UCR, eleito presidente em 1983, ordena a prisão dos comandantes das juntas militares, em 1984. Em 1985 e 1986, cinco membros das juntas e os chefes da campanha das Malvinas são condenados a penas que vão de quatro anos à prisão perpétua.

A hiperinflação provoca saques e quebra-quebras. Em 1987 e 1988, revoltas de militares da ativa (os cara-pintadas) ${ }^{186}$ contra o julgamento de oficiais levam Alfonsín a enviar ao Congresso a Lei da Obediência Devida, que anistia os oficiais subalternos, e a Lei do Ponto Final, que limita o número de processos, ambas revogadas em 1998. Em 1989, um frustrado assalto de radicais esquerdistas ao quartel de La Tablada, enfraquece o governo civil.

O peronista Carlos Menem vence as eleições presidenciais de 1989 e toma posse seis meses antes do fim do mandato de Alfonsín, em meio a uma grave crise econômica. Sufocando nova revolta de caserna em 1990, todavia indultando os militares da 'guerra suja', ele termina por ganhar a confiança do Alto Comando e uma grande oposição de parcela da população. No combate à inflação, lança em 1991 um plano baseado na paridade entre os valores do peso e do dólar, planejado

foram renovados, e a Junta reconstituída". (ROMERO, Luis Alberto. História contemporânea da Argentina. Rio de Janeiro: Zahar, 2005. p. 223)

185 José Luis Bendicho Beired (ob. cit., p. 76-77) discorre que, "na época do Processo de Reorganização Nacional, nome dado pelos militares ao regime político que vigorou entre 1976 e 1983, a sociedade argentina transformou-se em refém do Estado, que aplicou uma estratégia de repressão que pode ser plenamente qualificada de terrorismo de Estado. Posteriormente, os militares alegaram que era uma guerra, ou, como preferiam dizer, uma 'guerra suja'. Tradicionalmente, um indivíduo era preso e torturado por alguns dias, antes que sua detenção fosse legalizada e a família avisada".

${ }^{186}$ Francisco Viana lembra que "o primeiro levante dos carapintadas - que ganharam esse nome porque tingiam o rosto com graxa para não serem publicamente reconhecidos -, liderados pelo tenente-coronel Aldo Rico (abril de 1987), eclodiu num momento em que 450 militares, das Forças Armadas e dos órgãos de segurança, encontravam-se respondendo a processos. À crise da Semana Santa se seguiram duas outras: Monte Caseros (janeiro de 1988) e Villa Martelli (dezembro de 1988). Somadas, as rebeliões envolveram 1.450 militares". (VIANA, Francisco. Argentina, Civilização e Barbárie. São Paulo: Atual, 1990. p. 92) 
e executado pelo ministro da economia Domingos Cavallo. Subvertendo a ideologia populista-peronista, privatiza em 1992, o sistema energético e a empresa estatal de petróleo. Menem é reeleito em 1995, mas não consegue fazer seu sucessor. Nas eleições de 1999, é eleito Fernando de la Rúa, da UCR, uma coalizão de oposicionista que reunia a UCR e a Frente do País Solidário, mas, renuncia em 2001, antes do término de seu mandato, em face da crise econômica. De la Rúa é sucedido pelo presidente do Senado, Ramón Puerta, que renuncia dois dias depois, o Congresso Argentino elege Adolfo Rodriguez Saá, que renuncia oito dias depois. Saá é sucedido por Eduardo Camaño, que governa por dois dias, Camaño é sucedido por Eduardo Duhalde, escolhido pelo Congresso, Duhalde faz seu sucessor, Nestor Kirchner, em 2003 e Kirchner é sucedido por sua esposa Cristina Kirchner em 2007.

\section{BRASIL}

No Brasil, somente durante o governo de Floriano é que foram dadas as primeiras feições de uma República Presidencialista, ainda que sua proclamação tenha ocorrido em 1889.

À medida que países vizinhos ao Brasil proclamavam suas independências, a idéia republicana tomou impulso, tendo como modelo o sistema RepublicanoPresidencialista norte-americano, isto no final do século XVIII.

A experiência foi retardada em razão da vinda da Família Real, conseqüência direta das guerras napoleônicas. Mesmo assim, a Revolução de Pernambuco em 1817, a Confederação do Equador e o próprio período da Regência, tiveram nítidas conotações republicanas, sustadas pelo golpe da 
maioridade, por quarenta e nove anos. Com a Guerra do Paraguai, renasce a idéia republicana.

Em 1870, é fundado o primeiro clube e o primeiro jornal republicano, com o lançamento redigido por Aristides Lôbo e encabeçado por Saldanha Marinho, Quintino Bocaiúva e Salvador de Mendonça ${ }^{187}$.

Em julho de 1873, na cidade paulista de Itú, realiza-se o primeiro Congresso Republicano.

Desde o início, os republicanos brasileiros estavam divididos entre históricos e positivistas, este último bastante difundido nos meios acadêmicos e por Benjamin Constant, na Escola Militar.

Da Faculdade de Direito de São Paulo, irradia-se um movimento republicano que repercutirá no Rio Grande do Sul, ensejando a formação de um núcleo de tendências positivistas, no qual aparecerão Júlio de Castilhos, Assis Brasil, Borges de Medeiros, Demétrio Ribeiro e outros ${ }^{188}$.

A proclamação da República só ocorreu devido ao enfraquecimento da monarquia frente à questão religiosa e militar, além do fato da proximidade (1888) entre os chefes republicanos e os militares, dando início a uma conspiração contra o Império, na qual a ação militar foi decisiva, visto que o partido republicano não dispunha de uma estrutura suficientemente forte para realizar tal intento.

\footnotetext{
${ }^{187}$ BELLO, José Maria. História da República. 8. ed. São Paulo: Nacional, 1983. p. 16.

${ }^{188}$ Hélio Silva observa que o positivismo exercia grande atração sobre os republicanos e que, embora sonhassem - ou pelo menos parte deles - com um governo forte, estes "nunca se manifestaram francamente contra o sistema parlamentar". (SILVA, Hélio. Nasce a República. São Paulo: Três, 1975. p. 45, v. I, Coleção História da República Brasileira)
} 
Proclamada a República, seguiu-se o período conturbado do Governo Provisório. O antigo Império passava a denominar-se oficialmente de "Estados Unidos do Brasil", denotando-se a crescente influência norte-americana na implantação da nova forma de Governo.

O governo provisório ficou inicialmente constituído por Deodoro, como chefe, em conjunto com os seguintes ministros: Rui Barbosa, na Fazenda; Campos Sales, na Justiça; Demétrio Ribeiro, na Agricultura (que incluía a viação, indústria e comércio); Aristides Lôbo, no Interior; Quintino Bocaiúva, no Exterior; Eduardo Wandenkolk, na Marinha e Benjamin Constant, na Guerra.

Deodoro da Fonseca, como Ditador, manteria tal título até a Constituição de 1891, ao eleger-se, constitucionalmente, Presidente da República.

O primeiro Ministério durou até 20 de janeiro de 1891, data da renúncia coletiva, em virtude da discordância com o Marechal quanto à questão da obra no porto de Torres. Após este acontecimento, Deodoro incumbe ao barão de Lucena a reorganização do Governo e com isto, conservando os hábitos parlamentaristas existentes no Império, faz dele seu virtual primeiro ministro ${ }^{189}$.

A primeira eleição presidencial foi indireta, nos termos do artigo das disposições transitórias da constituição republicana, de forma que presidente e vice seriam eleitos em escrutínios separados pelo Congresso. Deodoro foi eleito por 129 votos contra 97 dados a Prudente de Morais, presidente da Constituinte. Floriano Peixoto era candidato a vice, na chapa de Prudente de Morais, recebendo 153 votos

${ }^{189}$ ARINOS, Afonso; QUADROS, Jânio. História do Povo Brasileiro. 2. ed. São Paulo: J. Quadros Ed. Culturais, 1968. v. V, p. 29. Como nos mostra Afonso Arinos de Melo Franco, "Lucena dominou o cenário político não só no fim da ditadura de Deodoro, mas durante todo o seu período constitucional de governo, encerrado com a renúncia de novembro de 1891. Ocupou, em um e outro período, várias pastas e foi o chefe efetivo, tanto da política quanto da administração". 
e derrotando o vice de Deodoro, o almirante Eduardo Wandenkolk, que recebera 57 votos.

O autoritarismo do Marechal Deodoro e o projeto de lei versando sobre a responsabilidade do Presidente da República aprovado pelo Congresso, em descompasso com seu veto, culminaram com o desentendimento entre ambos. Um poder, para sobreviver, tinha que destruir o outro, como de fato ocorreu ${ }^{190}$.

Primeiramente, Deodoro dissolveu o Congresso através de um golpe, mas este estimulou o contragolpe, obrigando-o a renunciar ${ }^{191}$.

Com a queda de Deodoro, assume o Marechal Floriano Peixoto, que trata de fortalecer o Poder Executivo às custas do Legislativo.

Os sonhos republicanos e federalistas do Brasil foram realizados com a Constituição de 1891, todavia ela torna possível o regime forte de Floriano, pois, embora rezasse em seu art. 42 que, "se, no caso de vaga, por qualquer causa, da presidência ou vice-presidência não houverem ainda decorrido dois anos do período presidencial, proceder-se-á a nova eleição", nas Disposições Transitórias, estatuía que "o Presidente e o vice-presidente eleitos na forma deste artigo ocuparão a Presidência e a vice-presidência durante o primeiro período presidencial". Floriano

190 Sahid Maluf (ob. cit., p. 284), com rara felicidade, expõe que "instituído o sistema republicano presidencial nos moldes da Constituição dos Estados Unidos, deferiu-Ihe o Marechal Deodoro o primeiro golpe, dissolvendo a Câmara dos Deputados e apontando aos representantes da soberania nacional o olho da rua. Desde então deveriam compreender os membros do Poder Legislativo, como se expressa Olímpio Ferraz de Carvalho, que 'o seu papel, no sistema presidencial, era o de servir e obedecer ao Chefe de Estado"'. Ainda Sahid Maluf, mais adiante, às fls. 284-285, comenta: "Rojas Paul, Presidente da Venezuela, comentado a queda do Império brasileiro, 'acabou-se a única República que existiu na América - o Império do Brasil'. Igualmente, o historiador norte-americano Jorge Crichfield, analisando a queda da Monarquia e a proclamação da República, comentou: 'assim terminou a única República que o Brasil já possuiu. ChamaramIhe Império. Depois, tiveram ditaduras e chamaram-Ihe Repúblicas"'.

${ }^{191}$ Começava assim, nas palavras de Afonso Arinos (ob. cit., p. 32) a "experiência presidencialista brasileira, que, daí por diante, se repetiu com sinistra monotonia: presidentes depostos e congressos dissolvidos ou coagidos por estados de exceção, sempre pela mesma causa, seja, a incapacidade do regime, de prazos fixos e posições rígidas, em transformar as oposições em governos". 
se ateve às Disposições Transitórias ${ }^{192}$

Floriano consolida a República Presidencialista, resistindo, à força da Revolução Federalista e da Revolta da Armada, com uma inquebrantável vontade e, ao findar de seu quadriênio, abandona literalmente o poder. Prudente de Morais, que sequer havia recebido do seu antecessor as informações sobre a marcha dos negócios do País, assume a Presidência da República envolto numa atmosfera de insegurança ${ }^{193}$.

Marcado pela divisão entre os republicanos, o Governo de Prudente de Morais tinha de um lado os reacionários, que defendiam a idéia de que ao Presidente da República cabia também as funções de chefe do partido e de que o Governo central poderia intervir nos Estados.

192 José Maria Bello (ob. cit., p. 89-90) a esta questão sustenta que "à sombra de duvidosa legalidade, resultante de uma interpretação muito mais política e oportunista do que jurídica, conservando-se na presidência, fazendo questão, todavia, de manter o título de Vice-Presidente". É irresistível a comparação de como a história, com novos atores, se repete: Tancredo Neves e José Sarney. Completando nova transição democrática, quase um século depois. O segundo, sucede ao primeiro em um arranjo mais político do que jurídico.

193 Therezinha de Castro bem ilustra esta peculiar situação: "Quando findava o Governo de Floriano, a Convenção do Partido Republicano Federal (25 de setembro de 1893) indicava o nome de Prudente de Morais para o seguinte quadriênio. Chegava ao Rio a 2 de novembro de 1894, já como Presidente eleito e, ao desembarcar na Central do Brasil, nenhum representante do Governo que se despedia do poder o fora aguardar na estação. Apenas o ajudante de ordens de Floriano, o Capitão Tenente Sadock de Sá, foi vê-lo à noite no Hotel dos Estrangeiros, onde se hospedara; segundo as próprias informações dadas por este oficial aos jornais da época, a sua visita fora unicamente para 'cumprimentá-lo em nome do Marechal Vice-Presidente da República'. Procurou Prudente de Morais avistar-se com Floriano, mas este não atendeu à solicitação do Presidente eleito para uma entrevista. No dia da posse, 15 de novembro de 1894, como não lhe mandaram um carro oficial, Prudente de Morais alugou um dos que estacionavam em frente ao hotel, na Praça José de Alencar, e seguiu para o Senado, onde realizou o ato de compromisso e posse. Daí partiu a pé para o Palácio Itamarati, em companhia dos membros do Congresso. $\mathrm{O}$ ambiente que encontrou foi o de casa abandonada, na mais completa desordem. Não havia sentinelas, nem guardas, e o povo movido pela curiosidade invadia as escadarias do edifício. Conta Rodrigo Otávio, testemunha ocular do ato, em seu livro Minhas Memórias dos Outros, que 'comprimido pelo povo, sem garantia de espécie alguma, chegou Prudente de Morais ao salão principal, onde pouco depois chegava o Ministro da Justiça e Interior do Governo que findava - Dr. Cassiano do Nascimento. Este, sem a menor cerimônia, dirigiu-se a Prudente de Morais dizendo que em nome do Marechal Vice-Presidente, Ihe transmitia o Governo. Assumia Prudente de Morais a Presidência"'. (CASTRO, Therezinha de. História da Civilização Brasileira. Rio de Janeiro: Capemi, 1982. p. 272-273) 
De outro lado, tem-se os federalistas, defensores de posições contrárias, ressaltando entre estes a figura de Campos Sales que, segundo seus princípios, afirmava: "a autonomia dos Estados é o coração da República"194 e batendo-se também pelo presidencialismo como a pedra fundamental do Governo republicano.

Para Campos Sales, o Conselho de Ministros e o parlamentarismo eram reminiscências monárquicas e, se na República havia os Secretários de Estado, o presidente não deveria subdividir com eles a sua autoridade legal e moral. Acabava por suceder a Prudente de Morais na Presidência da República ${ }^{195}$.

Contudo, ao assumir a Presidência da República, o próprio Campos Sales começa a intervir nas unidades federativas de um modo direto e incisivo, através da reforma do regimento da Câmara e com a política que empregou em relação aos governadores. Dentro desta nova República, as eleições para a Presidência passariam a se realizar sem oposição, sagrando-se vencedor o candidato situacionista apresentado pelo Governo. Este sistema centralista- oligárquico, de um presidencialismo ${ }^{196}$ personalista, perdurou até a revolução de 1930 . É a chamada Velha República ${ }^{197}$.

${ }^{194}$ CASTRO, Therezinha de. Ob. cit., p. 276.

195 Therezinha de Castro ressalva que "dos princípios enumerados por Campos Sales, depreende-se que ele lutaria pela república federalista contra a unitarista, pelo presidencialismo contra o parlamentarismo e, era, em suma, um adversário da política intervencionista nos Estados". Idem, p. 276

${ }^{196}$ Ernest Hambloch cita Rui Barbosa ao argumentar "nunca haver existido um Presidente nesta democracia republicana que pudesse ser feito responsável por qualquer de seus atos... Assim, o presidencialismo brasileiro nada mais é que uma ditadura em estado crônico, a irresponsabilidade geral, consolidada e sistemática do Poder Executivo". E vai além ao argüir que "as questões pessoais desde o estabelecimento da República tornaram-se a quintessência do que é chamado a política brasileira. Não existem programas políticos, e até a questão: 'Que programa adotaremos a fim de conseguir que o país nos coloque no poder?' não chega a surgir. A questão a ser decidida é apenas esta: 'Que elementos políticos devemos conciliar a fim de permanecer no poder ou, alternativamente, alcançá-lo?'" (HAMBLOCH, Ernest. Sua Majestade o Presidente do Brasil Um Estudo do Brasil constitucional (1889-1934). Brasília: UnB, 1981. v. 13, p. 72, Coleção Temas Brasileiros)

${ }^{197}$ Luiz Alberto Moniz Bandeira sintetiza a questão representada pela República Velha, adicionando a ela uma dimensão diferente e mais ampla. Sustenta que "o Brasil, ao contrário da Argentina, já 
O regime cada vez mais centralizado, malgrado a Constituição afirmar ser o

\author{
País uma República Federativa ${ }^{198}$, encontra seu apogeu na Emenda Constitucional
}

de setembro de $1926^{199}$ que, como diz Ernest Hambloch ${ }^{200}$, "fortaleceram o controle

emergira do regime colonial como um Estado unitário, desfrutara de plena estabilidade política quase todo o tempo do Império, no século XIX, e só teve sua ordem constitucional subvertida pelo golpe militar, que proclamou a República em 1889. Forte turbulência então ocorreu, entre 1891 e 1893, quando o Marechal Deodoro da Fonseca, fundador da República, renunciou à Presidência, após fechar o Congresso (1891) e seu vice, a sucedê-lo no governo, enfrentou a insurreição da Armada, no Rio de Janeiro (1893), enquanto uma guerra civil contra a administração provincial de Júlio de Castilhos se alastrava pelo Rio Grande do Sul e se estendia ao território de Santa Catarina, desbordando inclusive as fronteiras com a Argentina (Missões) e do Uruguai (18931894). Porém o Brasil não se desintegrou em duas ou mais repúblicas, com a separação do Rio Grande do Sul, conforme o Presidente do Uruguai, Máximo Santos, esperava, e de São Paulo, que os diplomatas britânicos previam e o Barão de Rothschild, como agente financeiro do País, estava a recear. Logo, o poder civil foi restaurado, com a eleição de Prudente de Morais para a Presidência da República, em 1894. E, como na Argentina, a ordem constitucional, conquanto desafiada pelas revoltas militares, como a de 1922 (Rio de Janeiro) e 1924 (Rio Grande do Sul e São Paulo), que deu origem à Coluna Prestes (1924-1926), não sofreu qualquer interrupção até 1930, quando a revolução liderada por Getúlio Vargas, Governador do Rio Grande do Sul, triunfou e destruiu a República Velha". (MONIZ BANDEIRA, Luiz Alberto. O Estado Nacional e Política Internacional na América Latina - O continente nas relações Argentina - Brasil (1930 1992). 2. ed. São Paulo: Ensaio, 1995. p. 22)

${ }^{198}$ Raymundo Faoro ressalta o desencanto com os governantes pelos governados, durante os anos 20, de 1922 a 1930. "Nesse curso de oito anos, alimentado por lenta desintegração, as defesas ideológicas do regime republicano perderam a consistência. As glórias sonhadas pelos propagandistas, as utopias dos extremados, o federalismo dos homens práticos convertem-se, na consciência geral, em instituições odiosas. Alguns elementos se transformam, o federalismo se concentra no presidencialismo forte, o País essencialmente agrícola transige com as indústrias, o liberalismo cede o lugar ao intervencionismo estatal. Estas oscilações, com reformas secundárias, em vez de satisfazer as reivindicações, confirmam o humor cético, acentuam a descrença do sistema, sugerem a reorganização do teatro e a aposentadoria dos atores. Os governados que se agitam perdem a confiança nos dirigentes, preocupados em cimentar as pedras soltas com a violência, quebrando o elo da solidariedade comum." (FAORO, Raymundo. Os Donos do Poder. 10. ed. São Paulo: Globo, 2000, v. II, p. 304). Marcos Wachowicz aduz que, "como exemplo têmse a abusiva intervenção do Presidente da República nos Governos dos Estados-Membros, a corrupção do processo eleitoral, com vícios decorrentes do sistema de voto descoberto, salientando-se que o eleitorado se constituía por $2 \%$ a 3\% da população que, em 1920, era pouco mais de 30 milhões". (WACHOWICZ, Marcos. Poder Constituinte e Transição Constitucional Perspectiva Histórico-Constitucional. Curitiba: Juruá, 2000. p. 110)

${ }^{199}$ Adriano Campanhole e Hilton Campanhole expõem o art. $6^{\circ}$, da Emenda Constitucional de 3 de setembro de 1926, a seguinte redação: "Art. $6^{\circ}$. O Governo Federal não poderá intervir em negócios peculiares aos Estados salvo: I) Para repelir invasão estrangeira, ou de um Estado em outro; II) Para assegurar a integridade nacional e o respeito aos seguintes princípios constitucionais: a) forma republicana; b) o regime representativo; c) o governo presidencial; d) a independência e harmonia dos poderes; e) a temporariedade das funções eletivas e a responsabilidade dos funcionários; f) a autonomia dos municípios; g) a capacidade para ser eleitor ou elegível nos termos da Constituição; h) um regime eleitoral que permita a representação das minorias; i) a inamovibilidade e vitaliciedade dos magistrados e a irredutibilidade dos seus vencimentos; j) os direitos políticos e individuais assegurados pela Constituição; $k$ ) a não reeleição dos Presidentes e Governadores; I) a possibilidade de reforma constitucional e a competência do Poder Legislativo para decretá-la. III) Para garantir o livre exercício de qualquer dos poderes públicos estaduais, por solicitação de seus legítimos representantes, e para, independente de solicitação, respeitada a existência dos mesmo, por termo à guerra civil. IV) Para assegurar a execução das leis e sentenças federais e reorganizar as finanças do Estado, cuja incapacidade 
autocrático do País pelo Presidente Federal em três direções: enfraquecendo a

autonomia dos Estados; facilitando a aplicação do veto presidencial; e impondo ainda maiores restrições à liberdade do cidadão".

Com a Reforma Constitucional ${ }^{201}$ e estando no poder o Presidente Arthur

Bernardes, este governaria sob estado de sítio, enfrentando uma série de rebeliões.

O estado de sítio, a intervenção federal, além do recrudescimento da repressão

policial são as características do quatriênio bernardista, mas não exclusiva desse

quatriênio ${ }^{202}$.

para a vida autônoma se demonstrar pela cessação de pagamento de sua dívida fundada, por mais de dois anos. $\S \mathbf{1}^{\circ}$ Compete privativamente ao Congresso Nacional decretar a intervenção nos Estados para assegurar o respeito aos princípios constitucionais da União (II); para decidir da legitimidade dos poderes, em caso de duplicata (III), e para reorganizar as finanças do Estado insolvente ( $\left.n^{\circ} \mathrm{IV}\right)$. $\$ \mathbf{2}^{\circ}$ Compete privativamente ao Presidente da República intervir nos Estados, quando o Congresso decretar a intervenção $\left(\S 1^{\circ}\right)$; quando o supremo Tribunal a requisitar $\left(\S 3^{\circ}\right)$; quando qualquer dos poderes públicos estaduais a solicitar (III); e, independentemente de provocação, nos demais casos compreendidos neste artigo". (CAMPANHOLE, Adriano; CAMPANHOLE, Hilton. Todas as Constituições do Brasil. São Paulo: Atlas, 1971, p. 458)

${ }^{200}$ HAMBLOCH, Ernest. Ob. cit., p. 85.

${ }^{201}$ BELLO, José Maria. Ob. cit., p. 257. Também Franco Afonso Arinos de Melo e Jânio Quadros (ob. cit., p. 292) salientam que o Presidente Bernardes, quando se julgou suficientemente forte pelo apoio da maioria parlamentar e das máquinas dos governos estaduais, promoveu no Congresso Nacional a reforma da Constituição de 1891, como já tentara sem êxito o Presidente Epitácio Pessoa. Foi proibido o que se chamava na gíria parlamentar "cauda orçamentária", isto é, a faculdade de legislar sobre as mais extravagantes matérias nas leis de meios, velha fonte de grandes abusos; limitou-se também a extensão do habeas corpus, que se convertera em instrumento político; instituiu-se a faculdade de vetos parciais do Presidente da República e regulou-se a expulsão de estrangeiros perigosos. Em suma, a reforma constitucional visava, sobretudo, reforçar a autoridade da União, ou, mais especialmente, do seu Poder Executivo.

${ }^{202}$ Ernest Hambloch (ob. cit., p. 101-102), em uma análise dos estados de sítio onde se dá poder discricionário ao executivo, apresenta uma cronologia peculiar: "O Marechal Deodoro da Fonseca exerceu poderes discricionários desde a declaração da República em 1889 até a promulgação da Constituição de 1891, a saber, por 467 dias. Durante os 271 dias do seu período como primeiro Presidente Constitucional houve um estado de sítio de 20 dias. Ele renunciou e foi sucedido pelo Vice-Presidente, o Marechal Floriano Peixoto, em cujo período de governo de pouco mais de dois anos e meio o país esteve em estado de sítio por mais de nove meses. Prudente de Morais (18941898), estado de sítio superior a três meses. Campos Sales (1898-1902), não houve estado de sítio devido à 'política dos governadores'. Rodrigues Alves (1902-06), estado de sítio superior a três meses. Marechal Hermes da Fonseca (1910-14), estado de sítio durante nove meses. Wenceslau Braz (1914-18), estado de sítio superior a doze meses. Epitácio Pessoa (1919-22), estado de sítio durante quatro meses. Arthur Bernardes, estado de sítio durante quase dois anos, com vários intervalos. Washington Luís (1926-30), estado de sítio superior a dois meses. Júlio Prestes, não empossado devido ao movimento revolucionário de outubro de 1930 , que colocou Getúlio Vargas na Presidência com 'poderes discricionários'”. José Antônio Giusti Tavares (ob. cit., p. 175) discorre que o Presidente Campos Sales "concebeu a fórmula política sobre a qual repousaria durante três décadas, o grande pacto oligárquico da Primeira República. Esta fórmula política, viabilizada através da instituição do federalismo, pela política dos governadores compreendia: 'a) uma hierarquização, segundo o nível de desenvolvimento econômico e a 
Arthur Bernardes, mineiro, é sucedido por Washington Luís, paulista. Nesta época, lembra Giusti Tavares, "que a partir dos anos 20, a decadência da cafeicultura mineira teve como resultado o monopólio, por São Paulo, da condição de oligarquia central, e a conversão da oligarquia mineira em oligarquia secundária" ${ }^{203}$.

Estes fatos, assomado a outros, como a disputa do partido democrático paulista com o partido republicano paulista e deste com o partido republicano mineiro ${ }^{204}$ vão influir poderosamente na sucessão de Washington Luís. Washington Luís indica um paulista para sucedê-lo, quebrando a política café com leite, alijando Minas da sucessão ${ }^{205}$.

A oposição ${ }^{206}$ reunira-se em torno de Getúlio Vargas, governador do Rio Grande do Sul e ex-ministro do governo de Washington Luís. O governo não perdia a eleição, e aqui novamente não se fez exceção. Júlio Prestes é eleito.

envergadura eleitoral de cada estado, das oligarquias regionais; e no quadro desta hierarquia, b) o reconhecimento, pelas 'oligarquias periféricas', da hegemonia do eixo São Paulo- Minas Gerais e, ancilar e excepcionalmente, pela oligarquia gaúcha, do controle sobre o Estado nacional, afeiçoando-Ihe as políticas públicas e elegendo-lhe o presidente; ao mesmo tempo em que c) o presidente e aqueles dois estados reconheciam a autonomia das oligarquias periféricas".

${ }^{203}$ HAMBLOCH, Ernest. Ob. cit., p. 175.

${ }^{204}$ LOVE, Joseph. A Revolução de 30 e o Regionalismo Gaúcho, conferência proferida no Simpósio sobre a Revolução de 30, realizada em 1980 pela UFRS, publicada pela ed. Erus, 1983, p. 65.

205 Discorre José Antônio Giusti Tavares (ob. cit., p. 176) que "violada, com a candidatura de Júlio Prestes, a fórmula política oligárquica que estabelecia a alternância entre São Paulo e Minas no exercício da presidência, instalou-se o conflito no interior do núcleo oligárquico hegemônico, empurrando Minas para a dissidência política. Ao mesmo tempo, fora desrespeitada a posição ancilar que, no pacto de dominação, e frente a qualquer desentendimento entre os dois estados acerca da alternância presidencial, a fórmula política oligárquica atribuíra ao Rio Grande do Sul, de modo que também este ingressou na dissidência".

${ }^{206}$ Ricardo Seitenfus observa que "a singularidade da campanha eleitoral da Aliança Liberal não se resume unicamente à improvisação, às hesitações e ao desconhecimento das implicações da crise econômica mundial sobre a economia do País. Mais espantosa ainda é a conclusão de um gentlemen's agreement entre Getúlio Vargas e Washington Luís", na qual, dentre outros pontos, Getúlio Vargas compromete-se "em não sair do Estado do Rio Grande do Sul para fazer propaganda eleitoral". (SEITENFUS, Ricardo. O Brasil de Getúlio Vargas e a Formação dos Blocos 1930-1942. São Paulo: Nacional, 1985. p. 19) 
Aqui, diferente de outras ocasiões, o mundo atravessa uma crise, a de 1929, com a quebra da bolsa em Nova Iorque, e a política econômica de Washington Luís relativamente ao café, maior produto de exportação do Brasil, provoca uma quebra entre o governo nacional e as lideranças paulistas ${ }^{207}$ e, pela primeira vez, desde a proclamação da República, uma revolução tem chance de vitória.

E a três de outubro de 1930, inicia-se o movimento ${ }^{208}$ e, a vinte e quatro de outubro, o Exército deu um golpe depondo Washington Luís, instalando em seu lugar uma junta militar ${ }^{209}$ que entrega, a três de novembro, o governo, a Getúlio Vargas que investiu-se no posto de Chefe do Governo Provisório.

Getúlio, em onze de novembro, suspende a Constituição, nomeia interventores em todos os Estados, exceto em Minas Gerais ${ }^{210}$.

Caíra a República Velha ${ }^{211}$ e o Brasil tinha seu primeiro ditador ${ }^{212}$ desde 0 Marechal Floriano Peixoto; em outras palavras, "Getúlio Vargas destruiu a ordem constitucional implantada após a proclamação da República, em 1889, e cuja

${ }^{207}$ Acrescido do fato de Washington Luís ter resolvido cassar, por vício de forma, todos os mandatos dos deputados eleitos pela Aliança da Paraíba e alguns de Minas Gerais. (Ricardo SEITENFUS. $\mathbf{O}$ Brasil de Getúlio Vargas, p. 22). O estopim é o assassinato de João Pessoa.

208 Inicialmente no Rio Grande do Sul, depois na Paraíba e em Minas Gerais.

${ }^{209}$ Esta junta era composta pelos generais Augusto Tasso Fragoso, João de Deus, Menna Barreto e o contra-almirante Isaías de Noronha.

${ }^{210}$ Raymundo Faoro (ob. cit., p. 313) sustenta que "a ótica dos homens que ocupam o Catete, a 3 de novembro de 1930, será adversa ao esquema da política dos governadores, mas se compreende dentro de suas coordenadas mentais. Vencedora a revolução, empreendidas as reformas políticas e só políticas, com o voto secreto e a supervisão judicial, outra vez São Paulo, com outros homens talvez, e Minas Gerais, com os mesmos líderes, comandariam a República renovada". Com o que, obviamente, o Rio Grande do Sul não concordará.

${ }^{211}$ Moniz Bandeira (ob. cit., p. 22) argüí que, "durante o período de 1880-1930, o poder civil, sob controle de oligarquias agro-exportadoras, predominou e manteve a moldura democráticorepresentativa tanto na Argentina quanto no Brasil (salvo os quatro anos subseqüentes à proclamação da República). Porém, a profunda crise do sistema capitalista, que o colapso da bolsa de Nova lorque, em 1929, refletiu e propagou, estremeceu praticamente todos os países da América Latina, onde, nos anos subseqüentes, fortes abalos políticos se seguiram e se encadearam, com golpes de Estado e revoluções a reajustarem as estruturas de poder".

212 Pelo Decreto 19.389, de 11.11.1930, em seu art. $1^{\circ}$, dispunha que "O Governo Provisório exercerá discricionadamente em toda a sua plenitude, as funções e atribuições, não só do Poder Executivo como do Poder Legislativo, até que eleita a Assembléia Constituinte, estabeleça esta a 
estabilidade a restauração do poder civil, em 1894, assegurara por quase 40

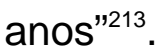

Gerson Moura sustenta que "as mudanças políticas produzidas pela Revolução de 30 no Brasil ocorreram em meio à depressão econômica generalizada nas sociedades capitalistas ocidentais e à crise dos seus modelos e valores políticos e ideológicos"214.

A era Vargas pode ser delimitada por vários episódios, a começar pela Revolução Constitucionalista de $1932^{215}$, em São Paulo, pela Constituição de 1934, pelo golpe do Estado Novo, em 1937, pelas restauração democrática, de 1945, pela Constituição de 1946, pelo segundo Governo de Vargas, de 1950, até sua morte em 1954 e a era pós-Vargas, até $1964^{216}$.

reorganização constitucional do País".

${ }^{213}$ MONIZ BANDEIRA, , Luiz Alberto. Ob. cit., p. 22.

${ }^{214}$ MOURA, Gerson. A Revolução de 1930 e a Política Externa Brasileira: Ruptura ou Continuidade?, artigo publicado na obra A Revolução de 30 - Seminário Internacional. Brasília: UnB, 1982. p. 578.

${ }^{215}$ Hélio Silva coloca como suas raízes as seguintes razões: "São Paulo e o tradicional Partido Republicano Paulista (Partido de Representação Popular), tinham sustentado a candidatura da Júlio Prestes de Albuquerque. Uma dissidência política ponderável, constituída do Partido Democrático, combatera aquela candidatura e questionara o seu resultado. Participara da conspiração, embora os democráticos não tivessem trazido contribuição combatente. Assim, quando Vargas se negou a entregar o Estado aos democratas, armou as bases para uma frente única que uniria as agremiações políticas e arrastaria a população paulista, a qual se sentia humilhada com a ocupação militar e a direção dos negócios públicos entregues a forasteiros". (SILVA, Hélio. O Primeiro Século da República. Rio de Janeiro: Jorge Zahar, 1987. p. 78)

${ }^{216}$ Octavio lanni (ob. cit., p. 77-78) discorre que "No Brasil o varguismo teve várias fases. Entre 1930 e 1937, Getúlio Vargas ensaiou uma democracia de bases populares, fazendo concessões simultâneas à classe média e ao proletariado. Nesses anos, criou algumas bases do populismo brasileiro, formulando a doutrina da 'paz social' e reconhecendo os sindicatos como legítimos órgãos do proletariado. Nos anos de 1937-1945, Vargas instalou uma ditadura de tipo populista, sob a denominação de Estado Novo, com elementos de inspiração corporativa. Nesse período, outorgou a Consolidação das Leis do Trabalho (CLT), formalizando as relações de trabalho nos setores secundário e terciário. Por meio do salário mínimo, as férias remuneradas, o aviso-prévio, a proteção à maternidade e outros dispositivos formalizaram-se os direitos e os deveres dos trabalhadores no mercado de trabalho industrial tanto quanto nas outras atividades produtivas localizadas na cidade. Ao mesmo tempo, criam-se os requisitos organizatórios ou burocráticos por meio dos quais se dá o aparecimento do peleguismo. O pelego passa a ser um elemento essencial da burocracia sindical populista, pois aparece em muitas situações importantes, vinculando trabalhadores e sindicatos ao aparelho estatal. Nos anos 1951-1954, o populismo de Vargas conformou-se às regras da democracia representativa, onde os remanescentes da oligarquia, ao lado do imperialismo, estiveram bastante ativos contra o seu governo. Talvez os dois mais importantes acontecimentos do governo populista, nesse período, tenham sido a criação 
Na Revolução Constitucionalista, São Paulo é derrotado e seus chefes

presos e deportados para Portugal e Argentina. Vargas procura compor-se com São

Paulo, mas o seu sacrifício assegurara a convocação da Assembléia Nacional

Constituinte $^{217}$ e eleições que se realizaram a 3 de maio de 1933.

Se a Constituinte ${ }^{218}$ se instalou em ambiente de grandeza, a Constituição

não agradou a uns e a outros ${ }^{219}$. A Constituição de 1934, seria suspensa em 1935 ,

pela decretação do estado de sítio e, em $1937^{220}$, seria revogada por uma

Constituição corporativista.

da Petróleo Brasileiro S.A. (Petrobrás) e a publicação da Carta Testamento, de Vargas. Nessa carta, escrita às vésperas do seu suicídio, ocorrido em 24 de agosto de 1954, Vargas resume alguns dos principais pontos do populismo brasileiro. A idéia de devolver o País ao povo, de que o imperialismo impedia o progresso nacional, inclusive porque estava associado a grupos econômicos nacionais, está presente na carta, e alimentará boa parte da ideologia populista até a deposição do governo Goulart, em 1964. Aliás, a democracia populista alcança os seus desenvolvimentos extremos e entra em colapso nos anos 1961-1964, nesse governo. Ao longo dos anos cinqüenta e sessenta, um elemento importante do populismo foi a aliança entre o Partido Social Democrático (PSD), o Partido Trabalhista Brasileiro (PTB)... Essa aliança elaborou e desenvolveu as relações entre o proletariado, as organizações sindicais e o aparelho estatal".

${ }^{217}$ Para Marcos Wachowicz (ob. cit., p. 112) a "Revolução que levou Getúlio Vargas ao Poder pretendia transformar o caráter provisório do governo em definitivo, faltando-lhe, porém um programa de ação global. Essa falta de planejamento, editando leis retroativas, começara a enfraquecer o próprio regime, instaurado sem plano de ação, acarretando instabilidade política".

${ }^{218}$ Manoel Correia de Andrade aduz "que a Constituinte, eleita em maio de 1933, era composta por políticos do período pré-revolucionário, por políticos e tenentes emergidos da revolução, eleitos pelo povo, e por deputados classistas eleitos pelos sindicatos de patrões e empregados. Tratavase de uma concessão às idéias então em voga na Europa. Queria-se demonstrar com isto a falência da Democracia Liberal e sua substituição pela Democracia Social". (ANDRADE, Manoel Correia de. A Revolução de 30 - Da República Velha ao Estado Novo. Porto Alegre: Mercado Aberto, 1988, p. 74)

${ }^{219}$ Hélio Silva (O Primeiro Século da República, p. 81) discorre que "o choque entre conservadores e renovadores refletiu-se nos desacertos dos muitos pontos debatidos. A Liga Eleitoral Católica, com apoio maciço da bancada paulista, conseguiu a aprovação de suas emendas. Getúlio Vargas teve o seu mandato constitucional assegurado. A troco, os interventores também puderam fazerse eleger governadores constitucionais nas assembléias estaduais que se reuniram em seguida. Como muitos interventores não tinham base eleitoral, esses que se intitulavam portadores do espírito revolucionário, entravam em conluio com os antigos políticos derrotados em 30 , elegendose com o seu apoio. Daí episódios lamentáveis, como o seqüestro de deputados, a compra de votos e atentados em pleno recinto parlamentar".

${ }^{220}$ Hélio Silva (idem, p. 82) sustenta que "Todos os golpes se parecem. Políticos agitam a opinião pública, estimulam os militares e estes intervêm, sob a alegação de que defendem as instituições constitucionais. Em 1937, perdurava o clima da Revolta Vermelha de 1935, sufocada sucessivamente em Natal, Recife e Rio de Janeiro. Os comunistas estavam presos. Mas os generais, reunidos no gabinete do ministro da Guerra, a 27 de setembro, deliberam agir, mesmo se colocando acima da Constituição. Vargas concordou com o golpe, que the assegurava a permanência no poder, afastando as duas candidaturas apresentadas à sua sucessão: Armando de Sales Oliveira e José Américo de Almeida, além de Plínio Salgado. Olímpio Mourão Filho 
Com a implantação do Estado Novo ${ }^{221}$, dissolvem-se o Senado e a Câmara, acabam-se os partidos políticos de toda a ordem ${ }^{222}$ e o Presidente da República

ganha poderes absolutos, ad referendum de um plebiscito que nunca se realizou. Hélio Silva ${ }^{223}$ relata que "a imprensa silenciou, sob censura e a ação política transformou-se em ação conspiratória".

A Constituição de 1937, elaborada pelo jurista Francisco de Campos, absorveu vários princípios defendidos pelo integralismo 224 . O mandato presidencial

apresenta o Plano Cohen, denunciando uma (falsa) preparação de um movimento comunista e a 10 de novembro de 1937, era criado o Estado Novo".

${ }^{221}$ Raymundo Faoro (ob. cit., p. 323), citando Góes Monteiro, ministro da Guerra de Getúlio, discorre que "o Estado deve ter o poder para intervir e regular toda a vida coletiva e disciplinar a nação, criando os órgãos e aparelhos próprios para organizar a nossa economia, obrigar todos ao trabalho e satisfazer o mínimo das necessidades morais e materiais de todo o cidadão brasileiro que sirva, realmente, à sua pátria. Onde estaria o apoio para essa empresa? Na opinião pública sem caráter nacional, nos estadualismos exclusivistas, nas ambições pessoais arvoradas em lideranças, nos partidos artificiais, no fascismo, nazismo ou bolchevismo? A resposta é concludente! Ficam só o Exército e a Marinha como instituições nacionais e únicas forças com esse caráter, e só à sombra delas é que, segundo a nossa capacidade de organização, poderão organizar-se as demais forças da nacionalidade. Nestas condições, as forças militares nacionais têm que ser, naturalmente, forças construtoras, apoiando governos fortes, capazes de movimentar e dar nova estrutura à existência nacional, porque só com a força se pode construir, visto que com a fraqueza só se constroem lágrimas".

222 Inclusive a Aliança Nacional Libertadora, de orientação fascista, de Plínio Salgado, que transformou-se em um grêmio cultural. Manoel Correia de Andrade (ob. cit., p. 77-78) sintetiza o pensamento integralista, que em alguns aspectos influenciou a Constituição de 37. São eles: "1. A nação é um organismo político, econômico e étnico e, portanto, a representação não pode ser exclusivamente política; 2. o sindicato deve ser pessoa de direito público; 3 . a economia deve ser dirigida pelo Estado; 4. deve-se dar uma função social à técnica capitalista e à propriedade; e a estas agregaram-se 5. deve haver unidade da federação; 6 . a representação política de caráter técnico, devendo existir ao lado da representação econômica, mas como expressões de forças produtoras e culturais das diferentes regiões; 7 . autonomia administrativa dos municípios; 8. integração dos grupos profissionais no Estado de baixo para cima; 9. exclusão de toda tirania exercida pelo Estado contra o indivíduo e suas projeções morais".

${ }^{223}$ SILVA, Hélio. Ob. cit., p. 82.

${ }^{224} \mathrm{Em}$ contraponto aos integralistas, havia o programa político da Aliança Nacional Libertadora. Segundo Manoel Correia de Andrade (ob. cit., p. 80), o programa político da Aliança se alicerçava nos seguintes princípios: "I - Suspensão definitiva do pagamento das dívidas imperialistas do Brasil, por se considerarem já pagas, e aplicação da quantia assim retida em benefício do povo explorado do Brasil, por se considerarem já pagas, e aplicação da quantia assim retida em benefício do povo explorado do Brasil; II - nacionalização imediata de todas as empresas imperialistas, por as considerarmos arapucas para os quais os brasileiros trabalham como cães, enquanto os seus lucros vão para os bolsos de alguns magnatas estrangeiros; III - proteção aos pequenos e médios proprietários e lavradores; entrega das terras dos grandes proprietários aos camponeses e trabalhadores rurais que as cultivam, por considerar terem sido eles os que as valorizaram com o seu trabalho e, portanto, são seus únicos e legítimos proprietários; IV - gozo das mais amplas liberdades populares pelo povo brasileiro, nele incluídos os estrangeiros que aqui trabalham e são explorados como os próprios brasileiros. Estas liberdades foram conquistadas pelo povo que nunca as gozou, de fato, em toda a sua plenitude. Hoje, ele as reclama, e é legítimo 
passava a ser de seis anos, e o ditador poderia legislar através de decretos-lei, ou seja, o Presidente passou a ter uma série de funções legislativas que fortaleciam grandemente o Executivo. Vargas criou um Departamento de Imprensa e Propaganda, que passou a realizar censura à imprensa a fim de que não se propagassem as idéias democráticas e de que se criasse uma atmosfera de apoio ao Estado forte ou nacional.

A última resistência armada ao Estado $\operatorname{Novo}^{225}$ e a Vargas foi a 11 de maio de 1938 , feita pelos integralistas, sem sucesso ${ }^{226}$.

No âmbito da política externa, Vargas se caracteriza por uma ambigüidade estratégica e peculiar ${ }^{227}$.

o direito que tem de ser satisfeito custe o que custar; $\vee$ - constituição de um governo popular, orientado somente pelos interesses do povo brasileiro e do qual poderá participar qualquer pessoa na medida da eficiência de qualquer colaboração".

${ }^{225}$ Ricardo Seitenfus (O Brasil de Getúlio Vargas, p. 174 e ss.) chama atenção da desconfortável posição principalmente do fascismo italiano depois da implantação do Estado Novo e da não participação, no governo, dos integralistas, mas, por outro lado, ressalta o convite formulado pela Alemanha e Itália para o Brasil aderir ao Pacto anti-Komintern, o que foi recusado.

${ }^{226}$ Ricardo Seitenfus (O Brasil de Getúlio Vargas, p. 197) sustenta que "o fracasso de 11 de maio concede ao Estado Novo uma certa legitimidade. Doravante, não se poderá mais fazer o paralelo entre integralismo e Estado Novo; Vargas dessa vez provou, sem recorrer à falsificação de documentos, como no caso de plano Cohen, que o extremismo espreita o país".

${ }^{227}$ Gerson Moura (ob. cit., p. 582-583) comenta que Também aqui a política externa se pautou pela eqüidistância, já que no plano externo persistiu até o final da década um empate na disputa entre os sistemas de poder emergentes e no pleno interno uma forte divisão político ideológica perpassava a sociedade e o Estado brasileiros.

As lutas políticas da década de 30 , que caminharam na direção de um fechamento do regime liberal democrático, apontavam para uma identificação do Estado brasileiro às experiências fascistas européias a partir do Estado Novo (1937), especialmente por seu repúdio ao liberalismo político e econômico e sua ênfase nas soluções nacionalistas e corporativistas. A observação mais cuidadosa aponta porém para certas especificidades do Estado Novo, ligadas a características da sociedade brasileira. O regime era centralizador mas não deixava de compor-se com as oligarquias estaduais. Dependia em boa medida do Exército, mas não era uma ditadura militar. Era tendencialmente industrialista, mas não havia um projeto industrializante claro. Essas ambigüidades derivam do fato de que a ação estatal incorporava novos atores sociais sem desalojar necessariamente os antigos. Além disso, a polarização política recortava os vários grupos de interesse, os organismos técnicos do Estado, a burocracia militar, a diplomacia e até mesmo as instâncias centrais de decisão, colocando, de um lado, os defensores do comércio compensado e do protecionismo, os nacionalistas e os pró-Alemanha e, de outro lado, os advogados do livre-comércio, da liberdade cambial e tarifária, os pan-americanistas e os próEstados Unidos. O processo político no Estado Novo refletia esse empate da luta política, o que conferia a Vargas um extraordinário poder no processo decisório. Ele se tornou o árbitro das disputas que emanavam das instâncias secundárias e mesmo das que ocorriam nas instâncias centrais de decisão. Dois grandes problemas internos, com reflexos inevitáveis sobre as relações 
A eclosão da Segunda Guerra Mundial modificou a relação até então

\author{
mantida entre o Brasil e a Alemanha ${ }^{228}$ e os EUA E $^{229}$.
}

exteriores do Brasil, assoberbavam o governo Vargas, especialmente a partir do golpe de 1937: o reequipamento das forças armadas e o reequipamento econômico do País, em especial a questão da grande siderurgia. Também nesses problemas, a política externa se caracterizou até o final da década por uma eqüidistância pragmática. [...] Foi também a eqüidistância pragmática que criou as condições políticas para o sucesso dos esforços em torno da criação da grande siderurgia.

${ }^{228}$ Edgard Carone relata que "a Alemanha, a pretexto das pesadas indenizações do Tratado de Versalhes, da falta de cambiais para negociar normalmente, da crise existente depois de 1929, os nazistas insistem num comércio de trocas e não de compras. Aproveitando-se dos grandes estoques não vendáveis existentes entre os países produtores, a Alemanha propõe o sistema de 'marco compensado', isto é, um acordo bilateral, em que cada país estipula o que vai vender e o preço da respectiva mercadoria: 'o Askimark' difere da moeda bloqueada comum disponível para certos fins para quem queira, em que está à disposição do exportador só para a compra de determinadas mercadorias na Alemanha. A Alemanha podia pagar bons preços em Askimarks, compensando esta generosidade mediante o aumento do preço dos artigos que se pagavam com estas divisas. Na realidade, a Alemanha comprava comumente excedentes latino-americanos, os pagava com Askimarks, e depois vendia essas mercadorias em desesperada competição com os produtores originais... Depois de constituir-se em principal mercado de certos produtos, a Alemanha estava em condições de exercer pressão comercial, para forçar a América Latina a comprar uma extensa variedade de mercadorias". (CARONE, Edgard. O Estado Novo (19371945). Rio de Janeiro: Difel, 1976. p. 92-93). Ricardo Seitenfus (O Brasil de Getúlio Vargas, p. 77-78) expõe que a "denominação aski deriva de Auslander Soderkonto fur Inlandszahlungen o que significa conta especial do estrangeiro para pagamentos internos". SEITENFUS sintetiza o "Plano Schacht" (presidente do Reichsbank e ministro da economia) adotado pela Alemanha Nazista, sustentando que Berlim objetivava o total controle do Estado sobre o comércio exterior através de medidas como "a obrigação para os importadores alemães de obter um certificado de divisas para poder comprar no estrangeiro, e os contratos-clering (que são acordos comerciais entre dois países nos quais um pelo menos pratica um controle de câmbio estrito), além do sistema compensatório, com os marcos aski". Seitenfus ainda ressalta que a esta época "toda a importação alemã implica, portanto, uma exportação de igual valor. O mais grave nesse sistema é que a compensação importação-exportação buscada pela Alemanha não se faz globalmente, mas país por país".

${ }^{229}$ Gerson Moura (ob. cit., p. 585) sustenta que, no caso dos EUA, "as iniciativas político-ideológicas se corporificaram em programas multilaterais e bilaterais de difusão dos 'ideais pan-americanos' e da retomada vigorosa das Conferências Pan-Americanas em torno de um objetivo comum: a defesa hemisférica. Os 'ideais pan-americanos' constituíam uma resposta à ideologia nacionalsocialista, cujas críticas ao liberalismo, capacidade de mobilização das massas e promessa de uma nova ordem the permitira obter grande penetração nas sociedades latino americanas. O panamericanismo apelava para a adesão aos ideais republicanos, a lealdade, a democracia como um ideal, a reverência pela liberdade, a aceitação da dignidade do indivíduo e seus direitos pessoais invioláveis, a crença na resolução pacífica das disputas, na soberania dos estados e a justiça sob uma lei internacional. Embora esses valores não correspondessem à prática política interna de muitas nações latino-americanas, apresentavam certas vantagens sobre as expressões ideológicas nacional-socialistas. Enquanto estas últimas se corporificavam em um partido político organizado dentro das nações americanas, isto é, traduziam de forma visível a presença da grande potência estrangeira, o pan-americanismo sublinhava o respeito à soberania nacional e a solidariedade entre as nações. Nesse sentido, o pan-americanismo cumpria à perfeição o papel mediador de ideologia política entre o centro hegemônico e seus aliados potenciais, na medida que transmutava a hegemonia norte-americana em solidariedade e cooperação continentais e permitia à dominação política aparecer como respeito à soberania nacional das repúblicas latinoamericana". 
O Brasil alia-se aos Estados Unidos e, em 1942, rompe relações diplomáticas com o Eixo. No mesmo ano declara guerra ao Eixo ${ }^{230}$, enviando para a Europa a Força Expedicionária Brasileira (FEB).

A volta dos soldados ao Brasil causa entusiasmo popular e acelera as pressões pela democratização. Vargas renuncia em outubro de $1945^{231}$, e o general Eurico Gaspar Dutra, ex-ministro da Guerra de Vargas, vence as eleições e toma posse em janeiro de 1946.

Em setembro de 1946, é promulgada uma nova Constituição, de caráter mais democrático. Nas eleições de 1950, Vargas é eleito presidente. Suicida-se em 1954, e é sucedido por Café Filho. Em 1955, Juscelino Kubitschek é eleito presidente, inaugurando Brasília, a nova capital do País. Juscelino é sucedido por Jânio Quadros, que, ainda em 1961, renuncia. Toma posse seu vice, João Goulart, eleito sob a égide presidencialista, mas, para assumir, é obrigado a aceitar o regime

${ }^{230}$ Gerson Moura (ob. cit., p. 589) relata ainda que "é certo que a declaração de guerra não resultou de uma pressão dos aliados, antes nasceu da conjuntura política interna. Ao contrário, os aliados tinham boas razões para não desejar que o Brasil entrasse na guerra: o País já estava fazendo tudo o que os aliados the haviam designado em seus planos estratégicos. além disso, a participação efetiva na guerra criaria demandas adicionais (equipamento, assistência técnica, transporte, logística etc.) sobre os aliados, demandas que estes não gostariam de suprir. Por outro lado, haveria certas vantagens na declaração de guerra: ela asseguraria uma lealdade mais clara dos chefes militares brasileiros à causa aliada, assim como uma luta mais decidida contra a quinta-coluna: exerceria alguma influência sobre a posição de Portugal no conflito, assim como a da Argentina e do Chile, que ainda não tinham rompido relações diplomáticas com o Eixo. entre as vantagens e desvantagens da decisão, o governo americano reagiu discretamente, enquanto nos círculos diplomáticos britânicos o desgosto foi evidente".

${ }^{231}$ Moniz Bandeira (Estado Nacional e Política Internacional na América Latina, p. 56) sustenta que "o golpe militar de 29 de outubro de 1945 não visou a assegurar a restauração da democracia política, àquele tempo já em curso, e sim a evitar sua ampliação social, devido à crescente participação da massa trabalhadora no movimento 'queremista' (Queremos Getúlio), promovido por líderes sindicais, trabalhistas e comunistas, em favor da Constituinte com Vargas. Seu objetivo, portanto, não foi defender e sim impedir a mudança qualitativa do status quo vigente no Estado Novo. O poder de fato e, depois, de direito, continuou em mãos das Forças Armadas, mais exatamente, dos mesmos generais, como Eurico Dutra e Goes Monteiro, que implantaram, sustentaram e acabaram, quando Ihes foi conveniente, a chamada ditadura de Vargas. 
parlamentarista ${ }^{232}$. Goulart governa até $1964^{233}$, quando é deposto pelas forças

${ }^{232}$ A este respeito, são necessárias algumas considerações. O Ato Adicional, como passou a ser chamada a Emenda Constitucional 4, de 02.09.1961, foi aprovada por 288 deputados e 47 senadores contra 55 e 6, respectivamente. Em todas as Constituições republicanas, notadamente de 1934 e 1946, sob a liderança de Raul Pilla (Deputado federal por várias legislaturas, incansável defensor do parlamentarismo. O Congresso Nacional homenageou-o, com a publicação de PILLA, Raul. Perfis Parlamentares, n. 16, Brasília, Câmara dos Deputados, 1980), o ideal parlamentarista esteve em pauta, embora rejeitado pela maioria sob o fundamento de que o povo brasileiro não atingira o estágio político-cultural propício a este sistema de governo. Novamente em 1949, em 1952, em 1956 e, finalmente, pouco antes da renúncia de Jânio Quadros, a 6 de julho de 1961, Raul Pilla apresentou sua proposta de reforma na tentativa de introduzir o governo de Gabinete. Nessa época, muitas opiniões anteriormente contrárias ao parlamentarismo convenceram-se da inviabilidade do sistema presidencial no Brasil e voltaram suas esperanças para os sistema que assegurara anos de paz no Império. Com a renúncia de Jânio Quadros, constitucionalmente João Goulart assumiria a Presidência; este, no entanto se fazia indesejável a muitos setores influentes no sistema do poder, mormente aos ministros militares, representando as forças armadas. Nesta altura dos acontecimentos, convém perguntar-se: Por que o sistema parlamentar se estabeleceu no Império, apesar da Carta de 1824 e assim não se sucedeu na República velha? Olímpio Ferraz de Carvalho nos dá a seguinte resposta: "Não se estabeleceu na República velha porque a Constituição de 1891 trancou todas as portas para aquele sistema: erigiu em norma de governo a irresponsabilidade ministerial, proibiu, como se fosse um crime, o comparecimento dos Ministros no Congresso, separou completamente o Poder Executivo do Legislativo, a ponto de não estabelecer entre eles senão comunicação escrita. A Carta do Império não fazia tão rigorosa e absoluta separação, como se os dois poderes não se pudessem avistar. Ela permitia aos senadores e deputados serem nomeados para o cargo de Ministro de Estado ou Conselheiro, sendo que os senadores continuavam a ter assento no Senado e os deputados deixavam vagos os seus lugares na Câmara e procedia-se a novas eleições nas quais podiam ser reeleitos e acumular as duas funções". (CARVALHO, Olímpio Ferraz de. Sistema parlamentar: história constitucional e política. São Paulo: Piratininga, 1933, p. 174). Os principais pontos do Ato Adicional podiam, assim, ser sintetizados: O seu art. $1^{\circ}$ definia, em essência, o sistema, ao declarar que o Poder Executivo seria exercido pelo Presidente da República e pelo Conselho de Ministros, cabendo a este a direção e a responsabilidade da política do governo, assim como da administração federal. O Presidente seria eleito pelo Congresso Nacional por maioria absoluta de votos e exerceria o cargo por cinco anos. O Conselho de Ministros respondia coletivamente perante a Câmara de Deputados, pela política do Governo e pela administração federal. Seus membros eram nomeados pelo Presidente da República, porém, por indicação do Presidente do Conselho. O Presidente do Conselho, ou Primeiro Ministro, seria indicado pelo Presidente da República à Câmara, que aprovaria ou não a indicação. Só depois de ter aprovado o seu nome, o Primeiro Ministro formaria o gabinete, com o qual se apresentaria à Câmara para dar-lhe a conhecer o programa do governo. Analisando-se o Ato Adicional, observa-se que os atos do Poder Executivo somente teriam validade se referendados pelo Presidente do Conselho (art. $7^{\circ}$ ) e 0 Conselho de Ministros era responsável perante a Câmara de Deputados pela política do Governo (art. $6^{\circ}$ ). O comando supremo das forças armadas, (art. $3^{\circ}, \mathrm{X}$ ), era exercido pelo Presidente do Conselho de Ministros. O Presidente do Conselho de Ministros, além da direção geral do Governo, tinha funções específicas: cabia-Ihe a iniciativa dos projetos de governo, a direção da política externa, o exercício do poder regulamentar, a decretação do estado de sítio, a decretação e execução da intervenção nos Estados, a remessa da proposta orçamentária e a prestação das contas do Governo. Pelo parlamentarismo clássico, qualquer derrota do gabinete na Câmara pode ser transformada em questão de confiança, com as duas clássicas saídas, ou haverá a mudança de gabinete ou a dissolução do Congresso e convocação de novas eleições. Pelo Ato Adicional, na análise de João Camilo de Oliveira Torres (TORRES, João Camillo de Oliveira. Cartilha do Parlamentarismo. Belo Horizonte: Itatiaia, 1962. p. 56), o Presidente da República apresentaria um nome, que deveria receber a aprovação da maioria absoluta dos membros da Câmara, o que se repetiria por mais duas vezes, em caso de insucesso. Não se conseguindo qualquer resultado, o Senado indicaria um quarto nome para primeiro ministro, também por maioria absoluta. Escolhido o primeiro ministro, o gabinete se apresentaria à Câmara, para ser aprovado, agora, porém, seria suficiente a maioria simples dos presentes. O Senado, por sua vez, podia, por 
armadas.

golpe de 1964 era um golpe há muito premeditado. Os tambores da conspiração já haviam rufado, ruidosos, em 1954. Os rumores da intriga voltariam a ecoar em 1955 e em $1961^{234}$.

E os militares governariam de 1964 a 1985. Em 31 de março de 1964, as Forças Armadas depõem João Goulart e, em abril de 1964, o general Humberto de Alencar Castello Branco assume a Presidência.

O novo regime é marcado pela supressão dos direitos constitucionais, perseguição policial e militar e censura prévia aos meios de comunicação. Em 1965, os partidos políticos existentes são abolidos e cria-se o bipartidarismo.

Em 1967, o Congresso aprova nova Constituição que institucionaliza o regime, com eleições indiretas para a Presidência. O general Arthur da Costa e Silva, ministro da Guerra de Castello Branco, assume a chefia do Estado no mesmo ano e, em dezembro de 1968, fecha o Congresso e decreta o Ato Institucional n. 5

maioria absoluta, e no prazo de 48 horas, opor-se à constituição do Conselho de Ministros, sendo permitido sua rejeição pela Câmara dos Deputados em sua primeira sessão. A moção de desconfiança, pelo qual se dissolve o gabinete, dependia de um ritual complicado, devendo ser proposta por pelo menos 50 deputados e aprovada por maioria absoluta. Já a moção de confiança, pedida pelo Presidente do Conselho, dependia de maioria simples dos presentes. Se três gabinetes consecutivos fossem derrubados por moções de desconfiança, podia o Presidente da República dissolver a Câmara dos Deputados, convocando novas eleições dentro do prazo de 90 dias. Os ministros não precisavam ser membros do Congresso Nacional e podiam participar das discussões, em quaisquer das Casas. Cada ministro tinha um subsecretário de Estado que respondiam pelo expediente dos Ministérios, na fase de transição entre um gabinete e outro. $\mathrm{O}$ Presidente do Conselho de Ministros podia ocupar qualquer um dos Ministérios.

${ }^{233} \mathrm{O}$ Ato Adicional 4 esteve vigente durante um período de dezessete meses. Sobre isso, Paulo Bonavides, citando Luiz Navarro de Britto, discorre que "no Brasil, é certo, tivemos três Conselhos de Ministros em um ano, durante a vigência do Ato Adicional de 1961. Mas neste período nenhum voto de confiança Ihes foi recusado nem tampouco qualquer moção de censura foi aprovada pela Câmara. Os Gabinetes renunciaram, da mesma forma como podiam ser dispensados os Ministros em nossa Terceira República" restabelecendo-se o regime presidencial pela Emenda Constitucional 6, de 23.01.1963 (o Primeiro presidente do Conselho de Ministros foi Tancredo Neves, de setembro de 1961 a junho de 1962; o segundo foi o Gabinete de San Tiago Dantas, sucedido por Auro de Moura Andrade, que não assumiu; após, tem-se Francisco Brochado da Rocha e, finalmente, Hermes Lima). (BONAVIDES, Paulo. Curso de Direito Constitucional. 11. ed. São Paulo: Malhadas, 2001. p. 194)

${ }^{234}$ ROUQUIÉ, Alain. O Estado Militar na América Latina. São Paulo: Alga-Ômega, 1984. p. 327. 
$(\mathrm{Al}-5)^{235}$, que Ihe dá poderes para fechar o Parlamento, cassar mandatos e suprimir o habeas-corpus.

Em agosto de 1969, com Costa e Silva ${ }^{236}$ doente, assume uma junta militar que promulga uma Emenda Constitucional, que substituiu a Constituição de 1967.

Em 30 de outubro de 1969, assume Emílio Garrastazu Médici ${ }^{237}$, representante da linha dura, e comanda o período de maior repressão, marcado por prisões, torturas, exílios, mortes e o desaparecimento de muitas pessoas.

Em março de 1974, toma posse o general Ernesto Geisel, que enfrenta dificuldades econômicas em razão da crise do petróleo, inflação e dívida externa. Em 1978, é revogado o Al-5.

No ano de 1979, o general João Baptista Figueiredo torna-se presidente. Sanciona a anistia, que liberta presos políticos e permite a volta dos exilados, além de restabelecer o pluripartidarismo.

Em janeiro de 1985, o candidato da oposição Tancredo Neves, que tem como vice José Sarney, anteriormente presidente do partido governista, é eleito pelo Colégio Eleitoral. Eleito, adoece e morre antes da posse. Sarney assume e restabelece a eleição presidencial direta.

\footnotetext{
${ }^{235}$ Hélio Silva (ob. cit., p. 128) discorre que "após a edição do Al-5, iniciou-se a cassação aos políticos e cidadãos considerados inimigos do regime".

${ }^{236}$ Faleceu em 17 de dezembro de 1969.

${ }^{237}$ Hélio Silva (ob. cit., p. 130) relata que "foi um ato burocrático a comunicação que a Secretaria da Presidência da República (ocupada pela Junta Militar) fez da escolha do nome do general Emílio Garrastazu Médici, comandante do III Exército, apresentando para vice-presidente da República o nome do almirante Augusto Rademaker Grünewald. Nenhuma reunião política, conclave, convenção partidária, plataforma de governo. A Arena, o partido do governo para apoiar o governo, apoiou passivamente aquelas candidaturas."
} 
Os deputados federais e senadores se reúnem em assembléia Constituinte a partir de 1987 e, em 1988, promulgam a nova Constituição.

Sob a égide da nova Constituição, há, em 1989, as primeiras eleições diretas para a Presidência, desde 1960. É eleito Fernando Collor de Mello, que assinara o Tratado de Assunção e governa até dezembro de 1992, quando é forçado a renunciar em razão de um processo de impeachment, acusado que fora de corrupção. Seu vice, Itamar Franco assume e completa o mandato. Em 1994, Fernando Henrique Cardoso vence as eleições presidenciais, e, modificando a Constituição, se reelege em 1998. Fernando Henrique Cardoso é sucedido por Luiz Inácio Lula da Silva, em 2002, e este é reeleito em 2006.

\section{PARAGUAI}

Em 1813, o Paraguai torna-se independente da Espanha e de Buenos Aires $^{238}$. Em 1814, José Gaspar Rodríguez Francia ${ }^{239}$ isola o País até a sua morte,

${ }^{238}$ Embora a proclamação formal da independência se tenha dada apenas em 1842, no governo de Carlos Antonio López. Antes disso, a independência paraguaia não fora reconhecida, formalmente, por nenhum outro país, embora o Império Brasileiro mantivesse em Assunção, entre 1824 e 1829, um cônsul, conforme ressalta Francisco Fernando Monteoliva Doratioto (ob. cit., p. 169).

${ }^{239}$ Com o título de Ditador Perpétuo, a partir de 1815. Francia havia se afastado da Junta que governava o Paraguai, e, a pedido dos demais integrantes, Fulgencio Yegros e Pedro Juan Cavallero, retorna ao poder. Julio César Chaves salienta que "iba adquiriendo empuje en todo el país el movimiento pro-vuelta al gobierno del doctor Francia. No había surgido en la Junta el gobernante capaz de sustituirle. El gobierno tenía que afrontar serios problemas financieros, políticos e internacionales. Faltaba una dirección centrada; los oficiales del cuartel intervenían con frecuencia en asuntos ajenos a su competencia. El doctor Francia desde Ibaraí no había cesado su campaña de autopropaganda y de descrédito de sus antiguos compañeros de gobierno, ni dejado de exaltar las bajas pasiones de la plebe. Fue decisiva también en la crisis la falta de ambición de Fulgencio Yegros y de Pedro Juan Cavallero. Ambos pidieron al ausente que retornase. En acta del 16 de noviembre de 1812 declararon que en servicio de la patria resolvían ejercer la jurisdicción de gobierno 'unidamente' con el vocal-decano doctor Francia quien desde la fecha, quedaba reunido a la Junta. Mas no volvió solo e indefenso, creó un segundo batallón de infantería, del cual será comandante 'el mencionado Vocal Decano Doctor Francia. Él correrá con su arreglo, disciplina y régimen, y sin su consentimiento no se podrá disponer, dar destino, ni disolver el batallón. Recibía también 'la mitad de las municiones existentes en los parques o almacenes'. A mediados de 1813 fue separado de su cargo de vocal de la Junta, Fernando de la Mora. El doctor Francia le acusó de la pérdida del documento con el artículo adicional al tratado 
em $1840^{240}$.

Amado Luiz Cervo ${ }^{241}$ salienta que, desde a independência da Espanha, o

Paraguai sentia-se ameaçado por Buenos Aires, que chegou a invadi-lo em 1811, sem sucesso. Como resultado da vitória, cai o representante do Governo Espanhol

Velasco, instala-se o Congresso, já com a influência de Francia, que passa a governar o Paraguai, com uma Junta e, dissolvida esta, em 1814, é eleito "Presidente e Dictador Supremo de la República", por cinco anos. Em 1815, é feito pelo Congresso, Ditador Perpétuo da República pelo resto de sua vida.

Para suceder Francia é constituída uma Junta Provisória, presidida por Manuel Antonio Ortíz, substituída, em seguida por um Triunvirato com mandato expresso para convocar uma assembléia constituinte. Esta Junta foi deposta por um movimento militar, comandado por Mariano Roque Alonso, militar, com a colaboração de Carlos Antonio Lopez. Mas a convocação da assembléia foi mantida ${ }^{242}$.

del 12 de octubre y de llevar una conducta poco digna en la vida privada. Aunque el documento extraviado fue encontrado más tarde, la separación se hizo efectivaza. Francia quedó desde entonces libre de todo rival en el gobierno". (CHAVES, Julio César. Compendio de Historia Paraguaya. Asunción: El Lector, 1998, p. 134)

${ }^{240}$ Segundo Francisco Fernando Monteoliva Doratioto (ob. cit., p. 175), "o isolamento paraguaio implicou o estabelecimento de um tipo de economia no qual o Estado tornou-se regulador de todas as atividades econômicas e detentor do monopólio do comércio da erva-mate, da madeira e do tabaco. Ao confiscar terras da elite tradicional, principalmente da fração composta por espanhóis, o poder econômico do Estado paraguaio fortaleceu-se. Nessas terras, organizaram-se as Estancias de la Patria, alugadas ou exploradas pelo próprio Estado, que se utilizava também de mão-de-obra escrava ou de prisioneiros".

${ }^{241}$ DORATIOTO, Francisco Fernando Monteoliva. Ob. cit., p. 90-91.

242 Julio César Chaves (ob. cit., p. 160-161) discorre que "se aproximaba la fecha de la reunión del congreso. Los franciscas sostenían la candidatura del antiguo delegado de Misiones, Norberto Ortellado. López y sus amigos trabajan intensamente por la formación de un Consulado. El congreso se reunió en el templo de San Francisco. Al iniciarse la sesión el diputado por Barrero Grande y prócer de Mayo, Juan Bautista Rivarola, pidió se diese fin al personalismo y se dictase una constitución cuyo proyecto presentó. Carlos Antonio López desde la presidencia de la asamblea se opuso manifestando que no era el momento apropiado y que lo que este país necesitaba era un poder fuerte. Al mismo tiempo el batallón que prestaba guardia de honor comenzó a hacer evoluciones alarmantes, por lo cual Rivarola y sus partidarios tuvieron que ceder. Las principales resoluciones fueron: nombramiento como Cónsules de la República de los 
A este tempo, em 1842, Rosas pretendia anexar a Província do Paraguai à

Confederação Argentina ${ }^{243}$. Para fazer frente a isso, o Governo convoca um

Congresso extraordinário para renovar e ratificar a independência do Paraguai ${ }^{244}$. A

Bolívia é o primeiro país a reconhecer, formalmente o Paraguai, seguido do Chile e,

em 1844, pelo Brasil e em 1845, pelo Uruguai e, a Confederação Argentina, somente no governo de Urquiza ${ }^{245}$, em 1852.

Carlos Antonio López é designado Presidente ${ }^{246}$, pelo Congresso paraguaio

ciudadanos Carlos Antonio López y Mariano Roque Alonso por el término de tres años con facultades para ejercer los poderes Ejecutivo y Judicial y la comandancia general de armas".

${ }^{243}$ Julio César Chaves (ob. cit., p. 162), sobre este fato, salienta que "en octubre de 1842, llegó a la capital por vía Uruguay-Misiones, Jorge Robert Gordon, enviado confidencial de la reina de Inglaterra. Hizo el largo rodeo por haberle negado Rosas autorización para pasar por territorio argentino a 'la Provincia del Paraguay'. No tuvo buenas acogidas por su carácter particular y no oficial; aplicó además por primera vez sin autorización gubernativa la vacuna en le país. Los Cónsules le dieron perentorio plazo para abandonar el territorio nacional. Contó Gordon en una de sus conversaciones que Rosas le había expresado que 'el Paraguay deseaba incorporarse a la Confederación'. Los Cónsules resolvieron convocar un congreso extraordinario para 'renovar y ratificar' de modo solemne la declaración de la independencia".

${ }^{244}$ Julio César Chaves (ob. cit., p. 163) relata que "el congreso se reunió en el templo de la Encarnación y fue presidido por López que leyó el discurso del gobierno requiriendo una declaración solemne y enfática de la independencia. El congreso consideró que 'la emancipación e independencia es un hecho solemne e incontestable en el espacio de treinta año; que durante estos largos años se segregó con esfuerzos de la metrópoli española y se separó de hecho de todo poder extraño, queriendo desde entonces 'pertenecer a sí misma'. Por esas consideraciones la asamblea declaró que: Primero: La República del Paraguay en el de la Plata es para siempre de hecho y derecho una nación libre e independiente de todo poder extraño. Segundo: Nunca jamás será el patrimonio de una persona o familia. Estableció asimismo la obligatoriedad del juramento para gobernantes, empleados y militares de defender la integridad e independencia de la patria".

${ }^{245}$ Francisco I. Resquin argúi que "en 1852, el director provisorio de la Confederación Argentina, general don Justo José de Urquiza, despachó cerca del gobierno paraguayo un enviado especial, con suficientes poderes para la resolución de todas las cuestiones pendientes entre ambos Estados. En tal virtud, el 15 de Julio de 1852, se ajustó, concluyó y firmó con dicho enviado especial argentino doctor don Santiago Derqui, un tratado de límites, navegación y comercio, que dejaba resueltas las tres más graves cuestiones que entre los dos países había. En ese tratado se reconocía que el Paraguay es una nación soberana e independiente de todo poder extraño, y se fijaban los límites, declarándose que la navegación de los ríos Paraguay, Paraná y sus afluentes, sería libre para el pabellón paraguayo y para el argentino. Además, por medio de aquel tratado, el gobierno del Paraguay cedía al de la Confederación Argentina el territorio que desde tiempo inmemorial tenía sobre la izquierda del río Paraná, en la frontera Sud de la República. Esta cesión fue compensada con el reconocimiento de que el río Paraguay pertenece de costa a costa, con perfecta soberanía, a esta nación, hasta su confluencia en el río Paraná". (RESQUIN, Francisco I. La Guerra del Paraguay contra la Triple Alianza. Asunción: El Lector, 1996)

${ }^{246}$ Doratioto (ob. cit., p. 185-186) sustenta que "se no plano político interno, o governo de Carlos López representou uma continuidade da autocracia de Francia, nas relações exteriores o Paraguai passou a participar dos acontecimentos platinos e, já em julho de 1841, assinou com a província argentina de Corrientes, sublevada contra Rosas, dois Tratados, um de Amizade, Comércio e Navegação e, outro, de Limites. [...] Carlos López procurou romper o isolamento do País e, para tanto, o Congresso paraguaio, com o fim de obter o reconhecimento das demais nações, 
em 1844, que inicia uma política de desenvolvimento industrial autônomo, destacando-se a construção da primeira ferrovia sul-americana.

Em 1862, Francisco Solano López ${ }^{247}$, filho de Carlos, assume o poder e desenvolve uma estratégia baseada essencialmente nas exportações de produtos primários para o mercado regional e mundial, viabilizado com a liberdade de navegação existente no Prata, a partir da década de 1850.

Solano López passa a atuar mais nas questões do Prata, nos assuntos uruguaios e aproximando-se com a oposição federalista argentina, colocando Assunção em rota de colisão com a Argentina e o Brasil, ao apoiar os blancos no Uruguai $^{248}$.

proclamou solenemente a independência do Paraguai em 1842. A mudança da política externa guarani atendia principalmente à necessidade de dinamizar a economia. [...] $A$ ampliação do contato exterior do Paraguai encontrava obstáculo em Rosas, que se recusava a reconhecer sua independência e dificultava o comércio guarani com o exterior, ao controlar a navegação do rio Paraná. O líder da Confederação foi poderoso motivo para a aproximação entre o Império do Brasil e o Paraguai, ao representar ameaça para ambos".

247 Segundo Francisco Fernando Monteoliva Doratioto (ob. cit., p. 199-200), "Solano López recebeu um país para governar que não registrava dissensões internas (os opositores à ditadura tinham sido exilados, presos ou mortos), e que passava pela modernização de atividades ligadas basicamente à defesa, graças à importação de tecnologia e técnicos estrangeiros, principalmente britânicos. O financiamento da continuidade dessa modernização demandava a ampliação das exportações paraguaias. O Paraguai tinha uma área de litígio com o Brasil (área entre os rios Branco e Apa, no Mato Grosso), e este território litigioso adquiriu maior valor para Assunção, por ser área de produção de erva-mate, um dos produtos paraguaios de maior exportação. O preço da erva-mate estava deprimido e o Paraguai, para conseguir recursos monetários adicionais, teria que ampliar sua venda, à custa do produto brasileiro largamente consumido na região platina. Tal quadro levou o Paraguai a projetar-se cada vez mais para fora de suas fronteiras e a imiscuir-se nas contendas da Bacia do Prata. Era necessário uma saída segura para o mar, que parecia ser o porto de Montevidéu".

${ }^{248}$ Blancos e colorados estavam em guerra no Uruguai, Venâncio Flores, colorado, apoiado pelo Brasil e por Mitre, da Argentina, e os blancos, inicialmente com Bernardo Berro e depois com o Presidente Aguirre, que buscou ajuda política e militar de Assunção. Aguirre rompe, em 1864, relações diplomáticas com o Brasil, pelo apoio que este dava aos colorados e o governo de Assunção protestou contra qualquer ocupação do território uruguaio por forças do Império, sendo este considerado atentatório contra o equilíbrio dos Estados do Prata e que Assunção não assumia a responsabilidade pelas conseqüências de qualquer ato de represália brasileiro. O Brasil invade o Uruguai em 12 de setembro de 1864, em apoio a Flores. Em 10 de novembro, o vapor brasileiro Marquês de Olinda foi aprisionado por canhoneira paraguaia e a 24 de dezembro, as tropas paraguaias invadiram o Mato Grosso. Começava a guerra. E ao invadir Corrientes para atacar o Rio Grande do Sul, joga a Argentina a favor do Brasil. Em $1^{\circ}$ de maio de 1965, é assinado o Tratado da Tríplice Aliança contra o Paraguai, assinado em Buenos Aires. 
Em 1865, com o objetivo de ganhar território e conquistar uma saída para o mar, o Paraguai entra em guerra com o Brasil, a Argentina e o Uruguai e é derrotado ${ }^{249}$.

Salvador Jovellanos ${ }^{250}$ torna-se o presidente paraguaio, sendo sucedido

Juan Bautista Gill, ambos com o apoio brasileiro; a partir dessa data, é a influência argentina que se faz sentir ${ }^{251}$. Entre 1870 e 1932, colorados (conservadores) e liberais alternam-se no poder.

Durante a presidência do liberal Eduardo Schaerer, entre 1912 e 1916, o país atrai investimentos estrangeiros e obtém razoável nível de crescimento

${ }^{249}$ Francisco Fernando Monteoliva Doratioto (ob. cit., p. 208) sustenta que "Solano López desencadeou a guerra contra o Brasil e, em seguida, contra a Argentina, devido a uma percepção errônea do poderio nacional paraguaio. Erro esse compreensível em uma cultura política como a paraguaia, ditatorial e isolacionista. O Paraguai sequer possuía um serviço exterior, carecendo, portanto, aquele governante de informações estratégicas, que reduzissem os riscos de implementar uma política ativa para o Prata. Nessa região, centro nevrálgico dos seus interesses, Assunção não dispunha de representantes diplomáticos, contando apenas com um cônsul na cidade de Paraná e agentes comerciais em Buenos Aires e Montevidéu. Na elaboração da política externa paraguaia, faltava um processo decisório que ponderasse fatores e conseqüências da ação militar paraguaia no Prata. Governante ditatorial, Solano López não era coadjuvado por instituições estatais ao tomar decisões, quer internas, quer externas, exercendo o poder de uma forma unipessoal".

${ }^{250}$ Francisco Fernando Monteoliva Doratioto (ob. cit., p. 218) relata que "em fevereiro de 1872, os representantes do Paraguai e do Brasil, assinam um Tratado de Paz; de Limites; de Extradição e de Amizade, Comércio e Navegação. Neles, ficou estabelecido o pagamento da dívida de guerra pelo Paraguai; a continuidade das tropas brasileiras em território guarani pelo prazo que o Rio de Janeiro julgasse necessário para a manutenção da ordem e do cumprimento dos tratados; o respeito perpétuo, pelo Brasil, da independência, soberania e integridade paraguaias e o compromisso de garanti-las por cinco anos. Inviabilizou-se, a partir de então, uma ação militar da Argentina para garantir a posse do Chaco, uma vez que essa iniciativa significaria ato hostil ao Império". O Uruguai o fez em 1873 e a Argentina em fevereiro de 1876. Neste tratado, decidiu-se que as forças de ocupação se retirariam do Paraguai até 3 de junho do mesmo ano, como de fato aconteceu.

${ }^{251}$ Boris Fausto e Fernando Devoto (ob. cit., p. 121) reforçam isso ao sustentar que "após o conflito, o Paraguai foi um protetorado brasileiro de fato até 1876, e a influência política deste predominou até os primeiros anos do século XX. Mas, a partir daí, instalou-se a hegemonia econômica e política da Argentina, por várias razões. Além dos laços históricos, culturais e comerciais (o Paraguai sempre dependeu do eixo rio-platense para seu comércio exterior, antes e depois da guerra) e da menor distância entre os respectivos centros de pode, o ressentimento paraguaio era menor para com a Argentina, menos envolvida no extermínio e na devastação do país, o que compensava ou contrabalançava a influência política direta do Brasil. De fato, o Paraguai continuou orbitando na esfera rio-platense de forma bem mais acentuada que a vitória militar e a ocupação inicial brasileiras fariam supor". 
econômico. Na Guerra do Chaco (1932-35), travada contra a Bolívia, o Paraguai conquista três quartos do território em disputa, rico em petróleo.

Em 1936, um grupo de oficiais radicais liderados por Rafael Franco ${ }^{252}$ dá início à Revolução Febrerista. No poder, Franco realiza a reforma agrária e nacionaliza parte da economia, mas é derrubado pelos liberais em 1937. Em 1939, as eleições levam à Presidência o general José Félix Estagarribia. Ele morre em um acidente aéreo em 1940 e é substituído pelo general Higino Moríñigo.

Após a deposição de Moríñigo em 1948, golpes e contragolpes sucedem-se até 1954, quando o comandante do Exército, general Alfredo Stroessner derruba o presidente Frederico Chávez e instala um regime ditatorial ${ }^{253}$. As rebeliões oposicionistas de 1959 e 1964 são esmagadas. A partir de 1968 há participação limitada da oposição nas eleições.

O governo Stroessner ${ }^{254}$ é marcado pelo domínio do Partido Colorado 255 sobre o Estado, pela corrupção institucionalizada e pela repressão aos oposicionistas.

${ }^{252}$ ROUQUIÉ, Alain. O Estado Militar na América Latina, p. 214-215.

${ }^{253}$ Ceres Moraes salienta que "consumado o golpe, Stroessner - senhor da situação - não assumiu imediatamente o comando do governo. Provavelmente para dissimular seus verdadeiros objetivos e angariar simpatias e apoio civil, entregou a solução da crise institucional, por ele gerada, à Junta de Governo do Partido Colorado, que rapidamente indicou Romero Pereira para presidente provisório, marcou a eleição presidencial para o dia 12 de julho e indicou Stroessner como candidato do partido. Dessa forma, ele assumiu o poder como presidente eleito e não como usurpador". (MORAES, Ceres. Paraguai - A consolidação da ditadura de Stroessner - 1954-63. Porto Alegre: EDIPUCRS, 2000. p. 48)

${ }^{254}$ ROUQUIÉ. Alain. O Estado Militar na América Latina, p. 215-216.

${ }^{255}$ Fabio Aníbal Jará Goiris, no livro Autoritarismo e Democracia no Paraguai Contemporâneo, analisa que havia duas facções governistas, ambos do Partido Colorado, os chamados "tradicionalistas" e os "militantes", ou "duros", e é a disputa do poder entre estes, a partir da convenção do partido Colorado em 1987, e que vai culminar com o golpe palaciano. (JARÁ GOIRIS, Fabio Aníbal no livro Autoritarismo e Democracia no Paraguai Contemporâneo, Paraná: UFPR, 2000, p. 114-115). E, também Roberto Paredes e Liz Varela reforçam: "La convención colorada del $1^{\circ}$. de agosto de 1987 señaló el comienzo del fin del stronismo. En esa ocasión, la corriente denominada 'militante combatiente y stronista hasta las últimas consecuencias', encabezada por Sabino Augusto Montanaro, Mario Abdo Benítez, J. Eugenio Jacques y Adán Godoy Jiménez - el 'cuatrinomio de oro' -, se tornó no simplemente hegemónica en la conducción del Partido Colorado, sino excluyente, pues las demás tendencias internas de peso: 'tradicionalistas' y 'éticos', quedaron fuera de la administración partidaria". (PAREDES, Roberto; VARELA, Liz. LOS CARLOS - Historia del Derrocamiento de Alfredo Stroessner. Asunción: Ser Vilibro, 2005. p. 12) 
Em função dessa repressão, há esfriamento nas relações com os EUA em 1980. A partir de 1983, antigos exilados começam a retornar ao Paraguai. Em 1987, Domingo Laíno volta para liderar a frente de oposição Acordo Nacional.

Em fevereiro de 1989, Stroessner ${ }^{256}$ é deposto por um golpe militar e asila-se no Brasil. O líder do golpe é o comandante do Exército general Andrés Rodríguez, eleito presidente em maio do mesmo ano. Ele deixa o poder em 1993, sucedido pelo empresário, também pertencente ao partido colorado, Juan Carlos Wasmosy que governa sem a maioria no Senado e na Câmara.

Com a aprovação da lei proibindo manifestações políticas dos militares, há a desavença entre o governo e o comandante do Exército general Lino Oviedo, este após tentar tomar o poder, é preso e condenado. Lino Oviedo é vitorioso na escolha pelo partido colorado a presidente, mas, tornado inelegível por sentença da Corte Suprema, é substituído por Raúl Cubas, que liberta Oviedo à revelia da Corte Suprema.

O vice-presidente eleito, Luis Maria Argaña, rival de Oviedo, é morto. Cubas, aliado de Oviedo é forçado a renunciar. Assume a presidência Luis González Macchi, presidente do Congresso. Em maio de 2000, militares rebeldes e policiais sublevam-se, mas o golpe fracassa.

Os partidários de Oviedo ajudam o oposicionista Júlio César Franco do PLRA (liberal), a derrotar nas urnas o candidato colorado, para o cargo de vicepresidente. Eleito pelo voto direto, Franco passa a afirmar que tem mais legitimidade que Macchi, que assumiu a Presidência sem ter sido eleito. Luís González Macchi, presidente do Congresso que enfrenta e sobrevive a um pedido de impeachment. Macchi é sucedido em 2003 por Nicanor Duarte.

\footnotetext{
${ }^{256}$ Sobre a ditadura de Stroessner ver: MORAES, Ceres. Paraguai - A consolidação da ditadura de Stroessner - 1954/63. Porto Alegre: EdiPUCRS, 2000. Sobre a história do Paraguai ver: CHAVES, Julio César. Compendio de Historia Paraguaya. Cerro Corá y Tacuary, 1994.
} 


\section{URUGUAI}

O Uruguai fazia parte do Vice-Reinado do Prata em 1776. Entre 1810 e 1814, José Gervasio Artigas lidera uma insurreição armada e domina Montevidéu, que seria a seda da Federação do Prata. Mas Buenos Aires envia reforços contra Artigas, que é derrotado em 1816.

Em 1817, o Uruguai é ocupado por forças luso-brasileiras, sendo anexado ao Brasil em 1821, sob o nome de província Cisplatina. Em 1825 257 , um grupo de patriotas conhecidos como os "33 orientais", liderados por Juan Antonio Lavalleja, proclama a independência uruguaia e reúne tropas que, com a ajuda da Argentina, expulsam os brasileiros, em 1827. Com apoio da Inglaterra, o Uruguai ratifica, em 1828, sua independência do Brasil e da Argentina, pelo Tratado do Rio de Janeiro ${ }^{258}$. O crescente antagonismo entre colorados (liberais, liderados por Fructuoso Rivera) e blancos (conservadores, chefiados por Manuel Oribe) provoca uma guerra civil entre 1839 e $1852^{259}$. Inglaterra e França intervêm a favor dos colorados e a Argentina, dos blancos. O caudilho argentino Juan Manuel Rosas ordena a invasão

${ }^{257}$ Gonzalo Abella ilustra esta passagem, salientando "el año de 1825 es crucial. El 19 de abril, el escenario principal es una pequeña playa arenosa en la margen oriental del Río Uruguay. (...) Desde suelo argentino llegan a esa playa, en silenciosos lanchones, un puñado de hombres armados. Después la historia los llamaría 'los Treinta y Tres'. Los argentinos han financiado esta Cruzada Libertadora con rara unanimidad, y entre ellos los federales han puesto como jefe al oriental Juan Antonio Lavalleja". (ABELLA, Gonzalo. Historia diferente del Uruguay. 4. ed. Montevideo: Betun San, 2007. p. 111)

${ }^{258}$ Segundo Juan José Arteaga, "el Uruguay nació a la vida independiente con una debilidad demográfica congénita. Tenía sólo 74.000 habitantes para sus casi 178.000 kilómetros cuadrados". (ARTEAGA, Juan José. URUGUAY - Breve Historia contemporánea. Cidade do México: Fondo de Cultura Económica, 2000. p. 66)

${ }^{259}$ Alain Rouquié argúi que no Uruguai, "o sistema partidário, que constitui a chave de ouro da vida nacional e remonta à criação do país, divide os cidadãos, quase que hereditariamente, em dois partidos: blanco e colorado. Os partidos são verdadeiras comunidades, durante muito tempo em guerra uma contra a outra, nas quais a identificação partidária é muito forte. Isso porque a pessoa não se torna, mas nasce blanco ou colorado, e essas 'pátrias subjetivas', que são as duas grandes famílias e principalmente o partido colorado urbano, desempenharam um papel essencial na assimilação dos imigrantes europeus do fim do século XIX até a crise dos anos trinta".(ROUQUIÉ, Alain. O Estado Militar na América Latina, p. 276) 
do país, mas ele é deposto em 1852 e os invasores se retiram. Em fins de 1851, realizaram-se eleições para o Congresso uruguaio que, por sua vez, elegeu o Presidente da República, o blanco Juan Francisco Giró, mas a luta prossegue ${ }^{260}$.

O Brasil intervém, em 1854, a favor dos colorados, retirando-se em 1855.

Em 1864, o Brasil intervém no Uruguai para apoiar o caudilho colorado Venâncio

Flores, que invadira o Uruguai em abril de 1863, em sua luta contra os blancos, estes pedem auxílio a Solano López ${ }^{261}$. Em contrapartida o Uruguai participa, entre 1865 e 1870, da aliança com o Brasil e Argentina na Guerra do Paraguai.

Entre 1870 a 1900, há um acelerado crescimento econômico, com grandes investimentos britânicos na região ${ }^{262}$. O Estado se enriquece adotando um modelo

${ }^{260}$ A Guerra Grande. Geraldo Caetano e José Rilla sustentam que "fue solo a partir de la Guerra Grande y de su hondo impacto comarcal que se produjo la primera definición del contenido de las divisas. Blancos y colorados se dividieron entonces ante el desafío de algunos de los principales dilemas del conflicto regional: desde la definición de fronteras a la confrontación en torno a los modelos modernizadores más aptos para el primer desarrollo autónomo de estas regiones, pasando por la controversia armada en torno a la adscripción territorial de las hegemonías caudillescas y sus séquitos. (...) podría señalarse que 'lo colorado' comenzó desde entonces a ser sinónimo de: una relación privilegiada con el poder institucionalizado como instancia de construcción sociopolítica; un estilo de 'hacer política' más contractual; la defensa de un modelo modernizador básicamente imitativo, en el que se partía del reconocimiento del 'afuera' principalmente Europa - como 'imagen constitutiva' y 'mirada constituyente'; la adscripción por último a una identidad más ciudadana e inmigrante. Por su parte, en una perspectiva analítica similar, 'lo blanco' podría identificarse desde entonces con: la desconfianza frente al poder institucionalizado y una mayor adhesión al 'llano como ámbito desde donde hacer la política'; un estilo político más agonal y romántico; la defensa de un modelo modernizador más selectivo y autorregulado, proclive a la afirmación de fronteras sólidas entre el 'adentro' y el 'afuera'; la asociación privilegiada con el mundo rural y sus símbolos, de índole más localista que cosmopolita". (CAETANO, Geraldo; RILLA, José. Historia Contemporánea del Uruguay. 3. ed. Uruguay: Claeh, 2006. p. 65)

${ }^{261}$ Francisco Fernando Monteoliva Doratioto (ob. cit., p. 203) discorre que "o governo blanco uruguaio não se deixou intimidar e responsabilizou o Brasil e a Argentina pela guerra civil, por terem os dois países dado a organização de tropas hostis a Montevidéu em seus respectivos territórios. $O$ presidente Aguirre, blanco, buscou ajuda de Assunção, afirmando a Solano López pretender o Brasil anexar uma porção do território uruguaio e a Argentina o que sobrasse, ou, então, o controle do governo oriental".

${ }^{262}$ Geraldo Caetano e José Rilla (ob. cit., p. 94) sustentam que "en 1875 las inversiones británicas en el Uruguay se aproximaban a los diez millones de libras esterlinas; en la década del ochenta, a los veinticinco millones, y a cuarenta millones hacia 1900. Las inversiones inglesas en el Uruguay eran mayores que las realizadas en África Occidental, y el país estaba unido a Inglaterra por la más alta deuda per cápita de toda América del Sur". 
exportador agropecuário e um centralismo político ${ }^{263}$.

Em 1904, os blancos se revoltam contra o presidente colorado José Betlle y

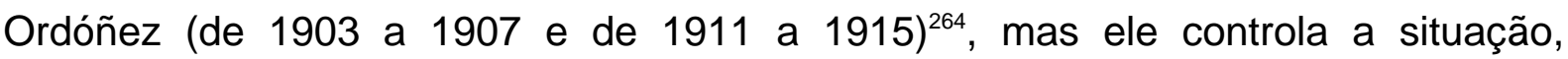
nacionaliza os serviços públicos e algumas indústrias e cria o primeiro sistema de previdência social na América Latina ${ }^{265}$. Em 1913, Betlle propõe, para as eleições seguintes, uma nova Constituição, apresentando um projeto em que visava substituir o sistema presidencialista por um sistema colegiado ${ }^{266}$. A reação a esta proposta divide e cinde o Partido Colorado ${ }^{267}$ que estava no poder.

Em 1916, se adotado o voto secreto, é realizada as eleições para a Assembléia Nacional Constituinte, e, com a ajuda dos dissidentes a oposição triunfa $^{268}$ na Assembléia, com isso o Governo transige e os dissidentes colorados

${ }^{263}$ Geraldo Caetano e José Rilla (ob. cit., p. 96) argúem que "las tribulaciones políticas desencadenadas entre 1873 y 1876, expresión entre otras cosas de un vacío de poder, resultaron finalmente la ocasión propicia para la implantación de un modelo político autoritario con el sustento del Ejército, el apoyo de los empresarios y tal vez cierta aquiescencia del pueblo y sus principales aunque menoscabados caudillos partidarios".

${ }^{264}$ Juan José Arteaga (ob. cit., p. 143) lembra que "ser batllista en esos años era ser progresista, avanzado, que defendía al obrero y atacaba el latifundio tradicional, partidario del estatismo económico y de las nacionalizaciones con la intención de que las utilidades favorecieran a los ciudadanos del país. Ser batllista implicaba también enviar a los hijos a la escuela pública y laica, casarse por lo civil y rechazar el matrimonio religioso y aceptar la liberación de la mujer favoreciendo su acceso a los estudios secundarios y universitarios".

265 Geraldo Caetano e José Rilla (ob. cit., p. 114) afirmam que "en el pleno económico y social, el impulso batllista promovió cambios de importancia en las relaciones entre el Estado y la economía, en el proceso de industrialización, en las políticas agropecuarias y fiscales, en las políticas sociales y en la legislación laboral, entre otros. La estrategia de estatización y de nacionalización suponía integrar al dominio industrial, comercial y financiero del Estado algunas áreas consideradas como servicios públicos o de carácter relevante y estratégico. Ello podía requerir la eliminación o el relevo del capital privado, ya fuera éste extranjero o nacional, pero reportaría ganancias a Estado mismo (si las empresas eran eficientes) y lograría extender los servicios y abaratar su costo".

266 Juan José Arteaga (ob. cit., p. 143-144) comenta que "en marzo de 1913, Batlle se abocó a la gran reforma política al dar a conocer en sus 'Apuntes' su propuesta colegialista, que en esencia proponía sustituir al presidente de la República por una Junta Nacional de Gobierno integrada por nueve miembros. Dos de ellos serían elegidos por el poder legislativo y los siete restantes directamente por el pueblo. Los primeros durarían seis años en su mandato y los segundos siete. Éstos se renovarían a razón de uno por año".

267 Liderados por Pedro Manini Rios, se declaram anti-colegialistas e formam o Partido Colorado Fructuoso Rivera, passando a ser conhecidos como "riveristas".

268 Os Blancos do Partido Nacional elegem 105 constituintes, seguidos por 87 do Partido Colorado Batllista, 22 para os dissidentes Colorado Riverista, 2 para os socialistas e 2 para o civismo. Juan José Arteaga (ob. cit., p. 148) salienta que "la derrota del 30 de julio de 1916 fue no sólo la derrota 
refluem. Para superar o impasse é criada uma Comissão composta por quatro Blancos e quatro batllistas e com base no projeto desta Comissão, submetida à aprovação da Assembléia e aprovado por plebiscito é promulgada a Constituição de $1919^{269}$. O sistema resultante da Constituição funciona normalmente até o golpe de Estado de 1933.

Batlle é sucedido por Feliciano Vieira (1915-1919) e este é, por sua vez, é sucedido por Baltasar Brum (1919-1923), José Serrato (1923-1927), e, este, pelo riverista Juan Campisteguy (1927-1931). Durante o governo deste, a crise mundial de 1929, atinge fortemente o Uruguai e, em meio a crise, assume Gabriel Terra, em 1931, com partidos políticos fracionados. Terra defendia a eliminação da dualidade existente no poder executivo em favor do sistema parlamentarista, mas enfrenta a oposição dos batllistas. Forma então uma coalizão informal com a dissidência do partido Blanco, o Partido Nacional Independente, liderado por Luis Alberto de Herrera e com riveristas, tradicionais inimigos do sistema colegial, e promove um Golpe de Estado, em 1933 ${ }^{270}$, suspendendo a Constituição de 1919.

del proyecto colegiado, sino también la derrota del reformismo radical, provocada por el fin de la prosperidad que había vivido la República entre 1905 y 1912. Frente al adverso resultado, el presidente Vieira hizo pública su voluntad de cambiar de política, hacer un 'alto' en la legislación social y económica y frenar el reformismo, que había alarmado a tantos y dividido al Partido Colorado. Era un llamado a la unificación del Partido, a la conciliación del capital y el obrero, al realismo político. Ése fue el espíritu del llamado "alto" de Viera y el fin del reformismo".

${ }^{269}$ A Constituição de 1919, apesar de formalmente presidencialista, é híbrida em sua estrutura e implicou em um compromisso entre os adeptos do sistema colegial e do sistema presidencialista. Juan José Arteaga (ob. cit., p. 150) discorre que "la composición del poder ejecutivo era bicéfalo. Estaba integrado por el presidente de la República, que era elegido directamente por el pueblo, duraba cuatro años en sus funciones, y de él dependían los ministerios de Relaciones Exteriores, Interior y Guerra, y el Consejo Nacional de Administración. Ese órgano novedoso estaba integrado por nueve miembros, elegidos directamente por el voto popular y renovables en su tercera parte cada dos años. En cada elección correspondía elegir tres consejeros, dos por la mayoría y uno por la minoría. Duraban seis años en sus funciones. De este Consejo dependían los ministerios de Hacienda, Industrias, Trabajo y Comercio, Justicia e Instrucción Pública y Obras Públicas".

${ }^{270}$ Geraldo Caetano e José Rilla (ob. cit., p. 216) salientam que a "llamada 'concordancia dictatorial' encontraba su conductor. Se trataba de una relación de mutua convivencia en la que Terra sabía muy bien qué fibras debía tocar para renovar periódicamente la convergencia de fuerzas tras su nombre. Las ideas convocantes serían simples y efectivas: la reforma constitucional para terminar con la 'irresponsabilidad gubernamental', el peligro de la 'agitación' comunista estimulada desde afuera; un gobierno 'ágil' y 'barato' que sustituyera la 'politiquería'”. 
Em 1934 é aprovada nova Constituição ${ }^{271}$, sendo eleito, pela Assembléia

Constituinte, Gabriel Terra, presidente da República pelo período de 1934-1938.

Gabriel Terra é sucedido por seu cunhado o General Alfredo Baldomir, que rompe

com os terristas e herreristas. Em 1942, Baldomir realiza um golpe de Estado,

dissolvendo o parlamento e assumindo a totalidade dos poderes e se afasta em

1943, depois de aprovar, em 1942, nova Constituição ${ }^{272}$. Baldomir é sucedido por

Juan J. Amézaga (1943-1947), com um retorno às idéias batllistas ${ }^{273}$ e este é

sucedido por Tomás Berreta, que falece seis meses depois e é sucedido por seu

271 José Arteaga (ob. cit., p. 184-185) ressalta que a Constituição de 1934 manteve o Estado na forma republicana, laica, democrática e representativa e "cuanto al gobierno, la Constitución estableció un régimen parlamentario atenuado, y el poder ejecutivo se atribuyó al presidente de la República y sus ministros. El Consejo de Ministros se integró con nueve miembros designados por el presidente, quien debía elegir por lo menos a tres ministros del partido que siguiera en número de votos al ganador. En otras palabras, se establecía la coparticipación en el gabinete, garantizando tres cargos para el Partido Nacional. El poder legislativo mantuvo el sistema bicameral, pero sufrió modificaciones importantes en la composición del Senado. Éste constaría de 30 miembros y sería presidido por el vicepresidente de la República. No se integraba por el principio de la representación proporcional, como la Cámara de Diputados, sino que 15 senadores se elegían del partido más votado, y los otros 15 , de la lista más votada dentro del lema de la minoría mayor. Quedaron excluidas las otras minorías".

${ }^{272}$ Segundo José Arteaga (ob. cit., p. 192-193), ela mantinha, em linhas gerais, a Constituição de 1934, mas altera a base política em que esta se assentava. "Los senadores volvieron a ser elegidos por el sistema de representación proporcional integrada eliminando la cuota fija determinada en el Senado del ' 15 y15'. En el poder ejecutivo se suprimió la coparticipación obligatoria en el gabinete, que otorgaba tres carteras a la minoría mayor. Para los defensores de la Constitución de 1934, esta coparticipación se basaba en la realidad histórica y política del país y sustituía las posiciones perdidas por el segundo partido al desaparecer el Consejo Nacional vigente entre 1919 y 1933. en cambio, el proyecto de 1942 establecía que el presidente de la República designaba a los ministros, liberado de cuotas fijas, entre las personas que contaran con respaldo parlamentario. Los cargos de los directorios de los entes autónomos y servicios descentralizados eran designados por el poder ejecutivo en el Consejo de Ministros, con la venia del Senado. Aquí también se eliminó el sistema de coparticipación".

${ }^{273}$ Geraldo Caetano e José Rilla (ob. cit., p. 241) ressaltam, contudo, "la diferencia notoria de contextos históricos (en los años cincuenta se había completado el cambio de hegemonías en el mundo capitalista y la inserción internacional del país ya no podía ser la misma que a comienzos de siglo; el sistema político democrático y la propia estructura social se encontraban configurados de modo mucho más consistente y sus condicionamientos ya no eran los de aquellos 'tempos de formación' del 900; el debate ideológico se desarrollaba bajo otras coordenadas), un rápido vistazo comparativo entre el batllismo originario y su nueva versión ofrece réditos interpretativos. Las semejanzas en el discurso eran múltiples: la afirmación liberal con una proyección social y en algún caso moderadamente socializante; la promoción de un Estado reformista, que no sustituyera la iniciativa privada pero que permitiera 'dirigir' la articulación armónica de los intereses del capital y del trabajo; la invocación del rol anticipatorio de las políticas públicas, con el fin de garantizar las estrategias de concertación social y prevenir la eventualidad de cualquier 'desorden revolucionario'; la promoción de la industrialización como clave del desarrollo económico y de la redistribución más justa de los ingresos; la ratificación del alineamiento panamericanista". 
vice-presidente Luis Batlle Berres (1947-1951), sobrinho de Batlle y Ordóñez, Betlle.

Este é sucedido por Andrés Martínez Trueba. Trueba apresenta e consegue fazer

aprovar uma nova Constituição em 1952, que adotava um regime de Colegiado

Integral $^{274}$ na organização do Poder Executivo ${ }^{275}$.

Esta situação perdura até 1966, quando um referendo simultâneo às eleições, vencidas pelos colorados, restaura o presidencialismo ${ }^{276}$.

${ }^{274}$ Daí porque o Uruguai passa a ser chamado de Suíça sul-americana, em uma referência ao sistema vigente naquele país que é de um Poder Executivo Colegiado. Embora Geraldo Caetano e José Rilla (ob. cit. 245) citem que "el ex presidente Luis Batlle contaba que, de viaje por Europa no vacilaba en invertir los términos de la viaja metáfora, para espetar a sus anfitriones suizos que, en realidad, eran ellos 'los uruguayos de Europa'".

275، Juan José Arteaga (ob. cit., p. 217-219) sintetiza as características desta nova Constituição salientando que "mantenía la mayor parte de las normas aceptadas en las cartas anteriores, y las principales reformas se referían a la organización de los poderes ejecutivo y legislativo. El poder ejecutivo era ejercido por el Consejo Nacional de Gobierno, integrado por nueve miembros, elegidos directamente por el pueblo cada cuatro años. Al lema más votado se le adjudicaban seis cargos de consejeros, los cuales corresponderían a la lista más votada dentro del lema, siempre que otra lista, diferenciada por un sublema propio y permanente, no superara la sexta parte de los votos emitidos dentro del lema, pues en caso contrario le corresponderían sólo cinco cargos a la lista más votada y un cargo a la que le siguiera en número de votos. Los tres cargos restantes se adjudicaban al lema que siguiera en orden de votos, y dentro de éste la distribución se haría proporcionalmente entre los sublemas que concurrían a la elección bajo dicho lema. La fórmula adoptada, colegiado integral con representación bipartita, suponía establecer una coparticipación de los dos partidos mayoritarios en la integración del Consejo, pero esto no implicaba colaboración alguna en la gestión de gobierno. Se volvía al principio político de la coparticipación asumido en la Constitución de 1934, que en ese texto se concretaba por medio de la integración del Senado y de la distribución de los ministerios, tres de los cuales se debían entregar obligatoriamente al segundo partido. Allí la coparticipación implicaba un cogobierno directo. En cambio, en la Constitución de 1952 la coparticipación sólo implicaba la necesaria integración del Consejo. En los hechos funcionó como una forma de control de la minoría sobre la mayoría más que como una fórmula de cooperación política. La presidencia del Consejo era rotativa, por periodos anuales, entre los cuatro primeros consejeros electos bajo el lema mayoritario y por orden de colocación en la lista representativa. Los consejeros no podían ser reelegidos sino después de transcurridos cuatro años entre su cese y la fecha de toma de posesión. Es decir, se les aplicó el mismo impedimento que tuvieron los presidentes de la República en las constituciones de 1830, 1919, 1934 y 1942. el poder legislativo siguió siendo bicameral. La Cámara de Representantes se componía de 99 miembros, elegidos directamente por el pueblo con arreglo a un sistema de representación proporcional. La Cámara de Senadores se integraba por 31 miembros, elegidos directamente por el pueblo, considerándose a la República como una sola circunscripción electoral. La presidencia del Senado y de la asamblea general era desempeñada por el primer titular de la lista más votada dentro del lema más votado".

${ }^{276}$ Gerónimo de Sierra comenta que "en lo que hace a la estructura del Poder Ejecutivo, en 1918 se abandonó el presidencialismo unipersonal de 1830 por el régimen mixto o semi-colegiado (se repartía el poder entre el presidente y un Consejo de Administración); luego se pasó nuevamente al presidencialismo unipersonal que se mantuvo en 1934 y 1942; en 1952 se instauró un Ejecutivo colegiado bipartidista de nueve miembros (único caso en América Latina), para finalmente volverse al presidente único en 1966". (SIERRA, Gerónimo de. Sistema político, sistema de partidos y régimen electoral en el Uruguay. In: TAVARES, José Antônio Giusti; ROJO, Raúl Enrique (Orgs.). Instituições Políticas Comparadas dos Países do MERCoSUL. Rio de Janeiro: Fundação Getúlio Vargas, 1998. p. 49) 
O declínio econômico uruguaio provoca o aumento da inflação, dos protestos populares e da ação dos Tupamaros, grupo guerrilheiro de esquerda, surgido em 1963. Nas eleições de 1971, Juan Maria Bordaberry, colorado, é eleito presidente. Apoiado pelos militares, em 1973, Bordaberry ${ }^{277}$ fecha o Congresso, suspende a Constituição e instaura um regime repressivo. Em 1976 é substituído ${ }^{278}$ por Aparício Méndez.

Em 1980, as Forças Armadas são derrotadas em um plebiscito para referendar uma nova Constituição e, diante da aguda crise econômica, decidem dividir responsabilidades com os civis. O general Gregório Alvarez chefia o governo de transição. As eleições de novembro de 1984 dão vitória ao colorado Julio Maria Sanguinetti. Em 1989, a Lei do Ponto Final, que anistia os militares repressores durante a ditadura é aprovada em plebiscito.

Ainda em 1989, Luis Alberto Lacalle, candidato do Partido Nacional (PN, blanco), vence as eleições presidenciais. Ele implementa uma política neoliberal de privatizações, corte de gastos públicos e arrocho salarial, que provoca grandes resistências. As reformas não avançam. A economia segue estagnada. Alguns de seus auxiliares são presos sob acusação de corrupção. No plano internacional, assina o Tratado de Assunção.

Em 1994, nas eleições gerais, vence o colorado Julio Sanguinetti, que volta à Presidência no ano seguinte. Em 1995, o Legislativo aprova o aumento dos impostos, os cortes nos gastos públicos e a reforma do sistema previdenciário e, em 1996, é a vez de uma reforma constitucional para mudanças do sistema eleitoral. Em 1999, após disputada eleição, é eleito o colorado Jorge Batlle. Nas eleições de 2004, a esquerda vence, com o candidato da Frente Ampla, Tabaré Vázquez.

\footnotetext{
${ }^{277}$ ROUQUIÉ, Alain. O Estado Militar na América Latina, p. 296.

${ }^{278} \mathrm{Na}$ verdade ele foi destituído pelos militares, assume em seu lugar Alberto Demicheli, presidente do Conselho de Estado, até a designação de novo presidente.
} 


\section{O PODER EXECUTIVO, O SISTEMA PRESIDENCIALISTA E A CONSTITUIÇÃO}

No âmbito da Constituição da Argentina, de 1994, as atribuições do Presidente da República se enquadram em três funções básicas do Poder

Executivo $^{279}$ : (1) Chefia do Estado, com as matérias relacionadas nos artigos 99, 11,

12, 1, 16, 18. (2) Chefia de Governo, com as matérias indicadas nos artigos 80, 99, 1, primeira parte, $2,3,4,5,7,8,9,10,13,14,17,19,20$. (3) Chefia da Administração, com as matérias previstas no artigo 99, 1 segunda parte, 6.

$\mathrm{Na}$ Constituição Argentina, ao mesmo tempo em que se atribui ao Presidente da Republica, no artigo 99, 1, a condição de chefe supremo da Nação, chefe de governo e responsável político pela administração geral do país, há, formalmente, uma mitigação da concentração de poderes do Presidente da República $^{280}$, ao se atribuir, igualmente, à pessoa do Chefe de Gabinete dos Ministros, em seu artigo 100, última parte, a responsabilidade política frente ao Congresso $^{281}$, e, neste mesmo artigo, tornando-o responsável pelo exercício da

${ }^{279}$ Utilizando-se da classificação apresentada por SILVA, José Afonso da. Curso de Direito Constitucional Positivo. 19. ed. São Paulo: Malheiros, 2000.

${ }^{280}$ Apesar disso, Raúl Enrique Rojo ressalta, de modo bem claro, que "la institución más importante de la República Argentina es el presidente. Esta situación relevante se manifiesta en dos esferas: por un lado en el avance considerable de los poderes presidenciales a costa de los del Congreso. Por otro, en cierto aspecto que excede largamente la mera ampliación de competencias, a saber: en la conversión del presidente en conductor político del pueblo argentino, pues el significado político de su gestión no será juzgado únicamente en función de las medidas llevadas a cabo por él, sino más bien por el interés y los impulsos que haya sido capaz de despertar en su pueblo". (ROJO, Raúl Enrique. El Sistema Político Argentino. In: TAVARES, José Antônio Giusti; ROJO, Raúl Enrique (Orgs.). Instituições Políticas Comparadas dos Países do MERCosUL. Rio de Janeiro: Fundação Getúlio Vargas, 1998. p. 95)

${ }^{281}$ Contudo, N. Guillermo Molinelli e outros não crêem nessa mitigação formal. De fato sustentam que em "el marco de un diseño presidencial la rama ejecutiva en Argentina ha sido y es unipersonal, estando a cargo de un Presidente. Si bien desempeña su tarea con la colaboración de Ministros, éstos no forman en conjunto un órgano colectivo con facultades decisorias propias. Es cierto que es usual hablar de 'gabinete' (denominación incorporada a la Constitución por la reforma de 1994) y que en algunas épocas hubo decisiones Del Presidente que se decían formalmente tomadas 'en acuerdo de ministros' (expresión, junto con la de 'acuerdo de gabinete' incorporada también en 1994) pero no hay decisiones colectivas de Ministros sin alguna intervención Del Presidente y, en definitiva, la facultad de este último de remover a los Ministros define el tema". (MOLINELLI, N. Guillermo et al. Congreso, Presidência y Justicia em Argentina. Buenos Aires: Temas, 1999. p. 519) 
administração geral ${ }^{282}$, com as ressalvas do artigo 99, 1 segunda parte, e 6.

No Brasil, adotando-se o mesmo critério ${ }^{283}$, analisando-se a Constituição de

1988, para o sistema presidencialista brasileiro, as atribuições do Presidente da

República se enquadram em três funções básicas do Poder Executivo: (1) Chefia do

Estado, com as matérias relacionadas no artigo 84, VII, VIII, XVIII, segunda parte, XV (nomeação de um terço dos membros do TCU), XVI, primeira parte, XIX, XX, XXI

e XXII; (2) Chefia de Governo, com as matérias indicadas no artigo 84, I, III, IV, V,

${ }^{282}$ De fato, compete ao Chefe de Gabinete dos Ministros conforme dispõe o art. 100. "El jefe de gabinete de ministros y los demás ministros secretarios cuyo número y competencia será establecido por una ley especial, tendrán a su cargo el despacho de los negocios de la Nación, y refrendarán y legalizarán los actos del presidente por medio de su firma, sin cuyo requisito carecen de eficacia. Al jefe de gabinete de ministros, con responsabilidad política ante el Congreso de la Nación, le corresponde: 1.- Ejercer la administración general del país. 2.- Expedir los actos y reglamentos que sean necesarios para ejercer las facultades que le atribuye este artículo y aquellas que le delegue el presidente de la Nación, con el refrendo del ministro secretario del ramo al cual el acto o reglamento se refiera. 3.- Efectuar los nombramientos de los empleados de la administración, excepto los que correspondan al presidente. 4.- Ejercer las funciones y atribuciones que le delegue el presidente de la Nación y, en acuerdo de gabinete resolver sobre las materias que le indique el Poder Ejecutivo, o por su propia decisión, en aquellas que por su importancia estime necesario, en el ámbito de su competencia. 5.- Coordinar, preparar y convocar las reuniones de gabinete de ministros, presidiéndolas en caso de ausencia del presidente. 6.Enviar al Congreso los proyectos de ley de Ministerios y de Presupuesto nacional, previo tratamiento en acuerdo de gabinete y aprobación del Poder Ejecutivo. 7.- Hacer recaudar las rentas de la Nación y ejecutar la ley de Presupuesto nacional. 8.- Refrendar los decretos reglamentarios de las leyes, los decretos que dispongan la prórroga de las sesiones ordinarias del Congreso o la convocatoria de sesiones extraordinarias y los mensajes del presidente que promuevan la iniciativa legislativa. 9.- Concurrir a las sesiones del Congreso y participar en sus debates, pero no votar. 10.- Una vez que se inicien las sesiones ordinarias del Congreso, presentar junto a los restantes ministros una memoria detallada del estado de la Nación en lo relativo a los negocios de los respectivos departamentos. 11.- Producir los informes y explicaciones verbales o escritos que cualquiera de las Cámaras solicite al Poder Ejecutivo. 12.Refrendar los decretos que ejercen facultades delegadas por el Congreso, los que estarán sujetos al control de la Comisión Bicameral Permanente. 13.- Refrendar conjuntamente con los demás ministros los decretos de necesidad y urgencia y los decretos que promulgan parcialmente leyes. Someterá personalmente y dentro de los diez días de su sanción estos decretos a consideración de la Comisión Bicameral Permanente. El jefe de gabinete de ministros no podrá desempeñar simultáneamente otro ministerio.

Artículo 101. El jefe de gabinete de ministros debe concurrir al Congreso al menos una vez por mes, alternativamente a cada una de sus Cámaras, para informar de la marcha del gobierno, sin perjuicio de lo dispuesto en el artículo 71. Puede ser interpelado a los efectos del tratamiento de una moción de censura, por el voto de la mayoría absoluta de la totalidad de los miembros de cualquiera de las Cámaras, y ser removido por el voto de la mayoría absoluta de los miembros de cada una de las Cámaras".

${ }^{283}$ MOLINELLI, N. Guillermo et al. Ob. cit., p. 549-550. 
IX, X, XI, XII, XIII, XIV, XVII, XVIII, primeira parte, XXIV e XXV; (3) Chefia da Administração federal, com as matérias previstas no art. 84, II, VI, XVI, segunda parte, XXIV e XXV.

No primeiro inciso do art. 84, dá-se ao Presidente a competência de nomear e exonerar os Ministros de Estado, significando que a responsabilidade política é inteiramente do Presidente.

No âmbito da Constituição de 1992, do Paraguai, as atribuições do Presidente da República estão assim enquadradas: (1) Chefia do Estado, com as matérias relacionadas no artigo 238, 1, primeira parte, 2, 7, 9, 10 e13; (2) Chefia de Governo, com as matérias indicadas nos artigos 238, 2, 3, 4, 5, 6, 8, 11, 12, 13, 14, 15 e 16; (3) Chefia da Administração, com as matérias previstas no artigo 238, 1, segunda parte, 9 .

No sistema paraguaio, a responsabilidade política é do Presidente da República ${ }^{284}$.

No Uruguai, na Constituição de 1997, as atribuições do Presidente da República embora enquadradas, igualmente, nas três funções básicas do Poder Executivo $^{285}$, há a ressalva que o Presidente atua, em todas elas, com a presença do ministro ou ministros responsáveis, nos termos do artigo 149, exercendo o Poder Executivo em atuação com os ministros e o conselho de ministros (art. 168, caput),

\footnotetext{
284 José Luis Simón afirma que "el presidencialismo autoritario que predomina en la historia política del Paraguay hace que algunos autores sostengan que, incluso desde su nacimiento, esta República no conoció la democracia al menos hasta el inicio de la transición en 1989. El Poder Ejecutivo, tradicionalmente predominó frente a los demás poderes $\mathrm{y}$, dependiendo de quien ejerciera la primera magistratura, de hecho también fue el poder fuerte durante la etapa de la Constitución liberal de 1870". (SIMÓN, José Luis. Sistema político, Estado y sociedad en el Paraguay del autoritarismo contemporáneo y en el de la transición y la integración democrática. In: TAVARES, José Antônio Giusti; ROJO, Raúl Enrique (Orgs.). Instituições Políticas Comparadas dos Países do MERCosUL. Rio de Janeiro: Fundação Getúlio Vargas, 1998. p. 403)

${ }^{285}$ Utilizando-se da classificação apresentada por SILVA, José Afonso da. Ob. cit.
} 
são as funções: (1) Chefia do Estado, com as matérias relacionadas no art. 168, 2, 12, 15, 16, 17 e 20; (2) Chefia de Governo, com as matérias indicadas nos art. 168, 1, 3, 4, 5, 6, 7, 8, 9, 10, 11, 18, 19, 21, 22 e 25; (3) Chefia da Administração, com as matérias previstas no art. 168, 13, 14, 23 e 26.

Embora os quatro Estados fundadores do MERCOSUL adotem o sistema presidencialista, são inegáveis as diferenças existentes, hoje, em termos formais, no que tange a interpretação peculiar dada pelos mesmos, ao sistema presidencialista. A questão é saber se os liames destes países que professam a tradição presidencialista constituem condição suficiente para, entre eles, criar um Bloco Econômico para além da união aduaneira. 
PARTE III

\section{A INTEGRAÇÃO COMO POLÍTICA DE GOVERNO}

\section{CONTEXTUALIZAÇÃO}

Criado o MERCOSUL, seus Estados-Partes tiveram que construir, ao longo dos anos subseqüentes, uma série de decisões, resoluções e recomendações para o fortalecimento do Bloco. O cabedal jurídico construído de 1991 a 2008, foi considerável, assim como o aumento e modificação dos órgãos do Bloco. Mais do que uma internalização das normas dentro dos ordenamentos jurídicos internos de cada um dos Estados-Membros, passou a ser necessário uma "conscientização" dos nacionais destes Estados, no sentido de absorver o significado do MERCOSUL, e isto foi, até certo ponto, prejudicado, já que um dos mentores originais do Bloco sofrera o processo de impeachment (Collor de Mello) embora seu sucessor (Itamar Franco) ${ }^{286}$ tenha seguido o cronograma previsto no Tratado de Assunção, com o Protocolo de Ouro Preto. Outro aspecto que dificultou a "conscientização" dos nacionais, ao ponto de alguns considerarem estar o MERCOSUL "morto" foi a sucessão de crises ${ }^{287}$ internacionais, ao longo da década de noventa, sem esquecer-

${ }^{286}$ Itamar Franco adotou o MERCOSUL a certo contragosto, tanto é que em antes da concretização do Protocolo de Ouro Preto, durante a VII Reunião dos Presidentes do Grupo do Rio, realizada em Santiago, Chile, lança a idéia de formação de uma Área de Livre Comércio Sul-Americana (ALCSA) que incluiria os países do MERCOSUL, da Comunidade Andina (CAN) e o Chile.

${ }^{287}$ A primeira grande crise da década ocorre no México, nos anos de 1994 e 1995, repercutindo, sobretudo na América Latina.

Iniciada em 1997, a crise dos Tigres Asiáticos é grave e se propaga pelos principais mercados do mundo em velocidade jamais vista. Até então, os Tigres do Sudoeste asiático, Coréia do Sul, Taiwan, Cingapura, Tailândia, Indonésia, Malásia e Hong Kong eram considerados exemplos de desenvolvimento, porém, a recessão japonesa e os problemas estruturais de cada um desses países, possibilitaram violentos ataques especulativos, provocando a evasão de capitais e uma desvalorização das moedas. 
se do projeto $A L C A^{288}$. Para fazer frente a esse crescente turbilhão econômico, Brasil e Argentina socorrem-se do $\mathrm{FMI}^{289}$.

Esses fatos fizeram com que o MERCOSUL fosse deixado em segundo plano, pelos governantes. Seriam necessários oito anos, para que ele fosse, mesmo que simbolicamente, relançado, já no segundo governo de Fernando Henrique Cardoso.

Mas, mesmo com o "relançamento" do MERCOSUL, suas decisões continuaram dentro da órbita do consenso, dependendo da vontade de cada Estado, vontades estas, exteriorizadas por seus Chefes de Estado, e de Governo. As ações e pensamentos dos Presidentes da República dos Estados-Partes espelharam fielmente o compasso na qual o Bloco se construía.

A necessidade destes se equilibrarem entre os interesses nacionais e o interesse do Bloco foram e são constantemente conflitantes, tornando-se necessário

Em 1998, chega a vez da Federação Russa. Com a economia à beira do colapso, o País declara moratória da dívida externa das empresas privadas (estimada em 40 bilhões de dólares) e adia o pagamento de 32 bilhões de dólares em títulos vincendos, provocando uma dramática reação a esse anúncio. Desvaloriza-se o rublo em $75 \%$, e a inflação retorna, juntamente com o registro de quedas recordes nas bolsas mundiais.

No Brasil, também ocorre a desvalorização da moeda, conseqüência da redução das reservas internacionais do País a partir de setembro de 1998, decorrência direta da falência russa, feita de modo unilateral, com isso, afeta seu segundo maior parceiro comercial, a Argentina, que tem o peso atrelado ao dólar em sistema de paridade, fato que, somado aos problemas estruturais da economia, termina por gerar uma enorme crise naquele País.

${ }^{288}$ Realizada em Miami, de 9 a 11 de dezembro de 1994, através do presidente Bill Clinton, com sua justificativa pautada no esforço de unir as economias do Hemisfério Ocidental em uma única área de livre-comércio, Chefes de Estado e de Governo de 34 democracias da região decidiram construir a chamada Área de Livre Comércio das Américas, (Alca), com previsão da eliminação progressiva das barreiras ao comércio e aos investimentos. Os líderes comprometeram-se e concluir as respectivas negociações até o ano de 2005. As suas decisões constam da Declaração de Princípios e do Plano de Ação, aprovados na ocasião.

${ }^{289}$ Fundo Monetário Internacional. Hoje, o FMI trata dos problemas estruturais da balança de pagamento e ao fornecimento de capitais aos países em dificuldades. Ricardo Seitenfus aduz "que o aval do Fundo concedido a um país em desenvolvimento representa, também, um sinal à comunidade financeira internacional sobre a solidez da política financeira adotada. As dívidas externas podem ser negociadas em melhores termos caso o FMI aprove as contas públicas dos devedores". (SEITENFUS, Ricardo. Manual das Relações Internacionais. 2. ed. Porto Alegre: Livraria do Advogado, 2000. p. 155) 
fazer uma análise das interferências políticas dos Presidentes, dentro das decisões do MERCOSUL, bem como os mecanismos a serem suplantados, para criar um mercado comum. 


\section{CAPÍTULO V}

\section{A INTERFERÊNCIA DO SISTEMA PRESIDENCIALISTA NAS DECISÕES DE UM MERCADO COMUM PARA O MERCOSUL}

Considerando-se que todos os Estados-Membros do MERCOSUL adotam o sistema presidencialista, o desenvolvimento do Bloco se faz pela direta interferência dos Presidentes dos países partícipes.

E é em razão disto, que o Tratado de Assunção teve um caráter extremamente simplista, quando de sua concepção, ao tratar matéria de tamanha relevância, que é a integração entre os povos.

A considerável legislação criada pelos órgãos do MERCOSUL, que criam seu direito derivado, ainda não dá escopo a uma supranacionalidade ${ }^{290}$.

Oportuna a observação de Deisy Ventura, quando ressalta: "o direito derivado no MERCOSUL confunde-se com as próprias ordens jurídicas nacionais, naquilo que os Estados entenderem por bem incorporar, entre as decisões dos órgãos comuns ${ }^{291 "}$.

Era da vontade dos membros do MERCOSUL a criação de uma instituição

\footnotetext{
${ }^{290}$ Wagner D'Angelis (ob. cit., p. 80) argumenta que tomando-se a "ordem comunitária como resultado do duplo fenômeno da autonomia e da hierarquização, fica patente a inexistência do direito comunitário no MERCOSUL, havendo quando muito um direito de integração. Não há supranacionalidade no modelo platino. Sua estrutura institucional se reveste de caráter intergovernamental, seus órgãos decisórios não passam de extensão do pensamento e dos interesses dos respectivos governos dos Estados-Partes, e as normas que redundam da organização internacional - sejam de fontes originárias ou derivadas -, excetuadas as de natureza administrativa, precisam ser introduzidas no sistema jurídico nacional de cada país-membro por meio de sua homologação pelo Poder Legislativo e posterior ratificação do Executivo".

${ }^{291}$ VENTURA, Deisy de Freitas Lima. A ordem jurídica do MERCOSUL. Porto Alegre: Livraria do Advogado, 1996. p. 60.
} 
internacional ${ }^{292}$, aplicando-se a regra da unanimidade para exprimir a vontade comum, coincidente com a vontade nacional ${ }^{293}$.

O órgão superior do MERCOSUL e de capacidade decisória, como já exaustivamente visto, é o Conselho do Mercado Comum ${ }^{294}$, integrado, de ordinário, pelos Ministros das Relações Exteriores e da Economia, com reuniões marcadas, sempre que necessário e, pelo menos, duas vezes por ano, na presença dos Presidentes da República dos quatro países. Não há supranacionalidade ${ }^{295}$ no âmbito do MERCOSUL.

Na Constituição, como já analisado no Capítulo IV, desses países ${ }^{296}$, os ministros são alçados à condição de auxiliares do Presidente da República, respondendo diretamente por ele. Questão pertinente, se considerarmos que o

${ }^{292}$ Não deixa de ser sintomática a declaração de Fernando Henrique Cardoso em 28.06.2001 aos integrantes do Conselho de Empresários da América Latina, de que o MERCOSUL deve começar a organizar instituições supranacionais. Tal declaração aponta para uma convergência com a posição Argentina e da União Européia, ambas insistindo na necessidade de maior institucionalização do bloco econômico. Esta declaração de Fernando Henrique marca uma mudança na orientação do Brasil, já que o Itamaraty até então se opunha a idéia.

${ }^{293}$ Ricardo Seitenfus e Deisy Ventura discorrem que "obstáculos de ordem constitucional verificados no Brasil e no Uruguai, impedem a adoção da supranacionalidade no âmbito do MERCOSUL. Não parece, de todo modo, ser esta uma aspiração dos governos dos Estados-Partes, que preferem manter uma grande margem de discricionariedade em suas condutas. Neste sentido, a proposição de uma moeda única no âmbito do MERCOSUL, embora seja proposta de forma séria pelos técnicos que nela acreditam, torna-se patética na fala de governos que não asseguram sequer uma política comercial comum, quanto mais os intensos compromissos de uma política monetária partilhada". (SEITENFUS, Ricardo; VENTURA, Deisy. Introdução ao Direito Internacional Público. Porto Alegre: Livraria do Advogado, 1999. p. 199)

${ }^{294} \mathrm{O}$ art. $3^{\circ}$ do Protocolo de Ouro Preto define o Conselho do Mercado Comum como o órgão superior do MERCOSUL, ao qual incumbe a condução política do processo de integração e a tomada de decisões para assegurar o cumprimento dos objetivos estabelecidos pelo Tratado de Assunção e para lograr a constituição final do mercado comum.

295 Odete Maria de Oliveira (União Européia, p. 68) sustenta que "a noção de supranacionalidade reside na acumulação de determinadas características, como de transferência do exercício de soberania, de forma permanente, por parte dos Estados-Membros à organização da Comunidade. Tal instituto implica, por conseqüência, na criação de um poder efetivo, em virtude da força jurídica de suas decisões, incidência material de suas intervenções tanto em relação ao âmbito de atividades como de destinatários das decisões e, finalmente, face às relações diretas entre os órgãos da Comunidade e os particulares. E à p. 70, complemente que os pressupostos definidores da noção de supranacionalidade podem ser reunidos em três pilares fundamentais: a) transferência de competências; b) exercício independente destas competências: c) aplicabilidade direta e imediata do ordenamento comunitário aos seus destinatários públicos ou particulares".

${ }^{296}$ Por exemplo, o art. 84, I, da Constituição brasileira. 
Presidente ${ }^{297}$, em sua atuação perante a esfera internacional, encontra-se investido da condição de Chefe de Estado, e como tal, dotado de irresponsabilidade política ${ }^{298}$, já que expressa a nacionalidade. Em outras palavras, o MERCOSUL sempre dependeu da vontade e do poder unipessoal dos presidentes de seus EstadosMembros.

Dividindo-se a história do MERCOSUL em duas fases, verifica-se que houve um comprometimento dos governantes na fase de implantação do bloco (19911994), com aumento significativo do comércio intra-Bloco ${ }^{299}$.

Com a criação da Tarifa Externa Comum, dentro de um contexto de uma União Aduaneira, em 1995, uma nova fase se instaura. Consideráveis avanços em direção a União Aduaneira foram realizados, com a criação de um nada desprezível arcabouço jurídico, apesar dos conflitos entre os governos, como é natural, mormente da Argentina e do Brasil se sucederem ${ }^{300}$, ao ponto, em um dado

${ }^{297}$ Raúl Enrique Rojo ressalta, de modo bem claro que "la institución más importante de la República Argentina es el presidente. Esta situación relevante se manifiesta en dos esferas: por un lado en el avance considerable de los poderes presidenciales a costa de los del Congreso. Por outro, en cierto aspecto que excede largamente la mera ampliación de competencias, a saber: en la conversión del presidente en conductor político del pueblo argenino, pues el significado político de su gestión no será juzgado únicamente en función de las medidas llevadas a cabo po él, sino más bien por el interés y los impulsos que haya sido capaz de despertar en su pueblo". (ROJO, Raúl Enrique. In: TAVARES, José Antônio Giusti; ROJO, Raúl Enrique (Orgs.). Instituições Políticas Comparadas dos Países do MERCosUL. Rio de Janeiro: Fundação Getúlio Vargas, 1998. p. 95). José Luis Simón segue a mesma orientação ao afirmar "el presidencialismo autoritario que predomina en la historia política del Paraguay hace que algunos autores sostengan que, incluso desde su nacimiento, esta República no conoció la democracia al menos hasta el inicio de la transición en 1989. El Poder Ejecutivo, tradicionalmente predominó frente a los demás poderes y, dependiendo de quien ejerciera la primera magistratura, de hecho también fue el poder fuerte durante la etapa de la Constitución liberal de 1870". (SIMÓN, José Luis Sistema político, Estado y sociedad en el Paraguay del autoritarismo contemporáneo y en el de la transición y la integración democrática. In: TAVARES, José Antônio Giusti; ROJO, Raúl Enrique (Orgs.). Instituições Políticas Comparadas dos Países do MERcosul Rio de Janeiro: Fundação Getúlio Vargas, 1998. p. 403)

${ }^{298}$ Já que encarna a unidade do Estado, a nacionalidade. O Presidente, quando no exterior, por exemplo, representa a todos os súditos, independentemente de ideologias e, nesta condição, está acima das responsabilidades das políticas de governo, do programa de governo.

${ }^{299}$ Como visto no Capítulo I.

${ }^{300}$ A este respeito ver: ALMEIDA, Paulo Roberto. Trajetória do MERCOSUL em sua primeira década (1991-2001: uma avaliação política a partir do Brasil). In: PIMENTEL, Otávio Luiz (Org.). Direito da Integração - Estudos em homenagem a Werter R. Faria. Curitiba: Juruá, 2001. v. II. Paulo 
momento, de, virtualmente, haver uma quase paralisia do Bloco, embora

\author{
poderosamente influenciada por fatores externos ${ }^{301}$.
}

Roberto Almeida (p. 314-315), analisando a TEC sustenta "que a TEC se apresenta como uma estrutura racional em termos econômicos, comportando em seu regime normal um leque de dispersão relativamente reduzido (de 0 a 20\%), que esposou características da própria tarifa aduaneira brasileira - compreensivelmente o país de maior relevância para o comércio intera e extra-regional. Sob o impacto da crise financeira asiática e em vista os problemas decorrentes do choque de competitividade externo tanto sobre o Brasil quanto a Argentina, a TEC foi objeto de revisão em dezembro de 1997, procedendo-se, por meio de acordo quadripartite, a um aumento linear de 3 pontos nas alíquotas efetivas, o que representou um aumento de $25 \%$ na tarifa média de $14 \%$ aplicada geralmente pelos países membros. Durante a reunião do Conselho do Mercado Comum (Florianópolis, 14 e 15.12.2000), os Estados Partes alegaram necessidades fiscais para não procederem à redução integral do aumento transitório da TEC. Nessa ocasião, foi acordada a redução dos níveis tarifários adicionais para 2,5 pontos percentuais, com o compromisso de estabelecer novas reduções de acordo com cronograma a ser definido até 30 de junho de 2001. Em fevereiro de 2001, contudo, o novo ministro da economia da Argentina, Domingo Cavallo, assumiu em atmosfera de crise, prometendo revitalizar a economia de seu país: sua primeira providência foi a de suspender unilateralmente a vigência da TEC para um certo número de produtos, fixando novas tarifas para dois grupos de importações (basicamente 35\% para bens de consumo corrente, como forma de proteger temporariamente indústrias argentinas ameaçadas, e zero para bens de capital, de maneira a estimular-lhes a competitividade). Muito embora reunião extraordinária do MERCOSUL, em abril de 2001, tenha ratificado essas mudanças e acolhido as 'exceções temporárias' acordadas à Argentina, essa nova realidade, mais as sucessivas declarações do ministro Cavallo no sentido de fazer o MERCOSUL retroceder a um status de simples zona de livre-comércio, contribuíram para agravar a situação de crise política vivida pelo bloco desde a desvalorização brasileira de janeiro de 1999 e para criar uma impressão internacional de 'inviabilidade' do projeto de mercado comum em face de pressões externas tão relevantes como a criada com as negociações da Alca. A TEC deveria ter sido complementada por uma política comercial conjunta dos países membros em relação a terceiros países, mas diversos elementos dessa política permaneceram carentes de uma definição, como no caso dos incentivos fiscais. Durante a fase de transição, houve consenso de que se deveriam identificar os casos de política industrial ou fiscal suscetíveis de representar subsídios ou vantagens indevidas para qualquer dos membros, em vista de sua harmonização ulterior, com vistas a evitar distorções comerciais na região. A despeito de esforços conduzidos na fase subseqüente, não houve contudo acordo nesse sentido, o que aliás gerou polêmicas internas relativas a regimes especiais concedidos ao setor automobilístico no Brasil e na Argentina. O Brasil considera que o desmantelamento de sua política de incentivos fiscais e creditícios, como por exemplo os programas promovidos pelo BNDES, vincula-se estreitamente ao correspondente desmantelamento da aplicação unilateral e abusiva de direitos antidumping e medidas compensatórias no comércio intrazona. A consolidação de uma união aduaneira perde sentido se não forem criados mecanismos e disciplinas comuns nessas duas áreas. No mesmo sentido, o tema da coordenação das paridades cambiais, importante em vista de suas repercussões imediatas nas correntes de comércio e nos fluxos de capitais, foi objeto de estudos aprofundados, a partir de uma análise dos regimes cambiais nacionais existentes e do papel, na definição das paridades recíprocas, do intercâmbio intra e extrazona. Não se logrou, contudo, uma definição tendente à adoção de um sistema de bandas convergentes ou mesmo um sistema monetário baseado em paridades fixas, tendo em vista os grandes descompassos observados nos processos de ajuste e de estabilização macroeconômica, praticamente desde o início do MERCOSUL. A Argentina adotou, como se sabe, a partir de maio de 1991 (Plano Cavallo), uma lei de conversibilidade, sustentada numa paridade absoluta entre o peso e o dólar, enquanto o Brasil tardava até 1994 para iniciar seu processo de estabilização (Plano Real), parcialmente sustentado numa âncora cambial".

301 "A despeito da vontade política dos governos dos quatro países membros, fatores de política econômica interna na Argentina e no Brasil (recessão, desemprego, sistemas de câmbio diferentes, processos eleitorais), acoplados às conseqüências das crises financeiras internacionais de fins de 1994 no México, de 1997 na Ásia e de 1998 na Rússia e no próprio Brasil em seguida, causaram sérias dificuldades para a continuada evolução positiva do processo negociador 
Sempre considerando ser o MERCOSUL ainda voltado à intergovernabilidade, e com países que adotam o sistema presidencialista, o fato é que, a partir da implantação da TEC ${ }^{302}$, em 1995, existiram várias decisões para além de uma União Aduaneira (que, como já visto, compreende a livre circulação de bens, capitais e livre concorrência), isto é, voltadas à implantação de um Mercado Comum (que, reiterando, como já visto, além do que contém uma União Aduaneira, propugna uma livre circulação de pessoas e serviços).

Fazendo-se um levantamento, ao longo do período de 1995-2007, das Decisões do CMC, pensadas para além de uma União Aduaneira, tem-se diversas medidas tomadas, que começam pelo Programa de Ação do MERCOSUL até o ano 2000 (Dec. 9/95 CMC), que propugnava como ação visando um Mercado Comum

regional. A desvalorização do real, em janeiro de 1999, e a introdução subseqüente de um regime de flutuação cambial deflagraram uma grave crise político-comercial e de credibilidade externa. $\mathrm{Na}$ esteira da crise da desvalorização, foi criado, em junho de 1999, o Grupo de Trabalho sobre Coordenação de Políticas Macroeconômicas, com vistas a retomar os entendimentos sobre o tema e propor ações tendentes ao aumento da percepção de credibilidade do bloco frente aos investidores internacionais. O exercício quadripartite de coordenação macroeconômica sem dúvida agrega projeção internacional aos programas de estabilidade monetária dos países da região, a despeito das críticas de que foram reduzidos seus resultados concretos e de que os ganhos em termos de credibilidade externa do Brasil se deveram muito mais aos indicadores macroeconômicos alcançados individualmente pelo País do que a qualquer iniciativa ou outro esforço que se possa reputar ao Grupo de Trabalho sobre Coordenação de Políticas Macroeconômicas. É acertado notar, no entanto, que a publicação em outubro de 2000 de indicadores macroeconômicos sobre aspectos fiscais e a antecipação dos prazos previstos para a definição de metas macroeconômicas não foram suficientes, por exemplo, para evitar a atual crise de credibilidade da Argentina nos mercados externos. A desvalorização do real foi igualmente impactante em termos políticos e comerciais, dada a imediata reação do setor privado argentino, logo encampada pelo Governo de Buenos Aires às vésperas da eleição. O receio, que se comprovou infundado, de inundação de produtos brasileiros nos mercados vizinhos ou de fuga de capital para o Brasil reacendeu demandas protecionistas por parte de setores de menor competitividade naquele país. Foi possível perceber-se a magnitude do problema, de toda forma, pela queda inédita no volume do intercâmbio intra-MERCOSUL, com a redução do saldo comercial até então acumulado pela Argentina contra o Brasil. No ano seguinte, porém, os fluxos de comércio já tinham retomado os valores anteriores à crise, mas subsistiam os problemas de competitividade argentina vinculados em parte a seu regime cambial rígido". (ALMEIDA, Paulo Roberto. Ob. cit., p. 316)

${ }^{302}$ Ainda sobre esse assunto, lembra Paulo Roberto Almeida (ob. cit. p. 317) que na negociação da Tarifa Externa Comum (TEC) no MERCOSUL, as "diferenças de estrutura e de níveis de desenvolvimento industrial entre o Brasil e os demais parceiros resultam na aceitação, durante uma 'fase de convergência' (até 2001-2006), de listas nacionais de exclusão (para bens informáticos e de capital, por exemplo). Os países-membros também decidem harmonizar os incentivos às exportações, respeitando disposições do GATT". 
atuando nas áreas de agricultura, Indústria, minérios, energia, serviços, comunicações, transporte e infra-estrutura, turismo, assuntos financeiros e tributários

e políticas macroeconômicas ${ }^{303}$. Ainda em 1995, há a Dec. 4/95 CMC, depois

${ }^{303}$ Os propósitos nestes setores eram: "1. La marcha hacia el Mercado Común. 1.1 Agricultura. Se crearán en el ámbito del MERCOSUR las condiciones adecuadas para incrementar en la región la productividad de la agricultura, desarrollando su progreso tecnológico y asegurando el desarrollo racional de la producción a partir de la libre circulación de los productos agrícolas y agroindustriales y la coordinación de las acciones e instrumentos de las correspondientes políticas nacionales, inclusive en materia de abastecimiento alimentario regional. Se realizará el seguimiento y análisis de las políticas agrícolas y agroindustriales nacionales inclusive en lo que se refiere a la ayuda interna a la agricultura, teniendo como referencia el Acuerdo Agrícola aprobado durante la Ronda Uruguay del GATT. Tomando en cuenta que la agricultura constituye un sector íntimamente ligado al conjunto de la economía de los Estados Partes, será también un objetivo prioritario el potenciamiento de la agricultura del MERCOSUR en su inserción internacional. 1.2 Industria. El objetivo es la creación de un ambiente favorable a la reestructuración y a la consiguiente mejora de la competitividad del conjunto de las industrias de la región. Dicho proceso de reestructuración deberá evolucionar gradualmente hacia el crecimiento de la capacidad de producción y de innovación tecnológica, como factores esenciales para la competitividad y la inserción ventajosa en la economía internacional. Se estimulará la cooperación industrial, la formación de cadenas tecnológicas, la especialización industrial, las alianzas estratégicas que potencien la utilización del mercado ampliado y la promoción de micro, pequeñas y medianas empresas. 1.3 Minería. Se promoverán acciones con vista a la identificación de oportunidades de cooperación e intercambio de tecnología, de modo de promover el desarrollo de la producción minera regional. 1.4 Energía. Los objetivos para el año 2000 en el MERCOSUR serán entre otros: La optimización de la producción y del uso de las fuentes de energía de la región. La promoción del uso racional de energía y su conservación. La promoción de la producción y uso de energías renovables con bases económicas y ambientales sustentables. La armonización de la legislación ambiental y establecimiento de estructuras organizacionales que permitan resultados equivalentes en la mitigación de los impactos sobre el medio ambiente, resultantes de la producción, transporte, almacenamiento y uso de los energéticos. 1.5 Servicios. En la nueva etapa de profundización del proceso de integración, debe progresarse hacia la liberalización del comercio de servicios a nivel del MERCOSUR, teniendo en cuenta el Art. $1^{\circ}$ del Tratado de Asunción. El objetivo inicial es lograr un Acuerdo Marco sobre Comercio de Servicios de MERCOSUR de conformidad con el Acuerdo General sobre Comercio de Servicios de la OMC. En el ámbito de las relaciones externas, los Estados Partes del MERCOSUR coordinarán su posición en las negociaciones sobre comercio de servicios actuales y futuras que se desarrollen. 1.6 Comunicaciones. Las principales líneas de acción son: - promover acciones conjuntas en temas referidos a las telecomunicaciones y los asuntos postales; - analizar la posibilidad de compatibilizar los planes de implementación de nuevos servicios y nuevas tecnologías; - explorar la posibilidad de realizar programas comunes de proyectos de desarrollo; - crear sistemas y medios que posibiliten el intercambio de información; - examinar la posibilidad de armonizar los procedimientos de prestación de servicios. 1.7 Transporte e Infraestructura. El objetivo en esta área es que el transporte, en todos sus modos, contribuya al desarrollo pleno del libre comercio intrarregional, así como la inserción eficiente del MERCOSUR en el plano internacional, permitiendo que los ciudadanos y los operadores económicos del MERCOSUR participen plenamente de los beneficios derivados de la creación de la Unión Aduanera. Se deberán asimismo, identificar y promover proyectos de infraestructura que contribuyan al mejoramiento del sistema regional de transporte. 1.8 Turismo. Se enfatizará la coordinación de las políticas de turismo de los Estados Partes para promover el intercambio cultural y de conocimientos, los intercambios comerciales y la generación de puestos de trabajo. 1.9 Asuntos Financieros. La agenda del MERCOSUR hacia el año 2000 abarcará dos tipos de temas: Por un lado están los aspectos sobre los que es posible y deseable alcanzar un entendimiento en plazos relativamente breves. Estos abarcan las áreas del sistema financiero, seguros, mercado de valores, promoción y protección de inversiones, indicadores macroeconómicos y seguimiento de los regímenes cambiarios. También se incluyen el intercambio permanente de información y experiencias en 
substituída pela Dec. 8/96 CMC, que aprovou o Protocolo de Integração Educativa sobre Reconhecimento de Títulos Universitários para o prosseguimento de Estudos de Pós-Graduação nas Universidades dos Países do MERCOSUL, além da Dec. 7/95 CMC, que aprovou o Protocolo de Integração Educativa e Revalidação de Diplomas, Certificados, Títulos e Reconhecimento de Estudos de Nível Médio Técnico. No ano de 1996, há a Dec. 6/99, sobre a Coordenação de Políticas Macroeconômicas. Em 1997, há a Dec. 3/97 CMC, que aprovou o Protocolo de Admissão de Títulos e Graus Universitários para o Exercício de Atividades Acadêmicas nos Estados Partes do MERCOSUL, a Dec. 13/97 CMC, que aprovou o Protocolo de Montevidéu sobre o Comércio de Serviços do MERCOSUL, que já contou com seis rodadas importantes (a última em 2006), complementado em 1998, pela Dec. 9/98 CMC que aprovou o Protocolo de Montevidéu sobre o Comércio de Serviços do MERCOSUL - Anexos com disposições específicas setoriais e listas de compromissos específicos iniciais. Ainda em 1998, a Dec. 16/98, que aprovou o Protocolo de Harmonização de Normas em Matéria de Desenhos Industriais. Em 1999, é criada a Comissão Sócio-Laboral do MERCOSUL pela Res. 15/99 GMC 304 .

materia financiera. El segundo conjunto de aspectos a considerar en el mediano y largo plazo, tiene relación con las negociaciones encaminadas a ampliar el acceso a los mercados financieros. 1.10 Asuntos Tributarios. La consolidación de la Unión Aduanera presupone continuar el examen de las legislaciones tributarias, con el objetivo de identificar asimetrías, a fin de su armonización. 1.11 Políticas Macroeconómicas. Hacia el 2000, el MERCOSUR deberá avanzar en el tratamiento de los problemas económicos coyunturales y de otra índole. Esta estrategia se corresponde con la idea de que la maduración del proceso de integración va a ir acentuando la necesidad de los gobiernos de hacer un examen conjunto de algunas medidas de política económica. Asimismo, un conocimiento más cabal de la coyuntura de los socios va a permitir un mejor diseño de las propias políticas internas. A tales efectos deberá perfeccionarse la elaboración de indicadores macroeconómicos regionales".

${ }^{304}$ Como bem lembra Paulo Roberto Almeida (ob. cit., p. 352), "essa comissão que não tem poder sancionador e funcionará através de recomendações diretas ao GMC, dependerá sobretudo da ação política e da pressão sindical para ampliar o seu papel e transformá-la efetivamente em um espaço de negociação, levando para o GMC as questões sociais". E ressalta um fato significativo que em abril de 1999, "houve a assinatura do primeiro 'Contrato Coletivo de Trabalho no MERCOSUL', entre a Volkswagen do Brasil e da Argentina e os sindicatos dos metalúrgicos destes dois países, estabelecendo os princípios básicos de relacionamento entre capital e trabalho no âmbito do MERCOSUL". 
Em 2000, na esteira do "Relançamento do MERCOSUL", tem-se a Dec. 30/00, sobre a Coordenação Macroeconômica. Em 2005, há a Dec. 23/05, que aprovou o Protocolo Constitutivo do Parlamento do MERCOSUL.

Estas ações têm o condão de trabalhar com medidas que, como anteriormente frisado, vão além da União Aduaneira. O efetivo implemento delas facilitarão, por certo, o objetivo de alcançar o mercado comum. Contudo, alguns obstáculos restam a serem superados para isso, como retratados no Capítulo VI. 


\section{CAPÍTULO VI}

\section{O MERCADO COMUM E O PRESIDENCIALISMO}

Como exposto no primeiro capítulo, o mercado comum contém as características de uma área de livre comércio, que hoje une livre circulação de mercadorias, circulação de capitais, e livre concorrência, mais as características da união aduaneira, onde há uma tarifa externa comum, e acrescida a isso, uma livre circulação de pessoas e, finalmente, uma livre circulação de serviços, havendo aqui uma uniformização da legislação dos Estados-Membros e uma coordenação de políticas macroeconômicas.

O MERCOSUL, embora almeje ser um mercado comum, encontra dificuldades em implementar a condição de união aduaneira, já que esta, como exposto, significa a adoção de uma tarifa externa comum, ou seja, usando de uma lógica reversa, ela atingirá uma das prerrogativas históricas do Poder Executivo, retirando deste, o poder de alterar, através de uma maior ou menor alíquota do imposto de importação ${ }^{305}$, como meio regulador da demanda e a oferta ${ }^{306}$.

${ }^{305}$ Ressaltando que o imposto de importação, o imposto de exportação e a IOF, são, no Brasil, os impostos no qual o Poder Executivo pode alterar as alíquotas dentro do mesmo exercício financeiro.

${ }^{306}$ José Lence Carluci bem demonstra a importância estratégica desse controle ao ressaltar as funções e os efeitos do imposto de importação. Funções do imposto de importação: "1. Função financeira - como receita derivada da arrecadação tributária. 2. Função promocional - os direitos aduaneiros exercem função promocional quando visam encarecer de tal forma as mercadorias estrangeiras importadas, que induzem internamente os empresários nacionais a efetuar inversões de capital na produção de tais mercadorias. Diz-se que em tais casos, o Imposto de Importação está agindo no sentido do desenvolvimento industrial. Esta e a função protetora constituem os alicerces básicos do processo conhecido como substituição de importações. 3. Função seletora em decorrência de dificuldades no balanço de pagamentos do país, surgem direitos excepcionalmente elevados, com o fim deliberado de restringir certas importações consideradas supérfluas e, dessa forma poupar divisas para cobertura de importações essenciais. a função de impedir a importação de certos produtos é que distingue os direitos seletores do de caráter financeiro. 4. Função protetora - visa favorecer a indústria incipiente, impondo uma tributação adequada, ou seja, até o limite necessário a representar uma proteção à indústria nacional, de custos mais elevados sem que, em contrapartida, essa proteção desestimule a melhoria da produtividade. Principais efeitos: 1 . Balanço de pagamentos - sendo a balança comercial o componente de maior peso relativo no balanço de pagamentos, são evidentes as repercussões 
A rigor, há dificuldades, em termos de MERCOSUL, para se superar a própria área de livre comércio, no que diz respeito à livre circulação de mercadorias $^{307}$.

Outro aspecto relevante: quando o MERCOSUL se tornou uma União Aduaneira, foi que os produtos originários de terceiros países aqui passaram a ingressar, não importa em qual porto, com uma mesma tarifa. Isso desnudou um velho problema: a diferença de taxas, mas principalmente de custos, entre os portos.

Com a TEC, o Brasil, temendo que seus portos perdessem, em termos de custos, para os portos da Argentina e do Uruguai, tomaram algumas providências de modo a tornar mais competitivos seus portos brasileiros.

E o novo modelo portuário brasileiro, sob o ponto de vista de um elo de cadeia logística de transporte, teve como base jurídica a Lei 8.078/90 (Cód. de Defesa do Consumidor). A partir daí, várias leis foram implementadas, de modo que os portos brasileiros são afetados pelo seguinte ordenamento jurídico:

A Lei do Portos - Lei 8.630/93.

Lei das Licitações - Lei 8.666/93 e 8.883/94.

nessa área de um maior ou menor controle das importações. 2. Efeito consumo - a introdução de uma Tarifa, ao aumentar o preço, tenderá a reduzir o consumo total. 3. Efeito de redistribuição - 0 livre-cambismo favorece os monopólios, ao passo que a Tarifa protege os países de economia pobre relativa. 4. Efeito emprego - pressupõe-se que, ao elevar o preço do produto importado, parte da demanda se deslocará para o similar nacional, ou seja, declínio da importação com o aumento da produção e renda nacional". (CARLUCI, José Lence. Uma Introdução ao Direito Aduaneiro. São Paulo: Aduaneiras, 1997. p. 75-77)

${ }^{307}$ A Decisão $4901 \mathrm{GMC}$, em um passo ainda tímido, nominou os pontos de fronteira de controle integrado, derrogando a Decisão 43/97 GMC. Alejandro Grimsom salienta que, "por um lado, a alfândega aparece trabalhando em diversas formas de inter-relação, tanto no nível comercial como populacional. No caso do MERCOSUL, o discurso federal de 'integração' envolve e favorece apenas às grandes empresas e não melhora a situação da população da fronteira. O problema em questão - dificuldade de construção de redes de relações e vínculos - abarca diversas esferas, contudo a causa principal que se apresenta em algumas narrações restringe-se à alfândega. Em outras histórias, esta instituição irradia o conflito para outras relações sociais". (GRIMSOM, Alejandro. Vivências do Estado como alteridade. In: FRIGERIO, Alejandro; RIBEIRO, Gustavo Lins (Orgs.). Argentinos e Brasileiros. Petrópolis: Vozes, 2002. p. 170) 
Lei de Defesa da Concorrência - Lei 8.884/84.

Lei de Concessão - Lei 8.987/95 e 9.074/95.

Lei de Delegação - Lei 9.277/96.

Lei de Desestatização - Lei 9.491/97.

A lei dos portos teve uma vacatio legis de cinco anos para entrar em vigor. Não houve, como se pode supor, na maioria dos portos brasileiros, um adequado preparo para a nova lei. O resultado foi inevitável, com a literal destruição do OGMO ${ }^{308}$ de vários portos.

A resistência aos novos conceitos desta lei também atingiu a alguns dos governos estaduais que se recusaram (e se recusam) em abrir mão de suas prerrogativas, mas que não têm dinheiro para a modernização da infra-estrutura portuária.

A falta de recursos para os portos leva ao seguinte paradoxo: com o volume de exportação/importação existente, se todas as infra-estruturas de transportes rodoviário e ferroviário estivessem em boa ordem, a estrutura portuária entraria em colapso.

Na Argentina, também houve problemas semelhantes ${ }^{309}$.

${ }^{308}$ Órgão Gestor de Mão-de-Obra Portuária, que passou a centralizar e substituir os sindicatos como contato junto aos importadores, exportadores e armadores adotando o conceito de multifuncionalidade. Esse conceito racionalizou o uso de portuários, barateando, em tese, alguns dos custos portuários.

${ }^{309}$ A lei que regula os portos argentinos é a Lei 24.093, também de 1993. Sobre ela, ZUIDWIJK, Antonio, disponível em: <http://ahorainfo.com.ar/?p=6265>, acesso em: 08 fev. 2008. O especialista em temas portuários e marítimos assim se manifesta: "Hace quince años, se promulgaba la Ley de Actividades Portuarias № 24.093. La norma, de solo 23 artículos, generó un cambio total en el régimen portuario argentino. Se devolvieron en forma gratuita todos los puertos a las provincias, y el Estado Nacional desaparece como propietario, administrador y operador de esas terminales. Se crean las figuras de los puertos industriales, particulares de propiedad y uso privado comercial y la posibilidad de su fraccionamiento en unidades especializadas. La 
O fato é que, a tradição presidencialista, no âmbito do MERCOSUL, como demonstrado no quarto capítulo, induz a práticas populistas e clientelistas. Abdicar do controle aduaneiro e, conseqüentemente, do imposto de importação com suas funções e efeitos é ceder um espaço que talvez os governantes ainda não estejam em condições de assumir.

Em termos de MERCOSUL, a implementação, tanto da área de livre comércio, como de união aduaneira, ainda encontram dificuldades. Um exemplo simples, porém eficaz, foi a maxidesvalorização da moeda brasileira, sem consulta aos demais sócios, e por vontade única de seu governante, provocando uma séria crise na Argentina e isto foi feito com o amparo Constitucional.

Mas, indo além, já que o MERCOSUL se propõe a ser um mercado comum, na órbita deste, ainda há duas liberdades que merecem uma maior atenção: livre circulação de pessoas, com a criação de um passaporte comum e a livre circulação de serviços.

Pensando-se em termos de MERCOSUL, no que concerne à livre circulação de pessoas não haveria maiores empecilhos, já que, em todas as Constituições dos Estados-Membros, são assegurados aos estrangeiros, nos termos da lei, os mesmos direitos que os nacionais.

O problema se encontra na livre circulação de serviços. Por ela, qualquer cidadão do bloco tem o direito de exercer livremente sua profissão, em qualquer país do bloco, em igualdade de condições com os nacionais; e para tanto, serão necessários uma harmonização das legislações educacionais, com o estabelecimento de uma grade curricular mínima comum. Até aí, nada de 
conflituoso. A questão se modifica no aspecto de como garantir esse direito de exercício. Como os Estados não admitiriam a ingerência de outros Estados em seus assuntos internos, seria necessário criar um órgão comum que fiscalizasse o cumprimento desse direito. Fatalmente esse órgão encontraria várias legislações nacionais que colidiriam com o princípio da livre circulação de serviços, e o Estado nacional teria que modificar sua lei, muitas vezes, a contragosto. Aqui não vigora mais a regra do consenso, e sim, a da maioria e, nesta condição, as normas não seriam mais intergovernamentais, na órbita do direito internacional público, e, sim, supranacionais, com normas oriundas do direito comunitário. Eventualmente, o Estado nacional iria querer discutir alguns aspectos de sua lei, e ter-se-ia que criar um Tribunal para o exame das questões comunitárias.

E criar um Tribunal para decidir estas questões implicaria em uma mudança profunda em dois aspectos: o primeiro, seria a admissão que a norma comunitária seria superior à norma nacional; o segundo, é admitir a competência desse Tribunal sobre questões que ocorram dentro do território nacional. Esses dois aspectos colidiriam com a constituição brasileira e uruguaia.

É bem verdade que a implantação de uma livre circulação de serviços acometeria problemas na constituição brasileira e uruguaia, independentemente do sistema político adotado, ou seja, não seria o sistema presidencialista, a priori, de per si, que iria obstaculizar essa implantação, mas, dado o centralismo político que o sistema possui, dificilmente um Presidente poderia aceitar, no exercício de seu mandato, uma perda da parcela de poder que detém ${ }^{310}$.

${ }^{310}$ Sobre este aspecto, significativa foi a frase do discurso de Garibaldi Alves Filho, presidente do Congresso Nacional Brasileiro, na abertura do ano legislativo de 2008, publicado na revista Veja ed. 2.047, de 13.02.2008, p. 48, assim proferida: "não é exagero afirmar que, a cada medida provisória editada sem os critérios de relevância e urgência, a Constituição é rasgada com 
O sistema personalista retratado pelo presidencialismo, no âmbito do MERCOSUL, acaba gerando distorções importantes. O temperamento de alguém que acumula a chefia de estado e de governo influenciará enormemente nas relações com os outros estados soberanos, tornando sua decisão, a priori, a vontade do País.

É evidente, que, em razão do estilo entre os detentores da Chefia de Estado, houve uma considerável mudança de postura, no que concerne ao MERCOSUL, principalmente entre os dois sócios maiores, em decorrência das relações entre Menem e Collor, posteriormente, aquele com Itamar Franco e Fernando Henrique Cardoso e este com Fernando de la Rua, e Duhalde, ou ainda entre Nestor Kirchner e Luis Inácio Lula da Silva e este com Cristina Kirchner. Por outro lado, as queixas dos dois sócios menores, em relação ao comércio inter-regional, não podem ser ignoradas. O arrojo pelo qual se pautara o MERCOSUL, em seus dois primeiros anos, e o ritmo marcado, nos anos subseqüentes, espelham, em maior ou menor grau, a expectativa de seus governantes, aliás, como examinado no Capítulo V.

A real implantação de um mercado comum implica em substanciais modificações de paradigmas, tanto da ótica governamental, quanto da população em geral. O modo de concepção dos órgãos do MERCOSUL dá ao Estado-nação ${ }^{311}$ e a seus governantes, extraordinário poder discricionário.

desprezo. Sob tal pano de fundo, o que se distingue é um Congresso transformado em quarto de despejo de um presidencialismo de matiz absolutista".

${ }^{311}$ Odete Maria de Oliveira discorre que "o conceito clássico de soberania como poder absoluto do Estado-Nação, ou como definida por Panayotis Soldatos (Le systéme institucionnel et politique des Comuninautés Europeénne dans un monde en mutation, Bruxelas, Bruylant, 1989, p. 18), em termos operativos: posse plena da plenitude de competências e do poder público e de seu exercício no interior de um território, de tal forma total, exclusiva e isenta de qualquer intervenção exterior e superior a propósito destas mesmas competências". (OLIVEIRA, Odete Maria de. União Européia: Processos de Integração e Mutação. Curitiba: Juruá, 1999. p. 64) 
Outro aspecto a ser considerado, de cunho histórico, é o temor que sempre

esteve presente quando se fala em integração latino-americana ${ }^{312}$, frente a uma

hegemonia brasileira, em face de sua população e tamanho ${ }^{313}$.

Observando a história da América espanhola, verifica-se sua caracterização

exatamente por movimentos contrários à integração, inversos aos da história da

América portuguesa ${ }^{314}$. Outro fator é o imenso vazio que existe, ao longo de boa

parte das fronteiras, à exceção, é claro, da região platina ${ }^{315}$.

somatório destes fatores, acrescidos de crises econômicas endêmicas,

${ }^{312}$ Carlos Alzamora expõe que "não compreendemos ainda que a negociação do poder político e econômico a nível internacional não passa pelo suplício, nem pela invocação ao altruísmo, mas pela organização de um poder de negociação em conjunto e pela execução de uma estratégia que nos permita empregar esse poder conjunto com eficácia. Enquanto os perigos se amontoam no horizonte latino-americano, nós seguimos paralisados pela falta dessa débil estrutura institucional latino americana, indecisos, talvez, para empunhar nas nossas mãos nossos próprios destinos, e o que é mais grave, impotentes para organizar nossa capacidade de decisão". (ALZAMORA, Carlos. La crisis y la capacidad de acción latinoamericana. Revista de la Integración Latino Americana, $\mathrm{n}$. 105, set. 1985. Apud C. SCHAPOSNIK, Eduardo. As Teorias da Integração e o MERCOSUL Estratégias. Florianópolis: UFSC, 1997. p. 12)

${ }^{313} \mathrm{Ou}$ do expansionismo brasileiro. José Alexandre A. Hage argumenta "que estas características são vistas não apenas no tamanho do território e na capacidade de liderança política na região, mas são igualmente vislumbradas na presença brasileira nas sete fronteiras que o País tem além das existentes com os vizinhos que formam o MERCOSUL. Além disso, teria também de se levar em conta os laços coma região da África Austral, os países de língua portuguesa e com a República Sul-Africana, de grande importância regional para o Brasil poder arregimentar capacidades de um global trader, de uma potência ascendente". (HAGE, José Alexandre A. As Relações Diplomáticas entre Argentina e Brasil no MERCOSUL - princípios de hegemonia, dependência e interesse nacional no Tratado de Assunção. Curitiba: Juruá, 2004. p. 118) Paulo Roberto de Almeida, no mesmo sentido, discorre que "contando com tais peculiaridades inerentes ao Brasil, em sua projeção natural na América do Sul, como se o País fosse o detentor da chave estratégica dos negócios da região no século XXI, mesmo considerando que não há, aparentemente, nenhuma ação diplomática ou militar brasileira que venha a se constituir num 'destino manifesto'. Esta nítida feição hegemônica do Brasil, se dará, ainda mais, se não houver um claro projeto de construção de um espaço econômico feito por todos os membros do MERCOSUL". (ALMEIDA, Paulo Roberto de. O Brasil e o Futuro do MERCOSUL: Dilemas e Opções. In: CASELLA, Paulo et al. (Coords.). MERCOSUL: Integração Regional e Globalização. Rio de Janeiro: Renovar, 2000. p. 24)

${ }^{314}$ LAMBERT, Jacques. Os dois Brasis. São Paulo: Nacional, 1971. p. 33.

315 Jacques Lambert (ob. cit., p. 33) ressalta que "as fronteiras européias, apesar das barreiras econômicas, são linhas em que os povos vizinhos se encontram, mesmo que disso se aproveitem para lutar. Na América do Sul as fronteiras são freqüentemente zonas imensas, fracamente povoadas e às vezes apenas exploradas, em que a penetração é tão difícil que isola os povos uns dos outros, não lhes sendo nem mesmo necessário vigiá-las. Nas fronteiras do Brasil com a Bolívia e sobretudo com a Colômbia e o Peru, o centro do continente, livre de qualquer população sedentária, constitui um vazio em que ainda prevalecem os meios de comunicação primitivos, cuja lentidão, pequena capacidade e preço constituem a mais eficaz das barreiras". 
acaba formando poderosos obstáculos a uma integração, idéia decorrida muito mais

de uma necessidade política dos governos, do que propriamente do apoio popular ${ }^{316}$,

já que o modelo de integração escolhido privilegia a abertura do mercado para

iniciativa privada, a partir de um modelo neoliberal ${ }^{317}$, dentro daquilo que foi chamado

de "Consenso de Washington ${ }^{318 " . ~ U m ~ e x e m p l o ~ e l o q u ̈ e n t e ~ d i s s o ~ e ́ ~ a ~ c r i s e ~ e n t r e ~ a ~}$

${ }^{316}$ Eduardo C. Schaposnik (ob. cit., p. 13) argumenta que "[...] é difícil distinguir quando a falta de apoio se deve a uma diminuição da crença na própria idéia de integração ou quando se trata de um declínio do modelo empregado. O que resulta evidente é que a maior parte das camadas sociais tem julgado pelos efeitos negativos registrados, porque a crise se acentuou, caíram as exportações, também o comércio intra-regional, chegando-se finalmente ao estancamento da economia e ao endividamento vertiginoso, acentuou-se a dependência e se exibiu uma série de fenômenos negativos que fez aflorar um sentimento de ceticismo, afastando até os pensadores sociais e políticos".

${ }^{317}$ As teorias neoliberais podem ser resumidas em cinco metas essenciais: estabilização (de preços e das contas nacionais); privatização (dos meios de produção e das empresas estatais); liberalização (do comércio e dos fluxos de capital); desregulamentação (da atividade privada); austeridade fiscal (restrições aos gastos públicos) (PETRAS, James. No fio da navalha - Os fundamentos do neoliberalismo. 2. ed. São Paulo: Xamã, 1998. p. 18). Perry Anderson sustenta que "se economicamente o neoliberalismo fracassou, socialmente criou sociedades mais desiguais. Mas foi política e ideologicamente onde alcançou os maiores êxitos, disseminando a idéia de que não há alternativas para os seus princípios, que todos, seja confessando ou negando, tem de adaptar-se a suas normas". É o que ele chama de hegemonia. (ANDERSON, Perry. Balanço do Neoliberalismo. In: SADER, E.; GENTILI, P. (Orgs.). Pós-Neoliberalismo: as políticas sociais e o Estado democrático. Rio de Janeiro: Paz e Terra, 1995. p. 23)

${ }^{318}$ Neste particular, é interessante a análise de Otaviano Canuto, em artigo publicado pelo Estado de São Paulo, em 28.07.1998, sobre o assunto, intitulado "O Pós-Consenso de Washington" Passagem de Stiglitz pelo Brasil". O autor lastima a oportunidade perdida de discussão sobre os rumos do desenvolvimento brasileiro e discorre que para Joseph Stiglitz, ex-vice-presidente e ex-economista-chefe do Banco Mundial, "o Consenso se deu em torno de se tomar a liberalização comercial, privatização, ataque à inflação e redução de déficits públicos como um conjunto de remédios necessários à América Latina". Stiglitz, citado por Canuto, salienta que o Consenso "nasceu diante do quadro generalizado de inflação alta e instável, de grandes déficits públicos, de elevados níveis de protecionismo e de visível ineficiência governamental que marcou o continente nos anos oitenta. Mas, prossegue Joseph, que eliminar tais distorções não levam automaticamente ao desenvolvimento. Estacionar na agenda do Consenso pode vir a garantir apenas uma 'paz de cemitério', de estabilidade com estagnação". E, prossegue Stiglitz, "o Consenso deixou de fora outros instrumentos tão importantes quanto aqueles. Não tratou dos mercados financeiros, da concorrência e sua regulação, da transferência de tecnologia e do desenvolvimento de instituições. Partiu do suposto equivocado de que, nas bastaria tirar o governo do caminho para permitir aos mercados funcionarem e o desenvolvimento simplesmente adviria". E mais, continua Stiglitz, "um ponto central diz respeito à relação entre eqüidade e eficiência. Temse hoje em dia crescente consciência de que essas duas qualidades andam juntas, ao contrário do que se pensava na época em que se dizia ser necessário 'esperar o bolo crescer para depois distribuí-lo'". Stiglitz evidenciou, por exemplo, "as enormes ineficiências que aparecem quando há forte desigualdade na riqueza ou na distribuição da propriedade da terra. Grandes desigualdades de renda e riqueza acentuam todos os problemas econômicos derivados das assimetrias de informações". "Mostrou também porque várias experiências de reforma agrária fracassaram por se limitarem à redistribuição de propriedade sem o acompanhamento de políticas de crédito e de assistência técnica que a sustentem. O que é mais importante: apontou para os enormes ganhos quando a experiência de reforma é sustentável." "A 'segunda geração de reformas', pósConsenso, defendida pelo economista parte da premissa de que existem políticas com a capacidade de ampliar tanto a eqüidade quanto o produto. Como no caso da educação. $\mathrm{Na}$ 
Argentina e o Uruguai relativamente às papeleiras ${ }^{319}$.

Criar um Mercado Comum diante de um sistema personalista existente na

cultura e na estrutura dos países do MERCOSUL, e inseri-lo na concepção moderna

de Estado é o grande desafio, já que, para além do presidencialismo, convergem

outras forças que discutem a própria existência do Estado ${ }^{320 / 321}$.

ausência de educação pública, tende a ocorrer um investimento educacional abaixo do ótimo, porque pessoas pobres não podem pagar o custo pleno de sua educação e, certamente, teriam dificuldade de tomar empréstimos com base em seus ganhos futuros." Observou ainda Stiglitz "que um maior apoio público à educação, particularmente quando bem dirigido, pode não apenas aumentar as oportunidades educacionais, melhorando a eqüidade social, como incrementar a eficiência econômica. Assim provou a experiência no Japão, na Coréia do Sul e outros asiáticos onde o investimento pesado em capital humano foi um dos pilares de suas décadas de sucesso". $\mathrm{E}$, finalmente, o terceiro ponto da pauta de reformas abordado foi o da participação dos envolvidos nas políticas públicas como requisito do sucesso destas. "Stiglitz citou pesquisas feitas no Banco Mundial com resultados que mostra ser a questão mais do que discurso retórico ou desejo inocente, tanto no caso de projetos microeconômicos, quanto no nível macro-político."

${ }^{319}$ A questão se refere a uma disputa que a Argentina mantém com o Uruguai relativamente à construção de duas fábricas de celulose. A Corte Internacional de Justiça de Haia (CIJ) em 2006 rejeitou a paralisação cautelar das obras de construção das fábricas.

${ }^{320}$ Kenichi Ohmae apresenta uma questão bastante interessante: "Num mundo onde as fronteiras econômicas estão desaparecendo progressivamente, serão suas fronteiras arbitrárias, historicamente acidentais, realmente significativas em termos econômicos? Em caso negativo, que espécies de fronteira fazem sentido? Em outras palavras, quais são, no fundo, exatamente as unidades de negócios naturais, os agregados de pessoas e de atividades suficientes e de tamanho e escala corretos através das quais deva integrar-se a essa economia?" E, ainda, o mesmo autor, p. XXI, conclui que "os Estados-nações tradicionais tornaram-se unidades de negócios inaturais, até impossíveis, numa economia global. Os Estados-regiões são, de fato, os meios mais eficazes como portas de entrada para a economia global". (OHMAE, Kenichi. O fim do Estado-nação. Rio de Janeiro: Campus: São Paulo: Publifolha, 1999. p. XVIII). Na mesma linha, embora com conclusões finais um pouco diferentes, Jürgen Habermas sustenta que "A economia capitalista, do mesmo modo que a instância estatal burocrática, desenvolveu um sentido sistêmico próprio. Os mercados de bens e de capital e de trabalho obedecem a uma lógica própria, independente das intenções dos sujeitos. E, ao lado do poder administrativo, incorporado nas burocracias estatais, o dinheiro tornou-se um medium anônimo da integração social, cuja eficácia não depende das idéias dos participantes. Essa 'integração sistêmica' entra em concorrência com a 'integração social' mediada pela consciência dos atores, ou seja, com a integração que se dá através de valores, normas e entendimento. A 'integração política', que segue o caminho da cidadania democrática, forma um dos aspectos dessa integração social geral". (HABERMAS, Jürgen. Direito e Democracia - Entre a Factividade e Validade. Rio de Janeiro: Tempo Universitário, 1994. v. II, p. 290)

${ }^{321}$ Corrobora esse entendimento Norberto Bobbio, quando assevera que "tudo corre bem quando os sujeitos da relação são cidadãos do mesmo Estado e a coisa a que se referem pertence ao território desse Estado. Mas e se um dos dois sujeitos é estrangeiro? Se os dois sujeitos pertencem a um Estado, mas a coisa a que se referem se encontra num outro Estado? Bastam essas duas perguntas para nos fazer entender que são infinitos os casos, sobretudo no mundo contemporâneo em que as relações internacionais se vão intensificando, que podem ser resolvidas, conforme se leve em conta a nacionalidade de um ou de outro sujeito, ou a nacionalidade da coisa em relação à dos sujeitos, com normas pertencentes a dois ordenamentos diferentes". (BOBBIO, Norberto. Teoria do Ordenamento Jurídico. 9. ed. Brasília: UnB,1997. p. 179) 
O MERCOSUL, em razão da política dos presidentes que compõem os Estados formadores deste bloco, continua a ser mais um exemplo de cooperação 322 entre os Estados do que, propriamente, uma integração entre eles; posto isto, implicar uma mobilização maior nas áreas comerciais, sociais, culturais, alfandegárias. Não se pode pensar em uma efetiva integração calcada apenas em uma zona de livre comércio.

O presidencialismo, com sua concentração de poderes não permite, por sua própria estrutura, delegação de poderes, sem uma muito próxima fiscalização por parte do Chefe de Estado e de Governo e, com isto, gera desvios importantes que foram analisados no Capítulo IV.

Outro aspecto pouco estudado, mas de enormes repercussões, é que as implicações dentro de um mercado comum perpassam, no âmbito do direito, por uma reconfiguração deste, em todos os seus ramos. Tome-se, por exemplo, o direito civil. Por definição o direito civil é eminentemente territorial, com conceitos precisos relativamente à aquisição da propriedade, do domicílio, do regime de bens do casamento, no que concerne aos requisitos do testamento etc., ou do processo civil onde o que se terão novos recursos a exemplo do que acontece para o ingresso junto ao tribunal de justiça das comunidades européias. Ou ainda, o próprio direito penal, com o surgimento de novos tipos penais e o desaparecimento de outros. Todos eles sofrerão, necessariamente, alargamento de conceitos.

A maior dificuldade de se implantar um mercado comum em um bloco constituído unicamente por Estados que adotam o sistema presidencialista é o fato

\footnotetext{
${ }^{322}$ A cooperação tem por finalidade vantagens mais imediatas dos Estados, especialmente, mas não exclusivamente, na área econômica, sem que aja um aprofundamento na políticas comuns.
} 
de os Chefes de Estado terem que abdicar de uma parcela de seu poder, no exercício de seu mandato, já que, para haver uma verdadeira integração, é conditio sine qua non a adoção de uma política comum, com objetivos comuns e, para tanto, são necessárias constantes adaptações econômicas dos países partícipes, com medidas nem sempre populares. Mudar um programa econômico ou diretrizes econômicas no transcurso de um mesmo mandato, sem uma consulta popular, já que os mandatários foram eleitos em razão, também, de um programa econômico, é um exercício hercúleo com sistema presidencialista, em que antecipar eleições, prática corriqueira, no sistema parlamentar, torna-se golpismo, no sistema presidencialista.

Superado este obstáculo, há ainda mais um, de natureza formal: da necessidade de se modificar a constituição brasileira e uruguaia com a finalidade de permitir-se a existência de um órgão supranacional. A questão pode ser respondida de duas formas. A primeira, pensando-se na natureza das normas comuns, das normas comunitárias colidirem com a essência, com a individualização, com os princípios maiores dos Estados-Partes. A resposta, no presente caso, é obvia necessita-se de uma reforma constitucional.

A segunda, pensar a natureza das normas comunitárias (dentro do contexto da livre circulação de serviços), para não colidirem com os princípios que são a essência dos Estados-Partes. Neste contexto, basta pensá-las como normas de direitos humanos (que na verdade o são, em última análise, já que versam sobre normas comuns ligadas a emprego, saúde etc.), ou ainda, como comparação, que as decisões dentro de um contexto supranacional tenham como resultado (embora de natureza distintos) similar àqueles tomados na esfera de uma $\mathrm{OMC}$, onde, em se verificando a natureza incompatível de uma determinada prática comercial, havendo a condenação, o Estado simplesmente teria que alterar esta legislação. Nesta 
interpretação, não haveria necessidade de sequer modificar-se a Constituição. As

normas seriam aplicadas unicamente dentro do Bloco. Os tratados assinados com

terceiros por este Mercado Comum, continuariam a necessitar a internalização ${ }^{323}$.

${ }^{323}$ Há discordâncias. Deisy Ventura (As Assimetrias, p. 206-207) sustenta "que o poder normativo é partilhado entre o Executivo e o Legislativo no regime presidencialista brasileiro. Assim, a eventual participação do Brasil num órgão supranacional que concentre funções normativas e executivas, não pode ser considerado inconstitucional, tampouco uma inovação, já que a tradição brasileira não corrobora a separação estanque dessas competências. Uma objeção mais sólida reside no equilíbrio entre o Parlamento e a Presidência da República, em relação aos acordos internacionais eventualmente assinados pelo MERCOSUL, quando eles não possuem caráter misto (isto é, quando um acordo é assinado exclusivamente por uma entidade supranacional, sem que os Estados-Membros também sejam signatários da convenção). Tratando-se de acordos internacionais, o art. 49, I da Carta Federal atribui ao Congresso Nacional a competência exclusiva para aprova-los, dado que comportam obrigações para o Estado brasileiro. Além disso, ao outorgar ao Presidente da República competência exclusiva para concluir tratados, convenções e atos internacionais, o art. 84, VIII submete essa competência à aprovação parlamentar. Cabe, então, perguntar se uma futura reforma dos tratados constitutivos, que outorgue verdadeira competência internacional ao MERCOSUL, poderá ser realizada sem que o Brasil proceda a uma reforma constitucional. A resposta parece ser negativa". 


\section{CONCLUSÃO}

O MERCOSUL é um processo em construção, já tendo superado formidáveis barreiras ao longo de sua, ainda curta, existência. E, independentemente da consolidação do mercado comum, já fez história. Todas as tentativas históricas de integração, desde as idéias de Simon Bolívar, com um panamericanismo, passando por uma Associação Latino-Americana, ou, a bem intencionada Associação Latino-Americana de Livre Comércio (ALALC), até chegarse à Associação Latino-Americana de Integração (ALADI), da qual o MERCOSUL seria um de seus sub-blocos, a verdade é que, em termos de volume de comércio, o grau de integração do MERCOSUL já supera a Comunidade Andina de Nações (CAN) ou mesmo qualquer outra tentativa já feita ao longo da história da América do Sul.

Em termos concretos, o MERCOSUL possui um nada desprezível Produto Interno Bruto (PIB) acima de 1 trilhão de dólares (pelos dados preliminares do Banco Mundial, em 2007, somando-se o PIB de seus Estados-Membros seria, mais precisamente, 1 trilhão, seiscentos e quarenta e seis bilhões e quarenta e três milhões de dólares e população superior a 230 milhões de pessoas), tornando-se um atraente e peculiar bloco e mercado. Atraente em razão de sua força econômica e mercado de consumo. Peculiar, em razão de ser o único Bloco Econômico em que todos os seus integrantes adotam um mesmo sistema: o presidencialismo. E esta peculiaridade é extensível aos Estados que Ihe são associados: Chile, Bolívia, Equador, Colômbia e Peru. 
É mais um grande desafio (dos muitos) o MERCOSUL se tornar um mercado comum dentro de um sistema presidencialista e que foi o mote para esta tese.

Ao longo deste trabalho, foram construídos os mecanismos para tornar possíveis as respostas propostas quando da introdução, quais sejam: pode o MERCOSUL vir a se tornar um mercado comum dentro de um sistema presidencialista? E, implantado o mercado comum, como este pode existir dentro de um bloco que adota unicamente o sistema presidencialista?

Para se poder formular as repostas, tornou-se necessária uma contextualização, onde se explicou a origem e a natureza dos blocos econômicos em geral e do MERCOSUL em particular, procurando-se detalhar a estrutura e a evolução deste Bloco.

Feita esta análise, o passo seguinte foi trabalhar o sistema presidencialista presente nos Estados-Membros originários do Bloco, com suas características e peculiaridades.

O terceiro passo foi a reunião dessas duas estruturas e, nesta situação, foi possível responder à primeira questão proposta afirmativamente, desde que superadas as dificuldades relativas à própria essência do poder unipessoal de alguém que foi eleito por seu plano de governo e que é também chefe de Estado. Uma segunda dificuldade seria a profunda alteração de conceitos jurídicos e a terceira, óbices nas Constituições brasileira e uruguaia, já que nestas não há a previsão da supranacionalidade. A alternativa apresentada como visto, e agora reiterado, para tornar possível o mercado comum, está calcada na contextualização da norma comunitária, qual seja, compará-la, em ternos de efeitos e não de natureza, às decisões tomadas na esfera de uma $\mathrm{OMC}$, onde, em se verificando a 
natureza incompatível de uma determinada prática comercial, havendo a condenação, o Estado simplesmente teria que alterar esta legislação. Nesta interpretação, não haveria necessidade de sequer modificar-se a Constituição. As normas seriam aplicadas unicamente dentro do Bloco. Já os tratados assinados com terceiros por este Mercado Comum continuariam a necessitar a internalização da parte do Estado-Membro.

Resta, portanto, a segunda questão: implantado o mercado comum, como este pode existir dentro de um bloco que adota unicamente o sistema presidencialista? Este aspecto demanda um processo de educação política na qual, o modelo europeu, embora substancialmente diferente, pode servir como uma base, já que lá os Estados Nacionais mantêm consideráveis atributos do poder soberano. A resposta parece centrar-se no aspecto da jurisdição. Haverá normas de natureza comunitária e normas de competência privativa do Estado, que são necessariamente diferentes daquelas. Aspectos ligados à administração pública, forças armadas, reconhecimento de novos governos e novos Estados continuarão a ser atribuições do Estado-Nação, dentro de um mercado comum. O poder unipessoal dos Presidentes continuará a ser um dos fatores decisivos a influenciar as relações dentro do bloco, contudo, a opinião pública e o Parlamento serão novas forças presentes, possibilitando um modelo mais equilibrado dentro das relações de poder. 


\section{REFERÊNCIAS}

\section{Obras}

ABELLA, Gonzalo. Historia diferente del Uruguay. 4. ed. Montevideo: Betun San ediciones, 2007.

ACCIOLY, Elisabeth Pinto de Almeida. MERCOSUL \& União Européia - Estrutura Jurídico Institucional. Curitiba: Juruá, 1999.

ACCIOLY, Hildebrando. Manual de Direito Internacional Público. 12. ed. São Paulo: Saraiva, 1996.

ACKERMAN, Bruce. Nós, o Povo Soberano - Fundamentos do Direito Constitucional. Belo Horizonte: Del Rey, 2006.

ALBERDI, Juan Bautista. Fundamentos da Organização Política da Argentina. Campinas: Unicamp, 1994.

ALMEIDA, Paulo Renan de. Pacto ABC - Raízes do MERCosUL. Porto Alegre: EDIPUCRS, 1998.

AMORIM NETO, Octavio. Presidencialismo e Governabilidade nas Américas. Rio de Janeiro: FGV, 2006.

ANDERSON, Perry. Linhagens do Estado Absolutista. São Paulo: Brasiliense, 1985.

ANDRADE, Manoel Correia de. A Revolução de 30 - Da República Velha ao Estado Novo. Porto Alegre: Mercado Aberto, 1988. 
ARINOS, Afonso; QUADROS, Jânio. História do Povo Brasileiro. 2. ed. São Paulo: J. Quadros Ed. Culturais, 1968.

ARON, R. Paz e Guerra Entre as Nações. Clássicos IPRI. Brasília: UnB, 2002.

ARTEAGA, Juan José. URUGUAY - Breve Historia contemporânea. Cidade do México: Fondo de Cultura Económica, 2000.

AZAMBUJA, Darcy. Teoria Geral do Estado. Porto Alegre: Globo, 1977.

BALASSA, Bela. Teoria da Integração Econômica. Lisboa, 1972.

BATISTA, Luiz Olavo. O MERCOSUL, suas instituições e ordenamento jurídico. São Paulo: LTr., 1998.

BAPTISTA, Luiz Olavo; MERCADANTE, Araminta de Azevedo. MERCosUL - Das Negociações a Implantação. São Paulo: LTr, 1994.

BEIRED, José Luis Bendicho. Breve História da Argentina. São Paulo: Ática, 1996.

BELLO, José Maria. História da República. 8. ed. São Paulo: Nacional, 1983.

BLIN, Arnaud. La Paix de Westphalie ou la naissance de l'Europe politique moderne. Editions Complexe, 2006.

BOBBIO, Norberto. Estado Governo Sociedade - para uma teoria geral da política. 4. ed. São Paulo: Paz e Terra, 1995.

A Teoria das Formas de Governo. 8. ed. Brasília: UnB, 1995.

BONAVIDES, Paulo. Curso de Direito Constitucional. 11. ed. São Paulo: Malheiros, 2001. 
BUARQUE DE HOLANDA, Aurélio Ferreira. Novo dicionário da Língua Portuguesa. 1. ed., 13 impressão. Rio de Janeiro: Nova Fronteira.

COELHO, Luis Fernando. Lógica Jurídica e Interpretação das Leis. 2. ed. Rio de Janeiro: Forense, 1981.

CAETANO, Geraldo; RILLA, José. Historia Contemporânea del Uruguay. 3. ed. Uruguay: Claeh, 2006.

CANÇADO TRINDADE, Otávio A. D. O MERCOSUL no Direito Brasileiro. Belo Horizonte: Del Rey, 2006.

CAMPANHOLE, Adriano; CAMPANHOLE, Hilton. Todas as Constituições do Brasil. São Paulo: Atlas, 1971.

CAMPOS, Lauro. A crise completa - A Economia Política do Não. São Paulo: Bomtempo, 2001.

CANOTILHO, J. J. Gomes. Direito Constitucional e Teoria da Constituição. 4. ed. Coimbra: Almedina, 2000.

CARNOY, Martin. Estado e a Teoria Política. 7. ed. Campinas: Papirus, 2001.

CARONE, Edgard. O Estado Novo (1937-1945). Rio de Janeiro: Difel, 1976.

CARLUCI, José Lence. Uma Introdução ao Direito Aduaneiro. São Paulo: Aduaneiras, 1997.

CARVALHO, Olímpio Ferraz de. Sistema parlamentar: história constitucional e politica. São Paulo: Piratininga, 1933. 
CASTRO, Therezinha de. História da Civilização Brasileira. Rio Janeiro: Capemi, 1982.

CHÂTELET, François; PISIER-KOUCHNER, Évelyne. As Concepções Políticas do Século XX, História do Pensamento Político. Rio de Janeiro: Zahar, 1983.

CHAVES, Julio César. Compendio de Historia Paraguaya. Asunción: Librería El Lector, 1998.

CLÉVE, Clèmerson Merlin. Atividade Legislativa do Poder Executivo. 2. ed. São Paulo: RT, 2000.

COOLEY, Thomas M. Princípios Gerais de Direito Constitucional nos Estados Unidos da América. Campinas: Russell, 2002.

CREVELD, Martin van. Ascensão e declínio do Estado. São Paulo: Martins Fontes, 2004.

DALLARI, Dalmo de Abreu. Elementos de Teoria Geral do Estado. 19. ed. São Paulo: Saraiva, 1995.

D'ANGELIS, Wagner Rocha. MERCOSUL - Da Intergovernabilidade à Supranacionalidade. Curitiba: Juruá, 2001.

DELLASOPPA, Emilio. Ao inimigo, nem justiça - violência política na Argentina 1943-1983. São Paulo: Hucitec, 1998.

DONGHI, Halperin. História da América Latina. Rio de Janeiro: Paz e Terra, 1975.

FAORO, Raymundo. Os Donos do Poder. 10. ed. São Paulo: Globo, 2000. v. II. 
FAUSTO, Boris; DEVOTO, Fernando. Brasil e Argentina - Um ensaio de história comparada (1950-2002). São Paulo: Ed. 34, 2004.

FINER, Samuel E. Governo Comparado. Brasília: UnB, 1981.

FOUCAULT, Michel. Em Defesa da Sociedade. São Paulo: Martins Fontes, 2002.

FRAGA, Mirtô. O Conflito entre Tratado Internacional e Norma de Direito Interno. Rio de Janeiro: Forense, 1998.

FURTADO, Celso. A Economia Latino Americana. 2. ed. São Paulo: Nacional, 1978.

GARCIA JÚNIOR, Armando Álvares. ALCA - A Área de Livre Comércio das Américas. São Paulo: Aduaneiras, 1999.

GOMES, Eduardo Biacchi. Blocos Econômicos - Solução de Controvérsias, 2. ed. Curitiba: Juruá, 2005.

GONÇALVES FERREIRA FILHO, Manoel. Curso de Direito Constitucional. 9. ed. São Paulo: Saraiva, 1980.

HABERMAS, Jürgen. Direito e Democracia - Entre a Factividade e Validade. Rio de Janeiro: Tempo Universitário, 1994. v. II.

HAGE, José Alexandre A. As Relações Diplomáticas entre Argentina e Brasil no MERCOSUL - princípios de hegemonia, dependência e interesse nacional no Tratado de Assunção. Curitiba: Juruá, 2004.

HAMBLOCH, Ernest. Sua Majestade o Presidente do Brasil - Um Estudo do Brasil constitucional (1889-1934). Brasília: UnB, 1981. v. 13. Coleção Temas Brasileiros. 
HAMILTON, Alexander et alii. O Federalista. Campinas: Russell, 2003.

HOBSBAWN, Eric. Era dos Extremos. O breve século XX, 1914-1991. São Paulo: Companhia das Letras, 1997.

IANNI, Octávio. A Formação do Estado Populista na América Latina. 2. ed. São Paulo: Ática, 1989.

JARÁ GOIRIS, Fabio Aníbal. Autoritarismo e Democracia no Paraguai Contemporâneo. Paraná: UFPR, 2000.

LAMBERT, Jacques. Os dois Brasis. São Paulo: Nacional, 1971.

LOCKE, John. Os Pensadores. 2. ed. São Paulo: Abril, 1983.

LUNA, Félix. Breve Historia de los Argentinos. Buenos Aires: Planeta, 1997. Argentina: de Perón a Lanusse (1943-1973). Rio de Janeiro: Civilização Brasileira, 1974.

LUXEMBURG, Rosa. A acumulação do capital. 2. ed. São Paulo: Nova Cultural, 1985.

KAPLAN, Marcos T. Formação do Estado Nacional. Rio de Janeiro: Eldorado, 1974.

KENNEDY, Paul. Ascensão e Queda das Grandes Potências. 3. ed. Rio de Janeiro: Campus, 1988.

MAGALHÃES, José Carlos de. Direito Internacional Econômico. Curitiba: Juruá, 2005. 
MALUF, Sahid. Teoria Geral do Estado. 11. ed. São Paulo: Sugestões Literárias, 1980.

MELLO, Celso de Albuquerque. Curso de Direito Internacional Público. 13. ed. Rio de Janeiro: Renovar, 2001. v. I.

Direito Internacional Econômico. Rio de Janeiro: Renovar, 1993.

MENEZES, Wagner. Direito Internacional na América Latina. Curitiba: Juruá, 2007.

MIRANDA, Jorge. Manual de Direito Constitucional - Preliminares o Estado e os Sistemas Constitucionais. 6. ed. Coimbra : Coimbra, 1997. t. I.

MONINELLI, N. Guillermo et alli. Congreso, Presidência y Justicia em Argentina, Buenos Aires: Temas, 1999.

MONTESQUIEU. Do Espírito das Leis. 3. ed. São Paulo: Abril, 1985.

MORAES, Ceres. Paraguai - A consolidação da ditadura de Stroessner 1954/63. Porto Alegre: EdiPUCRS, 2000.

MORRIS, Richard B. Documentos Básicos da História dos Estados Unidos. Rio de Janeiro: Fundo de Cultura, 1964.

MORAZÉ, Charles. A lógica da história. São Paulo: Difusão Européia do Livro, 1970.

MONIZ BANDEIRA, Luiz Alberto. Estado Nacional e Política Internacional na América Latina. 2. ed. São Paulo: Ensaio, 1995.

OLIVEIRA, Odete Maria de. Os descaminhos do Brasil nuclear. ljuí: Unijuí, 1999. 
União Européia: Processos de Integração e Mutação. Curitiba: Juruá, 1999.

OHMAE, Kenichi. O fim do Estado-nação. Rio de Janeiro: Campus; São Paulo: Publifolha, 1999.

PABST, Haroldo. MERCOSUL - Direito da Integração. Rio Janeiro: Forense, 1997.

PADOVER, Saul K. A Constituição viva dos Estados Unidos. São Paulo: Ibrasa, 1987.

PAREDES, Roberto; VARELA, Liz. Los Carlos - Historia del Derrocamiento de Alfredo Stroessner. Asunción: Ser Vilibro, 2005.

PAUPÉRIO, Machado. Presidencialismo, Parlamentarismo e Governo Colegial. Rio de Janeiro: Revista Forense, 1956.

PETRAS, James. No fio da navalha - Os Fundamentos do neoliberalismo. 2. ed. São Paulo: Xamã, 1998.

PILLA, Raul. Perfis Parlamentares, n. 16, Brasília, Câmara dos Deputados, 1980. RESQUIN, Francisco I. La Guerra del Paraguay contra la Triple Alianza. Asunción: El Lector, 1996.

ROMERO, Luis Alberto. História contemporânea da Argentina. Rio de Janeiro: Zahar, 2006.

ROUQUIÉ, Alain. O Extremo-Ocidente, Introdução à América Latina. São Paulo, Edusp, 1991.

O Estado Militar na América Latina. São Paulo: Alfa-Ômega, 1984. 
Poder militar y sociedad política em la Argentina. Buenos Aires: Emecé, 1978. v. I-II.

RUSSELL, Bertrand. O Poder. Rio de Janeiro: Zahar, 1979.

SÁNCHES, Luis Agesta. Curso de Derecho Constitucional Comparado. 7. ed. Madrid: Universidad Complutense de Madrid, 1980.

SCHAPOSNIK, Eduardo. As Teorias da Integração e o MERCOSUL Estratégias. Florianópolis: UFSC, 1997.

SEITENFUS, Ricardo. Manual das Relações Internacionais. 2. ed. Porto Alegre: Livraria do Advogado, 2000.

. O Brasil de Getúlio Vargas e a Formação dos Blocos 1930-1942. São Paulo: Nacional, 1985.

SEITENFUS, Ricardo; VENTURA, Deisy. Introdução ao Direito Internacional Público. Porto Alegre: Livraria do Advogado, 1999.

SILVA, Hélio. O Primeiro Século da República. Rio de Janeiro: Jorge Zahar, 1987. . Nasce a República. São Paulo: Três, 1975. v. I. Coleção História da República Brasileira.

SILVA, José Afonso da. Curso de Direito Constitucional Positivo. 19. ed. São Paulo: Malheiros, 2000.

SILVA, De Plácido e. Vocabulário Jurídico. São Paulo: Forense, 1963. v. IV.

STEVENS, Ellis C. Sources de la constitution des etats-unis. Tradução de Louis Vossion. Paris : Guillaumin, 1897. 
TORRES, João Camillo de Oliveira. Cartilha do Parlamentarismo. Belo Horizonte: Itatiaia, 1962.

TOYNBEE, Arnold. A Humanidade e a Mãe-Terra, Uma história narrativa do Mundo. 2. ed. Rio de Janeiro: Guanabara, 1987.

VENTURA, Deisy. Assimetrias entre o MERCosul e a União Européia. São Paulo: Manole, 2003.

A ordem jurídica do MERcosUL. Porto Alegre: Livraria do Advogado, 1996.

VEIGA GARCIA, Emanuel da. As Duas Argentinas. São Paulo: Ática, 1990.

VIANA, Francisco. Argentina - Civilização e Barbárie. São Paulo: Atual, 1991.

WACHOWICZ, Marcos. Propriedade Intelectual do Software \& Revolução da Tecnologia da Informação. Curitiba: Juruá, 2004.

Poder Constituinte e Transição Constitucional - Perspectiva HistóricoConstitucional. Curitiba: Juruá, 2000.

WATSON, Adam. A evolução da sociedade internacional. Brasília: UnB, 2004.

WINTER, Luís Alexandre Carta. A crise do modelo presidencialista no âmbito do MERCOSUL. Curitiba: Juruá, 2002.

2. Artigos em periódicos e capítulos de livros

ALMEIDA, Paulo Roberto de. Trajetória do MERCOSUL em sua primeira década (1991-2001: uma avaliação política a partir do Brasil). In: PIMENTEL, Luiz Otávio 
(Org.). Direito da Integração - Estudos em homenagem a Werter R. Faria. Curitiba: Juruá, 2001. v. II.

. O Brasil e o Futuro do MERCOSUL: Dilemas e Opções. In: CASELLA, Paulo et alii (Coords.). MERCOSUL: Integração Regional e Globalização. Rio de Janeiro: Renovar, 2000.

ALZAMORA, Carlos. La crisis y la capacidad de acción latinoamericana. Revista de la Integración Latino Americana, n. 105, set. 1985.

ANDERSON, Perry. Balanço do Neoliberalismo. In: Pós-Neoliberalismo: as políticas sociais e o Estado democrático. Rio de Janeiro: Paz e Terra, 1995.

BALASSA, Bela. À Procura de uma Integração Econômica. In: WIONCZEK, S. Miguel (Org.). A Integração Econômica da América Latina. Rio de Janeiro: Cruzeiro, 1966.

CACCIAMALI, Maria Cristina. Liberalización Económica y Derechos Fundamentales en el Trabajo en América Latina. In: Los Desafíos de la Política Social en América Latina. Caracas: Garcia \& Hijo, 2002.

CANUTO, Otaviano. "O Pós-Consenso de Washington" - Passagem de Stiglitz pelo Brasil. O Estado de S. Paulo, 28.07.1998.

CELLI JÚNIOR, Umberto. Teoria Geral da Integração: Em Busca de um Modelo Alternativo. In: MERCADANTE, Araminta (Org. et alii). Blocos Econômicos e Integração na América Latina, África e Ásia. Curitiba: Juruá, 2006. 
DORATIOTO, Francisco Fernando Monteoliva. Formação dos Estados Nacionais e expansão do capitalismo no século XIX. In: História do Cone Sul. Brasília: UnB, 1998.

DREIFUSS, René. Os códigos do admirável mundo novo. Lições de Mestres. Rio de Janeiro: Campus, 1998.

FURTADO, Celso. Desenvolvimento e subdesenvolvimento. In: BIELSCHOWSKY, Ricardo (Org.). Cinqüenta anos de pensamento na CEPAL. Rio de Janeiro: Record, 2000.

GRIMSOM, Alejandro. Vivências do Estado como Alteridade. In: FRIGERIO, Alejandro; RIBEIRO, Gustavo Lins (Orgs.). Argentinos e Brasileiros. Petrópolis: Vozes, 2002.

LOVE, Joseph. A Revolução de 30 e o Regionalismo Gaúcho. Conferência. SIMPÓSIO SOBRE A REVOLUÇÃO DE 30. 1980. Porto Alegre: UFRS/Erus, 1983.

MONIZ BANDEIRA, Luiz Alberto. As relações regionais no Cone Sul: iniciativas de integração. In: CERVO, Amado Luiz; RAPOPORT, Mário (Orgs.). História do Cone Sul. Brasília: UnB, 1998.

MOREIRA, ADRIANO et alii. Legado Político do Ocidente (O Homem e o Estado), Lisboa, 1988.

MOURA, Gerson. A Revolução de 1930 e a Política Externa Brasileira: Ruptura ou Continuidade? In: A Revolução de 30 - Seminário Internacional. Brasília: UnB, 1982.

NOVAES, Adalto. A invenção e a crise do Estado-Nação. In: A crise do EstadoNação. Rio de Janeiro: Civilização Brasileira, 2003. 
PIMENTEL, Luiz Otávio. MERCOSUL no Cenário Internacional, Direito e Sociedade. Curitiba, Juruá, 1998. v. II.

ROJO, Raúl Enrique. El Sistema Político Argentino. In: TAVARES, José Antônio Giusti; ROJO, Raúl Enrique (Orgs.). Instituições Políticas Comparadas dos Países do MERCOSUL. Rio de Janeiro: Fundação Getúlio Vargas, 1998.

SANTOS, Ana Maria dos. América Latina: dependência, ditaduras e guerrilhas. In: REIS, Daniel Aarão Filho (Org.). O século $X X, 0$ Tempo das Dúvidas - Do declínio das utopias às globalizações. Rio de Janeiro: Civilização Brasileira, 2000. v. III.

SENNE DE MORAIS, Márcio, Discurso de Jospin tem razões internas e externas. Folha de S. Paulo, 29 maio 2001.

SIERRA, Gerónimo de. Sistema político, sistema de partidos y régimen electoral en el Uruguay. In: TAVARES, José Antônio Giusti; ROJO, Raúl Enrique (Orgs.). Instituições Políticas Comparadas dos Países do MERCOSUL. Rio de Janeiro: Fundação Getúlio Vargas, 1998.

SIMÓN, José Luis. Sistema político, Estado y sociedad en el Paraguay del autoritarismo contemporáneo y en el de la transición y la integración democrática. In: TAVARES, José Antônio Giusti; ROJO, Raúl Enrique (Orgs.). Instituições Políticas Comparadas dos Países do MERCosUL. Rio de Janeiro: Fundação Getúlio Vargas, 1998.

TAVARES, José Antônio Giusti. O sistema político Brasileiro. In: ROJO, Raúl Enrique (Orgs.). Instituições Políticas Comparadas dos Países do MERCOSUL. Rio de Janeiro: Fundação Getúlio Vargas, 1998. 
TAVARES, Maria da Conceição. Auge e declínio do processo de substituição de importações no Brasil. In: BIELSCHOWSKY, Ricardo (Org.). Cinqüenta anos de pensamento na CEPAL. Rio de Janeiro: Record, 2000.

TULIS, Jeffrey. As duas Presidências Constitucionais. In: NELSON, Michel (Org.). A Presidência e o Sistema Político - Política Norte-Americana Hoje. São Paulo: Alfa-ômega, 1985.

VERÇOSA, Haroldo Malheiros Duclerc. Os regimes políticos e jurídicos dos Bancos Centrais. In: SZTAJN, Raquel (Coord.). Direito da Integração. São Paulo: Universidade Cidade de São Paulo, 2001.

WINTER, Luís Alexandre Carta. A construção histórica do conceito de Soberania. In: Anais do V Congresso de Direito Internacional. Curitiba: Juruá, 2007. v. X.

WINTER, Luís Alexandre Carta. A América Latina e a Globalização. In: WINTER, Luís Alexandre Carta. RAMOS, Heidy Rodriguez (Org.). IBERO-AMÉRICA Os Desafios da Integração da América Latina e sua Inserção no Sistema Internacional Curitiba: Juruá, 2006.

WINTER, Luís Alexandre Carta. WACHOWICZ, Marcos. A construção de uma identidade. In: Anais do COMPEDI. Belo Horizonte, 2007.

\section{Documentos e documento on line}

Constituição Brasileira. Curitiba: Juruá, 2007.

Disponível em: <http://www.mre.gov.br/index>. Acesso em: 27 jan. 2008.

Disponível em: <www.mercosur.int/msweb/portal>. Acesso em: 21 a 24 jan. 2008. 
Disponível em: <http://www.diputados.gov.ar/>. Acesso em: 25 jan. 2008.

Disponível em: <http://pdba.georgetown.edu/Constitutions/Paraguay/para1992.html> Acesso em: 25 jan. 2008.

Disponível em: <http://www.rau.edu.uy/uruguay/const97-7.11.htm>. Acesso em: 25 jan. 2008.

Disponível em: <http://www.rau.edu.uy/uruguay/const97-7.11.htm>. Acesso em: 25 jan. 2008.

\section{Artigos e obras on line}

Disponível em: <http://www.dominiopublico.mec.gov.br/pesquisa> .

Disponível em: <http://educaterra.terra.com.br/voltaire/mundo/segunda_guerra.htm>. Acesso em: 26 jan. 2008.

Disponível em: <http://ahorainfo.com.ar/?p=6265> Acesso em: 08 fev. 2008. 